$$
\text { UNIVERSIDADE DE SÃO PAULO }
$$

FACULDADE DE FILOSOFIA, LETRAS E CIÊNCIAS HUMANAS DEPARTAMENTO DE LETRAS CLÁSSICAS E VERNÁCULAS PROGRAMA DE PÓS-GRADUAÇÃO EM LETRAS CLÁSSICAS

SARA GONÇALVES DEVAI

ATOS DE PAULO E TECLA: ESTUDO E TRADUÇÃO

(versão corrigida)

Orientadora: Profa. Dra. Adriane da Silva Duarte

SÃO PAULO 
UNIVERSIDADE DE SÃO PAULO

FACULDADE DE FILOSOFIA, LETRAS E CIÊNCIAS HUMANAS

DEPARTAMENTO DE LETRAS CLÁSSICAS E VERNÁCULAS

PROGRAMA DE PÓS-GRADUAÇÃO EM LETRAS CLÁSSICAS

\section{ATOS DE PAULO E TECLA: ESTUDO E TRADUÇÃO}

(versão corrigida)

Sara Gonçalves Devai

Dissertação apresentada ao Programa de Pós-Graduação em Letras Clássicas do Departamento de Letras Clássicas e Vernáculas da Faculdade de Filosofia, Letras e Ciências Humanas da Universidade de São Paulo para a obtenção de título de Mestre em Letras.

Orientadora: Profa. Dra. Adriane da Silva Duarte

SÃO PAULO

2019 
Autorizo a reprodução e divulgação total ou parcial deste trabalho, por qualquer meio convencional ou eletrônico, para fins de estudo e pesquisa, desde que citada a fonte.

Catalogação na Publicação

Serviço de Biblioteca e Documentação

Faculdade de Filosofia, Letras e Ciências Humanas da Universidade de São Paulo

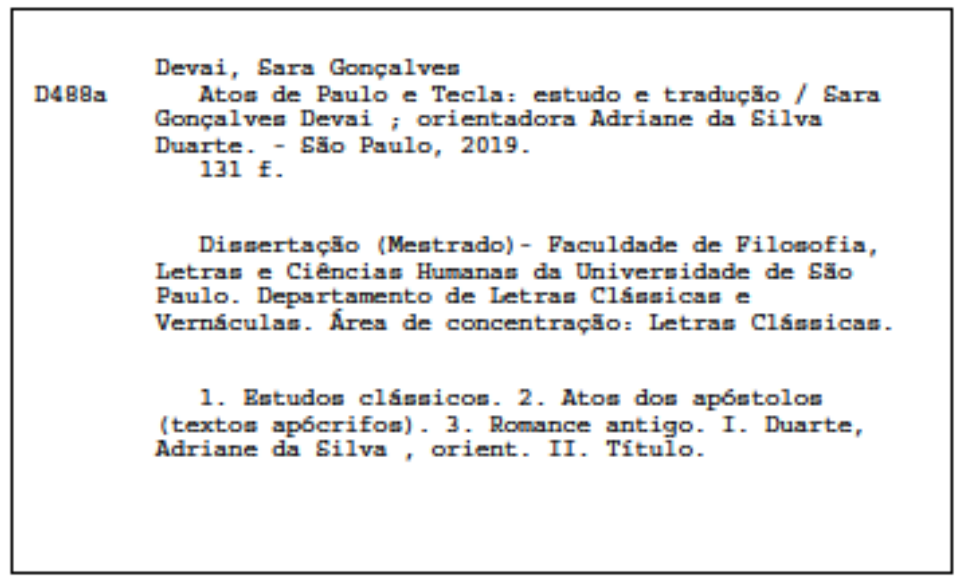


fflo h universidade de são paulo

FACULDADE DE FILOSOFIA, LETRAS E CIẼNCIAS HUMANAS

\section{ENTREGA DO EXEMPLAR CORRIGIDO DA DISSERTACÄO/TESE}

Termo de Ciência e Concordância do (a) orientador (a)

Nome do (a) aluno (a): Sara Gonçalves Devai

Data da defesa: $26 / 03 / 2019$

Nome do Prof, (a) orientador (a): Adriane da Silva Duarte

Nos termos da legislação vigente, declaro ESTAR CIENTE do conteúdo deste EXEMPLAR CORRIGIDO elaborado em atenção às sugestões dos membros da comissão Julgadora na sessão de defesa do trabalho, manifestando-me plenamente favorável ao seu encaminhamento e publicaçã́a no Portal Digiral de Teses da USP.

São Paulo, 15/05/2019

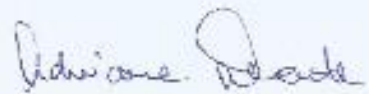

(Assinotura da (a) arientodar (a) 
Nome: Devai, Sara Gonçalves

Título: Atos de Paulo e Tecla: tradução e estudo

Dissertação apresentada ao Programa de Pós-Graduação em Letras Clássicas do Departamento de Letras Clássicas e Vernáculas da Faculdade de Filosofia, Letras e Ciências Humanas da Universidade de São Paulo para a obtenção de título de Mestre em Letras.

Aprovado em:

Banca Examinadora

Prof. Dr.:

Instituição:

Parecer:

Assinatura:

Prof. Dr:

Instituição:

Parecer:

Assinatura:

Prof. Dr.:

Instituição:

Parecer:

Assinatura: 


\section{AGRADECIMENTOS}

À Universidade de São Paulo e, particularmente, à equipe do Departamento de Letras Clássicas da FFLCH, incluindo professores e funcionários. Foi o trabalho comprometido de todos os seus membros que proporcionou a minha chegada até aqui. Espero retribuir à sociedade todo o investimento que essa instituição fez em minha pessoa. À Profa. Dra. Luise Marion Frenkel que deu valiosas contribuições na banca de qualificação e através de quem chegou as nossas mãos o texto grego de Atos de Paulo e Tecla (working in progress inédito), gentilmente cedido por J.-D. Kaestli. Ao Prof. Dr. Milton Torres pelas também preciosas orientações na banca de qualificação. Esse trabalho não seria o mesmo sem o aporte de vocês. À minha orientadora, a Profa. Dra. Adriane da Silva Duarte, por me apontar o caminho da pós-gradução, apresentar os rumos do trabalho, e proporcionar todo o apoio necessário, principalmente no estabelecimento do aparato crítico. Sempre oferecendo e exigindo o melhor, sempre disponível, generosa e com uma paciência admirável. Nunca poderei agradecer adequadamente. Ao amigo e irmão Bob Bell, pela atenção ágil e prestativa.

Aos meus pais, pela educação me deram e por moldarem as circunstâncias que construíram essa criatura que sou eu. Em particular a minha mãe, essa senhora humilde e de poucos estudos, mas de um amor tão incompreensível quanto grande. A sua abnegação e apoio devo todas as boas conquistas que alcancei até aqui. Sem a presença desse anjo em forma humana, minha vida teria tomado rumos que nem consigo imaginar. Mãe, o mérito deste trabalho é mais seu do que meu. Ao André, o esposo incrível, o grande incentivador, que nunca me permitiu desistir e que, juntamente com os queridos filhos, André e Andressa, ofereceu apoio incondicional, mesmo que isso significasse um alto preço em contratempos, renúncia e paciência. Portanto, este trabalho é nosso, querida família. Ele pertence à nossa equipe.

Àquele que providenciou tudo o que foi citado acima e infinitamente mais. Diante dEle me curvo e digo, usando as palavras de Paulo: “Graças a Deus que nos dá a vitória por meio de nosso Senhor Jesus Cristo" (1 Coríntios 15:57 - NVI). 


\section{RESUMO}

DEVAI, Sara Gonçalves. Atos de Paulo e Tecla: estudo e tradução. 2019. Dissertação (Mestrado em Letras Clássicas) - Faculdade de Filosofia, Letras e Ciências Humanas, Universidade de São Paulo, São Paulo, 2019.

Atos de Paulo e Tecla narra as provações e extraordinários livramentos experimentados por Tecla, uma jovem e bela virgem de Icônio, após tornar-se cristã através da pregação de Paulo. Provavelmente a obra foi composta em meados do século II, o que coincide com o auge da produção dos romances gregos e do florescimento da Segunda Sofística. Embora apresente importantes pontos de contato com o romance antigo e com a literatura cristã canônica, Atos de Paulo e Tecla também se diferencia consideravelmente destes, o que o coloca claramente em um grupo à parte. O objetivo deste trabalho é apresentar uma tradução do texto grego para o português juntamente com um estudo de suas relações com o romance antigo e uma análise de seu contexto.

PALAVRAS-CHAVE: Atos de Paulo e Tecla. Atos apócrifos dos apóstolos. Tecla. Paulo, romance grego antigo 


\section{ABSTRACT}

DEVAI, Sara Gonçalves. Acts of Paul and Thecla: study and translation. 2019. Dissertação (Mestrado em Letras Clássicas) - Faculdade de Filosofia, Letras e Ciências Humanas, Universidade de São Paulo, São Paulo, 2019.

The Acts of Paul and Thecla narrates the trials and extraordinary deliverance experienced by Thecla, a beautiful young virgin from Iconium, after she became a Christian by Paul's preaching. The work was composed in the middle of the second century, simultaneously with the peak of ancient Greek novel production and the flourishing of the Second Sophistic. Despite extensive similarities between the ancient novel, the canonical Christian literature, and The Acts of Paul and Thecla, the latter differs considerably from the other two. This dissertation includes the translation of this narrative from Greek to Portuguese, a study about its correlation with the ancient novel, as well as an analysis of its historical and literary context.

KEYWORDS: Acts of Paul and Thecla. Apocryphal acts of the apostles. Thecla. Ancient Greek Novel 


\section{LISTA DE ABREVIATURAS E SIGLAS}

AAA - Atos apócrifos dos apóstolos

AP - Atos de Paulo

APT - Atos de Paulo e Tecla

ALM 21 - Bíblia. Versão em português: Almeida Século 21.

ARA - Bíblia. Versão em português: Almeida Revista e Atualizada.

ARC - Bíblia. Versão em português: Almeida Revista e Corrigida.

CP - Cartas Pastorais (1 e 2 Timóteo, Tito)

DGP - Dicionário grego-português

DGRA - A Dictionary of Greek and Roman Antiquities

LGPNT - Léxico grego-português do Novo Testamento

LNTGP - Léxico do Novo Testamento - Grego/Português

LSJ - The Online Liddell-Scott-Jones Greek-English Lexicon

NTLH - Bíblia. Nova Tradução na Linguagem de Hoje.

NVI - Bíblia. Nova Versão Internacional.

NT - Novo Testamento

a. C. - antes de Cristo.

d. C. - depois de Cristo. 


\section{SUMÁRIO}

INTRODUÇÃO....................................................................................................................10

CAPÍTULO 1: Atos de Paulo e Tecla e seu contexto......................................................13

CAPÍTULO 2: Uma análise literária.............................................................................25

CAPÍTULO 3: Atos de Paulo e Tecla e o romance antigo...............................................44

CONSIDERAÇÕES FINAIS.........................................................................................64

TRADUÇÃO: ATOS DE PAULO E TECLA .............................................................66

REFERÊNCIAS BIBLIOGRÁFICAS.......................................................................103

APÊNDICE A............................................................................................114

APÊNDICE B................................................................................................129 


\title{
INTRODUÇÃO
}

\begin{abstract}
“Os Atos de Paulo e Tecla, então, não apenas testificam do poder da Palavra, mas também demonstram o poder de um texto"
\end{abstract}

(BREMMER, 1996, p. 59).

Avaliando a influência de Atos de Paulo e Tecla [doravante referido por APT] sobre as mulheres cristãs do século II e III d.C., Bremmer, nas palavras acima, atribui à obra o caráter de texto poderoso por ter sido capaz de suscitar no segmento feminino de comunidades cristãs primitivas (ou pelo menos em parte delas) a pretensão ao direito de pregar e batizar, despertando o zelo de líderes como Tertuliano (II-III d.C.), o apologista cristão. De fato, o pesquisador holandês não é o único a mostrar interesse nesse texto e notar sua importância. O número considerável de manuscritos sobreviventes em línguas antigas como grego, copta, latim, siríaco e armênio, assim como as referências em obras da Antiguidade Tardia, testemunham a larga difusão da mesma dentro do cristianismo, desde a Antiguidade até a Idade Média. ${ }^{1}$ E, se na modernidade seu texto não foi, digamos, tão popular, as aparições ocasionais mostram que não ficou de todo esquecido. ${ }^{2}$ Por fim, nos últimos dois séculos, o interesse acadêmico por essa narrativa vem gradualmente aumentando até que hoje há uma gama de publicações voltadas para os diversos aspectos da obra. ${ }^{3}$ São livros, artigos e verbetes em línguas como alemão, inglês, francês, italiano,

\footnotetext{
${ }^{1}$ A abundância de manuscritos é atestada por Barrier (2008, p. 7 a 9), que em sua tese sobre $A P T$ se serve de 24 testemunhas textuais em grego de $A P$ (que inclue $A P T$ ), 59 em latim, 4 em copta e 4 em siríaco (os manuscritos em armênio não estão enumerados); por Dunn (2006, p. xi), que cita 49 mss gregos de $A P T$ colecionados por Rordorf, assim como versões latinas, siríacas, armênias e coptas; e, por fim, Pervo afirma que há mais de 40 mss gregos disponíveis (2014, p. 59). O estudioso, após destacar a enorme quantidade de variantes em diversas línguas antigas, afirma que isto indica "no mínimo, que essa história experimentou consideráveis edições". E, ainda que os números apresentados por esses autores não coincidam, a abundância de manuscritos não deixa de ser notável.

${ }^{2} \mathrm{Na}$ listagem de Barrier, citada na nota acima, aparecem pelo menos duas testemunhas do século XII d.C. que foram publicadas em 1700. Para a história textual de APT, cf. BARRIER, 2008, p. 51-54.

${ }^{3}$ A bibliografia de Atos de Paulo recomendada pelo site topics.logos.com alcança quase 300 publicações, das quais pelo menos 49 apresentam o nome de Tecla no título, sem contar os que não mencionam a obra neles, mas abordam seus temas, como "Women, Tertullian and the Acts of Paul", de Stevan Davies. Embora desatualizada, essa lista é útil para fornecer um panorama dos estudos sobre a obra até 2012. Além dela, é possível encontrar boas fontes de pesquisa em outros sites, tais como: www.patrologia-lib.ru (que fornece o texto grego), actapauli.wordpress.com (com artigos e discussões sobre $A P$ ) e web.archive.org (que traz uma lista de publicações sobre Tecla, disponíveis na internet).
} 
espanhol e português que abordam temas tão variados quanto feminismo, ortodoxia (cristã), gênero literário, historicidade, erotismo, encratismo e fisiognomia.

No entanto, apesar de a obra ser relativamente conhecida entre os classicistas europeus e norte-americanos, no Brasil a oferta de material de pesquisa ainda é bastante acanhada. Embora Tecla, a protagonista da trama, seja relativamente conhecida no meio religioso, durante muito tempo o interesse por $A P T$ em si foi praticamente limitado aos cursos de teologia que têm maior interesse no cristianismo primitivo, ${ }^{4}$ sendo que nos estudos clássicos as pesquisas são ainda mais raras. ${ }^{5}$

Motivada por essa lacuna na investigação acadêmica brasileira (apontada por minha orientadora), além da atração exercida pela própria história, iniciei em 2016 os estudos no mestrado com o objetivo de oferecer uma tradução da obra diretamente do grego, a partir de uma compilação de edições que incorporaram avanços textuais mais recentes (com aparato crítico), acompanhada de estudos introdutórios de outros temas pertinentes, tais como sua ligação com a literatura cristã primitiva e com o romance antigo, além de uma análise literária.

Em setembro de 2017, quando a tradução e os primeiros esboços dos capítulos já estavam nas mãos da banca de qualificação, tomei conhecimento da recente publicação de Atos de Paulo e Tecla - A narrativa romanesca e o discurso sobre a imagem do apóstolo, de Cláudio da Chaga Soares. O livro consiste no trabalho de pesquisa do autor em sua dissertação para o mestrado em Ciências da Religião e, além do texto grego vertido para o português, oferece também um estudo sobre as relações entre o romance antigo e o discurso da literatura apócrifa, em especial os Atos Apócrifos dos Apóstolos [doravante referidos por AAA], somado a uma bem fundamentada pesquisa a respeito da linguagem utilizada em APT para analisar a imagem de Paulo.

Não é difícil observar que nossos trabalhos se sobrepõem em pelo menos dois pontos: a tradução de $A P T$ diretamente do grego para o português e a sua relação com o romance antigo. No entanto, apesar das similaridades, existem também diferenças de abordagem e estrutura, as quais poderão tornar mais ricas as investigações do público de língua portuguesa. Visto que nosso idioma carece bastante de estudos dos AAA e, em

\footnotetext{
${ }^{4}$ Periódicos como a Revista Bíblica Brasileira, a Orácula e a Revista de Interpretação Bíblica LatinoAmericana são exemplos de publicações acadêmicas que apresentam artigos relacionados a $A P T$.

${ }^{5}$ Por exemplo, em 2013 Ipiranga Junior publicou artigo analisando o páthos erotikhón em Atos de Paulo e Tecla. Desde 2016, os AAA são parte do corpus do projeto de pesquisa Prosa narrativa de ficção na Grécia antiga: romance e gêneros correlatos, na pós-graduação do Departamento de Letras Clássicas e Vernáculas da Universidade de São Paulo.
} 
particular, de $A P T$, há um largo espaço para que seus temas sejam desenvolvidos por aqui, especialmente porque as pesquisas sobre esses textos lançam nova luz a respeito de questões importantes tanto no estudo da literatura cristã primitiva quanto do romance antigo e muitos outros temas, os quais interessam a pesquisadores das mais diversas áreas. Portanto, assim como APT tem despertado a atenção dos meios acadêmicos no exterior, que mais e mais pesquisadores lusófonos se debrucem sobre essa obra e outras semelhantes, trazendo ao público de nossa língua pátria as inúmeras possibilidades que os estudiosos estrangeiros já começaram a descobrir. E se Atos de Paulo e Tecla realmente demonstra o poder de um texto, como afirma Bremmer, a academia só tem a ganhar com a investigação da obra.

A fim de cumprir a proposta citada acima, no terceiro parágrafo, decidi estruturar este trabalho em quatro capítulos. No primeiro deles, apresento Atos de Paulo e Tecla e o situo em seu contexto aproximado de produção. Para isso exponho um breve apanhado da literatura cristã dos dois primeiros séculos de nossa era, sua origem e evolução, juntamente com as condições históricas e culturais que ajudaram a moldá-la. O segundo capítulo se dedica a analisar a obra literariamente, procurando perceber as estratégias utilizadas pelo autor para elaborar seu texto e suas consequências na compreensão do mesmo. Longe de pretender uma investigação profunda e cabal, a proposta é fornecer ao leitor subsídios para uma leitura mais proveitosa e abrir espaço para mais discussões. Já no terceiro capítulo procuro demonstrar as ligações de $A P T$ com o romance antigo, partindo de um estudo sobre o gênero romanesco e o vínculo deste com os AAA, nos quais se encaixa nosso texto de estudo. Por fim, entrego a tradução, acompanhada do texto grego compilado e do aparato, no quarto capítulo. No apêndice, ofereço algumas informações que julgo interessantes para o leitor, além de recursos visuais que ajudem a conhecer e entender melhor a obra. Todas as traduções da bibliografia em inglês e espanhol são minhas. 


\section{CAPÍTULO 1:}

\section{Atos de Paulo e Tecla e seu contexto}

"E Tecla, tendo se erguido, disse a Paulo: "Eu vou para Icônio". E Paulo disse: "Vá e ensine a Palavra de Deus." (Atos de Paulo e Tecla, seção 41). ${ }^{6}$

Entre o final do século II e o início do século III d.C., Tertuliano escreve $D e$ Baptismo, um tratado sobre a doutrina do batismo. No capítulo 17.5, falando sobre quem tem o direito de administrar esse rito (bispos, sacerdotes, diáconos e, na falta destes, homens leigos), o apologista cristão de Cartago opõe-se vigorosamente a que a mulher o faça. Como argumento, acusa de ilegítimo o texto que é usado para apoiar essa ideia. Trata-se de Atos de Paulo, mais precisamente do trecho conhecido como Atos de Paulo e Tecla, composição que narra as aventuras de uma bela jovem convertida à fé cristã pela pregação do apóstolo e que, depois de ser salva miraculosamente do martírio por duas vezes, recebe deste a autorização para pregar, dedicando-se a essa atividade e às curas até o fim de sua vida. Eis as palavras de Tertuliano ${ }^{7}$ :

\footnotetext{
"Mas se certos Atos de Paulo, os quais são falsamente assim chamados, reivindicam o exemplo de Tecla para permitir que as mulheres ensinem e batizem, saibam os homens que, na Ásia, o presbítero que compilou esse documento, pensando por si mesmo em aumentar a reputação de Paulo, foi descoberto, e embora professasse tê-lo feito por amor a Paulo, foi deposto de sua posição. Como poderíamos acreditar que Paulo daria autoridade às mulheres para ensinar e batizar, quando ele não permitia até mesmo que elas se instruíssem? 'Que fiquem em silêncio - ele disse - e que consultem a seus maridos em casa"”. (De Baptismo, 17.5).
}

\footnotetext{
${ }^{6}$ As citações de $A P T$ são de minha tradução.

Traduzido a partir da versão em inglês de EVANS, de 1964, disponível em http://www.tertullian.org/articles/evans_bapt/evans_bapt text trans.htm (consultado em 04/01/2019). Para outras versões em latim e inglês, cf. HILHORST, 1996, p. 150 -163. Além dessas, acho bastante relevante a tradução apresentada por Davis (2001, p. 14) do trecho "presbyterum qui eam scripturam construxit, quasi titulo Pauli de suo cumulans". Ao invés de "the presbyter who compiled that document, thinking to add of his own to Paul's reputation" (a tradução de Evans), ele propõe: "the man "put together (contruere) that book, amassing (cumulare) it from his own materials [...]". Desta forma fica exposto o significado das duas palavras latinas que o estudioso aponta como a evidência interna para a hipótese de que $A P T$ seja uma compilação de tradições mais antigas. Ou seja, o tal presbítero teria composto $A P$, reunindo materiais que ele já possuía antes.
} 
Nesse trecho de sua obra, Tertuliano escreve um texto apologético no qual se opõe a outro, narrativo, apoiando sua argumentação em um terceiro, lido e conhecido de seus leitores: a primeira carta de Paulo aos Coríntios. ${ }^{8}$ Ou seja, à época do autor cartaginês o registro escrito, em diversos gêneros, era um meio amplamente utilizado pelos diferentes ramos do cristianismo com os mais variados objetivos, formando uma literatura que pode ser reconhecida como cristã. Mas, desde quando esse fenômeno chamado literatura cristã passou a existir? Qual era o cenário cultural e histórico? Que fatos moldaram a produção literária dos seguidores de Jesus Cristo?

Em meados do ano 27 de nossa era, surge na Galileia um pregador itinerante chamado Jesus que se dirige ao povo judeu (e eventualmente às nações vizinhas) com uma mensagem muito clara: ele era o Filho de Deus, ${ }^{9}$ o esperado Messias, ${ }^{10}$ prometido pelo Criador, enviado ao mundo para resgatar a humanidade do pecado e da morte e cumprir as profecias longamente aguardadas $;{ }^{11}$ os que cressem nele teriam o perdão dos pecados e a garantia da vida eterna. ${ }^{12}$ Nesse momento, seu ensino é basicamente oral e circunscrito à Palestina. Após sua morte, os discípulos, impulsionados pela crença na ressurreição de seu mestre, ${ }^{13}$ encarregam-se de transmitir a mensagem de Jesus e expandir seu alcance. Santos (2012, p. 14) vê aí o início de uma institucionalização da igreja, "com um grupo de líderes e as primeiras ordenanças".

O mesmo autor (SANTOS, 2012, p. 15), discorrendo acerca dos efeitos que a expansão da mensagem cristã trouxe sobre ela mesma, propõe quatro momentos definidores de suas características, com personalidades que, segundo ele, representariam esses períodos. ${ }^{14}$ A proposta de Santos pode ser sintetizada como se segue: 1 . O ensino pessoal de Jesus; 2. A disseminação da mensagem pelos discípulos, primeiramente em

\footnotetext{
${ }^{8}$ Cf. 1 Coríntios 14:35.

9 "Porque a vontade de meu Pai é que todo o que olhar para o Filho e nele crer tenha a vida eterna, e eu o ressuscitarei no último dia" (João 6:40 - NVI).

10 "Disse a mulher: 'Eu sei que o Messias (chamado Cristo) está para vir. Quando ele vier, explicará tudo para nós'. Então Jesus declarou: 'Eu sou o Messias! Eu, que estou falando com você' ”. (João 4:25 e 26 $\mathrm{ARC})$

11 Mateus 5:17; Lucas 4:15-21.

12 "Porque Deus amou o mundo de tal maneira que deu o seu Filho unigênito, para que todo aquele que nele crê não pereça, mas tenha a vida eterna. Porque Deus enviou o seu Filho ao mundo, não para que condenasse o mundo, mas para que o mundo fosse salvo por ele" (João 3:16-17 - ARC). Cf. João 12:47.

${ }^{13}$ Cf. Atos 2:32; 3:15; 4:10; 5:30; 10:40, 41; 13:30, 37; 17:3, 31; 26:23. Todos esses textos mostram os apóstolos pregando acerca da ressurreição de Cristo em diferentes lugares e circunstâncias. Somados às passagens das epístolas que abordam o tema, se tornam em respeitável evidência de que este ocupava um lugar de destaque na pregação apostólica.

14 Obviamente, diversas periodizações podem ser concebidas, nas quais outros personagens do cenário cristão dos dois primeiros séculos também recebam destaque. No entanto, a de Santos me parece suficiente para a compreensão da gênese e desenvolvimento da literatura cristã primitiva, já que não é nosso objetivo fazer um exame minucioso dela, mas apresentar o panorama literário onde Atos de Paulo e Tecla se insere.
} 
direção aos judeus e, depois, dirigida aos gentios (povos politeístas); 3. As atividades dos Pais Apostólicos; 4. Os labores dos Pais Apologistas.

O primeiro estágio, o nascimento do cristianismo, é produto do ensino pessoal de Jesus (iniciado em 27 d.C), transmitido basicamente de forma oral. Após sua morte (30 d.C), segue-se o segundo momento, fruto do trabalho dos discípulos em disseminar a mensagem cristã, primeiramente dirigindo-se aos judeus e depois aos gentios. Durante esse período, a transmissão oral continua predominante, pois os apóstolos viajam da Palestina para outras regiões, estabelecendo novas comunidades de cristãos através de pregações e disputas verbais. No entanto, paralela à tradição oral, bem estabelecida, a produção literária cristã começa a aparecer, aumentando gradualmente o número de obras e de gêneros. É quando surgem os textos que comporão mais tarde o cânon do Novo Testamento $^{15}$ (além de outros que ficaram de fora, como a primeira carta de Clemente ${ }^{16}$ ). E para alguns estudiosos atuais é possível perceber traços da literatura helenística nas obras cristãs deste período, mostrando que a proximidade entre ambas já exerce sua influência ${ }^{17}$. O terceiro vai do final do século I a meados do século II e traz as produções dos Pais Apostólicos (homens que provavelmente tiveram contato direto com os apóstolos ou com discípulos destes). ${ }^{18}$ Para Santos (2012, p. 15), essa época se caracteriza por uma "reformulação da mensagem cristã", devida à intensa interação com os gentios, começando a "cristalizar a mesclagem entre os aspectos judaicos no cristianismo e as ideias helênicas". ${ }^{19}$ Por fim, na era dos Pais Apologistas (século II) o cristianismo se

\footnotetext{
${ }^{15}$ Segundo Paroschi (2012, p. 85), "as evidências sugerem que os autógrafos neotestamentários começaram a ser produzidos ainda no período apostólico".

${ }^{16}$ Sobre a datação cf. VIELHAUBER, 2005, p. 678.

${ }^{17}$ Um exemplo é o proêmio do Evangelho Segundo Lucas, que, para Vielhauber (cf. 2005, p. 398), mostra sua postura de historiador e seu conhecimento das convenções literárias da historiografia. Stanley K. Stowers (1988, p. 80-82) aponta várias passagens semelhante às diatribes nas cartas de Paulo aos Romanos e aos Coríntios, como também na carta de Tiago. John L. White (1998, p. 101) encontra diversos elementos da epistolografia helenística nas cartas do Novo Testamento. Já no campo doutrinário, a proximidade (cristianismo/ povos politeístas) leva ao rompimento com um rito fundamental do judaísmo: a circuncisão. Devido à grande adesão de gentios, a liderança da igreja reunida em Jerusalém (ca 49 d.C.) decide, depois de debates intensos, não exigir essa prática dos crentes advindos de outras nações, dando a entender que não era necessário se tornar um judeu para ser um cristão. Tal decisão é registrada em uma carta e enviada à igreja de Antioquia da Síria através de Paulo e Barnabé, acompanhados de mais duas testemunhas (Atos 15:22-29), num exemplo do uso da escrita pela igreja em documentos oficiais não muito tempo depois de seu início.

18 Tradicionalmente Clemente, Irineu e Policarpo (Apostolic fathers, Catholic Encyclopedia. < http://www.newadvent.org/cathen/06001a.htm\#A> Consultada em 30/10/2018),

${ }^{19}$ A respeito da influência helênica no cristianismo dos dois primeiros séculos, Santos observa que os cristãos formavam "um grupo que, em sua maioria, falava e escrevia em grego, utilizava gêneros e estilos gregos, se servia de ideias da filosofia grega, procurava adequar sua mensagem aos 'esquemas mentais' dos helênicos" (2012, p. 61). Para uma visão discordante, cf. SPINELLI, Miguel. Helenização e recriação de sentidos. Caxias do Sul: EDUCS, 2015.
} 
apresenta multifacetado. São diversos segmentos com suas crenças peculiares, cada qual reivindicando para si a designação de cristianismo verdadeiro. ${ }^{20}$

Nos dois primeiros séculos de nossa era, simultaneamente a todo esse processo no meio cristão, ocorria uma abundante produção literária nos círculos cultos do império, com produções nos mais variados campos: filosofia, oratória, poesia, narrativas de ficção em prosa, história etc. ${ }^{21}$ As escolas filosóficas atraíam seus seguidores e o campo do pensamento apresentava grupos tão distintos quanto os estoicos, os neoplatonistas e os epicuristas.

O império era romano, mas a língua grega era muito disseminada e os cidadãos bilíngues não eram incomuns. Por isso os textos cristãos escritos em grego podiam ser lidos em todo o império, o que ajudou bastante sua dispersão. As estradas romanas, que facilitavam a movimentação rápida dos exércitos imperiais também favoreceram as viagens dos propagadores do cristianismo, com destaque para Paulo de Tarso, bem como os de outras correntes de pensamento, a sofística entre elas, a qual floresceu em diversas das cidades visitadas por Paulo e outros pregadores cristãos (Atenas, Éfeso, Esmirna). ${ }^{22}$

Visto a princípio como uma seita judaica, em suas primeiras décadas o cristianismo se espalhou pelo império inicialmente sob a indiferença de Roma, ${ }^{23}$ sendo que sua maior oposição vinha do judaísmo - da qual resultaram a morte de Estevão (Atos 7:59) e Tiago, filho de Zebedeu (Atos 12:2). Esse quadro mudou a partir do ano 64 d.C, quando surgiram as perseguições promovidas pelo Estado, a primeira delas praticada por Nero após o incêndio de Roma, ocasião em que os apóstolos Paulo e Pedro sofreram o martírio. Segundo Tácito, o imperador desviou de si as suspeitas de ter ordenado o sinistro, acusando aquela que o historiador identifica como a "classe odiada por suas abominações, chamada de cristãos pelo populacho" (Anais, XV, 44). Na mesma página, sua descrição dos suplícios infligidos aos acusados revela a severidade das punições:

\footnotetext{
${ }^{20}$ Podemos citar o montanismo, o ebionismo, o marcionismo, o gnosticismo e o encratismo, entre outros segmentos descritos por Eusébio em sua História Eclesiástica (século IV d.C).

${ }^{21}$ Como exemplo da literatura produzida nos séculos I e II podemos citar obras tão diversas quanto o Encheiridion de Epicteto, de Arriano; Institutio Oratoria, de Quintiliano; Ars Amatoria, de Ovídio; os Anais, de Tácito; os diálogos de Sêneca; o Satiricon, de Petrônio, as biografias escritas por Plutarco, A Vida de Apolônio de Tiana, de Filóstrato e, os textos hoje conhecidos como romances antigos, Quéreas e Calírroe, Leucipe e Clitofonte e Lucio ou o Asno, entre muitos outros.

22 “A cultura retórica é um fenômeno universal no Império, o que se ilustra pelas frequentes viagens dos sofistas a todas as suas partes" (MARTINS e BRENER, 2017, p. 23).

${ }^{23}$ Como exemplo, veja-se a atitude do procônsul Gálio (Atos 18:12-17) diante das queixas dos religiosos judeus contra Paulo parece refletir a indiferença do governo romano para com o cristianismo.
} 
"Zombarias de todo tipo foram adicionadas às suas mortes. Cobertos com peles de animais, eles foram rasgados por cães e morreram, ou foram pregados em cruzes, ou foram condenados às chamas e queimados, para servir como iluminação noturna, quando a luz do dia tinha expirado."

Nero abriu o precedente e outros imperadores seguiram seu exemplo, perseguindo os seguidores de Cristo com diferentes graus de intensidade. ${ }^{24}$ Ser um cristão durante esses períodos de intolerância era uma escolha que poderia custar a vida, e os relatos de martírio passaram a ser tema presente em diversos textos apologéticos, exortativos ou narrativos. ${ }^{25}$ Entre estes últimos encontram-se os Atos ( $\left.\pi \rho \alpha ́ \xi \varepsilon 1 \zeta / A c t a\right)$ que relatam as aventuras e provações experimentadas por alguns dos discípulos de Jesus em suas atividades missionárias, cujo ápice é a deposição da vida pela causa cristã através do martírio. ${ }^{26}$ Os principais textos desse grupo, que hoje é conhecido por Atos Apócrifos dos Apóstolos, são narrativas sobre André, João, Paulo, Pedro e Tomé. ${ }^{27}$

Sua autoria, como o termo apócrifo (adotado posteriormente) indica, é desconhecida. O único que tem uma indicação do autor é Atos de Paulo, o qual, segundo Tertuliano, foi escrito por um presbítero da Ásia, que, no entanto, permanece anônimo. Fócio, um patriarca de Constantinopla no século IX, após ler um volume que reunia as cinco obras, afirmou que o autor das mesmas seria Leucio Carino. ${ }^{28}$ No entanto, é consenso entre os estudiosos que tais textos não apenas possuem autores diferentes, mas se originam em círculos distintos, como observa Vielhauber (2005, p. 720, destaque nosso): “Apesar de se repetirem determinados temas e de alguns pontos teológicos

\footnotetext{
${ }^{24}$ Em sua História Eclesiástica, Eusébio cita Domiciano, Trajano, Adriano e outros. As datas das perseguições e os imperadores responsáveis por elas, desde o século I ao IV, são: Nero (64-68), Domiciano (81-96), Trajano (109-111), Marco Antônio (161-180), Sétimo Severo (202-210), Maximino (235), Décio (250-251), Valeriano (256-259)111, Diocleciano112 (303-312/3) e Juliano, o Apóstata (361-363). Cf. SÁNCHEZ, 2013, p. 42.

${ }^{25}$ Entre estes constam-se também as atas dos mártires, que relatam as cenas de julgamento e condenação de cristãos dos primeiros séculos. Bardenhewer (apud MUSURILLO, 1992 liii) as divide de acordo como o tipo de redação, em 1) registros dos tribunais, 2) narrativas e 3) lendas. Para Sánchez (2013, p. 63), as atas e os AAA formam os antecedentes diretos da hagiografia (a partir do sec. IV), diferenciando-se desta pela narração no martírio, enquanto a forma do século IV narra a vida exemplar do santo, uma consequência da ascenção da igreja ao domínio político e a extinsão das perseguições.

${ }^{26}$ Para uma discussão sobre o gênero desses textos cf. SÁNCHEZ, 2013, p. 31.

${ }^{27}$ Cf. PERVO, 2014, p. 41; SÁNCHEZ, 2013, p. 33; BARRIER, 2008, p. 15; JOHNSON (2017,p.9) .

${ }^{28}$ Barrier, citando Fócio, afirma que Lêucio Carino foi um maniqueísta egípcio do século IV (Cf. 2008, p. 15). Já Sánchez afirma que a origem da compilação dos cinco AAA no século IV é maniqueista, mas que o nome de Lêucio estivera vinculado aos Atos de João (século II) e que posteriormente os outros Atos teriam sido atribuídos a ele pelos seguidores de Maniqueu. Cf. SÁNCHEZ, 2013, p. 71.
} 
comuns, os Atos Apócrifos dos Apóstolos não formam uma unidade; cada um desses livros tem sua própria marca teológica e literária, e deve ser avaliado em separado". ${ }^{29}$ O texto de Atos de Paulo, cujo núcleo principal é formado por Atos de Paulo e Tecla, a Terceira epístola aos coríntios e O martírio de Paulo, ${ }^{30}$ geralmente é considerado o mais antigo deles ${ }^{31}$, mas os pesquisadores divergem bastante quanto à datação. ${ }^{32}$ Como Tertuliano escreveu De Baptismo por volta do ano 200 d.C, a composição de $A P$ não pode ser posterior ao fim do segundo século e início do terceiro. Esse é, portanto, seu terminus ante quem. No entanto, encontrar o terminus post quem se mostra bem mais problemático. É significativo notar que, à época de Tertuliano, $A P$, provavelmente composto na Ásia Menor, já havia alcançado Cartago e provocado debates. ${ }^{33}$ Ou seja, sua composição se deu com antecedência suficiente para chegar até a essa região do Império antes do ano 200 d. C.

Há ainda outros elementos de datação. Bremmer (2001, p. 153) chama a atenção para o nome de Falconila, a filha da rainha Trifena, personagem em APT, como um possível indicador de que a composição fora posterior a 160 d.C, já que a presença desse nome raro pode estar relacionada a Pompeia Sosia Falconilla, esposa de um cônsul romano de 169 d.C.. ${ }^{34}$ Já Ramsay conclui que o autor pertenceu à igreja no período em que o montanismo se desenvolvia, mas antes que as disputas com seus adeptos começassem (após 150 d.C.). Por outro lado, Hilhorst chama a atenção para um trecho de De uiris illustribus (escrito nos últimos anos do século IV), no qual Jerônimo, comentando o autor cartaginês, afirma que o tal presbítero mencionado por Tertuliano

\footnotetext{
${ }^{29}$ Cf. SÁNCHEZ, 2013, p. 71 e 79; BARRIER, 2008, p. 15.

${ }^{30}$ Cf. SÁNCHEZ, 2013, p. 35. Como o texto não é estável, sua composição depende da conjectura dos editores e de suas diversas fontes. Rodorf, na introdução ao texto que está nos Écrits apocryphes chrétiens, vol. I. (Paris: Gallimard: 1997, p. 1119) diz o seguinte: “Aparentemente os Atos de Paulo narraram toda a vida missionária do apóstolo, desde a sua conversão, nas cercanias de Damasco até seu martírio em Roma. As diverentes etapas são as seguintes: I. Damasco; II. Antioquia, na Síria; III. Iconio; IV. Antioquia da Psídia; V. Mira; VI. Sidon; VII. Tiro; VIII. Jerusalem; IX. Éfeso e Macedônia; X. Philippi; XI. Corinto; XIII. Viagem pela Itália; XIV. Roma". A sequência narrativa seria então: 1. Conversão no caminho de Damasco (texto muito corrompido), 2. Início da missão apostólica na Antioquia (idem); 3-4. corresponde aos APT; 5-10. missão apostólica; 11. Aos Coríntios; 12-13. missão apostólica; 14. Martírio na Roma neroniana".

${ }^{31}$ Cf. SÁNCHEZ, op. cit., p. 34; PERVO, 2014, p. 41.

${ }^{32}$ Para as controvérsias sobre a datação, cf. SÁNCHEZ, 2013, p. 69 e 70 e BARRIER, 2008, p. 46 a 48.

${ }^{33}$ Sobre a origem na Ásia Menor, afirma-o o próprio Tertuliano. Para mais elementos que apontam isso, cf. BREMMER, 2001, p. 153.

${ }^{34}$ Neste ponto Bremmer concorda com Ramsay (1893, p. 407), para quem o nome Falconila indica uma adição do segundo século, já que ele não teria ocorrência no gens Antonia e teria se tornado popular na Ásia quando Falco se tornou procônsul em 130 d.C. Se Bremmer estiver correto, a compilação de $A P$ se deu durante o auge de popularidade dos romances antigos, como pontua Barrier (2008, p. 47).
} 
fora condenado por João, o apóstolo. ${ }^{35}$ Se essa informação é verdadeira, ${ }^{36}$ a data de elaboração da obra precisa recuar para algum período entre a morte de Paulo (68 d.C.) e a de João (98 d.C.). ${ }^{37}$ Porém, outros pesquisadores parecem não ter tanta segurança na afirmação de Jerônimo. Pervo (2014) e Sánchez (2013) silenciam sobre a intervenção de João; Ramsay (1893, p. 414) considera discutível a autoridade do argumento de Jerônimo já que ele cita Tertuliano e este, por sua vez, nada fala sobre João; e Barrier não a toma como certa, mas conjectura que AP tenha levado cerca de 100 anos para tomar a forma criticada por Tertuliano ${ }^{38}$ e apoia sua opinião em indícios de que as partes que o formam foram escritas em épocas diferentes e que sua composição final ${ }^{39}$ teria se dado entre 160 e 170 d.C. ${ }^{40}$ Evidentemente, os debates quanto à datação de Atos de Paulo, dificilmente chegarão a um consenso. Mas, ainda que uma datação mais precisa não se mostre possível até o momento, podemos situar o processo de formação da obra, com base na discussão acima, entre meados do século I e do II d. C., o que evidencia a antiguidade do texto que é objeto deste estudo: Atos de Paulo e Tecla.

Para facilitar a leitura dos capítulos seguintes aos não familiarizados com a obra, segue um resumo dos $A P T$, cujo conteúdo está distribuído em dois capítulos, correspondentes aos 3 e 4 dos Atos de Paulo, que perfazem 43 seções ao todo. Em 3.1-25 a ação se passa em Icônio e em 4.26-43, na Antioquia da Psídia.

Os APT têm início com a chegada de Paulo a Icônio, fugindo de perseguições em Antioquia, acompanhado de Demas e Hermógenes, dois falsos crentes. Ele é recebido por Onesíforo, cuja casa se torna o centro da pregação de Paulo. Na casa vizinha, sentada à janela, uma jovem de nome Tecla escuta os discursos de Paulo a respeito da castidade. Ela está tão envolvida com as palavras do apóstolo que não se move da janela dia e noite,

\footnotetext{
${ }^{35}$ Cf. HILHORST, 1996, p.158 e 159.

${ }^{36}$ Questiona-se, porém, que Tertuliano não precisaria se dar ao trabalho de revelar fatos sobre o autor do texto se estes já fossem conhecidos há tanto tempo. Por outro lado, Jerônimo diz que Tertuliano uicinus illomm temporum (viveu próximo daqueles tempos - tradução minha, a partir do inglês), o que dá a entender que há um erro de cronologia da parte de Jerônimo. Cf. HILHORST, 1996, p. 160 e 161.

${ }^{37}$ Hilhorst (1996, p. 159-162) comenta que, na interpretação de Jerônimo, Paulo teria desmentido os fatos, se estivesse vivo à época em que a obra fora escrita, portanto, ela teria que ser uma produção posterior à morte dele (Ibid., p. 160).

${ }^{38}$ BARRIER, 2008, p. 48. Apesar de supor esse longo período de elaboração da história de Tecla, ao elencar as várias propostas de datação de estudiosos, Barrier (loc. cit. p. 46) cita a posição de Gutschmidt para quem o terminus a quo da obra seria por volta de 38-63 d.C., quando viveu uma rainha Trifena na região do Ponto. Para detalhes quanto a essa descoberta arqueológica, cf. RAMSAY, 1893, p. 382 et seq.

${ }^{39}$ Davis (2001, p. 14) chama a atenção para o vocabulário de Tertuliano (construxit, compor, e cumulans, acumular), que indica uma compilação e não uma autoria dos textos. Cf. nota 7.

${ }^{40}$ BARRIER, loc. cit. e também p. 44. Cf. NOGUEIRA, 2016, p. 24, e SÁNCHEZ, 2013, p. 35. Mais tarde, $A P T$ voltou a aparecer em textos independentes de AP. Cf. BARRIER, 2008, p. 51 e SÁNCHEZ, 2013, p. 67.
} 
nem dá atenção a quem quer que se dirija a ela. Sua mãe interpreta isso como uma paixão e, alarmada, manda chamar Tamiris, a quem Tecla está prometida. Perturbado com a novidade, ele intercepta Demas e Hermógenes, traidores do apóstolo, em busca de informações. Seguindo seus conselhos e com a ajuda de uma multidão, o enciumado noivo leva Paulo diante do governador, que manda encarcerar o apóstolo. Tecla suborna os guardas e consegue acesso à cela, onde senta-se a seus pés para ouvir mais ensinamentos. Descobertos, os dois são levados ao tribunal. O apóstolo é expulso da cidade e Tecla é condenada à fogueira em razão de recusar a se casar com Tamiris a fim de guardar sua castidade. No entanto, por intervenção divina, uma chuva torrencial cai sobre o teatro apagando as chamas e provocando destruição, o que leva à libertação da jovem.

Tecla, com a ajuda de um dos filhos de Onesíforo, consegue reencontrar Paulo, que havia se recolhido em jejum e oração, e ambos se dirigem a Antioquia. Ali ela é assediada por Alexandre, um membro da elite da cidade (um sacerdote imperial, na opinião de Bremmer ${ }^{41}$ ). Enquanto Paulo desaparece de cena, a jovem resiste e, na luta para desvencilhar-se, rasga o manto de Alexandre e arranca sua coroa. Ofendido, ele a denuncia ao governador e o instiga a condená-la a lutar com feras, em um espetáculo público. Tecla solicita ao governador que ela tenha sua castidade preservada e, então, é colocada sob a custódia de Trifena, uma rainha que havia perdido sua filha, Falconila. Durante o convívio com Tecla, Trifena é atraída para a fé cristã e se apega a sua hóspede. No momento do suplício, a intervenção divina se manifesta através de uma leoa, que protege a jovem das demais feras que a atacam. A heroína lança-se, então, a um tanque de água, no qual decide batizar-se. No entanto, o local esconde perigosos animais marinhos, o que leva o auditório feminino à comoção. Atingidos por um raio de luz, os animais boiam mortos e Tecla finalmente consegue seu batismo. Trifena passa mal e os jogos são suspensos, já que seu parentesco com o imperador desperta os temores de Alexandre, que roga ao governador a libertação de Tecla. Livre, a jovem descobre que Paulo está em Mira e se dirige até lá, onde recebe dele a autorização para pregar. Por fim, ela se dirige a Icônio, prega para sua mãe e, depois, segue para a Selêucia, onde dissemina sua fé até morrer em idade avançada.

Essa é a narrativa inserida em $A P$ que despertou os brios de Tertuliano e cuja origem, historicidade, autoria e recepção se mostram tão nebulosas quanto sua datação.

\footnotetext{
${ }^{41}$ Cf. Bremmer, 1996, p. 50 e 51. Ver também nota 34 da tradução.
} 
Sánchez, como vários outros pesquisadores, sugere que uma lenda sobre Tecla foi transmitida oralmente sofrendo ampliações e ajustes até atingir a redação que conhecemos, ${ }^{42}$ e Ramsay chega a propor uma reconstrução da formação da lenda. ${ }^{43}$ Quanto à historicidade do relato, Rordorf (1986) elenca pesquisadores que se alinham em três posições. Em um extremo estão o que defendem um núcleo histórico em $A P T$ o qual pode ser separado do conteúdo lendário indicando, assim, a autenticidade da maior parte da narrativa. Theodor Zhan e William M. Ramsay estão posicionados aí. No lado oposto, estão Schlau e Lipsius para quem, nas palavras de Rordorf, "a existência de uma Tecla que batizou a si mesma não é impossível, mas não pode ser provada" (1986, p. 46). ${ }^{44}$ Tentando equilibrar-se entre os dois grupos está Harnack e outros que procuram sintetizar os argumentos de ambas as correntes, concordando com a data proposta por Ramsay de 130 a 150 d.C. como período provável para a composição do texto escrito, mas afirmando que é impossível separar o material lendário do histórico e provar a autenticidade do relato.

Avançando para os terrenos da autoria e recepção, percebemos que os debates não pertencem apenas aos campos da origem e historicidade. Ao contrário, penetramos um vasto labirinto de suposições e encontrar uma saída parece tão sobrenatural quanto a luz que matou as focas assassinas no improvisado tanque batismal de Tecla. Se o desventurado presbítero citado por Tertuliano realmente organizou textos já conhecidos em uma única peça ou se o redigiu a partir de diversas tradições orais, não sabemos. ${ }^{45}$ Sánchez (2013, p. 74) acredita que a lenda inicial de Tecla fosse bem simples, sofrendo "ampliações e deformações para adornar a história e torná-la mais espetacular". No entanto, quantas revisões foram feitas no texto, e por quem, não é possível afirmar. ${ }^{46}$ Em

\footnotetext{
${ }^{42}$ Cf. SÁNCHEZ, 2013, p. 68 e 74, onde o autor cita que Magnona e Burrus afirmam a origem lendária da narrativa. Pervo (2014, p. 69) também adota esta posição.

${ }^{43}$ RAMSAY, 1892, p. 375 et seq. O autor elimina todos os elementos que julga infundados para o momento histórico da narrativa (entre 50 e 64 d.C), tentando encontrar o conto em sua forma mais simples. Para ele, pelo menos parte da narrativa é histórica, com Tecla sendo uma pessoa real que, por volta de 50 d.C. entrou em contato com grandes figuras da província da Galácia como Paulo, a rainha Trifena e o governador romano (cf. p. 388).

${ }^{44}$ Jonhson (2017, p. 676) admira-se do sucesso da história de Tecla já que não há evidência alguma de sua historicidade. Ainda mais longe vai Arnold Rey, para quem Tecla nunca existiu. Cf. Rordorf, 1986, p. 46. ${ }^{45}$ Por "tradições orais", refiro-me tanto a trechos da lenda de Tecla, quanto das epístolas pastorais e outros textos que mais tarde formaram o cânon do Novo Testamento.

${ }^{46}$ Ramsay deduz que uma revisão foi feita após 130 d.C. por alguém que provavelmente viveu na província da Ásia (Tiatira ou Troas), mas nunca esteve em Antioquia ou Icônio. Para ele, embora esse revisor não faça referência às questões levantadas pelas querelas com os montanistas, seu tom "é o das condições em que o Montanismo cresceu" (1893, p. 416). Pervo também reconhece a ligação como essa dissidência do cristianismo quando diz que "o escritor pode ser simpático à Nova Profecia ('Montanismo), mas não discute essa controvérsia ou outras [...] (2014, p. 70).
} 
largo contraste com a afirmação do apologista cartaginês, há quem deduza uma autoria feminina para $A P T$, enquanto outros rejeitam completamente a hipótese. ${ }^{47}$

Outra discussão indefinida é quanto ao público alvo. Segundo Dunn (2006), para Davies, o destaque de Tecla e de outras personagens femininas na narrativa indica que o texto teria sido elaborado por e para mulheres porque apresenta, segundo o pesquisador, um olhar antagônico quanto aos homens. ${ }^{48}$ Dunn (2006, p. 59) considera essa posição exagerada, de comprovação exígua. Para o estudioso americano, "a evidência não sugere um público leitor exclusivamente de mulheres, mas de homens ricos, das classes superiores também" (DUNN, 2006, p. 41). E Barrier entende que a crítica de Tertuliano é também uma indicação de que havia leitores homens. Por outro lado, Pervo (2014, p. 42), comentando a mesma passagem de Tertuliano, nota "que pelo menos algumas mulheres liam o texto e o viam como um modelo". Sánchez, reconhece que "uma narrativa como a de Tecla gozaria de grande fama entre as mulheres cristãs", mas entende que os Atos Apócrifos (os quais incluem APT) não seriam “destinados exclusivamente a um público feminino, senão a diferentes comunidades cristãs [...]” (2013, p. 82).

Com poucos testemunhos remanescentes de contemporâneos ao texto, o trabalho de pesquisa nesses campos torna-se bastante penoso e o caminho das suposições muitas vezes é tomado, o que causa as frequentes contestações entre os pesquisadores. Porém, apesar de tantos tópicos pontuados por dúvidas, uma coisa é certa: embora o presbítero mencionado por Tertuliano tenha perdido seu posto, indicando a desaprovação de seu trabalho, o texto não perdeu a popularidade. Sánchez (2013, p. 67) chama a atenção para a grande difusão desta obra que se originou na Ásia em meados do século II (ao menos na forma que conhecemos), foi mencionada por um escritor de Cartago (no final do mesmo século) e apareceu pouco tempo depois (202-204) no Comentário sobre Daniel,

\footnotetext{
${ }^{47}$ A favor da hipótese da autoria feminina, Sánchez (2013, p.76) cita Davies e Kaestli. Para uma posição contrária, cf. BREMMER, 1996, p. 58 e DUNN, 2006, p. 59.

${ }^{48}$ Dunn cita MacDonald, Burrus e Rodorf entre outros autores que defendem a mesma posição de Davies (2006, p. 56). Dunn rejeita a hipótese defendida por MacDonald de que $A P$, seja uma resposta às cartas pastorais (que apontam algumas restrições às mulheres) preparada por uma espécie de movimento feminista da antiguidade cristã, que usa o ascetimo (especialmente a renúncia ao sexo), para libertar-se da opressão masculina, tanto na igreja, quanto na sociedade (op. cit, p. 48). Para ele, "o conflito entre $A P$ e as CP existe apenas em um nível superficial" e que, na verdade há "uma profunda conformidade entre as duas tradições" (idem, p. 100). Embora as conclusões de Dunn se oponham ao trabalho de pesquisadores como MacDonald, Burrus e Rodorf, que defendem a mesma posição de Davies, seus argumentos são bastante plausíveis e ampliam consideravelmente os rumos da pesquisa. Para conferir a análise e conclusão de Dunn acerca dessa conformidade entre $A P$ e as CP, cf. DUNN, 2006, p. 47 et seq.
} 
de Hipólito, em Roma. ${ }^{49}$ Um desempenho e tanto para uma época em que a multiplicação dos livros era um trabalho árduo e muito custoso, e para um texto cujo autor teve seu trabalho questionado.

A julgar pela declaração exasperada do apologista cartaginês, a obra não era vista com bons olhos pela vertente ortodoxa do cristianismo. Mas será que essa impressão é verdadeira? Há quem não entenda assim. Vielhauer (2005, p. 731) declara que "os Atos de Paulo ${ }^{50}[\ldots]$ não foram considerados heréticos pela Igreja oficial”. Essa também é a opinião de Dunn e de Sánchez. ${ }^{51}$ O estudioso espanhol afirma que, pelo contrário, APT era bem conhecido no meio eclesiástico e até visto positivamente (SÁNCHEZ, 2013, p. 68). Mesmo o encargo incomum de Tecla, transgressor na visão de Tertuliano, parece não ter impedido que a obra fosse lida e apreciada. A esse respeito, Zamfir (2016, p. 358) entende que:

\begin{abstract}
"pelo menos em algumas (provavelmente ascéticas) comunidades, mulheres ensinavam inspiradas e legitimadas pela história de Tecla. Parece provável que isso tenha sido percebido como uma prática aceitável, não como quebra de mandamentos divinos ou apostólicos".
\end{abstract}

Como era de se esperar, da mesma forma que os outros tópicos, esse também apresenta opiniões variadas. Barrier (2008, p. 70), baseado em Tertuliano, afirma que inicialmente $A P T$ era considerado um texto herético ${ }^{52}$ por causa da presença do elemento erótico e de temas seculares encontrados nos romances e nos espetáculos romanos. Linha semelhante é adotada por Hilhorst (1996, p. 163), para quem AP desde o início foi "apócrifo" 53 e que "nunca teve qualquer status oficial no meio em que foi escrito". A grande proximidade com o romance grego (como veremos mais adiante), a falta de

\footnotetext{
${ }^{49}$ Scheneemelcher (2003, p. 222) observa que "a ampla disseminação de APT mostra que essa parte dos antigos Atos, separada de $A P$, certamente foi influente".

${ }^{50}$ Apesar de se referir a Atos de Paulo, APT evidentemente está incluído nessa afirmação.

${ }^{51}$ Para Dunn (2006, p. 64), uma análise mais atenta revela que Tecla não contrariou os ensinos de Paulo nas EP pois ela prega apenas para mulheres e não há registros de que tenha batizado alguém mais além dela mesma, não tendo, portanto, causado qualquer escândalo: "A reação de Tertuliano é uma exceção, pois ninguém mais reage tão negativamente em relação a Tecla". Uma explicação para a indignação de Tertuliano é que a versão dele talvez contivesse algum trecho mais controverso, que tenha sido retirado do texto posteriormente. Cf. RAMSAY, 1893, p. 376.

${ }^{52}$ Vielhauber (2005, p. 721) entende que a origem dos AAA "de modo algum é 'herética', antes se encontra nos elementos pagãos preliminares do cristianismo vulgar. Mas esses elementos atraíram outros da mesma espécie e formaram solo fértil para pensamentos 'heréticos' ". No entanto, isso não contradiz totalmente Barrier, que se refere ao texto (talvez como o que Tertuliano tinha em mãos) como sendo considerado herético e não sua origem. Mesmo assim, aqui se levanta uma questão: Considerado herético por quem? Quantos além de Tertuliano rejeitavam APT?

${ }^{53}$ Aqui entendido como não autorizado, considerado falso.
} 
precisão histórica e geográfica, os elementos lendários presentes na narrativa, além da presença do elemento erótico (como Barrier aponta) talvez sejam alguns dos fatores pelos quais a vertente ortodoxa do cristianismo não tenha dado um caráter "oficial" a $A P$ e aos outros AAA. E é indício notável disso que tais textos não foram adicionados ao cânon dos livros considerados sagrados. No entanto, apesar da ausência de reconhecimento institucional, a grande difusão da obra atesta que "a Igreja não quis ou não pôde neutralizar essa literatura tão estimada" (VIELHAUER, 2005, p. 722). Pervo (2014, p. 41) reforça essa posição ao afirmar que $A P$ ( $A P T$ incluso) foi o AAA mais aceito dentro dos círculos católicos sendo condenado posteriormente "mais por seu uso pelos heréticos, notavelmente os Maniqueístas e os seguidores de Prisciliano, que por suas doutrinas". ${ }^{54}$ Entretanto, mesmo essa condenação de $A P$ parece não ter prejudicado tanto o prestígio da história de Tecla, já que sua protagonista, na tradição católica, é considerada a primeira mártir do cristianismo ${ }^{55}$ e se tornou uma santa muito popular, com templos e festas dedicados a ela, além de ser eleita como padroeira de várias cidades ${ }^{56}$ Em realidade, o enredo de $A P T$ sobreviveu à oposição de Tertuliano (e, quiçá, de outros) e à condenação dos AAA, desvinculando-se de $A P$ para ter uma carreira solo e, posteriormente, dar origem à Vida e milagres de Santa Tecla, uma extensa obra anônima do século V que foca sobretudo na narração de milagres atribuídos à corajosa discípula de Paulo. ${ }^{57}$

Mas, qual a razão para o sucesso de $A P T$ ? Como esse texto aparentemente simples, contendo passagens polêmicas e discutíveis, conseguiu se tornar popular e atrair leitores até em partes remotas do Império, por um longo período de tempo? A análise literária da obra permite que encontremos os recursos utilizados pelo autor para não apenas transmitir seu recado, mas para tornar o leitor simpático à sua mensagem. É o que nos propomos a fazer na sequência.

\footnotetext{
${ }^{54}$ Pervo (2014, p.42) também afirma a aceitação de $A P$ como histórico desde o início do terceiro século até tempos depois do final da Idade Média.

${ }^{55}$ Cf. SÁNCHEZ, 2013, p. 6. Além de concordar com Sánchez, Jonhson (2017, p. 676), chega a dizer que Tecla foi mais popular que a virgem Maria até o quinto século. Por outro lado, Pervo (2014, p. 42) afirma que "o nome de Tecla foi removido do Roman Catholic Sanctrale (calendário da Igreja) em 1969, por causa de dúvidas sobre sua existência histórica. Ela permanece em vários calendários orientais".

${ }^{56}$ No Brasil, é padroeira de Capão do Leão, RS. No mesmo Estado, a santa dá nome a bairros e ruas de algumas cidades e a um forte. Em Tarragona, na Catalunha, as festas em homenagem a Tecla são célebres, com duração de 10 dias, mesclando atos religiosos com desfiles, músicas e apresentações artísticas, culminando com uma concorrida procissão onde um osso de braço, atribuído à Santa, é transportado pela cidade. Cf. < https://www.tarragona.cat/cultura/festes-i-cultura-popular/santa-tecla $>$. É considerada também a protetora dos agonizantes. Cf. em < http://santossanctorum.blogspot.com/2011/10/santa-teclapadroeira-dos-agonizantes.html > consultado em 03/01/2019.

${ }^{57}$ Sobre essa última, cf. Johnson, S. F. The life and miracles of Tekla: a literary study. Cambridge: Center of Hellenic Studies, 2006.
} 


\title{
CAPÍTULO 2 \\ Uma análise literária
}

\author{
"Vá e pregue a Palavra de Deus" \\ (Atos de Paulo e Tecla, seção 41). \\ "Aqueles que não veem o que acontece, \\ pensam que veem o que não acontece." \\ TERTULIANO, Apologia. IX.
}

O que se esperaria de um noivo ou marido cuja noiva/esposa resolvesse seguir certo pregador itinerante que a convencera de não se casar (no caso da noiva) ou de se afastar do leito conjugal (no caso da esposa) a fim preservar a castidade? A não ser que tal noivo/marido já fosse um adepto do dito pregador, é óbvio que a reação natural estaria muito distante da aceitação. Nos AAA, “uma, se não $a$, posição missionária é uma aversão ao intercurso sexual, mesmo dentro do casamento legal" (PERVO, 1996, p. 693 - itálico do autor). Por isso, uma cena recorrente nessas obras é a de maridos e noivos enfurecidos e no encalço dos apóstolos que transmitem o impopular ensino.

Em APT não é diferente. Paulo faz sua pregação acerca da castidade para mulheres e jovens que vêm para ouvi-lo na casa de Onesíforo, em Icônio. Enquanto isso, Tecla, virgem e prometida em casamento, o escuta na casa ao lado e deseja estar entre os bemaventurados castos descritos nos discursos do apóstolo, o que implica em abandonar os planos de matrimônio. A renúncia da moça às núpcias deixa seu noivo, Tamiris, atordoado. Este, quando percebe que o casamento está em risco, inicia um levante contra o apóstolo, o que, por fim, acarreta o martírio de Tecla.

A preservação da castidade e o martírio (temas que serão novamente abordados no capítulo três desta dissertação) formam o núcleo do enredo nos dois episódios de $A P T$, o primeiro em Icônio e o segundo em Antioquia. ${ }^{58}$ Ambas as narrativas seguem a mesma estrutura: Tecla rejeita um proeminente homem da cidade, o que a leva a julgamento e condenação, da qual ela escapa por intervenção divina. Sánchez (2013, p. 87) chama a

\footnotetext{
${ }^{58}$ Pervo (2014, p. 88) acredita que os acontecimentos em Icônio tenham sido uma duplicação dos eventos em Antioquia. Já Sánchez (2013, p. 86) apresenta duas hipóteses: a fusão de duas lendas distintas e a mera casualidade, vinda do desenvolvimento normal dos fatos e da necessidade de dar destaque a Tecla. Note-se que a duplicação de episódios, como uma forma de fazer evoluir a narrativa, é um recurso comum aos autores do período, particularmente notável nos contemporâneos As efesíacas, de Xenofonte de Éfeso, e Romance de Esopo, de autoria anônima, podendo, inclusive ser visto como um resquício de composição oral.
} 
atenção também para organização circular do enredo: em Icônio, Tecla e Paulo se encontram pela primeira vez, se separam e se reencontram depois do frustrado martírio da moça. Em Antioquia, o início da narrativa começa com os dois juntos, há a separação e o posterior reencontro em Mira. Nas duas partes o momento de maior tensão acontece durante os martírios enfrentados pela jovem.

Na primeira parte (da seção 1 à 25), o ritmo da narrativa começa lento, cadenciado pelas apresentações dos personagens e os discursos de Paulo. A sequência de ações aumenta aos poucos, com as acusações de Tamiris, a prisão de Paulo, a visita de Tecla à cadeia, o julgamento e condenação de ambos, e atinge seu auge na seção 22 , que descreve todo o processo da execução da sentença da moça e, em menos de quatro linhas, apresenta as impressionantes manifestações divinas que a livram da morte:

\footnotetext{
Então, Deus, tendo se compadecido, provocou um estrondo subterrâneo e cobriu de sombra o alto com uma nuvem cheia de água e granizo, e todo o seu conteúdo foi derramado de tal maneira que muitos ficaram em perigo e morreram, o fogo foi apagado e Tecla foi salva.
}

As próximas seções (23 a 25) voltam a um ritmo mais tranquilo, preparando o caminho para a aceleração irregular que se seguirá. Na seção 26, que marca o início da segunda parte, as ações se sucedem rapidamente: Paulo envia Onesíforo e família de volta a Icônio, vai com Tecla para Antioquia, onde ambos são abordados por Alexandre (um possível sacerdote imperial), o apóstolo desaparece e a jovem discípula enfrenta energicamente o assediador, rasgando-lhe o manto e derrubando-lhe a coroa. De 27 a 32, a seguidora de Paulo é mais uma vez levada à julgamento e condenada (desta vez para ser lançada às feras). Seguem-se as cenas um pouco mais lentas na casa da rainha Trifena, nobre a quem é dada a custódia da moça, entremeadas de discursos e lamentações. A partir daí, o ritmo narrativo cresce novamente enquanto a batalha com as feras na arena se aproxima. Da 33 à 36, que relatam os acontecimentos do martírio, a sucessão de fatos é acelerada ao máximo: uma leoa defende Tecla dos ataques de outras feras; a moça decide batizar-se em um tanque cheio de ameaçadoras focas e é salva por pouco através de um facho mortal de luz que atinge as criaturas marinhas e, ao mesmo tempo, oculta a nudez da jovem; outros animais ferozes são lançados contra ela, mas são neutralizados por odores soporíferos de plantas jogadas na arena pelas mulheres da plateia. Por fim, Tecla é amarrada a dois touros torturados por ferro incandescente nos genitais, mas uma chama queima as cordas e ela escapa de ser pisoteada. Nesse momento, a rainha Trifena 
desmaia e é dada como morta; Alexandre, apavorado com a possibilidade de que o imperador, parente da rainha, se vingue da cidade, pede ao governador que solte a condenada. Tudo é narrado em alta intensidade até a seção 37, na qual Tecla expressa publicamente sua fé em Deus perante o governador, e o leitor finalmente começa a se recuperar da eletrizante sequência das seções anteriores.

As próximas duas seções, 38 e 39, celebram a vitória e libertação de Tecla e, a partir daí a narrativa se dirige para a conclusão em ritmo desacelerado, já que os acontecimentos também se encaminham para a normalidade, sem grandes conflitos para serem resolvidos. É o momento de atar os nós, com a promoção de reencontros com figuras que marcaram a trajetória da heroína: Trifena, Paulo e sua mãe. Tecla é recebida na casa de Trifena, onde converte as servas da rainha e recebe uma gratificação vultuosa de sua protetora. Com saudades de Paulo, a jovem o localiza e vai ao seu encontro seguida por um séquito de servas (e/ou servos, pois o texto é ambíguo aqui). Ela lhe entrega as doações de Trifena, recebe a autorização dele para pregar, dirige-se a Icônio, prega para Teóclia, sua mãe, e, por fim, vai para a Selêucia, onde "tendo iluminado a muitos com a Palavra de Deus, dormiu um belo sono" (seção 43).

Mas toda a movimentação da narrativa é feita por personagens. Quem são eles? Quais as suas motivações? As ações são positivas ou não? Um narrador em terceira pessoa e externo à narrativa apresenta as respostas para essas e outras questões. Ele nos conta, por exemplo, que os companheiros de jornada de Paulo no início da trama, Demas e Hermógenes, são "cheios de falsidade" e que Paulo não lhes fazia mal porque tinha "em vista apenas a bondade de Cristo". Algumas vezes o narrador expressa claramente sua opinião (a morte de Tecla, por exemplo, é descrita como um belo sono), mas em grande parte da narrativa, ele apenas relata os acontecimentos, organizando-os, contudo, de modo a criar certas impressões no leitor. A fuga de Tecla, uma atitude de escandalosa rebeldia para uma jovem de boa família, é apresentada como um ato de coragem e amor já que ela o praticou para ouvir "as grandezas de Deus", resultando no crescimento de sua fé. Não há dúvida que ele assume o ponto de vista dos personagens cristãos e, não o dos gregos não convertidos. Um exemplo é a forma como Tamiris é representado. Para conseguir informações a respeito de Paulo, ele oferece dinheiro a Demas e Hermógenes, além de os adular com um suntuoso banquete. Ao invés de propor um enfrentamento entre ele e seu suposto rival, Tamiris vai em busca de Paulo acompanhado de autoridades, funcionários e do povo da cidade, armados com paus. Essas atitudes manipuladoras e covardes são elaboradas de forma a anular, como diz Pervo (2014, p. 11), qualquer traço de simpatia 
com o decepcionado noivo. ${ }^{59}$ No entanto, aqueles que são abertos a ouvir a mensagem cristã (os dois governadores) ou a defender Tecla (as mulheres de Antioquia, incluso Trifena) são apresentados de forma a despertar uma opinião favorável no leitor.

A narrativa traz os tempos verbais predominantemente no passado, marca associada ao registro historiográfico, e sequencia os acontecimentos. Portanto, eles são conhecidos pelo narrador, que os apresenta em ordem temporal, sem flashbacks ou antecipações. Mas o intervalo de tempo entre o narrador e os eventos narrados não é extenso. Os costumes e ambientações não são estranhos a ele, nem ao público a quem se direciona, dado que ele não se preocupa em explicá-los. Embora não haja uma elaboração sofisticada desse narrador, ele consegue criar expectativas, despertar emoções e apresentar as informações necessárias para conduzir o leitor a uma visão positiva de Paulo e, principalmente, de Tecla.

As descrições são muito econômicas. Como são Icônio e Antioquia? Grandes ou pequenas? Agitadas ou pacatas? Ao que parece, o narrador não vê necessidade de dar maiores detalhes. À parte a discussão sobre a qual Antioquia ${ }^{60}$ o texto se refere, ambas são bastante conhecidas do público da antiguidade, portanto uma apresentação minuciosa delas não é necessária. Antioquia da Psídia se encontrava na região montanhosa da Psídia, na fronteira com a Frígia. Icônio, por sua vez, localizava-se na Anatólia Central, ambas onde hoje está situada a Turquia. Antioquia da Síria ficava na região costeira do leste do mediterrâneo, na atual Síria, e abrigava uma importante comunidade cristã nos dias de Paulo. ${ }^{61}$

Em Icônio, as ações têm por cenário a casa de Onesíforo, a de Tecla e a de Tamiris e, nos espaços públicos, as ruas, o tribunal, a prisão, o teatro, o mercado e até uma tumba vazia. ${ }^{62}$ Os acontecimentos em Antioquia se passam na rua, no tribunal, na casa de Trifena e no estádio. Mas esses lugares, em ambas as cidades, são apenas mencionados, sem que se lhes acrescente maiores detalhes; tampouco é descrita a Selêucia, onde a narrativa se finda. Somente o que está relacionado aos fatos recebe alguma atenção. Da casa de Tecla sabe-se que havia uma janela voltada para a casa do vizinho e uma porta, da qual Tamiris saltou direto para a rua. Na residência deste, o leitor pode ver uma mesa suntuosa e farta, o que faz pressupor abundância de recursos. Nada é dito da casa de Trifena, além de que

\footnotetext{
${ }^{59}$ Por outro lado, essa estratégia também serve para evitar a antipatia por Paulo, que é, em última instância, o causador do infortúnio de Tamiris.

${ }^{60}$ Cf. apêndice 1, seção 1. Anabaínontos.

${ }^{61}$ Para compreender a posição geográfica dessas localicades, cf. apêndice 2.

${ }^{62}$ Embora tal tumba também possa estar próxima a Antioquia da Síria. Cf. GOODSPEED (1901, p. 187).
} 
abriga muitas servas e riquezas, parte das quais são entregues posteriormente a Tecla. Obviamente a posição social dos personagens é indicativa do tamanho e requinte de suas moradias, mas o leitor fica livre para exercitar a imaginação quanto à aparência delas.

A mesma ausência de detalhes se dá com os personagens. As exceções são Paulo, Tecla e Alexandre, descritos com alguma atenção. Do último sabemos que se vestia com elegância e pompa, já que ostentava uma coroa e uma clâmide. ${ }^{63}$ De Tecla somos informados de que era bela. Paulo é o único que recebe uma descrição mais minuciosa, praticamente um retrato falado: ele era "de pequena estatura, calvo, de pernas curvas, sadio, monocelha, nariz um pouquinho comprido, cheio de graça: ora aparentava ser homem, ora tinha a face de um anjo." (seção 3).

Levando em conta as características expostas, se o autor de $A P T$ escreveu a obra por amor a Paulo, como cita Tertuliano, por que apresenta o personagem com traços tão pouco atraentes ${ }^{64}$ Que função tal aparência exerce na narrativa? Como pode colaborar para a construção de uma imagem positiva do apóstolo? Vários estudiosos têm se debruçado na busca de respostas para questões como essas e o que encontraram, mais uma vez, não foi o consenso. ${ }^{65}$ Bollók, Barrier, Sánchez e Pervo, apresentam as visões divergentes de vários pesquisadores que procuraram auxílio em documentos da antiguidade. ${ }^{66}$ Descrições semelhantes às de Paulo foram encontradas em listas de escravos foragidos no Egito e nos registros de uma terra vendida. Bollók (1996, p. 4 e 5) observa que tais listas têm em comum com $A P T$ o uso da descrição como um meio de identificar um indivíduo. Mas chama a atenção para o fato de as características interiores de Paulo ("cheio de graça") refletirem-se em sua aparência externa (aparência de anjo), o que não acontece nessas listas. E o mesmo pesquisador apresenta uma comparação entre a descrição de Paulo em APT e as características que o apóstolo aponta de si mesmo em 2 Coríntios $10 .{ }^{67}$ Diversas pesquisas buscaram identificar uma aplicação da fisiognomia

\footnotetext{
${ }^{63}$ Capa curta, presa em um dos ombros e característica dos jovens cavaleiros. Cf. apêndice 1, seção 26, clâmide. Department of Greek and Roman Art. "Ancient Greek Dress." In Heilbrunn Timeline of Art History. New York: The Metropolitan Museum of Art, 2000. Disponível em <https://www.metmuseum.org/toah/hd/grdr/hd_grdr.htm> consultado em 20/12/2018.

${ }^{64}$ Com exceção de "sadio" as características físicas não são positivas. "Cheio de graça" e eventualmente “tendo a aparência de anjo" já parecem pertencer mais às categorias espirituais e de personalidade.

${ }^{65}$ Entre os estudiosos atuais o único ponto de consenso, ao que parece, é que essa descrição não é realista, ou seja, não se trata de um retrato confiável do apóstolo Paulo.

${ }^{66}$ Cf. PERVO 2014, p. 91 e 92; BOLLÓK, 1996 p. 3-5; SÁNCHEZ (2013, p. 88 e 89).

67 Cf. SÁNCHEZ, 2013, p. 89, que apresenta um resumo dessa proposta de Bollok.
} 
na construção da imagem de Paulo. ${ }^{68}$ Mas muitas vezes as interpretações dos dados são contraditórias e questionáveis. ${ }^{69}$ Há também quem veja uma inspiração para essa passagem de $A P T$ em um fragmento de Arquíloco (114W) que retrata um general, cuja aparência deixa a desejar, mas que se revela corajoso, num caso claro em que se opõem essência e aparência. Uma postura bastante plausível é a de Bremmer (1996, p. 39), para quem a explicação é bem simples:

“A razão para as características negativas está provavelmente nos capítulos seguintes nos quais Tecla é retratada como hipnotizada pela mensagem de Paulo. Se Paulo tivesse sido descrito como fisicamente atrativo, a fascinação dela teria sido facilmente compreendida. No entanto, essa descrição induz o leitor a olhar para uma direção diferente. A caracterização, então, é motivada pelo próprio texto $[\ldots] "{ }^{70}$

Em uma abordagem mais recente, Soares (2017, p. 119) soma o conceito bakhtiniano de corpo grotesco ao estudo de Zanker sobre a compreensão da imagem de Sócrates e Sileno na antiguidade (ambos representando os questionadores do ideal de virtude cosmopolita) para propor a descrição de Paulo não como a de um defensor da sociedade patriarcal, mas como a de "um crítico do ideal de virtude da pólis grecoromana" ao "encorajar as mulheres a não se submeterem à lógica do casamento como dever civil”. Pervo também associa a descrição de Paulo à de Sócrates e acrescenta a de Esopo, dois ícones da sabedoria na antiguidade cuja aparência contraria o modelo clássico da correlação entre virtude e beleza. Ambos são retratados como pouco próximos da beleza, sendo que a descrição do último em $O$ Romance de Esopo o distancia bastante dela. $^{71}$ Assim, o pesquisador americano conclui que "semelhantemente, o apóstolo descrito em $A P$ não precisa ser bonito para possuir qualidades admiráveis" $(2014,93) .{ }^{72}$

\footnotetext{
${ }^{68}$ Nas palavras de Soares (2017, p. 86), “os fisiognômicos acreditavam que a análise meticulosa do corpo humano oferecia elementos que denunciassem as disposições internas e o caráter de uma pessoa, todos avaliados a partir da ecfráse kalokagáthica, o ideal de virtude cosmopolita".

${ }^{69}$ Cf. PERVO, 2014, p. 92, BULLÓK, 1996, p. 9.

${ }^{70}$ Note-se, em apoio a essa hipótese, que a jovem é seduzida pelo discurso do apóstolo, a quem pode escutar de sua janela, mas que não pode divisar.

71 "Repugnante ao olhar, ele era asqueroso: pançudo, cabeçudo, de nariz achatado, corcunda, negro, baixote, de braços curtos, manco, vesgo, beiçudo - uma aberração manifesta". Tradução de Adriane S. Duarte em Esopo. Fábulas seguidas do Romance de Esopo. Tradução e apresentação por Malta, A. e Duarte, A. S. São Paulo: Editora 34, 2017.

72 Outra abordagem possível, sugerida pelo professor Milton Torres durante minha defesa desta dissertação, seria a identificação do apóstolo com a figura de Jesus, a quem se atribui o cumprimento da profecia de Isaías 53:2 e 3, especialmente no momento de sua crucificação: “ Ele não tinha qualquer beleza ou
} 
Que o leitor encontre tais "qualidades admiráveis" faz parte das estratégias de caracterização do personagem Paulo, assim como de outros. Koen De Temmerman (2014, p. 6 e 7), buscando compreender a construção dos personagens dos romances gregos, apoia-se nos princípios da retórica antiga e foca sua obra, Crafting Characters, sobre duas questões a esse respeito: “(1) como (i.e. através do uso de quais técnicas narrativas) as características ou traços [...] são atribuídos aos personagens ao longo do texto narrativo e (2) qual o efeito disso?" Ele também se propõe a testar três outras questões interdependentes. "Os protagonistas são descritos primariamente como personagens típicos ou, ao invés, mostram sinais de individuação? [...] Eles são lidos como figuras ideais ou sua descrição mostra traços de realismo? E, finalmente, eles permanecem estáticos ao longo da narrativa ou mostram mudança de caráter?" Para o estudioso, a maneira como um personagem é construído nunca é neutra e, mesmo que o autor ou leitor não tenha estudado as técnicas de caracterização é capaz de utilizá-las ou de entendê-las porque estão presentes na vida real. ${ }^{73}$ Essas técnicas (teorizadas a partir dos antigos tratados de retórica) podem ser resumidas de acordo com o seguinte esquema, encontrado na página 41, da obra de De Temmerman:

1. Nome e antonomásia;

2. Caracterização direta;

3. Caracterização indireta:

3.1 Caracterização metafórica: comparação e paradigma;

3.2 Caracterização metonímica: emoções, adesão a um grupo específico (macrosocial, micro-social, educativo-intelectual), ações, fala e aparência (guiada pela fisiognomia: características físicas invariáveis);

3.3 Definição (metonímica ou metaforicamente relevante).

De Temmerman examinou como os autores do romance grego antigo se serviram dessas técnicas para a construção de seus protagonistas. Essas mesmas técnicas podem ser aplicadas para a análise dos personagens de $A P T$, apesar das diferenças marcantes entre estes e os romances? Seriam um auxílio na compreensão de APT? Para tirar a

majestade que nos atraísse, nada em sua aparência para que o desejássemos. Foi desprezado e rejeitado pelos homens, um homem de tristeza e familiarizado com o sofrimento. Como alguém de quem os homens escondem o rosto, foi desprezado, e nós não o tínhamos em estima." A seção 21, na qual Jesus é identificado por Tecla na aparência de Paulo, atesta a plausibilidade dessa proposta, a qual abre espaço para novas pesquisas acerca da relação entre $A P T$, o romance grego e o texto canônico.

73 "De fato, marcadores de caráter como ação, fala e comportamento tiveram um papel importante na vida social real como técnicas de auto-apresentação, bem como inferência de caráter" (DE TEMMERMAN, 2014, p. 32). 
dúvida, passamos, agora, a abordar a construção dos personagens Paulo e Tecla, focalizando especialmente a caracterização indireta, ${ }^{74}$ na busca de uma melhor compreensão da própria narrativa.

A apresentação dos protagonistas de $A P T$ contrasta bastante com a emblemática introdução dos mesmos nos romances gregos, nos quais um jovem e uma jovem, belos e nobres são tomados de paixão à primeira vista. Em Quéreas e Calírroe, narrativa que é tida como inaugural do gênero, a origem nobre (eugeneia) e a beleza extraordinária do par central (características ideais para os protagonistas dos romances), são apresentadas de imediato. A aparência excepcionalmente bela dos dois é ilustrada por paradigmas da esfera divina (Afrodite, para Calírroe) e da mitologia e historiografia (Aquiles, Nereu, Hipólito e Alcebíades, para Quéreas). Pouco depois dessas alusões, o belo par se encontra e é tomado por paixão.

Em oposição, Paulo é apresentado na primeira seção, sem explicações diretas acerca de sua identidade. Para o narrador elas são desnecessárias, tanto por $A P T$ estar inserido em $A P$, de modo que o encontro entre o apóstolo e Tecla seria uma continuação de suas aventuras, quanto por ser uma personalidade célebre no meio cristão. Basta o nome, de onde ele vinha (Antioquia), porque vinha (fuga da perseguição), para onde ia (Icônio) e o que estava fazendo em sua viagem (compartilhando os ensinamentos de Cristo para seus companheiros de viagem). O vínculo com a tradição cristã a respeito de Paulo é imediato. Outro indício de identificação está nos nomes dos personagens com quem o apóstolo se relaciona logo de início (Demas ${ }^{75}$, Hermógenes ${ }^{76}$ e Onesíforo ${ }^{77}$ ), todos eles ligados a episódios da vida de Paulo, registrados nas agora chamadas cartas pastorais, mas que podiam pertencer a tradições orais da época também. As primeiras ações do protagonista de $A P T$ já ajudam a construir, para o leitor, os traços de abnegação e bondade de seu caráter: Paulo não faz mal a seus inimigos, antes lhes adoça os ensinamentos (procura tornar o ensino agradável). Com todos esses dados, realmente não é preciso explicitar a identidade do personagem. Para o leitor da época, inteirado acerca do cristianismo, não há dúvida: o Paulo apresentado no texto refere-se ao apóstolo de Cristo, o mesmo das tradições orais e escritas que circulam no meio cristão.

\footnotetext{
${ }^{74}$ Como já antecipado, a caracterização direta é exígua nessa obra, ressaltando-se a descrição de Paulo.

${ }^{75}$ Cf. Colossenses 4:14; Filemon 24; 2 Timóteo 4:10.

${ }^{76}$ Cf. 2 Timóteo $1: 15$.

${ }^{77}$ Cf. 2 Timoteo 1:16-18; 2 Timóteo 4:19.
} 
O roteiro típico de um AAA narra as aventuras missionárias de um apóstolo desde sua conversão até o martírio, passando por perseguições e eventos extraordinários (curas, ressurreição de mortos, livramentos sobrenaturais, animais falantes, por exemplo). Nesse sentido, o protagonista de $A P$ pode ser considerado um personagem típico. O indício de individuação mais acentuado em $A P T$ seria a detalhada descrição de seus traços corporais e faciais, um raro expediente tanto nos AAA quanto no romance antigo. Como vimos anteriormente, a compleição física de Paulo descrita na seção 3 de APT não é das mais atraentes. No entanto, há algo em seu interior que se reflete em sua aparência e o torna

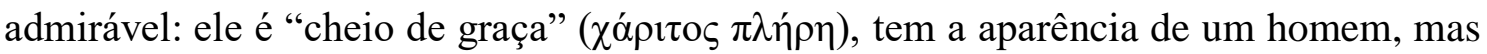
sua face pode se tornar a de um anjo ( $\dot{\gamma} \gamma \gamma \varepsilon \dot{\lambda}$ ov $\pi \rho o ́ \sigma \omega \pi \mathrm{ov}$ ). Esses atributos ilustram a missão divina do apóstolo e indicam que ele tem poderes mais que humanos (embora estes não sejam empregados nos episódios de $A P T)$. Alguns estudiosos encontram aqui uma identificação com Estêvão (Atos 6:8 e 15), o corajoso primeiro mártir cristão, cujo apedrejamento é testemunhado e aprovado por Saulo, o perseguidor dos discípulos de Jesus que mais tarde se tornará o perseguido apóstolo Paulo. ${ }^{78}$

Em oposição ao caráter idealizado de servo de Deus apresentado até aqui, o narrador apresenta as perspectivas de outros personagens, o que ajuda a construir o enredo e mover a narrativa em direção ao seu desfecho. Teóclia o vê como o "homem estrangeiro que ensina palavras falsas e ardilosas". Ele está subvertendo a ordem da cidade através do ensino de ideias contrárias aos costumes da comunidade. Além disso, suas palavras exercem poder dominador sobre Tecla (seções 8 e 9). A visão de Tamiris é perfeitamente compreensível para sua situação de noivo desprezado: o recém-chegado pregador é uma ameaça, pois "engana as almas dos jovens e engoda virgens, para que não se casem, mas permaneçam assim" (seção 12). E os traidores do apóstolo reforçam a aversão do pretendente de Tecla, afirmando que, através de seu ensino, Paulo "despoja os jovens de suas esposas e as virgens de seus maridos" (seção 12). Já a multidão o vê como feiticeiro (seção 15). Isso, mais a denúncia de que ele impede as virgens de se casarem, apresentam ao governador Castélio um estrangeiro sobre quem pesam graves acusações. Em contrapartida a esses olhares desfavoráveis, quando Tecla procura por seu amado pregador entre a multidão que assistirá a seu martírio (seção 21), Jesus se manifesta a ela na aparência de Paulo e depois parte para o céu, numa clara identificação do apóstolo com o âmbito do divino e celestial.

\footnotetext{
${ }^{78}$ Cf. SÁNCHEZ (2013, p. 88); PERVO (2014, p. 94s); BARRIER (2008, p. 113).
} 
Também as falas do próprio apóstolo se revelam mais um recurso para confirmar a sua imagem positiva, de homem bom, a serviço de Deus, em harmonia com as vozes do narrador e de Onesíforo. Na casa deste, Paulo profere um discurso que mescla afirmações que encorajam a encrateia ${ }^{79}$ com citações do célebre Sermão da Montanha, pronunciado por Jesus. ${ }^{80}$ Ao defender-se diante do tribunal de Castélio (seção 17), Paulo apresenta-se como alguém enviado por Deus (

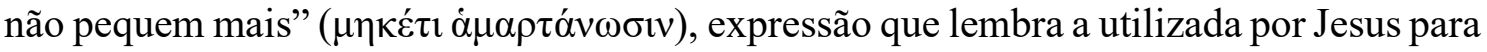
se dirigir à mulher pecadora, a quem ele havia salvo da morte por apedrejamento, e ao

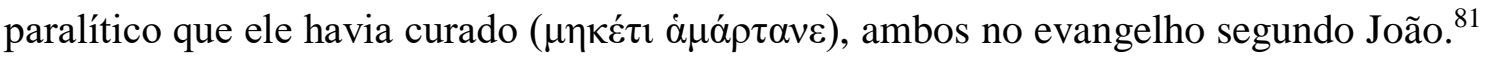
Para o leitor familiarizado com a tradição cristã, tanto sua pregação na casa de Onesíforo, quanto sua defesa diante do governador são extremamente significativos, pois indicam que o protagonista não só conhece os episódios da vida e ensinamentos de Cristo, como domina a linguagem de transmissão dos mesmos. Portanto, ele está preparado para transmiti-los e tem a autoridade para fazê-lo, visto que é um "enviado" de Deus. Além disso, Paulo é apresentado como um orador eloquente, atraindo muitos ouvintes e produzindo um efeito profundo em seu público. É por ouvi-lo que Tecla não consegue se afastar da janela.

Expulso da cidade enquanto Tecla é condenada à fogueira, o apóstolo reaparece na seção 23, que continua reforçando o caráter "cheio de graça", introduzido na seção 3. Ele está em uma tumba vazia, fora da cidade de Icônio, juntamente com Onesíforo e sua família, jejuando e orando por Tecla há seis dias. As crianças estão com fome, mas não há comida. Paulo não tem dinheiro, mas tem uma capa, a qual ele prontamente entrega para um dos meninos trocar por pão. Essa ação benevolente remete a sua caracterização na seção 3 como "cheio de graça" e a seu caráter celestial, indicado pela "face de anjo". ${ }^{82}$

\footnotetext{
79 Domínio próprio, moderação. Sánchez considera que a defesa da abstinência e a ênfase no domínio próprio são demonstrações do caráter moderadamente encratista da obra. Cf. SÁNCHEZ (2013, p. 133). Para uma visão oposta, cf. DUNN, (2006, p. 69-88). Por essa época, provavelmente o encratismo, como movimento religioso, ainda estivesse em desenvolvimento. Mas, a grosso modo, pode ser definido como uma doutrina adotada por certos ramos do cristianismo primitivo a qual pregava o autocontrole, propondo a abstinência de carne e vinho e condenando as relações sexuais, até mesmo dentro do casamento. Curiosamente, Orígenes diz que os encratistas não aceitavam as cartas de Paulo: "Há seitas heréticas que não aceitam as epístolas do apóstolo Paulo: como as duas seitas dos ebionitas e os que são denominados encratitas" (Livro V, 65 - traduzido do texto em inglês, disponível em http://www.newadvent.org/fathers/04165.htm. Acesso em 22/01/2019). Para mais citações da patrística, cf. apêndice 1, seção 5. Encratismo.

${ }^{80}$ Cf. Mateus 5:1-12 e Lucas 6:20-23.

${ }^{81}$ João 8:11 e João 5:14, respectivamente.

${ }^{82}$ Uma das acepções de "graça" é misericórdia, disposição em favorecer outros. Como caráter celestial, quero dizer, como o dos seres divinos (o anjo citado no texto), cuja atribuição maior, no universo cristão, é servir à humanidade.
} 
Quando chega ao túmulo, trazida pelo filho de Onesíforo, Tecla encontra o amado apóstolo orando fervorosamente em seu favor. Embora um pouco bizarra, a passagem em que o apóstolo se encontra orando por seis dias para que o fogo não toque a estimada seguidora (como se a cena do martírio pudesse ser congelada por todo esse tempo) enfatiza seu caráter piedoso, de homem de oração.

Após o reencontro e a celebração do mesmo, Paulo e Tecla se dirigem para Antioquia (seção 26), onde a jovem ascenderá definitivamente ao papel de protagonista principal da obra. Diante do assédio de Alexandre, que interpela Paulo, o homem que a acompanhava, o apóstolo nega conhecer Tecla e simplesmente desaparece, numa intrigante atitude que, aparentemente, destoa bastante da imagem positiva tão cuidadosamente construída até o momento pelo narrador. Para Sánchez (2013. p. 170, 171), a explicação está em paralelos com episódios da vida de Jesus. Na cena dentro da prisão, Paulo representaria Jesus, e Tecla, a Maria, que se senta aos pés de seu mestre para ouvir-lhe os ensinamentos. ${ }^{83}$ Os papéis se inverteriam no incidente em Antioquia, no qual Tecla espelharia Jesus e Paulo ${ }^{84}$, a Pedro, que o negou. O problema é que, embora a semelhança entre a passagem de $A P T$ e a de Mateus seja notável, tornando plausível a proposta do pesquisador espanhol, a mudança na caracterização de Paulo ainda não é explicada. Por que atribuir ao apóstolo, tão celestial que às vezes tinha "a face de um anjo", uma ação reconhecida amplamente como vergonhosa covardia ${ }^{85}$ Já Barrier (2008, p. 225, 226) entende que essa cena reflete as estratégias dos protagonistas dos romances, os quais às vezes se servem de mentiras a fim de escapar de uma ameça e ganhar tempo para encontrar a solução. ${ }^{86}$ Mas pode um servo de Deus, que prega o abandono do pecado, servir-se da mentira para escapar de um problema enquanto deixa a fiel seguidora à mercê de tal perigo para seu novo projeto de vida (manter-se casta)? Pervo (2014, p. 149) também procura uma explicação, considerando que “o resultado deste episódio é vindicar

\footnotetext{
${ }^{83}$ Sánchez tem em mente a passagem de Lucas 10:39, que se assemelha bastante à seção 18 de $A P T$ : "E tinha esta uma irmã chamada Maria, a qual, assentando-se também aos pés de Jesus, ouvia a sua palavra".

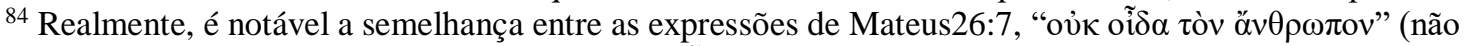

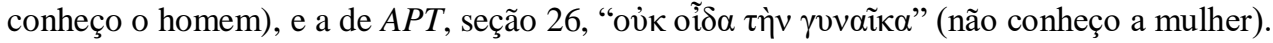

85 Todos os evangelhos narram esse episódio, o que demonstra sua divulgação (Mateus 26: 69-75; Marcos 14:66-72; Lucas 22:56-62 e João 18:15 e 18, 25-27).

${ }^{86}$ Para justificar sua hipótese, o pesquisador cita o exemplo de Caricleia e Teágenes, protagonistas de As etiópicas, de Heliodoro. Ambos mentem regularmente durante suas jornadas sobre a relação entre eles, dizendo que são apenas irmãos, evitando que o ciúme de outros pretendentes se configure em risco de vida para eles. Essa tática de sobrevivência, digamos assim, é parecida com a adotada por Abraão e Sara (Gênesis 20:1-18), Isaque e Rebeca (Gênesis 26:6-8) e não passa despercebida a Barrier, que ainda compara o episódio ao abandono de Dido por Eneas e de Ariadne por Teseu, sendo que, no caso de APT, o enredo segue a personagem feminina.
} 
a afirmação de Paulo de que Tecla tem uma aparência boa demais para esta ocupação [ajudante do apóstolo]". No entanto, a meu ver, isso não justifica o fato de ele tê-la abandonado à própria sorte.

Não faltam outras explicações. Ramsay entende que a presença de Paulo em Antioquia foi uma inabilidade do compilador e que o apóstolo não estava presente no conto original, ${ }^{87}$ pelo menos não nesse episódio. Nesse caso, Tecla teria chamado por Paulo em sua angústia diante do assédio de Alexandre, e o autor, não entendendo isso, acrescentou a presença de Paulo ali. O arqueólogo ironiza: "Tecla, quando foi agarrada pelos assistentes de Alexandre, chamou por Paulo em sua angústia; e a estúpida inteligência de tempos posteriores, pensou que isso implicava sua presença corporal" (RAMSAY, 1893, p. 395). Uma sugestão, também bastante plausível, é a de que, para evitar o estranhamento da ausência de Paulo em uma parte considerável da obra que pretende engrandecê-lo, o tal presbítero tenha sentido a necessidade de seu personagem acompanhar a moça em sua primeira missão. Nesse caso, ele a deixa só porque confia que Deus intercederá por ela, ou seja, lhe é dada uma oportunidade de pôr-se à prova e mostrar-se também "cheia de graça". Isso pode estar conectado ao temor que Paulo expressa (seção 25), de que ela talvez não resistisse a uma provação maior que a primeira (a condenação à fogueira).

Por outro lado, acho válido lembrar que a chegada dele a Icônio se deve a uma fuga de Antioquia. Não levando em conta de qual Antioquia ele vinha e as razões de sua fuga, o fato é que ele estava fugindo e ao chegar a Icônio começa seu trabalho de pregação no interior da casa de Onesíforo. No final de $A P T$, Tecla o encontra em outra cidade, Mira, pregando a Palavra, aparentemente hospedado na casa de Hermeu, o que parece ser uma repetição do início do enredo. Portanto, a fuga de uma cidade para outra quando exposto a perigo, pode fazer parte da caracterização desse personagem, de modo que sua fuga de Antioquia não indique qualquer mudança em seu modus operandi. ${ }^{88}$ Outra possibilidade seria uma aplicação também pouco hábil do típico protagonista masculino dos romances de amor, que, em geral, é menos ativo que a respectiva heroína. No entanto, é preciso admitir, nenhuma dessas opções explica de modo satisfatório o desaparecimento

\footnotetext{
${ }^{87}$ É bom lembrar que Ramsay acredita em um conto original, editado posteriormente.

${ }^{88}$ Isso também pode ser coerente com o ensino de Jesus em Mateus 10:23: "Quando, pois, vos perseguirem nesta cidade, fugi para outra". No entanto, não se harmoniza com a imagem de Paulo em Atos. Neste, posto que tenha fugido de perseguições em Éfeso, por exemplo, quando os artesãos tumultuaram e arrastaram os companheiros de Paulo para o teatro, este se propôs a enfrentar a multidão, no que foi impedido pelos discípulos. Ele deixou a cidade após o alvoroço passar, quando seus amigos já estavam livres de perigo, e não partiu sem antes encorajar os discípulos. Cf. Atos 19:29-41; 20:1.
} 
de Paulo no momento em que Tecla é exposta a um grande risco e a impressão que fica é que o apóstolo não foi tão "angélico" quanto antes, ainda mais que ele foi encontrado dias depois em outra cidade, aparentemente em sua rotina normal de pregações (onde foram parar as orações e jejuns por Tecla?). Nesse sentido, acidental ou intencionalmente, a construção desse personagem sofre um revés.

De qualquer forma, Paulo desaparece, deixando todo o espaço livre para que a heroína brilhe plenamente na narrativa como resultado de seu preparo durante a trajetória do ciclo anterior.

Diferente dos romances antigos, nos quais os protagonistas não demoram a ter seu primeiro encontro, Tecla entra em cena apenas na seção 7 e ambos (Paulo e ela) só se veem na seção 18 , quando a jovem suborna um guarda e penetra na cela do apóstolo para ouvi-lo pregar. Como já visto, as descrições na obra são bastante escassas. ${ }^{89} \mathrm{~A}$ idade da moça não é mencionada e de sua aparência o único indício é a beleza, nunca registrada na voz do narrador, mas reiterada pelas palavras e ações de outros personagens: em uma conversa com Tecla, Paulo a qualifica como uma mulher bonita ( $\sigma \grave{~ \varepsilon u ̈ \mu o \rho \varphi o s) ; ~ n a ~ s e c ̧ a ̃ o ~}$

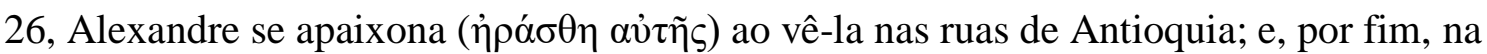

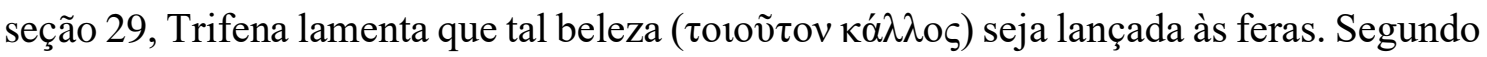
os princípios da fisiognomia, a aparência é um reflexo das disposições interiores e do próprio caráter. No entanto, semelhante aos romances, o narrador não fornece uma descrição das feições da jovem, recusando ou ignorando tais princípios como técnica de construção do personagem. Seus recursos são outros.

“Tecla, uma virgem" (seção 7), eis a primeira definição da personagem, que é extremamente relevante para o desenrolar do enredo, como o narrador bem sabe. Ela é virgem e está ouvindo a pregação de Paulo sobre castidade. No entanto, antes de saber de sua fascinação pelo discurso do apóstolo, somos informados de que ela é noiva. Ou seja, destinada a deixar seu estado virginal. Algo da tensão posterior já começa a se sentir. $\mathrm{O}$ noivado com Tamiris, um membro da elite em Icônio, indica que donzela pertence à classe social mais privilegiada, fato confirmado por sua declaração a Alexandre: "Eu sou uma principal ( $\pi \rho \omega ́ \tau \eta)$ de Icônio" (seção 26). Isso a enquadra, juntamente com sua beleza, entre os personagens típicos dos romances, que tendem a ser idealizados enquanto jovens, belos e de família proeminente na cidade. Ela é uma moça educada e, portanto, conhece

\footnotetext{
${ }^{89}$ No romance antigo as descrições também são exíguas. Em Quéreas e Calírroe, a beleza da heroína é comparada à de Afrodite, mas nada de concreto é dito sobre sua aparência, como cor dos olhos ou do cabelo, idade, etc.
} 
as convenções da sociedade quanto ao que se espera dela. Também é calada. Seu silêncio, a princípio, pode indicar uma forma de rebeldia e agressividade, mas não é improvável que revele um comportamento reservado, posto que decidido. Enquanto está atenta aos discursos de Paulo, parece estar com a mente distante demais para ouvir os rogos de sua mãe e de Tamiris. Esse silêncio pode ser interpretado como fascinação e paixão (páthos erothikon), como sua mãe quer dar a entender. Mas, além do encanto produzido pelo eloquente discurso de Paulo, é possível também supor uma indisposição para argumentar, uma introspecção que não deseja entrar em conflito verbal, pelo menos não naquele momento. ${ }^{90}$ As pessoas caladas costumam ser extremamente observadoras e de reflexões profundas. Será que o leitor de APT pode inferir isso dessa passagem?

Em contraste, Paulo tem uma capacidade extraordinária para falar (sua pregação na casa de Onesíforo segue por três dias...). Da janela de sua casa, Tecla só escuta. Mas é possível que nesse período de tempo, a atividade dela não tenha se reduzido a ouvir. Quando foi tomada a decisão de seguir os ensinamentos do homem a quem ouvia tão atentamente? Seria a recusa aos alimentos apenas fruto de uma paixão ou poderia ser interpretada também como uma demonstração de arrependimento e penitência, como bem coloca Ipiranga Junior? ${ }^{91}$ Será que enquanto seu silêncio desconcertava a família e o noivo, ela não estava em processo mental ativo, refletindo sobre o que ouvia da casa vizinha, arrependendo-se e se penitenciando?

De qualquer forma, ela está fascinada, mas não alienada. Calada, mas atenta, não lhe escapa a condição de Paulo após a denúncia de Tamiris. Ela entende que o apóstolo está preso e sabe como conseguir a entrada em sua cela. No entanto, isso representa um rompimento com a ordem estabelecida. Uma moça honrada não sai sozinha pela cidade durante a noite, muito menos visita a cela de um estranho prisioneiro que, além de tudo, é acusado de corromper as mulheres. Uma atitude assim tem consequências inevitáveis e duradouras. E quem esperaria isso de uma moça educada? Mas ela resolve enfrentá-las demonstrando grande convicção e uma coragem surpreendente. Na cela, a cena se modifica. Ela está sentada aos pés de Paulo, ouvindo-o, como Maria aos pés de Jesus, em

\footnotetext{
${ }^{90} \mathrm{Na}$ seção 43 , ouvimos Tecla dirigir-se pela primeira vez a sua mãe, e a maneira como se expressa demonstra carinho e consideração. Por isso, seu silêncio na seção 7 e 8 pode significar mais que uma rebeldia, mas uma expressão de firmeza inabalável, conjugada a uma índole retraída, de poucas palavras. 91 "O páthos aqui retratado adquire assim uma conformação mista: por um lado, diz respeito à paixão amorosa, em função de uma interpretação relativa ao imaginário dos leitores de romances; por outro,diz respeito à afecção própria do recém-convertido, aqui retratada como alheamento e êxtase, mas podendo vir a ter uma conotação de penitência, sofrimento e arrependimento" (IPIRANGA JUNIOR, 2013, p, 82).
} 
um sinal de humildade, disposição para aprender e reconhecimento da superioridade dele $^{92}$. Embora o narrador não lhe dê voz ainda, seus gestos oferecem mais indícios de seu caráter e sentimentos. Ela beija ternamente as algemas do apóstolo, sinal de gratidão e amor, além de expressar doçura e meiguice. Depois, quando ele é levado para novo julgamento, ela parece ter um ataque de nervos, mas nenhuma palavra é dita. ${ }^{93}$ Interrogada por Castélio, sua resposta se resume a olhar fixamente para Paulo. Diante dos gritos irados da mãe, que pede uma condenação impiedosa, a filha permanece calada. Seu profundo apego a Paulo, bem como seu senso de necessidade de orientação é mais expresso pelo olhar que pela voz: "como a ovelha no deserto olha ao redor em busca do pastor, assim ela procurava Paulo" (seção 21).

Contudo, mesmo como ovelha, Tecla é admiravelmente forte, destemida. E o narrador mostra isso habilmente através dos olhos do governador que, ao vê-la, nua, sendo conduzida ao martírio, "chorou e admirou-se da força que havia nela" (seção 22). A nudez, que não deixa de ter um toque de erotismo, representa uma profunda humilhação e vulnerabilidade, às quais Tecla enfrenta com silenciosa dignidade. Não é preciso forçala a subir à pira, para onde se dirige voluntariamente. Já prestes a enfrentar o terror do fogo, ela faz o sinal da cruz, ${ }^{94}$ confirmando corajosa e obstinadamente sua filiação ao cristianismo. Mais uma vez é um gesto e não a fala que a define.

Essa característica continua ao longo do texto até que sua voz começa gradativamente a aparecer, já perto do final do episódio em Icônio. Na seção 21 Tecla quebra o silêncio: "Como se eu não fosse suportar, Paulo veio contemplar-me." Mas não há um interlocutor definido. O leitor pode deduzir que seja um pensamento ou um breve monólogo do qual apenas o narrador é testemunha. O primeiro diálogo acontece na seção 23, com o filho de Onesíforo. Na 24, ela profere uma curta oração de agradecimento a Deus por seu livramento e por ver Paulo outra vez. $\mathrm{Na} \mathrm{25,} \mathrm{finalmente} \mathrm{expressa}$ verbalmente seu desejo: seguir Paulo em suas jornadas missionárias e receber o batismo.

\footnotetext{
${ }^{92}$ Cf. Lucas 10:39, em que se narra a visita que Jesus faz a duas irmãs de nome Maria e Marta. Maria está tão interessada em ouvir Jesus, que não se importa (ou não se dá conta) que todo o trabalho doméstico tenha sido acumulado sobre Marta. Com esta comparação, o narrador enfatiza o quanto ouvir a Palavra importa para Tecla, indicando também um alheamento ao que é externo a isso.

${ }_{93} \mathrm{O}$ verbo empregado para descrever sua reação, $\kappa 0 \lambda i \omega$, (na voz média significa rolar-se, girar sem cessar, ir e vir, agitar-se) também aparece em Marcos 9:20 referindo-se ao ato do menino endemoninhado se revolver no chão quando foi levado à presença de Jesus. Pode ser uma demonstração de Tecla tenha se angustiado tremendamente pelo que poderia acontecer com seu amado pregador, o que contrasta bastante com sua reação extremamente calma quando recebe a própria sentença.

${ }^{94} \mathrm{Cf}$. apêndice 1 . Seção 22. Sinal da cruz.
} 
Paulo recusa dar-lhe o batismo e ela insiste, mas com brandura, o verbo no imperativo indicando um pedido respeitoso e submisso: "Dê-me apenas o selo de Cristo, e a tentação não me tocará".

Sua verbalização é notavelmente diferente na seção 26. A moça já não é mais a mesma. "A dócil, silenciosa Tecla [do episódio em Icônio] é substituída por uma firme, determinada, ativa e eloquente defensora de sua fé e de seus direitos" (PERVO, 2014, p. 146). ${ }^{95}$ Assediada por Alexandre, que a agarra na rua, ela procura Paulo, aparentemente sem entender o repentino sumiço deste. Mas, isso dura pouco e sua reação é bastante rápida. Dessa vez ela não apenas fala, mas grita seus argumentos de defesa: as convenções da hospitalidade (ela é uma estrangeira), sua condição de serva de Deus

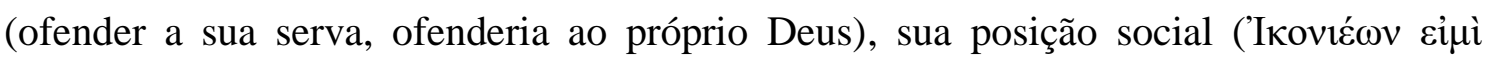

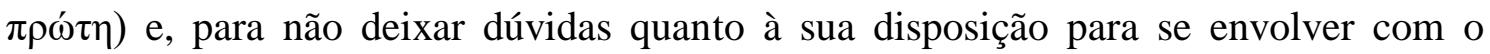
pretendente, ela afirma que foi expulsa de Icônio por não querer se casar.

Para bom entendedor, meia palavra basta. Mas, ao que parece, todas essas palavras não bastaram para convencer Alexandre. $\mathrm{O}$ texto aqui sugere que o nobre siriarca havia tomado a jovem por escrava de Paulo, por isso tinha oferecido dinheiro e presentes ao homem que acompanhava a moça que, além disso, talvez estivesse de cabelo cortado. Escravos não têm direitos, muito menos voz. Alexandre não a solta, ignorando a fala dela. A desprotegida seguidora do apóstolo, então, demonstra uma insuspeita habilidade para a luta. Não somos informados a respeito do tamanho e estrutura física do assediador, tampouco de Tecla. Seja como for, surpreendentemente, ela consegue rasgar o manto dele, derrubar a coroa e talvez até o tenha feito cair já que o texto a apresenta em pé, triunfante (seção 26). Uma imagem que faz vibrar qualquer defensor(a) dos direitos femininos. Como ninguém gosta de ser humilhado publicamente, muito menos um sacerdote imperial, a quem as pessoas respeitam e veneram, o envergonhado oficial do rei se enche de ódio. ${ }^{96}$ Ela o tornou objeto de escárnio e deve ser castigada. Mais uma vez a moça é levada diante de um tribunal, onde, depois de admitir suas ações, é julgada e condenada a lutar com feras.

\footnotetext{
${ }^{95}$ Nessa afirmação de Pervo, penso que a palavra dócil é discutível e talvez apropriada apenas em relação à postura de Tecla quanto a Paulo, visto que, embora calada, ela se impõe diante de Tamiris, da mãe e do governador. O silêncio obstinado e a resistência a deixar a janela sugerem mesmo atos de insubordinação aos desígnios maternos. Em Icônio, ela é tão firme e determinada em seguir Paulo, quanto o é em Antioquia para manter sua fé. A diferença que vejo mais marcante aqui é com relação a sua verbalização. Antes marcada pelo silêncio, agora a moça fala frequente e eloquentemente.

96 Cf. apêndice A, seção 26.
} 
O assediador ainda não está satisfeito, Tecla suspeita, e ele ainda pode tentar conseguir seu primeiro objetivo. No julgamento anterior, o silêncio reinou nos lábios de Tecla. Agora, coerentemente com sua postura corajosa e determinada, ela não exibe um discurso de defesa ou implora por misericórdia. Sua súplica reforça o valor que move a narrativa, a preservação da castidade, e a vincula não apenas às heroínas do romance antigo, mas às protagonistas de outros $\mathrm{AAA} .{ }^{97}$ Embora não haja o registro de suas palavras, certamente foram convincentes, já que conseguiu a tutela da rainha Trifena até a execução da sentença. A próxima fala registrada de Tecla é uma oração, a pedido de Trifena, em favor da filha desta que, falecida recentemente, aparecera em sonho à mãe (seção 29). Outra oração é proferida por Tecla em favor de Trifena, dessa vez de modo espontâneo, a qual ela faz "chorando amargamente" (seção 31). Mais uma vez, a importância da castidade é enfatizada pela jovem mártir que pede a Deus uma recompensa para a rainha, cuja ajuda assegurou que a jovem se conservasse casta. É uma oração emocionada, semelhante à de Paulo na tumba, na qual ele pedia para que Deus protegesse a moça do fogo.

E por falar no apóstolo, o narrador não mais o menciona. Quando levada à arena, ao contrário de seu primeiro martírio, Tecla não o procura novamente entre a multidão, a ovelha à espera dos cuidados do pastor. Ela agora persegue outro objetivo e seu olhar encontra um tanque com água, onde decide batizar-se. Enquanto as mulheres presentes no estádio gritam e se agitam, ela está agindo ativamente em direção a seu propósito, demonstrando mais uma vez a bravura de seu caráter. Após escapar de uma sucessão de ataques que causam o desmaio de Trifena, do qual resulta o fim à série de torturas, surge a oportunidade de a bela jovem confessar sua fé e testemunhar de seu Deus. Mostrando que aprendera a arte de se expressar em público, profere um fervoroso discurso, do qual destaco a parte, a meu ver, mais expressiva:

"Eu sou uma serva do Deus vivo. Quanto ao que me cerca, eu cri naquele em quem Deus se agrada, o filho dele. Por isso nem uma das feras me tocou. Pois o mesmo é o único pilar de salvação e fundamento da vida imortal.

\footnotetext{
97 Sanchez (2013, p. 91) resume bem os aspectos comuns, estabelecidos por Del Cerro, entre Tecla e "Maximila nos Atos de André, Drusiana nos de João e Migdônia nos Atos de Tomé: 1) são mulheres da alta sociedade, casadas - prometida, se falamos de Tecla - com personagens importantes na vida política e social de suas cidades; 2) são formosas, capazes de despertar paixões e desejo nos homens; 3) todas convertem-se ao cristianismo; 4) nenhuma delas tem filhos; 5) além da castidade, são piedosas, generosas e discretas; 6) mostram-se muito mais firmes e consistentes de caráter que seus respectivos maridos. No caso de Tecla, a ação que marca toda a história é sua conversão e sua renúncia ao matrimônio".
} 
É refúgio para quem está em meio à tempestade, um descanso para quem está sobrecarregado, proteção ao desesperado. Em resumo, quem não crer nele não viverá, mas morrerá para sempre" (seção 37).

No martírio anterior, em Icônio, Tecla também é miraculosamente protegida. Mas não há registro de suas palavras. E nem da reação dos que testemunharam seu livramento. A situação agora é diferente. Após seu discurso e mais uma afirmação de fé no poder divino, o governador baixa uma resolução (seção 38) na qual a reconhece como serva de Deus e as mulheres na plateia respondem com gritos de louvor ao Deus de Tecla: "Há um único Deus, o que salvou Tecla”, numa declaração de fé em um único Deus. Tal demonstração de alegria sacode Antioquia inteira. Ou seja, diferente do primeiro livramento, este repercutiu em toda a cidade, demonstrando que o desenvolvimento da protagonista trouxe resultados mais significativos do que em seu estágio inicial.

Outras evidências dessa evolução são encontradas nas últimas seções. Após ser liberta, Tecla volta para a casa de Trifena e continua utilizando com sucesso sua recém desenvolvida habilidade retórica. Ela instrui a rainha e suas criadas, convertendo-as à fé cristã. Ao que tudo indica, falar não é mais um problema para ela. Convencer não lhe é difícil.

A saudade de Paulo a faz procurá-lo mais uma vez. Mas ao encontrá-lo, os papeis iniciais se invertem. No interior da casa onde está hospedado, dessa vez é ele quem ouve admirado as palavras da moça. Na seção 5, quando Paulo chega à residência de Onesíforo, há "grande alegria, e o dobrar dos joelhos, e o partir do pão, e a palavra de Deus..." Agora, os joelhos dos ouvintes se dobram mais uma vez e oram por Trifena, motivados pelas palavras de Tecla (e não do apóstolo). No início de suas aventuras, a jovem foi encontrada sentada aos pés do apóstolo, ouvindo e aprendendo. Agora ela se levanta. Antes, seus olhos o buscavam. Ela precisava de uma direção. Agora, Tecla não pede, informa: "Vou para Icônio". ${ }^{98}$ E dessa vez, as palavras escassas procedem dos lábios de Paulo: "Vá e pregue a Palavra de Deus". Alguns viram aqui uma autorização para pregar. Será que viram algo que não aconteceu? Tertuliano pensava que sim.

Por essa breve análise da caracterização de Tecla pode-se observar que o narrador se serve predominantemente da caracterização indireta para construir essa personagem. O leitor vai sendo apresentado aos poucos a ela. Através do grupo social, entende que ela

\footnotetext{
${ }^{98}$ Para Nogueira (2016, p. 21), "trata-se de uma ousada afirmação de autonomia e autoridade de mulheres no cristianismo paulino".
} 
é rica e educada, como seus pares dos romances de amor. Pelas ações e reações, vê uma jovem de grande determinação e coragem, capaz de enfrentar a tortura e morte sem se aterrorizar com isso, numa evidente idealização da personagem. Seu silêncio diante dos apelos da mãe, de Tamiris e do governador, indica, além do evidente páthos característico dos romances e de uma possível indisposição para discussões, também traços de insubmissão para com aqueles que intentam impedi-la de seguir seu propósito. No entanto, para com Paulo ela se mostra meiga, dócil, respeitosa e, de início, dependente, o que é figuradamente comunicado ao leitor através da imagem da ovelha buscando o pastor (seção 21). Calada na maior parte do episódio em Icônio, Tecla vai evoluindo na fala e nas ações, até que a partir da seção 26 ela sai da órbita de Paulo e termina por assumir sua própria missão. O reencontro com a mãe é a demonstração definitiva de seu desenvolvimento. Paulo lhe diz para (ou a autoriza a) pregar a Palavra. E sua mãe é a primeira pessoa a quem Tecla se dirige. $\mathrm{O}$ apelo é feito com tom carinhoso, mostrando preocupação com a salvação e as necessidades financeiras e emocionais da mãe, sem qualquer indício de rancor. No entanto, inversamente, desta vez é para Teóclia que o narrador não dá voz. A filha fala e a mãe se cala. Não sabemos qual a natureza desse silêncio. O fato é que a decisão da senhora fica em suspenso para o leitor. Cumprida a missão com a mãe, a heroína cristã parte mais uma vez de casa, não às escondidas, mas com plena liberdade e autonomia. Não para buscar mais luz, aprendendo aos pés de Paulo, mas para "iluminar a muitos" (seção 43). A aprendiz se torna mestra. E confrontando essa última imagem com a primeira, a da fascinada ouvinte de Paulo à janela, temos que admitir que houve uma evolução e tanto. 


\title{
CAPÍTULO 3
}

\section{Atos de Paulo e Tecla e o romance antigo}

\begin{abstract}
"Pois há três dias e três noites que Tecla não se levanta da janela, nem para comer, nem para beber, mas, com o olhar absorto, como se estivesse fascinada..." (Atos de Paulo e Tecla, seção 8).
\end{abstract}

\subsection{Os romances antigos ${ }^{99}$}

Os primeiros séculos da Roma imperial, coincidindo com o advento do que se convencionou designar Segunda Sofística, ${ }^{100}$ testemunharam o surgimento de textos narrativos bastante distintos da tradição literária que gozava de prestígio então, dentre os quais os que hoje estão reunidos sob a denominação de romance antigo. Como veremos mais abaixo, a classificação dessa produção não está livre de disputas, mas em geral, ela considera dois grupos principais: os romances de amor ideal (ou romances de amor e aventura) e os cômico-realistas. O primeiro, que recebe destaque nos estudos do gênero, possui um enredo básico (embora comporte algumas variações), narrado em grego, em que um jovem e uma jovem, nobres e de rara beleza, são tomados de paixão à primeira vista e, separados por eventos fortuitos, vivem longe de casa aventuras cheias de perigos, com raptos, viagens, piratas, ladrões e assédio, antes que atinjam o final feliz, configurado pelo reencontro e ditosa vida matrimonial. Os cinco romances gregos que chegaram até nós de forma íntegra ${ }^{101}$ são Quéreas e Calírroe, de Cáriton (I. d.C.); As efesíacas ou Antia e Habrócomes, de Xenofonte de Éfeso (I-II d.C.); Dafnis e Cloé, de Longo (II d.C.); Leucipe e Clitofonte, de Aquiles Tácio (II d.C.); As etiópicas, de Heliodoro (IV d.C.). ${ }^{102}$

Duas outras obras do mesmo período, Satíricon, de Petrônio (I d.C.) e o Asno de Ouro ou Metamorfoses, de Apuleio (II d.C.), formam um segundo grupo, escrito em latim e denominado como "romance cômico-realista". Neles a idealização do amor

\footnotetext{
${ }^{99}$ Em português, já é possível encontrar boa informação sobre o romance antigo. Para uma apresentação do tema e uma bibliografia introdutória, cf. DUARTE (2016), Para um panorama teórico do romance antigo, bem como para a discussão de vários de seus aspectos, cf. IPIRANGA Jr (2014) e SANO (2013a e 2013 b). Para mais uma abordagem sobre a ligação entre romance antigo e os AAA, cf SOARES (2017). Para um estudo mais aprofundado, cf. BRANDÃ̃ (2005).

100 A Segunda Sofística é um movimento cultural que "opera a memória cultural helênica em Roma" (BRENER e MARTINS, 2017, p. 13), dando grande ênfase à retórica.

${ }^{101}$ Outras obras, hoje apenas fragmentárias, podem ser incluídas com maior ou menor grau de acerto, no grupo romance amor ideal.

${ }^{102}$ Cf. DUARTE (2016).
} 
(característico do grupo anterior) é substituída pela sátira e os personagens são retratados com viés mais realista. Outras obras de cunho ficcional são História de Apolônio, rei de Tiro e Romance de Alexandre, ambos com autoria ignoradas.

Para além desses grupos restam ainda textos narrativos em prosa, da mesma época, aos quais faltam ou o componente amoroso ou o viés cômico-realista. São os romances classificados usualmente como "marginais", exemplificados por Das Narrativas Verdadeiras, de Luciano (II d.C.), a Vida de Apolônio de Tiana, de Filóstrato (III d.C.) e os anônimos Romance de Alexandre e Romance de Esopo. Compartilhando o mesmo espaço considerado periférico estão também cartas pseudoepigráficas que desenvolvem a história de personalidades célebres do mundo grego, e os Atos Apócrifos dos Apóstolos, que narram os eventos da vida dos discípulos em sua missão de pregar o evangelho até que terminem sua vida, geralmente pelo martírio. No último grupo, temos cinco obras principais, cujos protagonistas são os apóstolos André, João, Paulo, Pedro e Tomé. Atos de Paulo e Tecla é um dos componentes dos Atos de Paulo e, portanto, no que tange ao gênero, encontra-se à margem do que os estudiosos atuais têm considerado o cânon do romance antigo. ${ }^{103}$

No entanto, a posição dentro ou fora do grupo romance não equivale ao valor ou popularidade atribuídos a essas obras pelo público leitor da antiguidade. Ela representa a visão anacrônica e, possivelmente, imprecisa de estudiosos posteriores. É para isso que Morales (2009, p.6) chama a atenção quando diz que todos os romances antigos são “"fringe' fiction”, já que não foram citados por poetas, estudados nas escolas ou reverenciados pelos críticos - os indícios de centralidade que a autora aponta. Não é difícil concordar com ela de que o termo "fringe", com sua conotação negativa, pode causar uma impressão equivocada de que as obras hoje rotuladas assim eram, em sua época, menos prestigiadas que os romances propriamente ditos, i. e, os que hoje formam o cânone do gênero.

Em realidade, para os pesquisadores dos romances antigos a questão do gênero é um terreno pouco sólido, já que há uma notável ausência de testemunhos dos teóricos da época. Em consequência, uma apreciação mais fundamentada da recepção das obras se torna bastante comprometida. De qualquer forma, justa ou injustamente, o conceito das

\footnotetext{
103 Marginais aos romances gregos e apócrifos em relação aos textos do NT. Com esses rótulos nada elogiosos, os AAA caíram em um tipo de fenda entre os estudos clássicos e os teológicos, o que por muito tempo os tornou desinteressantes para ambas as correntes de estudo. Nogueira (2016, p. 13) lembra que também para os historiadores os AAA são "cristãos demais" para atrair interesse.
} 
ficções gregas antigas alternou-se entre positivo e negativo no decorrer do tempo, trazendo consequências para o desenvolvimento de seus estudos, como veremos a seguir.

\subsubsection{A instável apreciação do gênero}

A apreciação do romance antigo nunca foi uniforme, variando consideravelmente com o passar do tempo. Se hoje presenciamos um aumento considerável de estudiosos debruçados sobre esse gênero, revendo sua trajetória através do tempo perceberemos que ele nem sempre despertou tanto entusiasmo, passando notoriamente por sucessivos altos e baixos. Na Antiguidade temos o testemunho pouco elogioso do imperador Juliano (século IV), que provavelmente se refere aos romances quando diz que "devem ser rejeitadas todas as ficções $(\pi \lambda \alpha ́ \sigma \mu \alpha \tau \alpha)$ compostas por autores do passado na forma de

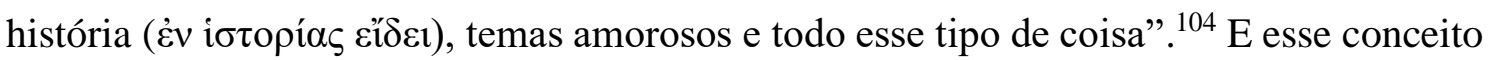
negativo parece perdurar no início do Período Bizantino, como Macróbio, autor do século V, deixa perceber. ${ }^{105}$ Já pelo século XIII, autores que emularam os romances gregos, indicam que a audiência conhecia o romance antigo e podia perceber as alusões a ele nas obras de seus contemporâneos. Burton (2008, p. 280) assinala que durante o período medieval grego houve uma continuidade de leitores do romance antigo, o qual era admirado por seu estilo retórico ainda que a preocupação moral prevalecesse no discurso crítico. E a tendência favorável aos textos se torna bastante positiva durante o Renascimento, ${ }^{106}$ voltando a ser desfavorável apenas no final do século XIX com a publicação de Der Griechische Roman und Seine Vorläufer (1876), de Erwin Rohde, que inaugurou um período no qual a questão mais importante se restringia a buscar a origem do romance a fim de encontrar de que gênero se derivava (o que, de certo modo revelaria sua posição de literatura decadente). ${ }^{107}$

Depois de décadas sob a designação de literatura inferior, a situação inverte-se novamente na segunda metade do século XX, quando Perry (em 1967) e Reardon (em

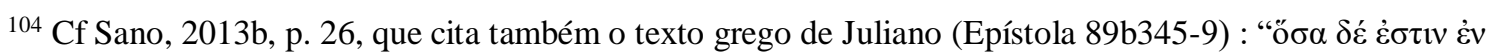

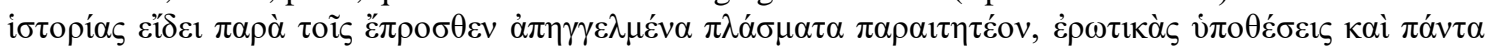
$\dot{\alpha} \pi \lambda \tilde{\omega} \varsigma \tau \grave{\alpha} \tau 01 \alpha \tilde{v} \tau \alpha . "$

105 "O ouvido deleita-se com as comédias do tipo que Menandro e seus imitadores produziram, ou com narrativas realísticas (argumenta) cheias de aventuras fictícias de amantes às quais Petrônio se dedicou e Apuleio (...). Todo esse tipo de histórias (totum fabularum genus), cujo único objetivo é deleitar o ouvido, um tratado filosófico bane de seu santuário" (apud Sano, 2013 a, p. 110 e 111).

106 Sano, 2013b, p. 7.

${ }^{107}$ Ibidem. Cf também Fusillo, 2008, p. 322.
} 
1971) publicam obras que se voltam para além das questões de origem e demonstram a importância do romance antigo para os estudos da cultura grega no contexto do império romano, entre outros aspectos. Desde então, os ventos parecem ter se tornado definitivamente favoráveis ao gênero, cujas pesquisas têm recebido grande impulso. ${ }^{108}$ Em consequência, antes rotuladas como produções inferiores e decadentes em relação às grandes obras da literatura clássica, textos como As efesíacas, Quéreas e Calírroe, Dafnis e Cloé têm despertado cada vez mais interesse acadêmico, ocasionando sucessivas traduções e estudos. Juntamente com elas, as pesquisas em torno dos AAA, que também enfrentaram oscilações de interesse, têm se multiplicado. Se a tendência continuar, seu estudo deve permanecer em alta. Especialmente porque há muitos aspectos que ainda despertam indagações, dentre eles, a maneira como esses textos eram lidos e percebidos no âmbito da poética antiga.

\subsubsection{Teoria}

A teorização do romance antigo envolve mais dúvidas do que certezas. Qual a definição? Como se originou? Como eram os autores e leitores? Quais as motivações? Como se deu a recepção? Devido à ausência de referências ao gênero e às obras que o englobam na Antiguidade, as respostas buscadas hoje para essas perguntas têm suscitado controvérsias, dando espaço para poucas afirmações precisas e muitas suposições. ${ }^{109}$

E as disputas já começam pela denominação. ${ }^{110}$ Nem todos os estudiosos se satisfazem com o termo "romance", 111 por ser um vocábulo bastante associado a produções medievais e da modernidade e, por outro lado, também atribuído aos discursos e produções literárias (muitas vezes em verso) publicadas nas línguas vernáculas (romances) em contraposição aos textos falados e escritos em latim. Aqueles que questionam seu uso raciocinam que, além de não designar corretamente os objetos de estudo, uma obra denominada como romance pode despertar expectativas equivocadas

\footnotetext{
${ }^{108}$ Cf. Sano (2013, p.7).

${ }^{109} \mathrm{E}$ isso é perceptível já no vocabulário das pesquisas, no qual é frequente o emprego de palavras e expressões que denotam a instabilidade do terreno: parece que, pode ser que, provavelmente, possivelmente, é possível que.

${ }^{110}$ Ao que parece, a única certeza a respeito disso entre os estudiosos se refere ao que ele não é (discurso historiográfico, por exemplo). Os termos antigos relacionados os romances não são suficientes para enquadrá-los a algum gênero, como avalia Goldhill: "Logoi, muthoi, graphe, suggramma e mesmo suntagma [...] não fornecem qualquer senso de afiliação genérica específica;” (2008, p. 191).

${ }^{111}$ Cf. Nota de rodapé em HOLZBERG, 2003, p. 11.
} 
nos leitores da atualidade. ${ }^{112}$ Esse argumento não é de todo sem valor, mas, como até o momento, não foi encontrado registro algum da Antiguidade que ofereça uma solução melhor para designar esse conjunto de textos, o termo romance continua em uso (com a variante novel, em língua inglesa), e a querela, sem solução. Holzberg (2003, p. 11) parece propor um fim à discussão ao admitir que "simplesmente não há termos antigos e devemos nos permitir o anacronismo de trabalhar com os modernos".

Se o nome suscita discussões, a delimitação do corpus não fica atrás, já que definir o gênero e as obras que se enquadram nele não é tarefa fácil. Se nos apoiarmos, por exemplo, na definição de gênero de Goldhill113: "um nome para de que modo o que é representativo e típico é codificado" (2008, p. 186), veremos que a dificuldade talvez não esteja tanto em encontrar o que é "representativo e típico" nos textos sobreviventes dos romances, mas em definir os critérios para agrupá-los, o que exige um consenso ainda não alcançado pelos teóricos. Em sua discussão sobre o tema, Holzberg (2003, p. 11 e 12), por exemplo, pontua que é preciso encontrar critérios fixos, para que as narrativas possam ser selecionadas de modo a formar um grupo homogêneo, que constituirá o gênero. No entanto, como reconhece Brandão (2005, p.85), “o romance grego não é [...] um bloco homogêneo, apresentando diferenças estilísticas importantes" e isso problematiza bastante o estudo. Na lista de obras citadas acima, vemos textos em grego e em latim, alguns com predominância da temática amorosa, outros pendendo para o cômico, outros ainda, que não se ajustam em nenhum desses moldes.

Então, quais desses grupos podem ser chamados romance e quais não? A meu ver, a proposta de Brandão (2005, p. 65) de uma definição enxuta, como a de uma narrativa de ficção em prosa, é capaz de abranger todas as obras do corpus sobrevivente ao mesmo tempo em que respeita suas diferenças. ${ }^{114}$ No entanto, pelo grande número de eventos extraordinários constantes nessas narrativas, penso que não seria impróprio adicionar à

\footnotetext{
112 Cf. GOLDHILL, 2008, p.191.

113 Outra opção é a que Morales propõe, de usar para o romance o mesmo argumento de Brooks para o melodrama: "menos um gênero que um modo imaginativo", entendendo "modo imaginativo" como "um modo coerente de imaginar e representar" (Brooks apud MORALES, 2009, p. 10).

${ }^{114}$ Para Ipiranga Jr. (2014, p. 49), "o grande diferencial do trabalho de Jacyntho Lins Brandão em relação aos outros teóricos do romance é de ter tomado como ponto de partida não uma definição do gênero fundamentada nos romances de temática amorosa, mas em uma concepção baseada no conceito de ficcional tal qual aparece na obra de Luciano de Samósata". A proposta de Brandão, altera ligeiramente o corpus do romance grego, incluindo nele, por exemplo, "Das Narrativas Verdadeiras", de Luciano, geralmente contado entre as narrativas comumente ditas "marginais".
} 
definição acima a menção à Týkhe, ${ }^{115}$ que o mesmo autor afirma que "preside a lógica do romance grego" e que, "interferindo nos planos das personagens, torna factível a narração do romance" (BRANDÃO, 2005, p. 222 e 225). Como o plot point dos roteiros de cinema, “ela é o elemento sempre capaz de reverter o rumo da ação" (BRANDÃO, 2005, p. 227). Ainda que o estudioso mencione apenas o romance antigo em sua definição, a presença da Týkhe como agenciadora dos fatos se faz sentir em maior ou menor grau em todas as "narrativas de ficção em prosa". ${ }^{116}$ Posto que aparentemente simples, esta definição apresenta desdobramentos bastante complexos, como expomos na sequência.

Desde a antiguidade as narrativas ficcionais estão presentes na literatura grega. ${ }^{117}$ A novidade do romance está em aliar a ficção, mais relacionada à narrativa em verso (da epopeia e do teatro, por exemplo), à prosa, muito associada ao discurso historiográfico e filosófico, os quais apresentam um caráter utilitário, em nítido contraste com a ficção, cujo fim é o entretenimento. ${ }^{118}$ É o que Brandão (2005, p. 233) procura enfatizar quando diz que:

\begin{abstract}
"[...] o historiador tem necessidade de marcar seu contraponto com o poeta para garantir sua diferença: seu compromisso com a verdade só pode ser representado como recusa da poesia. O romancista, pelo contrário, age na mesma esfera que o poeta, de que se distingue apenas (e isso não é pouco) enquanto escreve em prosa, como os historiadores".
\end{abstract}

Portanto, o romance, ao contaminar a prosa, campo do discurso verdadeiro, com a ficção, provoca um deslocamento do uso daquela. E, ao distanciar-se da historiografia, pela inserção da ficção, estabelece aí uma diferença de finalidade: a de provocar prazer. Nas palavras de Brandão (2005, p. 203), “um prazer decorrente da forma como o narrado se constrói ao longo de livros em que, de maneira variada e surpreendente, se sucedem inúmeras ações, movidas pelo acaso que preside a vida de cada um”.

\footnotetext{
${ }^{115}$ Týkhe aqui pode ser entendida tanto como a sorte personificada em deusa, como por casualidade ou, no caso das obras cristãs, como a Providência.

116 Vejo possível ampliar a definição para "narrativas de ficção em prosa caracterizadas pela intervenção marcante da Týkhe". Contudo, pondo de parte minha ousadia, continuarei aqui usando a definição já clássica do professor da UFMG.

${ }^{117}$ Hesíodo já alude ao tema da ficção na poesia hexamétrica (Cf. Teogonia, 27, 28). No entanto, RuizMontero observa que "tanto a tragédia quanto a comédia foram escritas em verso e não eram consideradas pelos gregos como sendo igualmente ficcionais: apenas a comédia constituía 'ficção pura' " (RUIZMONTERO, 2003, p. 32).

118 Não que a narrativa histórica não seja também fonte de entretenimento e prazer, da mesma forma que a ficção também pode ter caráter utilitário. No entanto, ao contrário do discurso historiográfico, o gênero ficção não está convidando o leitor a confiar em seus relatos.
} 
O uso da prosa, portanto, representa um importante ponto de contato entre o romance e a historiografia. A esse podemos somar outros que facilitarão o cotejo, mais tarde, entre os romances antigos, os AAA e, por fim, APT. Ainda no aspecto formal, é importante notar que o romance e a historiografia são narrativas escritas, ou seja, quanto à recepção, destinam-se à leitura - ainda que essa leitura seja feita para um auditório. Para isso, ambos recorrerão a estratégias próprias do registro escrito, embora retenham traços de oralidade presentes em maior ou menor grau, especialmente na mimese dos discursos. Assim, o romance dialoga com a historiografia e o recurso mais perceptível disto, conforme observa Brandão ${ }^{119}$, é o proêmio, que parece exercer o mesmo fim prático em ambos os gêneros, sendo que no romance, no entanto, se acrescenta a necessidade de representação do próprio narrador. Para efeito de comparação, veja-se a semelhança entre o proêmio da obra de Tucídides e a abertura de Quéreas e Calírroe. "Tucídides, cidadão ateniense, descreveu a guerra entre Peloponésios e Atenienses e a forma como lutaram uns contra os outros" (Th. 1.1); "Eu, Cáriton de Afrodísias, secretário do orador Atenágoras, vou narrar uma história de amor que aconteceu em Siracusa." (CÁRITON, I, 1). ${ }^{120}$

Embora sejam discutíveis, para compreender mais claramente as inovações literárias que o romance trouxe, considero bastante úteis as considerações de Brandão (2005, p. 51 e 52) a respeito de como Aristóteles, em sua Poética, diferencia a narrativa literária (entenda-se por poesia), da narrativa histórica, entre as quais a de que "a primeira refere-se ao universal, ocupando-se do que poderia acontecer, enquanto a segunda se volta para o particular e visa ao acontecido". ${ }^{121}$ Séculos depois surge o romance, um gênero que, para Brandão, trata do particular, porém (ao contrário do que propõe Aristóteles) um particular que não se volta para o que aconteceu, como na historiografia ${ }^{122}$, mas ao que pode acontecer, como na literatura. $\mathrm{Na}$ visão de Brandão, ao incorporar esse traço da narrativa histórica (que trata do particular), o romance o coloca a serviço da ficção, desfazendo assim sua ligação com a forma de que procede. O mesmo sucede quando o

\footnotetext{
${ }^{119}$ Cf. BRANDÃO (2005, p. 110, 112, 163,164).

${ }^{120}$ Bastante pertinente é a observação de Sano $(2015$, p. 79) de que essa introdução não era uma fórmula utilizada pelos historiadores contemporâneos de Cáriton, indicando que esta teria sido uma estratégia de identificação do texto com a época do enredo.

${ }^{121}$ Considero bastante importante essa diferenciação feita por Aristóteles, pois nos oferece um testemunho de como seria o estatuto da ficção na Antiguidade, o que ajuda a identificar mais uma inovação trazida pelo romance.

${ }^{122}$ Aqui refiro-me ao discurso historiográfico já consagrado e difundido desde a Antiguidade Clássica (Tucídides, Heródoto e Políbio, por exemplo).
} 
romance interage com outros gêneros, tais como a epistolografia, a biografia e o diálogo. Ele se apropria de traços de cada um, conforme a necessidade da narrativa, e dando-lhe a própria forma, a que hoje chamamos de romanesca ${ }^{123}$, podendo deste ponto de vista, ser considerado um gênero híbrido. ${ }^{124} \mathrm{Com}$ isso, fica evidente o vínculo do romance antigo com toda a tradição literária o que, se não consegue afastar todo o preconceito aliado ao gênero, pelo menos abre a possibilidade para uma nova perspectiva, a de que não se trata um gênero inferior, raso, medíocre, mas um gênero rico de relações, que reinventou a todos os outros ao inventar-se a si mesmo. E, mais ainda, como afirma Brandão (2005, p. 15), é um fenômeno que, assim como outros dessa ordem, diz algo sobre o humano, ou seja, diz respeito a todos nós.

\section{O romance antigo e os Atos Apócrifos do Apóstolos}

Embora apropriando-se de traços de vários gêneros da tradição literária grega, como vimos acima, o romance antigo floresceu a uma distância temporal considerável dos seus avatares. Algumas narrativas romanceadas já aparecem no segundo século a.C., mas os romances de amor, que hoje ocupam posição preeminente nos estudos do gênero, floresceram a partir do primeiro século d.C. e atingiram seu auge no século II d.C., concomitantes ao desenvolvimento da Segunda Sofística, aparentemente ignorantes ou indiferentes ao surgimento e ascensão do cristianismo e sua literatura, que ocorria em processo simultâneo.

Por essa época, os Evangelhos, Atos e Cartas, que mais tarde comporiam o cânon do Novo Testamento, já estavam escritos há décadas ${ }^{125}$ e, como dissemos anteriormente,

\footnotetext{
${ }^{123}$ Por forma romanesca, entendo suas características básicas: narração ficcional em prosa.

${ }^{124}$ Bakhtin (1998, p. 215) reconhece bem isso ao afirmar que "não se pode negar o conhecido sincretismo dos aspectos de gênero no romance grego. Ele utilizou e fundiu em sua estrutura quase todos os gêneros da literatura clássica". Parece-me relevante o detalhamento desses "aspectos de gênero" que o autor russo expõe anteriormente, no mesmo parágrafo: "Todos os elementos do romance (em sua forma abstrata) [...] encontravam-se e foram bem desenvolvidos em outros gêneros da literatura clássica: os temas de amor (primeiro encontro, paixão à primeira vista, saudade) foram desenvolvidos na poesia helênica, outros temas (tempestades, naufrágios, guerras, raptos) são desenvolvidos pela epopeia clássica, alguns temas (reconhecimento) exerceram papel substancial na tragédia, os temas descritivos foram desenvolvidos no romance geográfico clássico e nas obras historiográficas (por exemplo, a de Heródoto), e as reflexões em gêneros retóricos".

125 “As evidências sugerem que os autógrafos neotestamentários começaram a ser reproduzidos ainda no período apostólico" (Paroschi, 2012, p. 85). No final do século I e meados do II, Clemente, Inácio e Policarpo já citavam porções de textos do que mais tarde seria o NT como tendo a mesma autoridade das Escrituras judaicas, num claro reconhecimento de que consideravam tais textos como sagrados. Cf. I Clemente 13:1-4, Epístola de Inácio aos Magnésios 13:1; Epístola de Inácio aos Esmirnianos 7:2; Epístola
} 
várias obras com temas cristãos ${ }^{126}$ circulavam pelo império, indicando que o registro escrito recebera grande adesão ${ }^{127}$ entre os seguidores do cristianismo. Entre essa produção, voltamos nossa atenção agora para os AAA, já mencionados no capítulo 1 e dos quais faz parte $A P T$, pois, embora abordem temas e personagens do universo cristão, estes apresentam também evidentes vínculos ${ }^{128}$ com o gênero romanesco, sugerindo um intenso diálogo com ele.

As coincidências entre os dois conjuntos de textos começam pela época de composição. Bremmer (2001, p. 157) afirma que a cronologia inicial dos AAA coincide com o auge da produção do romance antigo, meados do século II, como também seu local de composição: Ásia Menor ocidental ${ }^{129}$. Analisando a terminologia social de vários AAA, o estudioso holandês verificou que o termo "o principal da cidade", era característico de Afrodísias e Norte da Lídia, além do leste da Frígia, Bitínia e Pisídia. Portanto, essa pode ser a região de composição de pelo menos dois AAA, Atos de João e Atos de Paulo, já que apresentam essa terminologia.

Outra questão a ser comparada é a autoria das obras. Do grego apókryphos, escondido, o termo inicialmente foi usado para referir-se a textos cuja autoria, local de origem e objetivos eram desconhecidos. ${ }^{130}$ Enquanto a autoria aparece em algumas obras

de Policarpo 3:2-3; 9:1; 11:2-3; disponíveis online em < http://www.earlychristianwritings.com/churchfathers.html > (consultado em 06/01/2019.

${ }^{126}$ Além dos textos que hoje compõem o NT, Vielhauer (2005) lista pelo menos mais 34 obras literárias cristãs dos primeiros dois séculos. Se levarmos em conta que o autor não inclui em seu estudo tratados, sermões e apologias, é fácil concluir que o registro escrito foi uma atividade corrente entre os cristãos primitivos.

${ }^{127}$ Pelo numeroso corpus sobrevivente e pela tradição judaica de utilização das Escrituras (legado ao qual os cristãos deram continuidade), sou levada a concordar com Paroschi (2012, p. 11) de que, embora a tradição oral continuasse exercendo papel relevante, "o cristianismo sempre foi caracterizado por uma profunda identificação com palavra escrita”. Para uma discussão sobre o nível de letramento entre os judeus, de onde veio grande parte dos primeiros cristãos, cf. Paroschi, 2012, p. 10 e 11, onde ele contrapõe dois pesquisadores que se opõem nessa questão: Birger Gerhardsson e Catherine Hezsen.

${ }^{128}$ Rosa Söder, de acordo com Vielhauer (2005, p. 721), enumera cinco elementos fixos que ligariam essas produções cristãs ao romance: "o elemento da migração; o elemento aretológico (descrição de vidas virtuosas); o elemento teratológico (descrição de povos, pessoas, animais e acontecimentos fabulosos); o elemento tendencioso de ordem religiosa, filosófica, política e ética; o elemento erótico". Já Ipiranga Junior (2013, p. 16) identifica tais vínculos como sendo "o pseúdos enquanto princípio ficcional, o páthos erotikón, a paixão amorosa e a ocorrência de paradóxa, fenômenos extraordinários, conduzidos pela mão da fortuna".

${ }^{129}$ Essa também é a posição de Hägg. Cf. 1983, p. 161. Já Barrier (2008, p. 21), considera que ambos os grupos, AAA e romance antigo, floresceram simultaneamente e que, portanto, os AAA não poderiam ser derivados dos romances.

${ }^{130}$ Cf. Pervo, 1996, p. 690 e Hägg, 1983, p. 159. Outras acepções para o termo seria o de obra falsa, não autorizada ou ainda, de acordo com Johnson (2017, p. 670), de conteúdo esotérico. Segundo o pesquisador, o sentido negativo de apócrifo não é moderno, aparecendo em registros do quarto século. No entanto, ele admite que a definição do que seria considerado apócrifo (rejeitado) ou não (tolerado ou aceito) passou por flutuações na antiguidade (Ibidem, p. 761). 
consideradas como romance de amor ideal ${ }^{131}$, nos AAA esse dado não aparece, o que os distancia assinaladamente das obras do cânon romanesco.

Outra diferença relevante entre os dois grupos de obras é que, se por um lado, parte considerável dos romances é redigida em ático e trabalhada

\begin{abstract}
"com os recursos que a tradição clássica fornece, os apócrifos e os escritos do Novo Testamento preferem a koiné, mais próxima da língua falada, com um vocabulário mais limitado, frases declarativas e sintaxe simplificada. Provavelmente, a diferença de composição do romance em face dessa outra literatura denuncia uma destinação diversa: não se trata de um gênero popular; populares tornaram-se sim os escritos cristãos, o que a própria história subsequente comprovou" (BRANDÃO, 2005, p. 214).
\end{abstract}

Assim, pela seleção da língua, os dois grupos de textos revelam finalidades diferentes: enquanto havia um público culto e letrado (pepaideumenos) que se distraía com a leitura de Quéreas e Calírroe e As efesíacas, para citar apenas dois exemplos, havia também leitores para obras como os AAA, que aparentemente tinham maior preocupação com questões espirituais. ${ }^{132}$ Isso leva a distinguir nessas obras um caráter claramente utilitário: embora houvesse o prazer de desfrutar da leitura, como no romance grego, os AAA teriam como fim "oferecer um testemunho de fé, com fins doutrinais" (IPIRANGA JUNIOR, 2013, p. 14). E mesmo nesse contraste ainda podemos entrever uma semelhança na matéria das obras, já que no romance de amor os jovens pares apaixonados são sempre piedosos e reverentes aos deuses, o que parece indicar que este era um valor compartilhado também por seus leitores.

O tema da castidade é muito caro a ambos os conjuntos de textos (AAA e romance antigo). No entanto, a abordagem toma caminhos inversos. No romance grego, geralmente ela representa um pacto de fidelidade entre o jovem par, uma demonstração da resistência do amor diante das provações e tentações, ressaltando a virtude do domínio próprio dos heróis, sendo que a experiência sexual é predominantemente reservada para

\footnotetext{
${ }^{131}$ No entanto, é importante considerar que a nomeação do autor pode ser mais um elemento ficcional do romance, já que seus autores se fazem conhecer apenas por seus nomes, declinados na própria obra, não havendo nenhuma outra informação sobre eles. Além disso, há toda uma série de narrativas marginais, à maneira do romance, de autoria indeterminada ou cuja atribuição é contestada. É o caso do Romance de Esopo, anônimo, ou do Asno e do Romance de Alexandre, que são atribuídos a Peseudo-Luciano e PseudoCalístenes respectivamente.

132 Nogueira (2016, p. 17) percebe aí um caráter ambíguo nos AAA, já que se trata "de textos de gente comum, mas, ao mesmo tempo, em sintonia com tendências inovadoras da literatura do oriente do Império, a saber, a segunda sofística e sua forma de narrativa: a novela grega".
} 
o casamento. Nos AAA, a castidade também se apresenta como indicador da tenacidade do amor e da fidelidade dos heróis, mas, nesse caso, em relação à fé. Além disso, nessas obras a privação do sexo é para toda a existência, sendo a castidade um requisito fundamental para a vida cristã e constituindo também componente estruturante do esquema típico dessas obras. Quanto a isso, Pervo observa, como já vimos antes, que a "aversão à relação sexual, mesmo de um casamento legal" é o gatilho que dispara a perseguição movida contra os apóstolos por noivos e maridos ofendidos. No entanto, essa perseguição "serve apenas para acelerar [os apóstolos] em direção a novos campos e mais conversões, até o último episódio, quando a coroa do martírio é finalmente concedida" (1996, p. 693).

Outra característica romanesca que pode ter sido absorvida pelos AAA é a reelaboração de outros gêneros, estabelecendo diálogo evidente com os textos dos quais deriva. John Morgan (2008, p. 218) interpreta que a relação textual tem duas acepções: a alusão - de competência do autor, deliberada, ornamental ou estruturante; e a intertextualidade, "uma propriedade dos textos quando acionada por seus leitores, não necessariamente exercida de forma consciente por seus autores; pode dizer respeito a intertexto específico, mas igualmente a uma práxis literária mais geral". Sendo em muitos aspectos semelhantes uns aos outros, a relação entre os romances é óbvia, não sendo custoso também citar as relações deste com os gêneros clássicos, as quais são propositadamente buscadas como uma tentativa de legitimação.

Quanto à relação entre as narrativas apócrifas que estamos estudando, Pervo observa que, da mesma forma que há diferenças assinaladas entre os romances gregos, os AAA também apresentam entre si distinções bastante acentuadas "na ideologia, estilo e estrutura" (1996, p. 691). A explicação disso, pode estar no propósito de cada um deles. Para Hägg (1983, p. 162), por exemplo, “As histórias dos apóstolos, [...] ofereciam a oportunidade de diferentes movimentos difundirem suas variedades peculiares de fé". Nesse caso, Atos de Tomé divulgariam o gnosticismo, enquanto APT defenderia a vida ascética.

Quanto à relação com textos cristãos (orais ou escritos) já reconhecidos, é evidente a ligação dos AAA com estes. São personagens, lugares, expressões, fatos que apresentam uma clara intertextualidade com materiais familiares aos leitores cristãos, o que favorece grandemente a validação das obras e, consequentemente, sua aceitação. Não é difícil para a audiência cristã reconhecer nos AAA traços dos evangelhos, das epístolas e do livro de Atos. Com este último, os AAA compartilham narrativas de viagens, perseguições e 
julgamentos, prédicas e conversões. No entanto, apesar desses pontos em comum, as diferenças não passam despercebidas. Atos dos apóstolos, o livro do Novo Testamento que narra a expansão do cristianismo através dos labores dos apóstolos, em especial de Paulo, tem uma apresentação claramente vinculada à historiografia. Vielhauer afirma: “O autor do livro de atos canônico quer ser historiador, quer escrever história e dispõe de vários recursos técnicos e literários da historiografia. ${ }^{133}[$ [...] Como historiografia seu livro deve ser entendido em termos absolutos em seu sentido; mesmo que apresente uma história religiosa" (2005, p. 428, 429). Entretanto, quando expostos à comparação, podemos ver que os AAA subvertem as semelhanças que compartilha com esta obra, como bem aponta Ipiranga Junior (2013, p. 14 - grifo nosso):

\begin{abstract}
"Há toda uma polêmica para classificar os Atos canônicos segundo um determinado gênero; a despeito de declaração que os assimilam a ficções, são qualificados geralmente segundo a rubrica de monografia histórica ${ }^{134}$, que apresentaria uma série de similaridades quanto aos procedimentos técnicos e estilísticos com a historiografia helenística. Por seu turno, os Atos Apócrifos tendem a mimetizar esse tipo de escrita historiográfica cristã, mas não apresentam um interesse de manter qualquer fidelidade histórica dos fatos, deles se utilizando ou mesmo os inventando segundo as necessidades da narrativa".
\end{abstract}

Considerando, então, que os Atos canônicos se filiam ao discurso verdadeiro podemos afirmar que os Atos dos apóstolos estão para a historiografia ${ }^{135}$, assim como os AAA estão para o romance grego, pela narrativa descomprometida com a exatidão e a veracidade dos fatos, guardando a ressalva importante de que os AAA não se pretendem

\footnotetext{
133 Vielhaer (2005, p. 429) descreve as habilidades literárias do autor de Atos: "Ele sabe mostrar nexos, interpretar o sentido dos acontecimentos (discursos), sabe alternar apanhados resumidos com extensas descrições, acentuar e desenhar com poucos traços quadros impressionantes ( $\mathrm{cf}$ a descrição de Atenas em 17.16ss.)".

${ }^{134}$ Para Vielhauer (2005, p. 428, 429), o que difere Atos dos Apóstolos "de antigas historiografias, também da 'monografia histórica' [...] é a falta do interesse cronológico e a finalidade didática do livro".

${ }^{135}$ A preocupação do autor de Atos dos apóstolos em apresentar dados geográficos e históricos confiáveis foi confirmada por W. M. Ramsay, renomado arqueólogo e pesquisador que resolveu provar os pressupostos de Baur, um dos mais notáveis críticos da obra e que questionava a historicidade dos Atos Lucanos. Após viajar pela Ásia Menor, comparando suas descobertas arqueológicas, com documentos históricos e a geografia da região, com as informações de Lucas, Ramsay surpreendentemente concluiu que existem razões para colocar o autor de Atos entre os historiadores de primeira categoria" e que o livro de Atos era "uma autoridade em topografia, antiguidade e sociedade da Ásia Menor" (1898, p. 4 e 8). Para uma rápida análise literária de Atos dos Apóstolos, cf. BERGER, 1984, 324. Para uma opinião divergente quanto à autoria dos Atos Lucanos, cf. VIELHAUER, 2005, p. 420 et seq.
} 
obras de ficção, embora utilizem procedimentos desta. ${ }^{136} \mathrm{E}$ nesse jogo de distanciamento e aproximação é possível concluir que os AAA, embora guardando as já citadas semelhanças com os romances antigos, também mantêm diferenças consideráveis destes, o mesmo acontecendo em relação aos Atos Lucanos ${ }^{137}$, o que os coloca como um grupo à parte. Nesse sentido, por assimilar e transformar características de outros gêneros, utilizando-as como a organização do texto a requer, podemos ver aí também uma aproximação com o próprio romance antigo.

Tendo em vista tudo que foi dito, não é difícil perceber que o estudo comparado desses conjuntos de obras é uma tarefa, no mínimo, desafiadora. Não por acaso, Tim Whitmarsh (2008, p. 13) observa que "a relação entre cristianismo e o romance é complexa". ${ }^{138}$ Quem influenciou quem? Ao que parece, é bastante improvável que os AAA tenham exercido alguma impressão sobre os romances gregos, sendo mais provável o sentido oposto: os textos cristãos é que teriam sido influenciados por estes, como muitos estudiosos defendem e fica claro na afirmação de Pervo (1996, p. 694): "Para os Atos Apócrifos, os romances de amor eram, em algum grau, competidores dignos de emulação". ${ }^{139}$ Por sua vez, Vielhauer (2005, p. 741) assevera: "Sem dúvida, os Atos dos Apóstolos apócrifos têm seu lugar no contexto do romance antigo". ${ }^{40}$ E, para Bremmer (2001, p. 165), “a conclusão é inevitável: os autores de $A J$ e de $A P$, no mínimo, leram os romances contemporâneos e extraíram deles parte de sua inspiração".

Contudo, nem todos fazem coro nessa questão. Há vozes discordantes. Piñero e Del Cerro, segundo Sánchez (2013, p. 41), “questionam, precisamente, a dependência destas obras com relação aos modelos literários greco-romanos da época e propõem os Atos Lucanos como o modelo sobre o qual se baseiam as narrações apócrifas dos

\footnotetext{
${ }^{136}$ O próprio Ramsay, analisando $A P T$, consegue identificar, entre vários dados plausíveis, um bom número de anacronismos e adaptações que denunciam a presença da ficção na obra. Um exemplo: "Primeiro, Demas e Hermógenes aconselham que Tamiris acuse Paulo de ser um cristão, como se isto se provasse fatal para ele. Tal detalhe não poderia se originar até muito mais tarde que 50 d.C, pois a acusação era impossível naquele período" (1893, p. 392).

137 "O material narrativo dos Atos [apócrifos] tem muito pouco a ver com os Atos dos Apóstolos de Lucas em seus elementos principais e secundários; mas tem numerosas paralelas na literatura romanesca da antiguidade' e também tem parentesco com muitos elementos de lendas e contos" (VIELHAUER, 2005, p. 739).

${ }^{138}$ Romance entendido como todas as "narrativas ficcionais em prosa", de amor ou não, que fazem parte do estudo do romance antigo.

${ }^{139}$ Essa posição é adotada por uma grande parte dos estudiosos. Cf. Whitmarsh, 2008, p. 83; Holzberg, 2003, p. 28; Bremmer (1996); Sánchez, 2013, p. 46; Hägg (1993); Ipiranga Jr, 2013, p. 16 et al.

${ }^{140}$ No entanto, Rosa Söder, de acordo com Vielhauer (2005, p. 721), concluiu que os AAA “"não seriam verdadeiros romances' e 'também quanto à forma não' seriam 'um gênero uniforme'; seriam 'narrativas populares, destinadas ao povo, não tanto às pessoas cultas, como os romances"”.
} 
apóstolos". Embora o argumento dos autores espanhóis seja extremamente plausível, não vejo como deixar de levar em conta a presença nos AAA de vários elementos característicos do romance grego, como vimos acima. Uma solução para o dilema seria admitir que os AAA não se pretendiam obras de ficção, como os romances, mas usavam procedimentos destes, um dos quais seria a apropriação de marcas peculiares de vários gêneros, deslocando seus sentidos e dando-lhes uma forma própria. ${ }^{141}$ Assim, além da influência dos romances, não se desconsidera a presença relevante de componentes da historiografia, da biografia cristã, dos evangelhos, dos Atos Lucanos e das epístolas dos apóstolos, dos quais o sentido inicial de suas marcas é deslocado em benefício da organização da própria narrativa. Uma demonstração disso em APT, por exemplo, são os macarismos (bem-aventuranças), muito familiares aos seguidores de Jesus por causa do famoso Sermão do Monte. No discurso de Paulo, em APT, eles foram modificados para enfatizar a castidade e o domínio próprio, temas recorrentes dos AAA. Já o vínculo com o romance pode ser bem exemplificado pelo deslocamento do objeto do páthos erotikón ${ }^{142}$, que passa a se referir tanto ao sofrimento do martírio, decorrente de sua fé apaixonada, como ao tema da castidade, o que, segundo Ipiranga Junior (2013, p. 80), altera o caráter da narrativa a ponto de impossibilitar-lhe um lugar no grupo de romances gregos.

O diálogo dos AAA com os romances parece indiscutível e é observável na forma (textos narrativos com forte presença de ficção), na recorrência dos temas (perigos, viagens pelo império, piedade, castidade, páthos amoroso, eventos maravilhosos, entre outros) e nas alusões e inserções de trechos dos Evangelhos e Atos canônicos, numa clara busca de legitimação dentro da tradição literária cristã. Para Vielhauer $(2005,744)$, os AAA “documentam a recepção de gêneros da literatura mundana [...] no cristianismo". E até Häag (1983, p. 161), que desaconselha tentar encontrar o gênero do qual deriva os AAA, entende que a gênese e procedimentos dos AAA emulam às dos romances antigos:

\footnotetext{
"A história do nascimento do romance se repetiu novamente. Uma nova situação histórica, com novas demandas, deu origem a uma nova forma literária,
}

\footnotetext{
${ }^{141} \mathrm{O}$ dilema da relação entre os AAA e o romance antigo é bem expressado por Nogueira (2016, p. 17): “A forma como os AAA estão relacionados com a novela grega é uma questão central e controversa na pesquisa. Eles compartilham temas com essa literatura, no entanto invertem e subvertem suas soluções narrativas."

142 Ipiranga Junior apresenta a concepção deste páthos erotikón como um estado em que os personagens são atingidos por uma "emoção ou afecção [...] de forma intensa e avassaladora. Esta afecção é expressa como páthos, sofrimento ou emoção lancinante, mas também no sentido mais específico de paixão amorosa, que incluía todos os sentidos anteriores" (2013, p. 66).
} 
a qual livremente tomou empréstimos de predecessores e contemporâneos. $\mathrm{O}$ romance foi talvez a principal fonte de empréstimos, e não há dúvida de que sua popularidade foi deliberadamente usada para propagar a nova fé”.

Bremmer, como já visto acima, sustenta a mesma opinião. No entanto, logo na sequência, o mesmo estudioso chama a atenção para outras diferenças importantes entre os dois conjuntos de obras: o martírio de um apóstolo como centro dos AAA, o final feliz configurando-se na castidade (e não no casamento) e a presença corriqueira de romanos no mundo ficcional dos AAA, elemento marcadamente ausente dos romances de amor ideal gregos. ${ }^{143}$ Ou seja, por mais que apresentem semelhanças importantes, os grupos não se confundem.

\section{Os Atos de Paulo e Tecla e o romance antigo}

Tendo em vista as diferenças e semelhanças entre os AAA e os romances gregos, podemos nos aproximar agora de Atos de Paulo e Tecla, essa narrativa curta, porém de muito sucesso, na qual encontram-se vários elementos estudados acima e que serão discutidos na sequência.

Pedro Ipiranga Junior analisou o papel marcante do páthos erotikón sobre a protagonista desta obra, colocando-a em paralelo com Calírroe e Asenath, respectivamente heroínas de um romance grego, Quéreas e Calírroe, e de um texto supostamente judaico, José e Asenath. Nós nos deteremos aqui nas considerações acerca do romance grego e sua comparação com APT, dado que o de José e Asenath não se encaixa no âmbito deste estudo.

Calírroe, a caminho de uma festa no templo de Afrodite (impelida por Eros), casualmente encontra Quéreas, em uma curva do caminho. Ambos são muito jovens e lindos. E a visão recíproca não passa sem consequências. "Assim o deus traçou essa rota, para que se avistassem. A paixão amorosa foi logo correspondida, pois a beleza vai de par com a nobreza" (CÁRITON I.1). Como que golpeado, Quéreas volta para casa arrastando-se, enquanto Calírroe suplica a Afrodite que lhe dê o moço como marido. A afecção pelo páthos se mostra tão avassaladora que, temendo ser entregue como esposa a outro homem, a moça quase morre. Analisando o episódio, Ipiranga Jr. argumenta:

${ }^{143}$ Cf. GOLDHILL, 2008, p. 196. 
"Nessa cena prototípica do romance amoroso, o páthos erotikón é transmitido pela visão. Atinge aqui uma espécie de clímax essa atividade mimética gráfica, fazendo do elemento visual o grande agenciador do páthos e, por conseguinte, do desenrolar da narrativa" (2013, p. 75).

A heroína do romance cristão, por sua vez, experimenta uma afecção semelhante em seus efeitos, mas distinta em sua fonte. Sentada à janela de sua casa, Tecla ouve, paralisada, a pregação de Paulo na casa vizinha. Sua mãe, aturdida com o comportamento anormal da filha, chama o noivo da moça e o informa do estado alarmante de Tecla, tomada pelo páthos. Devido a essa paralisia total, que a torna alheia a todos, Ipiranga Jr. considera que “o páthos sentido por Tecla é, a princípio, da mesma ordem e, talvez, num grau ainda mais intenso que a afecção amorosa sentida pela heroína típica do romance grego antigo" (2013, p. 79). No entanto, o pesquisador conclui que essa seria uma "afecção própria do recém-convertido, aqui retratada como alheamento e êxtase, mas podendo vir a ter uma conotação de penitência, sofrimento e arrependimento" (2013, p. 82). ${ }^{144}$ Desde que não há registro no Novo Testamento de cristãos experimentando uma afecção paralisante por ocasião de sua conversão, vemos aqui, que o autor se apropriou deste elemento tão próprio do romance grego e o colocou a serviço de sua narrativa, dando-lhe um caráter romanesco.

Da mesma forma que as narrativas romanescas estão permeadas de alusões aos gêneros literários clássicos, na busca de uma legitimação, $A P T$ não deixa de fazê-lo. No início da narrativa, Paulo está chegando a Icônio, em fuga de Antioquia, acompanhado de Demas e Hermógenes e é recebido por Onesíforo, que fora avisado por Tito da chegada do apóstolo. Todos esses nomes e fatos eram familiares ao leitor que tinha contato com a tradição oral ou escrita do universo cristão, o que favorecia a aceitação do texto. No entanto, em $A P T$ eles são ajustados em uma nova narrativa, com eliminação e adição de elementos. Se essa narrativa se reporta à primeira viagem de Paulo, descrita em Atos 13:50, 51 e 14:1-6, o companheiro de Paulo é Barnabé e a perseguição em Icônio, bem como em Antioquia, não é instigada por noivos e maridos furiosos, mas pelos judeus e pagãos que não creram na mensagem de Paulo acerca de Jesus. Se a cena se refere à

\footnotetext{
${ }^{144}$ Häag (1983, p. 160) já entende que as reações de Tecla enquanto ouve o apóstolo (não comer, nem beber, alarmando a família com a alheação de seu comportamento) lembram manifestações físicas do despertar para o amor e faz parte do elemento erótico presente no texto. Para ele, os olhares e gestos trocados por Paulo e Tecla indicam que a relação entre ambos não é exclusivamente espiritual. Uma outra possibilidade para essa relação seria pensar também no papel desempenhado por eros na filosofia platônica, em que o vínculo erótico, ainda que "platônico", entre discípulo e mestre é um poderoso estímulo para a aquisição do conhecimento. Cf. especialmente Platão, Simpósio e Fedro.
} 
segunda viagem missionária, o apóstolo está acompanhado de Silas. Tanto nesta quanto na terceira viagem, nenhuma menção a perseguições é encontrada em Atos. E em todas as três, nada é dito sobre a castidade, nem sobre Tecla ou outras mulheres convertidas ao celibato. Ao invés de Barnabé ou Silas, em APT, os companheiros de Paulo são Demas e Hermógenes, nomes de dois conhecidos desertores da fé (mencionados em 2 Timóteo 4:10 e 1:15) que fornecem dois dos vilões necessários à trama. Já a boa reputação de Onesíforo, que é mencionado em 2 Timóteo 1.16 como tendo atendido às necessidades de Paulo em Éfeso e Roma e, em 4:19, como possuindo uma família cristã, serve como uma luva na trama de $A P T$ para compor o devotado anfitrião de Paulo em Icônio. No discurso de Paulo, como já mencionamos, as bem-aventuranças, um elemento da tradição cristã facilmente reconhecível (o Sermão da Montanha), são reelaboradas para atender ao interesse doutrinário da obra, de teor aparentemente encratista. Ainda que com fins utilitários (a propagação de um posicionamento doutrinário, por exemplo), a estratégia de reelaboração da matéria dos Atos canônicos utilizada por esta obra cristã mais uma vez a aproxima dos romances gregos.

Em APT encontramos também vários dos temas habituais às narrativas romanescas. Paulo viaja em fuga para Icônio e de lá, acompanhado por Tecla, vai a Antioquia. Há cenas de julgamento e de multidões inflamadas. ${ }^{145}$ Como nas obras gregas, nos quais o amor é posto em teste para provar sua resistência, em APT as provações também surgem para Tecla, mas com o fim de provar o vigor de sua fé. Ela é entregue para ser queimada, sofre o assédio de Alexandre e é condenada ao dilaceramento pelas feras na arena. Tal qual seus pares pagãos, a heroína cristã supera as ameaças e chega invicta ao final da narrativa. Outros temas mais poderiam ser mencionados aqui. No entanto, penso que a castidade merece uma atenção maior.

Tecla escuta por três dias e três noites a pregação de Paulo "acerca do domínio

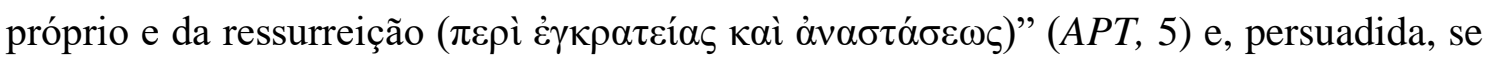
converte em uma seguidora do apóstolo, o que implica em manter-se virgem pelo resto da vida. Aqui a relação com os romances gregos se faz tanto pela semelhança quanto pelo contraste. O tema da preservação da castidade a todo custo é tão caro em APT quanto nos romances. A diferença é que nestes "a consumação do casamento é o ápice da celebração da cidade, de sua identidade e tradições" enquanto que "nos Atos de Tecla o celibato (mais precisamente a enkratéia - autocontrole) é o valor central, o distintivo da identidade

\footnotetext{
${ }^{145}$ No entanto, vale ressaltar que todos esses temas (fuga, viagem, julgamento, multidões inflamadas e outros semelhantes) estão presentes também em Atos dos apóstolos.
} 
do grupo cristão. Paulo e Tecla são, dessa forma, apresentados como amantes idealizados, mas com expectativas invertidas." (NOGUEIRA, 2016, p. 21). E, embora seja um tema valorizado no romance, sua abordagem varia de obra para obra. Calírroe casa-se no início da trama. Tida como morta, após uma agressão gerada pelo ciúme de Quéreas, acaba sendo levada por piratas para a Ásia, onde, por sua beleza, atrai o amor de Dionísio, o principal da cidade, com quem acaba se casando. Em Dáfnis e Cloé, a virgindade da moça até o casamento só é assegurada porque tanto ela como Dafnis, desconhecem os mecanismos da atividade sexual. Em APT a virgindade é guardada como garantia da vida eterna, e a felicidade consiste em conseguir mantê-la até o fim da existência; mesmo aos casados, a abstinência sexual é requerida. ${ }^{146}$ Essa postura radical chamou a atenção de estudiosos, já que, pelo menos aparentemente, contrasta também com o texto canônico ${ }^{147}$. Como comenta Perkins (2014, p. 102), "Paulo preferia o celibato, mas aceitava o casamento. No segundo século alguns paulinistas favoreciam o celibato a ponto de requerê-lo". Mais uma vez se vê aqui uma característica temática do romance grego, reformulada no texto cristão.

Nos romances gregos, os incidentes complicados do enredo são resolvidos através de uma estratégia simples, mas eficiente para seu propósito: a presença da Týkhe. ${ }^{148}$ Causadora de eventos inesperados que favorecem a construção do enredo, é concebida ora como acaso, quando se trata de algo acidental, ora como Fortuna, quando ordena os fatos e os orienta para um determinado rumo. Nos textos cristãos esse elemento solucionador também aparece. No entanto, o Deus dos cristãos exerce o papel da Fortuna dos romanos, sendo também denominado Providência. Passamos agora a identificar algumas das manifestações da Providência em APT.

\footnotetext{
146 "Bem-aventurados os que, tendo mulheres, agem como se não as tivessem, porque serão herdeiros de Deus" (APT, 5).

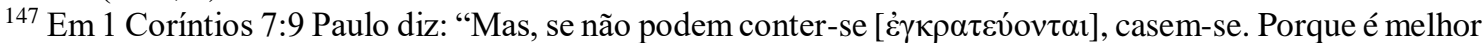
casar do que abrasar-se [ $\pi$ voṽ $\sigma \theta \alpha$ ] ]". E em 1 Timóteo 4:1-3, há a advertência contra o ensino de homens

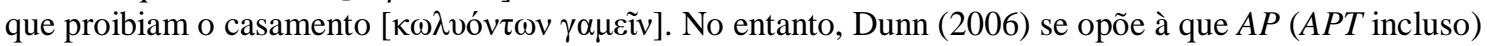
seja encratista ou proíba o casamento. Seu estudo sobre o assunto é até bastante plausível.

${ }^{148}$ Acho muito proveitoso o conceito de Políbio a respeito da Týhhe. Interessado em explicar as causas dos acontecimentos, especialmente as guerras, o historiador grego constrói uma teoria em que "o motor dos acontecimentos são os pensamentos dos indivíduos" e na qual "os discursos têm por função explicar a influência dos agentes, as ações e as decisões da vida pública" (SEBASTIANI, 2012, p. 56,7). No entanto, apesar do apuro de sua teoria, "Políbio identifica uma potência que se interpõe entre a causa e o efeito, a baralhar as previsões mais rigorosas e a esquivar-se à dialética do historiador: a fortuna ou o acaso (týche, autómatum)". Esse elemento "é definido por Políbio sob duas acepções: a) uma potência superior, que se sobrepõe às causas sem excluí-las, e ordena os acontecimentos orientando-os para um fim determinado [...], de matiz divino ou sobrenatural, melhor vertida por fortuna. b) a ocorrência acidental, como irrupção súbita de nevascas, secas ou pestes, que escapa à lógica e à previsão, melhor vertida como acaso" (SEBASTIANI, 2012, p. 60).
} 
A primeira manifestação do que os gregos chamariam de Týkhe na obra pode ser atribuída à coincidência de Paulo pregar na casa vizinha à de Tecla, de onde, a partir de uma janela, ela tem acesso ao discurso do apóstolo e é acometida de um estado de alheamento que sua mãe considera um páthos amoroso. Se levarmos em conta que a acepção divina, aqui referente a Deus, sempre interfere positivamente para com o fiel, podemos imaginar que, do ponto de vista do narrador cristão, sua conversão tenha sido produto da intervenção divina, a qual, na economia da narrativa, está presente também nos eventos surpreendentes (paradóxa) tal como a chuva torrencial que salva Tecla da morte na fogueira e, ao mesmo tempo, se converte em pena para os algozes da moça.

É possível que essa mesma interferência divina, agora na forma de um acontecimento fortuito, seja a causa do reencontro entre Paulo e Tecla, o que a leva a viajar para Antioquia, onde o encontro acidental com Alexandre altera novamente o rumo dos fatos, levando-a a um novo martírio, dessa vez uma luta contra feras. Apesar do vigoroso protesto da rainha Trifena, sua protetora, e de um grupo de mulheres, a virgem é levada, nua, ao espaço de sua execução. No entanto, mais uma vez sua sorte é alterada por manifestações divinas em seu favor, impedindo, de uma forma ou de outra, todos os animais de feri-la e fornecendo até mesmo o improvisado tanque batismal, onde ela realiza em si mesma o rito sagrado do batismo. Percebendo a inutilidade de continuar tentando martirizá-la, o governador a liberta e Tecla, após encontrar Paulo e receber dele uma espécie de autorização para pregar, termina sua vida pregando e curando, salva graças à intervenção divina, o que nos romances seria atribuído à Týkhe.

É certo que $A P T$ apresenta diferenças marcantes com o romance. Começando pela língua (koiné), podemos citar, entre outras, a presença de personagens romanos e do universo cristão, a aparência algo grotesca de Paulo (além da evidente diferença de idade entre os dois protagonistas), a renúncia total ao sexo (preservação da castidade por toda vida e não só até o casamento), a morte em idade avançada da protagonista, ${ }^{149}$ a separação permanente do par central, a provação da fé, mais que do amor, e a completa ausência de Eros como fator de aproximação do par protagonista. ${ }^{150}$ No entanto, as semelhanças e paralelos entre $A P T$ e o romance de amor ideal são por demais abundantes e não podem ser desconsideradas. Tecla é jovem, bela e pertence à elite de Icônio. Sua formosura atrai Alexandre e é causa de provação. Ela prefere sofrer o martírio a renunciar a sua fé ou perder a castidade. O estado de alheamento que a acomete é, sem dúvida, muito

\footnotetext{
${ }^{149}$ Fato que não acontece no romance, o final feliz fixando os protagonistas em uma eterna juventude. ${ }^{150}$ Eyl (2012, p. 15) considera a ausência de Eros como a marca distintiva entre APT e os romances.
} 
semelhante ao páthos erothikon experimentado pelas heroínas do romance de amor. Há viagens, julgamentos, multidões, provações inesperadas e vilões: os temas e cenas típicos das narrativas pagãs permeiam toda a obra. As intervenções divinas e o acaso são agentes condutores da trama, determinando as mudanças na ação, da mesma forma que a Týkhe o faz nos romances. As alusões e referências à tradição literária cristã, já conhecidas do leitor, são reelaboradas de acordo com a necessidade da narrativa e os propósitos da obra, uma estratégia romanesca muito típica.

Então, seria possível definir APT como um romance? Sendo parte de um dos AAA, chamados por Pervo (1996, p. 709) de "Christian novels" e de "Christian fictions", $A P T$ não deixa de se identificar com os romances, como vimos acima. ${ }^{151}$ Mas as diferenças também são inegáveis. E os antigos tinham capacidade para perceber isso, o que é bem ilustrado pelo próprio Pervo ao sugerir que um hipotético "bibliotecário do ano 175, diante de Metamorfoses, atribuído a Lúcio de Patras, Leucipe, Um conto efesíaco e os Atos de Paulo, sem hesitação colocaria os três primeiros em uma prateleira, por assim dizer, e o último em outro lugar" (1996, p. 694). Ou seja, embora apresentem afinidades, a distinção entre os dois grupos é clara o suficiente para não causar confusão. ${ }^{152}$ E o estudo de ambos amplia consideravelmente a compreensão do conjunto literário do Período Imperial. Eis por que $A P T$ pode deixar o espaço restrito dos cursos de teologia, nos quais ajuda a entender vários aspectos do cristianismo primitivo, e ser introduzido, sem embaraço algum, no corpus de estudo do romance antigo, na área de clássicos de uma instituição laica como a Universidade de São Paulo.

\footnotetext{
${ }^{151}$ Pervo $(1996$, p. 692, 693) afirma que, assim como os leitores dos romances eram conscientes de que estes não se constituíam em relatos reais, o mesmo poderia acontecer com os leitores e ouvintes dos AAA. Possivelmente, eles reconheciam nessas obras, o caráter ficcional, posto que edificante. Contudo, entendo que essa afirmação pode não representar a visão de todos os leitores dos AAA. Pelo menos para alguns grupos que se denominavam cristãos, $A P T$, por exemplo, pode ter sido algo mais que isso, a julgar por aqueles que se serviam dele para defender a autorização de mulheres batizarem e pregarem.

${ }^{152}$ Johnson observa apropriadamente que "enquanto estão sendo escritos, disseminados, traduzidos e culturalmente absorvidos em um contexto romano, os apócrifos cristãos representam mundos imaginativos que fazem sentido apenas para a mente cristã" (2017, p. 680). E Hirschberger (2012, p. 153) chama a atenção para o fato de que todos os temas dos romances são subvertidos nos AAA.
} 


\section{CONSIDERAÇÕES FINAIS}

Neste estudo procurei apresentar uma visão geral de Atos de Paulo e Tecla, fornecendo ao leitor de hoje subsídios para uma compreensão e aproveitamento dessa obra. Nosso ponto inicial foi buscar a origem da literatura cristã, para posicionar adequadamente nossa obra de estudo. Então vimos que de início a mensagem de Jesus foi transmitida basicamente de forma oral. Após sua morte, embora predominasse a transmissão oral, a adesão ao registro escrito possibilitou o surgimento dos textos que hoje formam o cânon neotestamentário, além de uma variedade de outras publicações e gêneros, tais como cartas, tratados, atas e narrativas com temas cristãos, sendo que as últimas apresentam muitos pontos de contato com os romances de amor ideal, que floresciam simultaneamente. Os Atos Apócrifos dos Apóstolos se enquadram nessa literatura cristã, aparentada com os romances, cujos principais exemplares são narrativas sobre André, João, Paulo, Pedro e Tomé.

Atos de Paulo e Tecla é uma das partes que constituem Atos de Paulo, considerado o mais antigo dos AAA. Apresentamos, então, as discussões que envolvem os diversos aspectos dessa obra: datação, autoria, origem, recepção e local de composição. Assim, compreendemos que APT provavelmente foi composto na Ásia Menor, antes do ano 200 a.C., talvez por um presbítero que supostamente queria aumentar a popularidade de Paulo. A origem da história pode estar em lendas orais que foram compiladas pelo autor, que as editou de modo a encaixar o texto em um outro maior, junto a outras narrativas da vida de Paulo. A despeito de ser rejeitado como espúrio por Tertuliano, o texto gozou de popularidade suficiente para alcançar lugares como Cartago, na África, e Roma, na Europa, sendo posteriormente traduzido para diversas línguas do império.

Na sequência, nos propomos a analisar a obra literariamente, o que nos permitiu conhecer melhor as estratégias que o narrador utilizou para enfatizar seus propósitos de propagação da fé cristã, dentro de uma perspectiva que encoraja a encrateia (domínio próprio). A obra está dividida em duas partes, com enredo circular no qual a protagonista rejeita um homem da elite e em consequência, acaba por enfrentar o martírio, do qual escapa ilesa pela intervenção divina. Em ambas, o tema central é a castidade. O ritmo da narrativa começa lento e vai aumentando até atingir seu ápice, retornando depois à normalidade. Paulo é um personagem típico dos AAA, um apóstolo perseguido por maridos e noivos enfurecidos com sua pregação que exige a castidade até para os casados e que tem poderes sobrenaturais. Embora não os use em $A P T$, esses estão sugeridos na 
aparência de anjo que às vezes ele assume. Tecla é tanto uma típica heroína dos romances, quanto dos AAA, o que é natural já que algumas das características das protagonistas de ambos os grupos se sobrepõem: ela é bonita, pertence à elite da cidade, é casta, decidida e corajosa. Seu caráter é idealizado (ela não apresenta falhas), mas não é estático. Durante a narrativa, pudemos perceber que ela vai conquistando maior independência e desenvolvendo sua habilidade no falar, concluindo a obra como uma personagem bastante evoluída.

Em seguida analisamos as relações de $A P T$ com o gênero romance e percebemos uma notável aproximação em diversos pontos: a presença do páthos erotikón, as características da heroína, o tema da castidade, a estratégia de apropriação e adaptação de procedimentos de outros gêneros, o componente ficcional, entre outros. No entanto, os fins para os quais estes temas e elementos são utilizados, estabelecem diferenças suficientes para que o leitor perceba que $A P T$ não se identifica perfeitamente com o gênero romance. O texto tem outros propósitos e avança em direção a eles. No entanto, todo esse trabalho comparativo evidenciou que o estudo de ambos os grupos, AAA e romance antigo, amplia grandemente a compreensão de cada um deles, tornando a pesquisa bem mais rica e proveitosa.

Por fim, concluo o trabalho apresentando a tradução diretamente do grego, a partir do texto de Lipsius, com aparato crítico. Nas notas, procurei adicionar informações sobre o texto que o tornassem mais claro e interessante. E, no apêndice, acrescentei ainda mais detalhes, e alguns recursos visuais, os quais podem facilitar a compreensão de certos termos, conceitos e questões debatidas neste trabalho.

Não há dúvida de que há muito mais a dizer sobre este texto, mas creio que a proposta de oferecer um estudo inicial foi alcançada. Que os diversos aspectos aqui expostos possam servir de estímulo para uma pesquisa mais ampla e profunda em língua portuguesa, que ofereça ao público lusófono mais oportunidades de conhecer e compreender melhor tanto a literatura cristã primitiva, quanto o romance antigo. 


\section{ATOS DE PAULO E TECLA}

\section{Tradução}

\section{Nota à tradução}

O texto base para esta tradução é a edição corrente dos Atos de Paulo e Tecla, de R. A. Lipsius, data do século XIX (Acta apostolorum apocrypha, vol. 1. Leipzig: Mendelssohn, 1891, 235-271. Disponível em https://archive.org/stream/actaapostolorvm01tiscgoog\#page/n354/mode/2up), que já perfez mais de um século. Desde então, novos papiros e manuscritos foram incorporados à tradição do texto e têm recebido atenção de vários pesquisadores, mas ainda não se estabeleceu uma nova edição crítica. No intuito de incorporar esses progressos, realizamos, minha orientadora e eu, um cotejo do texto de Lipsius, que é o que reproduzo, com os oferecidos por de Jeremy W. Barrier em sua tese PHD, (in Barrier, J. A critical introduction and commentary of The acts of Paul and Thecla: Fort Worth, TX, 2009. Disponível em https://repository.tcu.edu/bitstream/handle/116099117/4041/barrier.pdf?sequence=1\&is Allowed=y) e J.-D. Kaestli (working in progress inédito, datado de 25/03/2016), gentilmente cedido pelo editor através da Profa Dra Luise Marion Frenkel, a quem muito agradeço. As diferenças entre os textos foram incorporadas na forma de "aparato" aposto a cada uma das sessões do texto grego e, quando incorporadas, apontadas às notas de rodapé. 


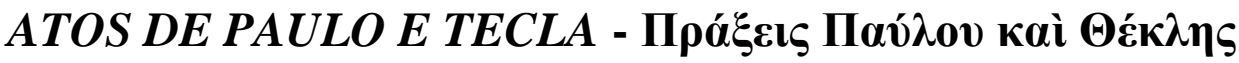

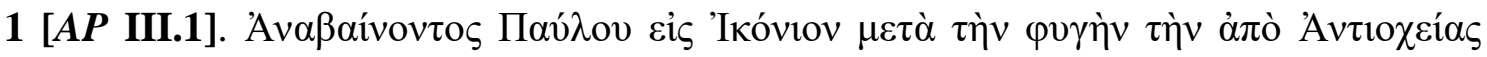

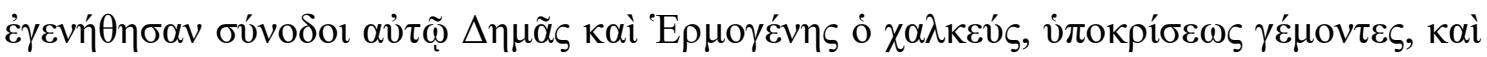

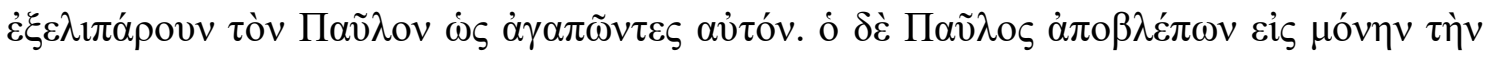

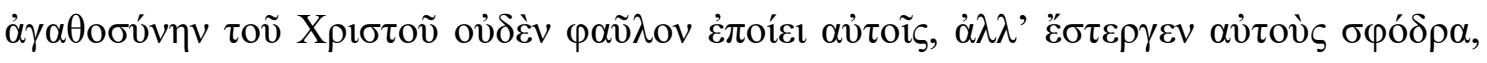

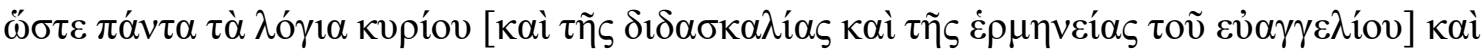

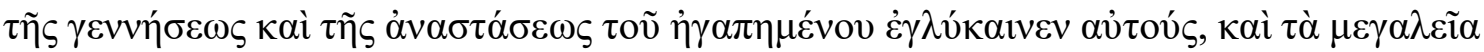

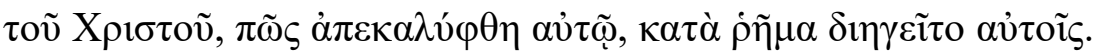

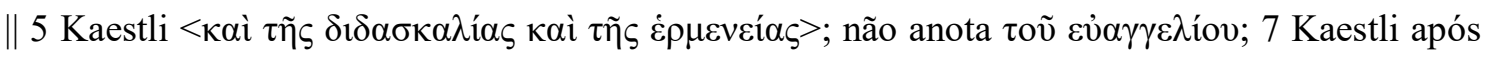
$\alpha$

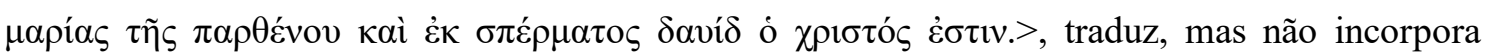
propriamente ao texto, dado que se baseia em uma versão copta.

1. Quando Paulo estava subindo ${ }^{153}$ para Icônio, depois de fugir ${ }^{154}$ de Antioquia, Demas e Hermógenes ${ }^{155}$, o ferreiro ${ }^{156}$, tornaram-se seus companheiros de viagem, os quais, cheios de falsidade, adulavam Paulo como se o amassem. Porém, Paulo, tendo em vista apenas a bondade de Cristo nada de mau fazia a eles, mas os estimava intensamente, de modo que todos os ensinamentos do Senhor, [e as doutrinas e as interpretações do evangelho] e o nascimento e a ressurreição do amado tornava doces para eles. E as grandezas de Cristo, como foram reveladas a ele, relatava-lhes palavra por palavra. ${ }^{157}$

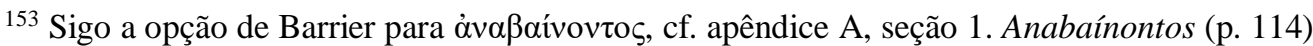

${ }^{154}$ Sobre as perseguições sofridas por Paulo em Antioquia e Icônio em $A A$, cf. apêndice A, seção 1.

155 Sobre os personagens secundários, cf. apêndice A, seção 1. Demas e Hermógenes (p. 119).

${ }^{156}$ No NT, $\chi \alpha \lambda \kappa \varepsilon v ́ \varsigma$ é uma hápax legomena (termo técnico para palavras que aparecem somente uma vez) As versões mais antigas do NT em português traduzem $\chi \alpha \lambda \kappa \varepsilon v ́ \varsigma$ ( 2 Tm 4:14 - ARC) por latoeiro, diferenciando a matéria prima de seu trabalho, que seria o bronze e não o ferro, e que é a primeira definição em LJS (p.1973): coopersmith. Mas a segunda definição é menos específica e traz worker in metal, goldsmith, worker in iron, blacksmith. Os dicionários consultados em português (DGP e LNTGP) apresentam essa acepção genérica: forjador, ferreiro, metalúrgico. As versões mais modernas do NT, como a NVI, traduzem por ferreiro.

${ }^{157}$ Nas edições de Kaestli e Barrier está acrescida a seguinte linha: "E que o Cristo nascera de Maria e da semente de Davi (também narrou)".
} 


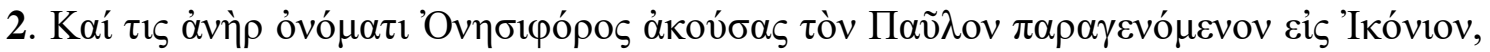

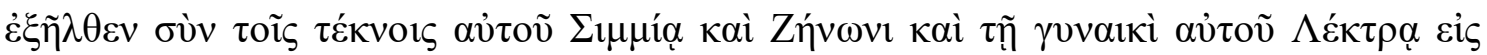

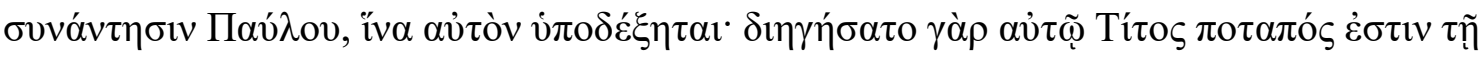

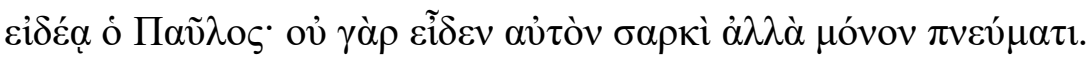

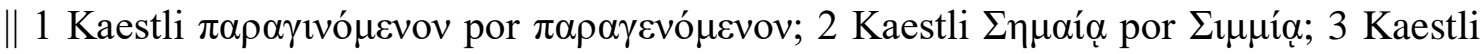

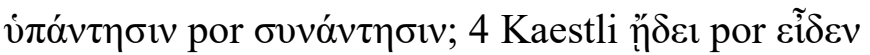

2. E certo homem chamado Onesíforo tendo ouvido de que Paulo estava a caminho de Icônio, partiu com seus filhos, Símias e Zenão ${ }^{158}$, e sua esposa, Lectra, ao encontro de Paulo, a fim de acolhê-lo. ${ }^{159}$ Tito $^{160}$ lhe havia relatado como era a aparência ${ }^{161}$ de Paulo, pois ele não o conhecia em pessoa, mas apenas no espírito. ${ }^{162}$

158 Pervo (2014, p. 96) sugere que os nomes dos filhos de Onesíforo estejam relacionados à tradição filosófica, com Zenão sendo o fundador do Estoa e Símias pertencendo ao círculo socrático. Na opinião de Bremmer, o autor de APT usa os nomes filosóficos dos filhos para sugerir um pai intelectual (1996, p. 37 e 38).

${ }^{159} \mathrm{Na}$ opinião de Pervo, o narrador presume que o apóstolo nunca estivera antes em Icônio, o que alinha essa visita com a primeira viagem missionária de Paulo relatada em Atos 13 e 14. Já Ramsay entende que o "revisor", como ele chama a pessoa que supostamente fez adaptações ao conto original de $A P T$, não omitiria personagens importantes das primeiras duas viagens de Paulo (Barnabé e Timóteo). Como em Atos não há nada registrado sobre as atividades de Paulo na região durante a terceira viagem, Ramsay entende que o "revisor" "aproveitou a lacuna para introduzir o conto de Tecla" (1893, p. 420).

${ }^{160}$ Para Ramsay, o revisor do texto de $A P T$ encontrou em 2 Timóteo 4:10 a informação de que Tito viajava à parte de Paulo, "o que o fez introduzir Tito como descrevendo Paulo a Onesíforo" (1893, p. 417).

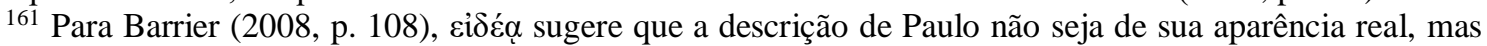
da configuração dessa aparência de uma perspectiva fisiognomística. Sobre fisiognomia, cf. nota 71, p. 29. ${ }^{162}$ Segundo Barrier, ele o conhecia em conexão com o Espírito. Tinham um vínculo espiritual, devido a compartilharem a mesma fé. 


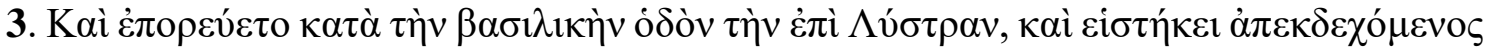

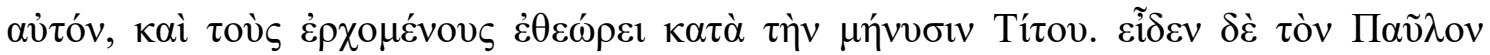

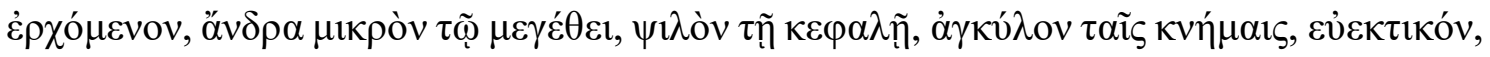

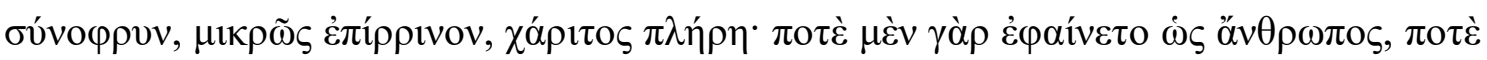

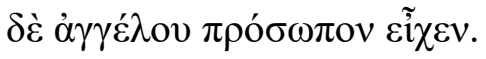

\section{|| 3 Kaestli $\mu$ «рòv por $\mu 1 \kappa \rho \tilde{\omega} \varsigma ; 4$ Kaestli $\pi \lambda \eta ́ \rho \eta \varsigma$ por $\pi \lambda \eta ́ \rho \eta$}

3. Ele tomou a Estrada Real ${ }^{163}$ que ia para Listra, e permaneceu esperando-o ansiosamente, e observava os que vinham, de acordo com a informação de Tito. ${ }^{164}$ Então, ele viu Paulo chegando: um homem de pequena estatura, calvo, de pernas curvas, sadio, monocelha, nariz um pouquinho comprido, cheio de graça ${ }^{165}$ - ora aparentava ser homem, ora tinha a face de um anjo. ${ }^{166}$

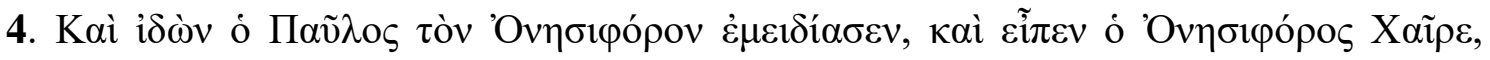

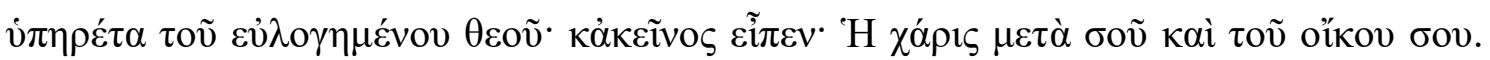

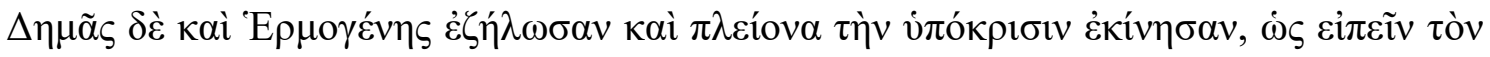

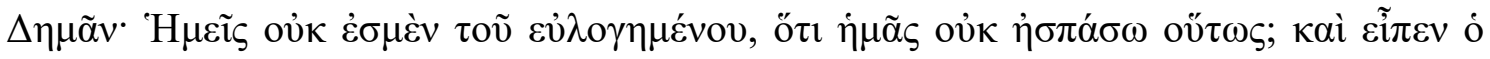

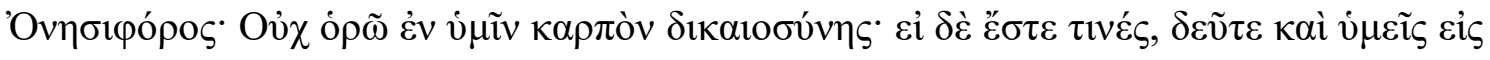

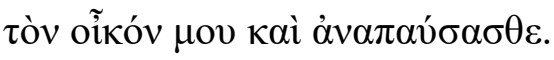

4. Quando viu Onesíforo, Paulo sorriu e, por sua vez, Onesíforo disse: “Salve, servo do Deus bendito!” E ele também falou: “A graça seja com você e com sua casa.” Mas Demas e Hermógenes sentiram inveja e, cheios de hipocrisia, ficaram agitados a ponto de Demas dizer: "Nós não somos do bendito, por isso você não nos saudou do mesmo modo?" Ao que Onesíforo respondeu: "Eu não vejo fruto de justiça em vocês. ${ }^{167}$ Mas se vocês são destes, ${ }^{168}$ venham também para minha casa e descansem".

\footnotetext{
${ }^{163}$ Cf. Apêndice 1, seção 3. Estrada Real (p. 121).

164 Sobre esta descrição, cf. p. 28 et seq, desta dissertação. Embora não se entenda que essa descrição corresponda à aparência real de Paulo, é possível que tenha influenciado a representação artística do apóstolo nos períodos posteriores. Cf. ilustração no apêndice A, seção 3. Aparência de Paulo (p. 121).

165 Expressão utilizada para descrever Jesus (João 1:14) e Estevão (Atos 6:8).

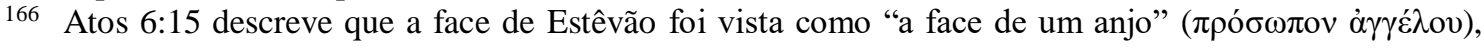
pouco antes de seu martírio.

${ }^{167}$ Edsal (2018, p. 116), vê na resposta de Onesíforo, que nota instantaneamente a ausência de "frutos de justiça" em Demas e Hermógenes, uma indicação de seu discernimento espiritual, já sugerido em 2, quando é dito que ele conhece Paulo apenas no espírito e não em pessoa.

168 "Mas se há alguns (frutos) em vocês", numa tradução mais livre (sugerida pelo professor Milton Torres).
} 


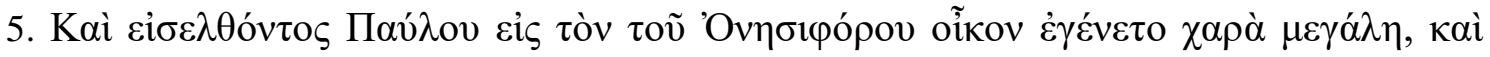

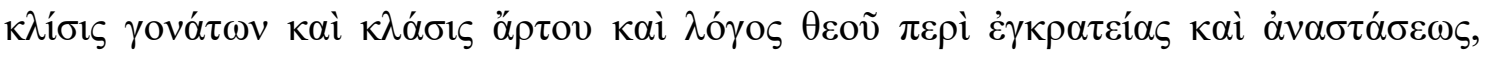

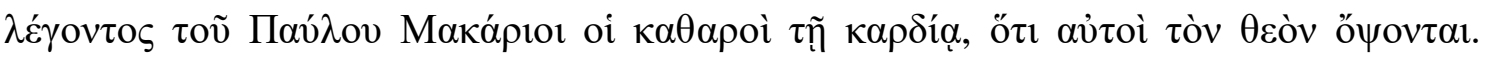

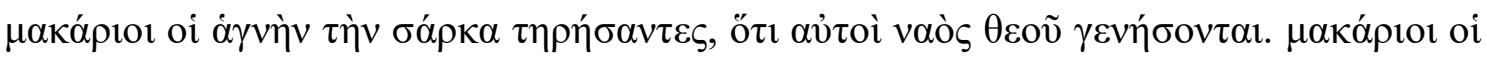

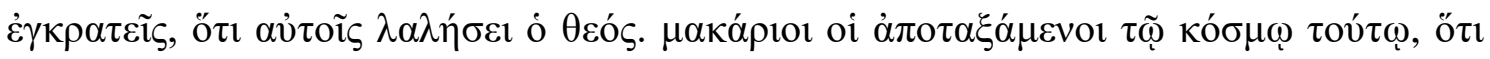

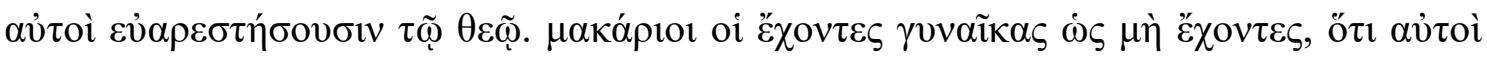

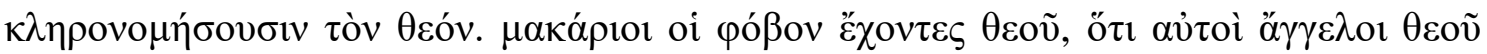

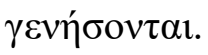

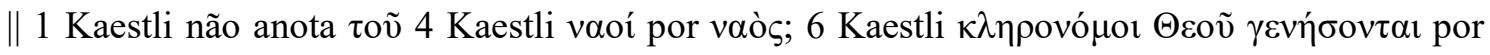

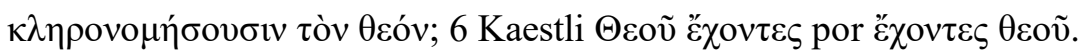

5. E quando Paulo entrou na casa ${ }^{169}$ de Onesíforo, houve grande alegria, e o dobrar dos joelhos e o partir do pão, e a palavra de Deus acerca do domínio próprio ${ }^{170}$ e da ressurreição, ${ }^{171}$ com Paulo dizendo: ${ }^{172 ~ " B e m-a v e n t u r a d o s ~ o s ~ p u r o s ~ d e ~ c o r a c ̧ a ̃ o ~ p o r q u e ~ e l e s ~}$ verão a Deus. ${ }^{173}$ Bem-aventurados os que guardam casto o corpo porque se tornarão templo de Deus. ${ }^{174}$ Bem-aventurados os que dominam a si mesmos, porque Deus conversará com eles. Bem-aventurados os que renunciaram a este mundo porque eles agradarão a Deus. Bem-aventurados os que, tendo mulheres, agem como se não as tivessem, ${ }^{175}$ porque serão herdeiros de Deus. Bem-aventurados os que têm temor de Deus, ${ }^{176}$ porque eles se tornarão anjos de Deus.

\footnotetext{
${ }^{169}$ Note-se que a casa é tida como base para a comunidade cristã e ponto de pregação.

${ }^{170}$ Enkrateia: auto-controle, moderação. A maioria dos tradutores do NT vertem-na por "domínio próprio" ou "temperança". Dessa palavra deriva o encratismo, movimento religioso do século II que pregava rigor e domínio de si, professando abstinência de carne e vinho e condenando a união sexual e o casamento. Cf. apêndice A, seção 5. Encratismo (p. 122).

${ }^{171}$ Auto-controle e ressureição constituem o núcleo dos ensinamentos de Paulo em Icônio. Sobre enkrateia, o tema mais polêmico, ver Dunn (2006).

172 Macarismo ou bem-aventurança, gênero literário bastante presente na Bíblia, caracterizado pela repetição, no início da oração do termo $\mu \alpha \kappa \alpha ́ p l o l$, isto é, bem-aventurados, felizes. Cf. Mateus 5:3-12 e apêndice A, seção 5. Macarismos (p. 122).

${ }^{173}$ Sendo que tanto a primeira bem-aventurança da seção 5 quanto a quinta da seção 6 são citações exatas de Mateus 5:7 e 8, Potter as considera como evidências de que o autor usou o texto do Novo Testamento Grego, "citando-o palavra por palavra". Em outros trechos, haveria "adaptações contextuais". Desta forma, APT contribuiu para a pesquisa de Potter em documentos apócrifos do I e II séculos (excluídos os evangelhos), o qual conclui: "o texto do Novo Testamento Grego estava relativamente bem estabelecido e fixado na época do I ao III século" (2011, p.198).

${ }^{174}$ Cf. 1 Coríntios 6:19; 2 Coríntios 6:16.

${ }^{175}$ Cf. 1 Coríntios 7:29.

${ }^{176}$ Cf. Romanos 3:18.
} 


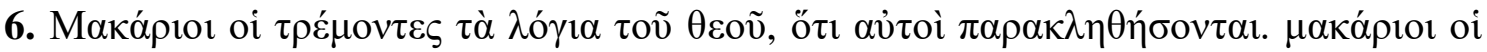

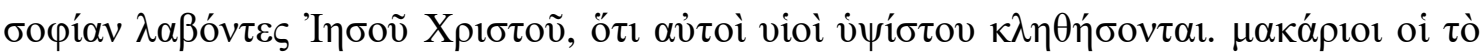

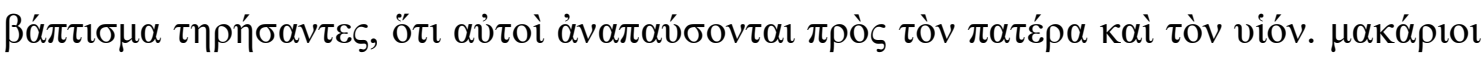

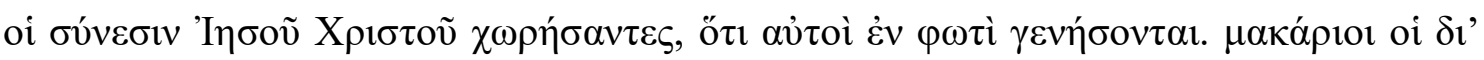

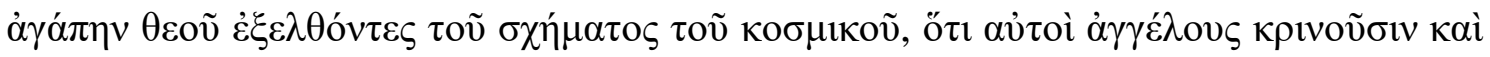

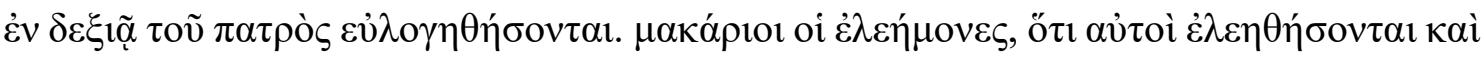

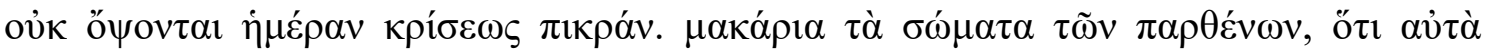

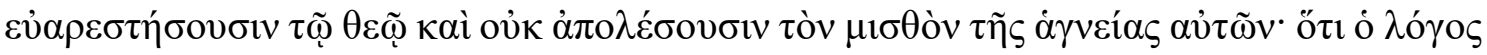

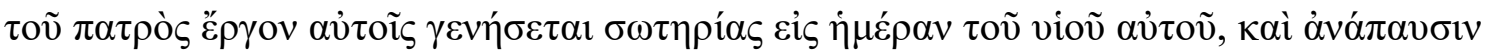
๕̌

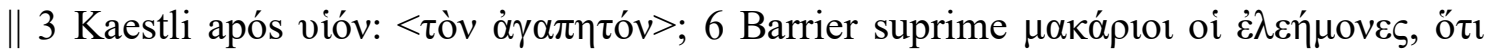

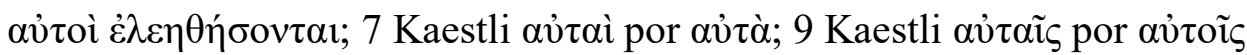

6. Bem-aventurados os que temem as palavras de Deus, porque serão consolados. Bemaventurados os que recebem a sabedoria de Jesus Cristo, porque serão chamados filhos do Altíssimo. Bem-aventurados os que guardam o batismo, porque eles descansarão junto do Pai e do Filho. ${ }^{177}$ Bem-aventurados os que abrem o coração para o conhecimento de Jesus Cristo, porque eles estarão na luz. Bem-aventurados os que, por causa do amor de Deus, abandonam o modo de vida mundano, porque eles hão de julgar os anjos ${ }^{178}$ e serão abençoados à destra de Deus. Bem-aventurados os misericordiosos porque receberão misericórdia ${ }^{179}$ e não verão o amargo dia do juízo. Bem-aventurados os corpos de quem é virgem ${ }^{180}$ porque agradarão a Deus e não perderão a recompensa da sua castidade: porque a palavra do Pai se tornará um ato de salvação para eles no dia do filho dele, e terão repouso para sempre. ${ }^{181}$

\footnotetext{
177 Kaestli acrescenta, após Filho, “amado".

178 Cf. 1 Coríntios 6:3.

179 Barrier suprime "Bem-aventurados os misericordiosos porque receberão misericórdia".

180 Pervo (2014, p. 107) chama a atenção para o conteúdo da última bem-aventurança, colocado imediatamente antes da apresentação de Tecla, uma virgem que escuta essa mensagem. As palavras parecem adiantar, veladamente, o destino de Tecla e o final da história.

${ }^{181}$ Para uma comparação com as bem-aventuranças de Mateus 5:3-12, cf. Barrier (2008, p. 133). Para comentários sobre o conteúdo das bem-aventuranças, cf. Pervo (2014, p. 100-104); Barrier (2008, p. 121133) e Sánchez (2013, p. 137).
} 


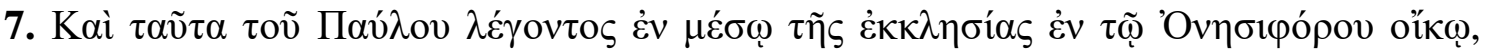

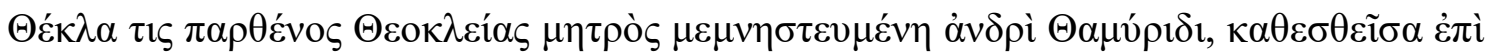

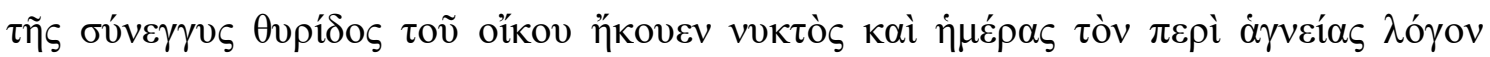

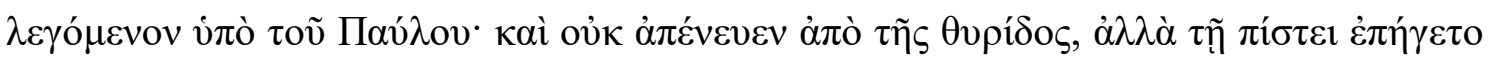

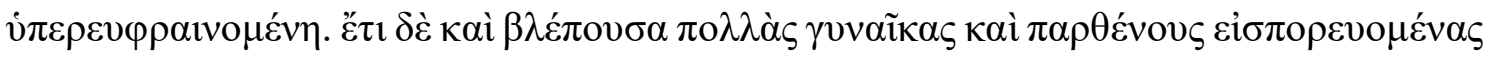

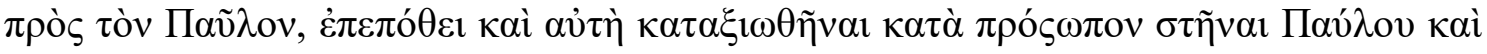

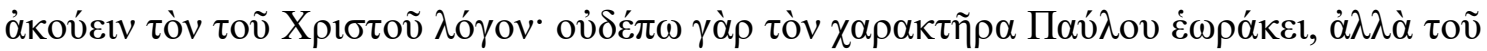

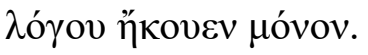

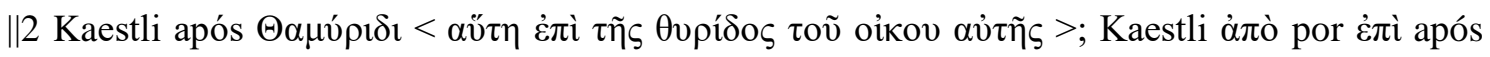

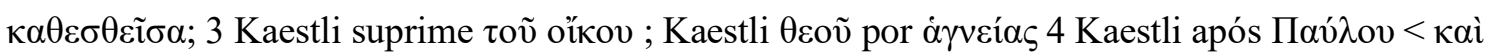

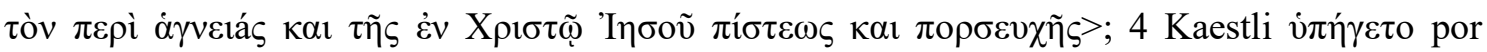
$\dot{\varepsilon} \pi \hat{\gamma} \gamma \varepsilon \tau 0$

7. Enquanto Paulo estava dizendo essas coisas no meio da reunião na casa de Onesíforo, Tecla, certa virgem, cuja mãe era Teóclia, e que estava noiva de um homem, Tamiris, estava sentada bem junto à janela da casa, e ouvia ${ }^{182}$ noite e dia o discurso proferido por Paulo sobre a castidade. E não se afastava da janela, mas era conduzida à fé, regozijandose muito. E ainda, vendo muitas mulheres e virgens entrando para ver Paulo, ansiava também ser considerada digna de estar na presença de Paulo e ouvir a palavra de Cristo, pois ainda não vira o aspecto ${ }^{183}$ de Paulo, mas só ouvia seu discurso.

\footnotetext{
${ }^{182}$ Sobre o fascínio do discurso de Paulo sobr e Tecla, cf. p. 37 et seq e p. 58 et seq.

${ }^{183}$ Barrier chama a atenção para o significado desta palavra que não é apenas o de que Tecla não havia visto Paulo ainda, mas que ela não sabia quais eram seus traços identificáveis. $\chi \alpha \rho \alpha \kappa \tau \tilde{\rho} \rho$ tem a ver com gravar, estampar uma imagem, cunhar uma figura em uma moeda. Em Electra, de Eurípides, Orestes diz

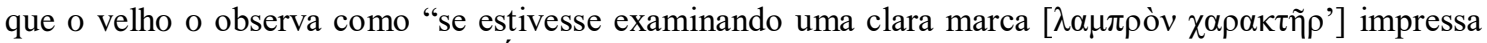
sobre uma moeda de prata" (EURÍPIDES, Electra, 559). Heródoto também a utiliza como marcas da fisionomia: "Enquanto o menino [i.e, Ciro] dizia estas coisas, parecia a Astíages que o reconhecia; a feição

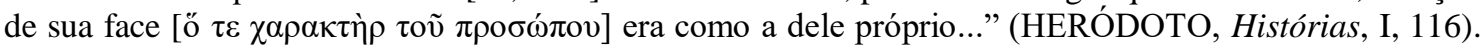
No NT aparece uma única vez, para se referir a Jesus como a expressa imagem de Deus (Hebreus 1:3). Portanto, Tecla ainda não era capaz de reconhecer as características visíveis e identificáveis (ou marcantes) de Paulo, talvez as que Tito descrevera a Onesíforo.
} 


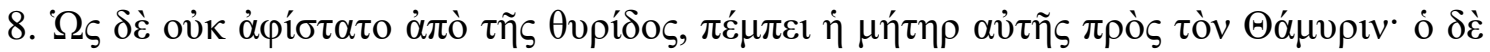

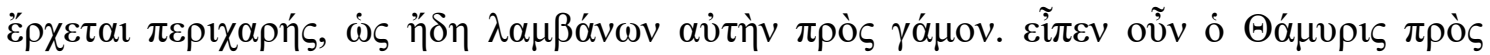

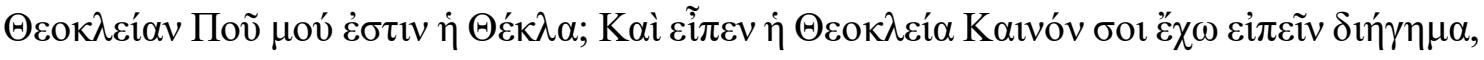

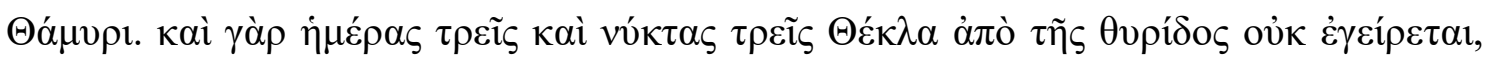

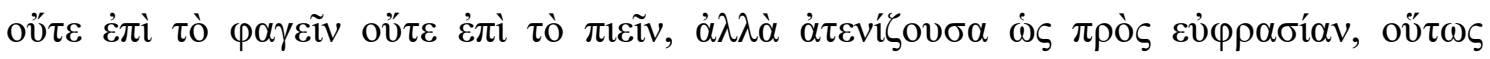

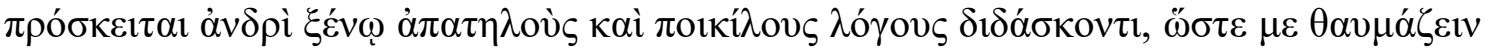

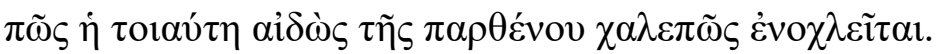

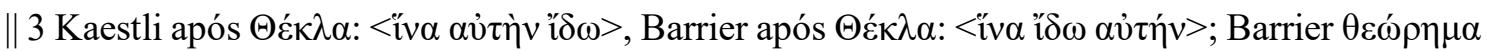

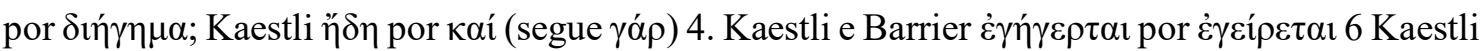

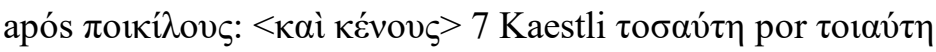

8. Como não se afastava da janela, sua mãe mandou chamar Tamiris e ele chegou muito alegre, como se já fosse recebê-la em casamento. Então Tamiris disse a Teóclia: “Onde está minha Tecla?" 184 E Teóclia disse: "Eu tenho um relato estranho para você, Tamiris. Pois há três dias e três noites que Tecla não se levanta da janela, nem para comer, nem para beber, ${ }^{185}$ mas, com o olhar absorto, como se estivesse fascinada, ${ }^{186}$ a tal ponto se liga ao homem estrangeiro que ensina palavras falsas e ardilosas ${ }^{187}$ que me admiro de como o sentimento de pudor da virgem esteja tão severamente debilitado".

\footnotetext{
${ }^{184}$ Kaestli e Barrier acrescem após Tecla: "para que eu a veja?"

185 Talvez uma alusão a Atos 9:9, que descreve o estado de profundo arrependimento que Paulo experimentou após o surpreendente encontro com Jesus: "E esteve três dias sem ver, e não comeu, nem bebeu". Chama à atenção aqui o fato de que Tecla não viu Paulo nos três dias em que esteve sem comer e beber, escutando-o.

${ }^{186}$ A descrição do estado de Tecla por Teóclia é extremamente semelhante ao das heroínas dos romances, no eclodir da paixão amorosa, estabelecendo aqui um forte ponto de contato com esse grupo de textos.

${ }^{187}$ Kaestli acrescenta "e vazias", após ardilosas.
} 


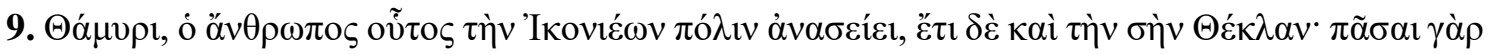

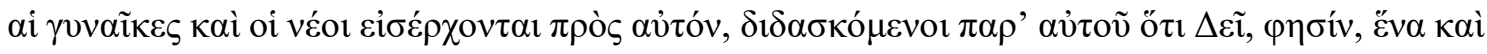

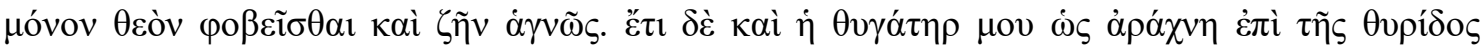

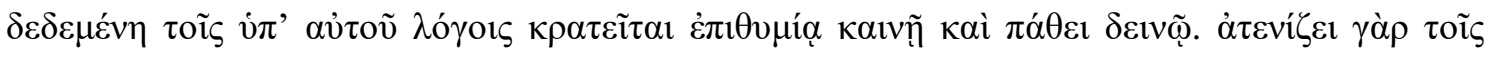

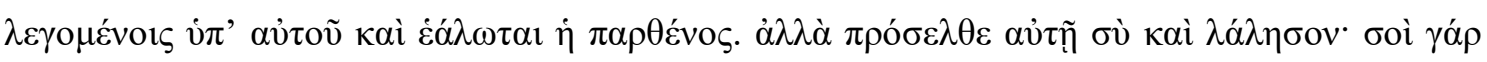
$\dot{\varepsilon} \sigma \tau \imath v \dot{\eta} \rho \mu о \sigma \mu \varepsilon ́ v \eta$

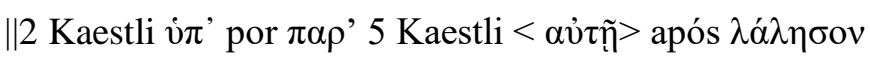

9. Tamiris, esse homem está alvoroçando a cidade de Icônio, e até mesmo a sua Tecla, pois todas as mulheres e os jovens vão até ele, sendo ensinados por ele que, como ele diz: "É necessário temer a um e único deus e viver de modo casto". E até mesmo a minha filha, como uma aranha na janela, está atada pelos discursos dele, dominada por um estranho desejo e uma paixão terrível. ${ }^{188}$ Pois a virgem está absorta pelas coisas ditas por ele e está cativada. Mas aproxime-se e converse com ela, pois é sua noiva.”

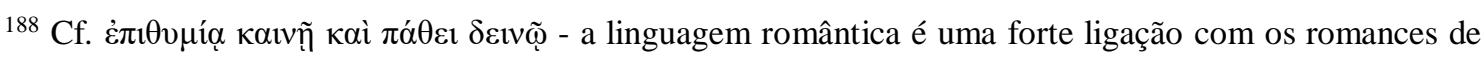
amor. O vocabulário amoroso voltará a aparecer em 18 e 19. 


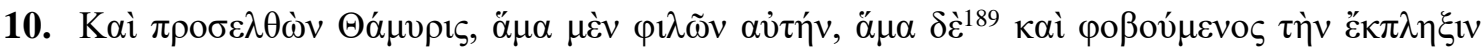

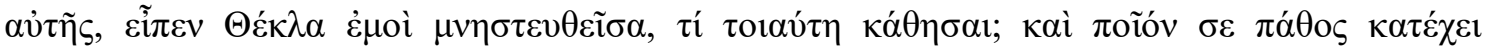

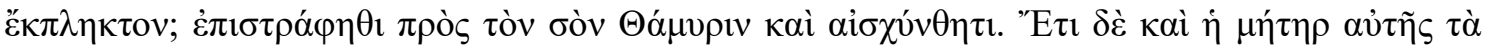

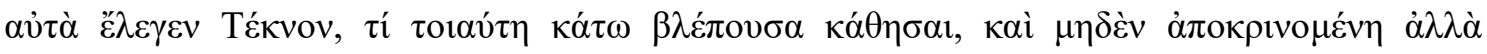

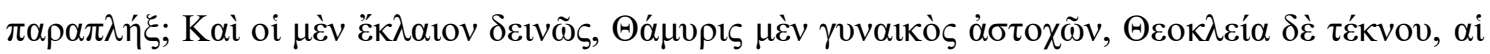

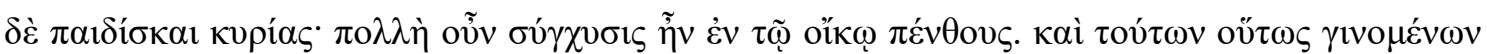

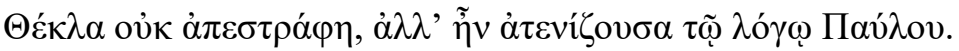

|| 1 Kaestli < $\dot{o}>$ depois de $\pi \rho \circ \sigma \varepsilon \lambda \theta \grave{\omega} v ; 2$ Kaestli $\mu \varepsilon \mu v \eta \sigma \tau \varepsilon v \mu \varepsilon ́ v \eta$ por $\mu \nu \eta \sigma \tau \varepsilon v \theta \varepsilon \tilde{\tau} \sigma \alpha ; 4$ Kaestli

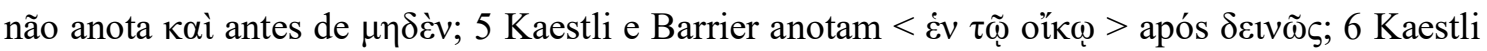

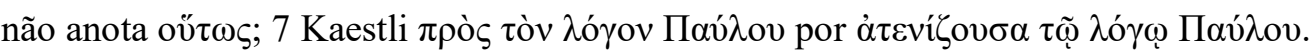

10. Tamiris se aproximou, amando-a ${ }^{190}$ e ao mesmo tempo receando a perturbação dela, e disse: "Tecla, minha noiva, por que você está sentada assim? Que tipo de paixão a deixa atordoada? Volte-se para o seu Tamiris e envergonhe-se." E ainda, sua mãe lhe disse as mesmas coisas: "Filha, por que você fica sentada assim, olhando para baixo, e nada responde, mas fica paralisada?" E eles choraram intensamente. ${ }^{191}$ Tamiris, pela perda da esposa, Teóclia, da filha e as servas, de sua senhora. Então, houve uma grande agitação de pesar na casa. Embora essas coisas acontecessem assim, Tecla não se voltou, ${ }^{192}$ mas estava absorta pelas palavras de Paulo.

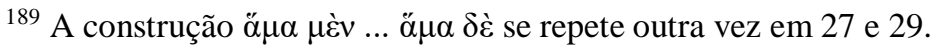

${ }^{190}$ Para o uso de $\varphi \imath \lambda \dot{\varepsilon} \omega$ em $A P T$, cf. Apêndice da seção 1.

${ }^{191}$ Kaestli e Barrier acrescentam após intensamente: "na casa". E os que estavam na casa, isto é, os da família, choravam de dar dó.

${ }^{192}$ Ao manter-se indiferente e silenciosa, ainda que talvez não fosse essa sua intenção, Tecla desrespeita a mãe e o noivo. É uma insubordinação, um comportamento inaceitável para uma moça de boa família. Bremmer (1996, p. 42 e 43), vê nisso um paralelo com o caso de Perpétua, que não atende aos rogos do pai para abandonar o cristianismo, evitando o martírio.
} 


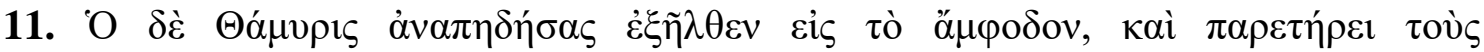

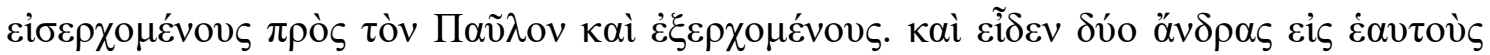

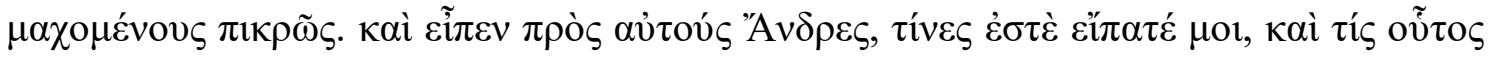

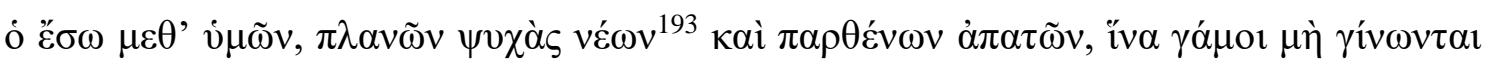

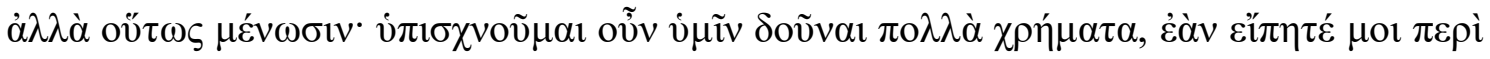

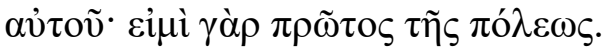

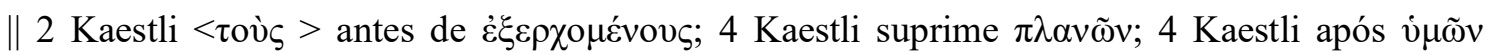

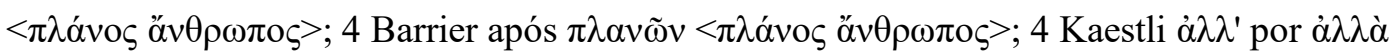

11. Então, Tamiris levantando-se de um salto, saiu para a rua e passou a observar os que entravam na casa para ver Paulo e os que saíam de lá. Ele viu dois homens contendendo amargamente um com o outro. Ele lhes disse: "Senhores, digam-me quem vocês são, e quem é este dentro da casa com vocês, que engana ${ }^{194}$ as almas dos jovens e engoda virgens, para que não se casem, mas permaneçam assim. Se vocês me falarem sobre ele, eu prometo lhes dar muito dinheiro, pois sou o principal $^{195}$ da cidade.

\footnotetext{
${ }^{193}$ Não é possível definir, pela passagem, se são jovens do sexo masculino ou feminino. Mas em 9, "as mulheres e os jovens vão até ele [Paulo]" e em 12 Demas e Hermógenes dizem que Paulo "despoja os jovens de suas esposas e as virgens de seus maridos". Portanto, é bem possível que em 11, vé referindo a rapazes, tendo em vista também a coordenação com parthénon.

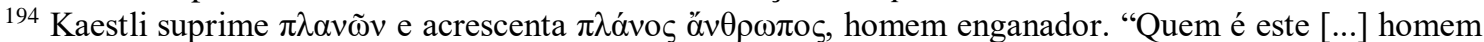
enganador dos jovens e que engoda virgens". Barrier acrescenta as mesmas palavras, mas não suprime $\pi \lambda \alpha \nu \tilde{\omega v}$ : "Quem é este [...] homem enganador, que engana as almas dos jovens e engoda virgens".

${ }^{195}$ Bremmer afirma que $\pi \rho \tilde{\omega} \tau o \varsigma$ é uma terminologia social, uma auto-designação aristocrática, e traduz esse trecho por "a first of the city" (2001, p. 158). Barrier (2008, p. 153) traduz como "the first of the city" e

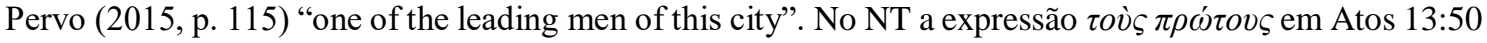
foi traduzida por "os principais da cidade" (ARA, ARC, NVI) e "os homens mais importantes da cidade" (NTLH). Já em Atos 27:7 $\tau \tilde{\omega} \pi \rho \omega ́ \tau \omega ~ \tau \tilde{\eta} \varsigma v \dot{\sigma} \sigma o v$ aparece em português como "ao homem principal da ilha" (ARA); "o principal da ilha" (ARC), "ao homem mais importante da ilha" (ALM21) e "o chefe da ilha"

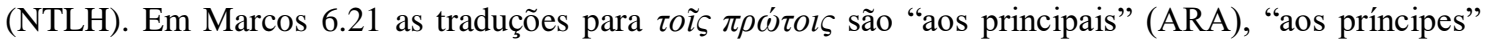
(ARC), "às principais personalidades" (NVI) e "às autoridades da Galileia" (ALM21).
} 


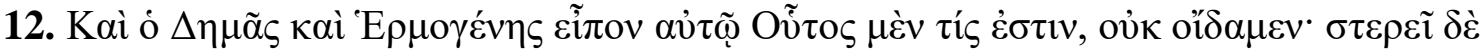

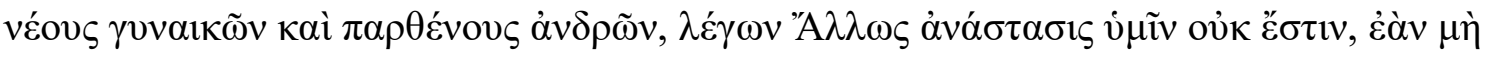

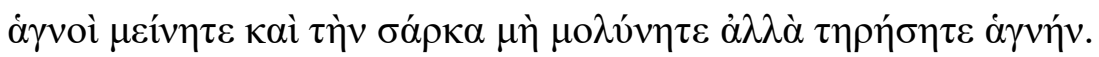

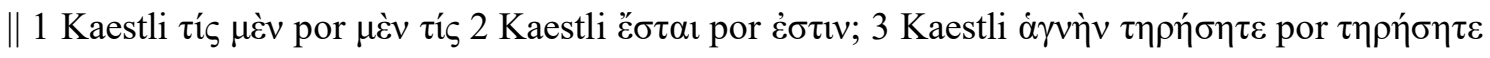
$\dot{\alpha} \gamma v \eta \dot{v} v$

12. E Demas e Hermógenes disseram-lhe: “Quem ele é, não sabemos. Mas ele despoja os jovens de suas esposas e as virgens de seus maridos, dizendo: 'Não há outra maneira de vocês alcançarem a ressureição se não permanecerem castos. E não maculem a carne, mas guardem a castidade' ".

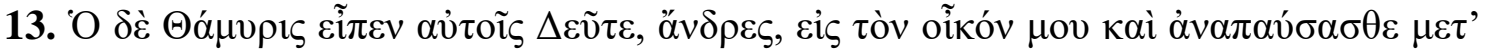

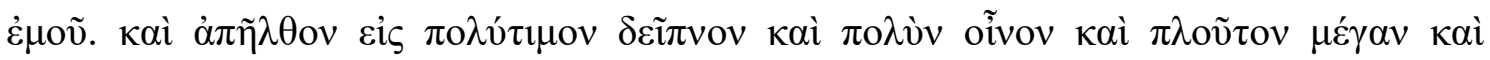

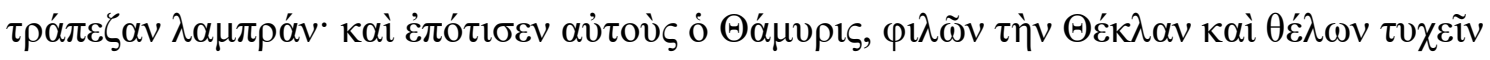

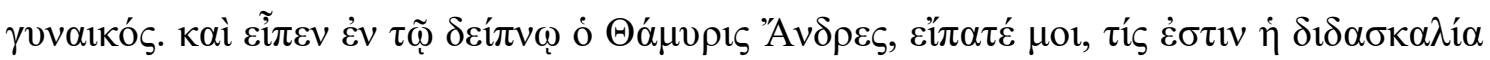

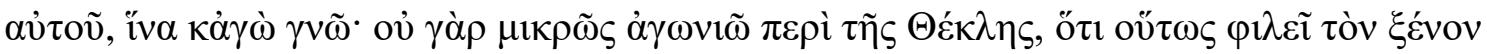

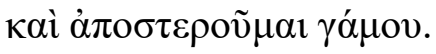

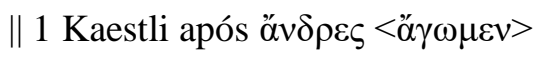

13. Tamiris lhes disse, então: "Senhores, venham para minha casa e descansem comigo." E eles partiram para um banquete muito dispendioso, e muito vinho e grande riqueza e uma mesa magnífica. Tamiris deu-lhes de beber, porque amava Tecla e desejava conseguir uma esposa. E durante o banquete, Tamiris disse: "Senhores, digam-me qual é o ensinamento dele para que eu também saiba. Pois eu estou muito aflito a respeito de Tecla, porque ama o estrangeiro dessa maneira e sou privado do casamento. 


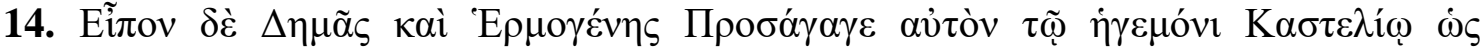

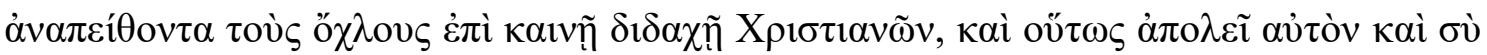

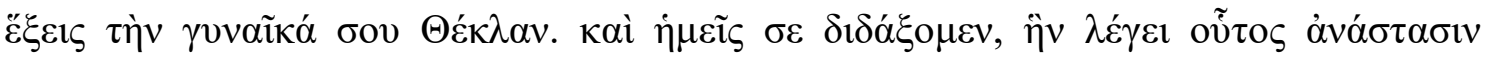

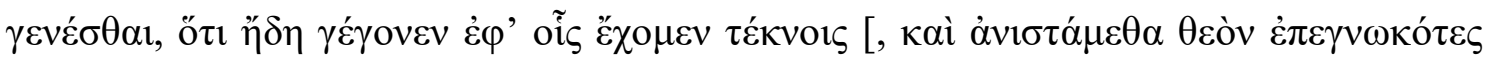
$\dot{\alpha} \lambda \eta \theta \tilde{\eta}]{ }^{196}$

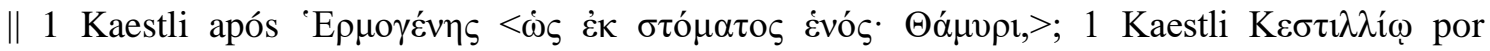

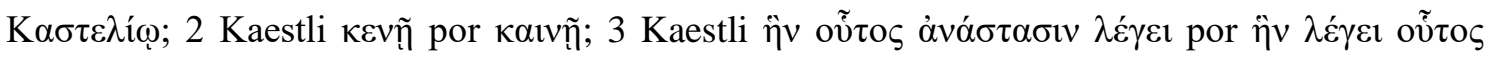

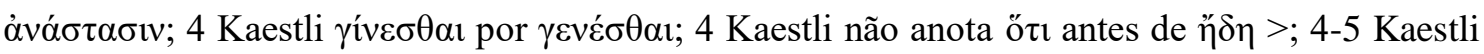

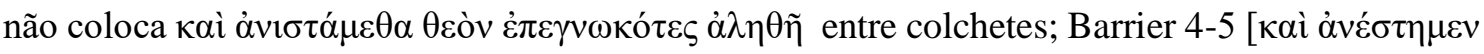

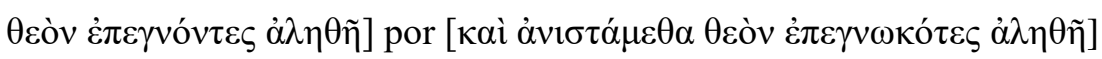

14. Então, Demas e Hermógenes ${ }^{197}$ disseram: "Leve-o ao governador Castélio por seduzir o povo com o novo ${ }^{198}$ ensino cristão. Dessa forma, ele o matará e você terá sua Tecla como esposa. E nós vamos ensinar a você que a ressurreição, a qual ele diz que vai acontecer, já aconteceu ${ }^{199}$ por meio dos filhos que temos [e que ressuscitamos ao conhecer o Deus verdadeiro]".

\footnotetext{
196 “[...] e que ressuscitamos ao reconhecer o Deus verdadeiro”. Essa parte que Lipsius tende a suprimir, Kaestli incorpora.

${ }^{197}$ Kaestli acrescenta após Hermógenes "como de uma boca” (a uma só voz).

198 Antes de "ensino", Kaestli anota $\kappa \varepsilon v \tilde{n}:$ "vã", "vazia”, e não "nova".

199 Aqui os personagens negativos incorporam o ensino combatido em 2 Timóteo 2:18 (ALM21): "Eles se desviaram da verdade, afirmando que a ressurreição já aconteceu, e com isso perverteram a fé em alguns".
} 


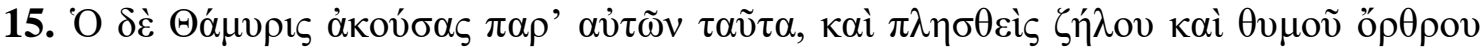

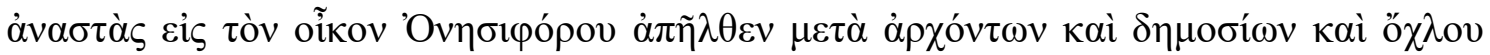

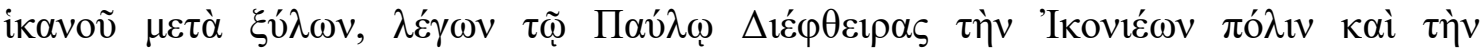

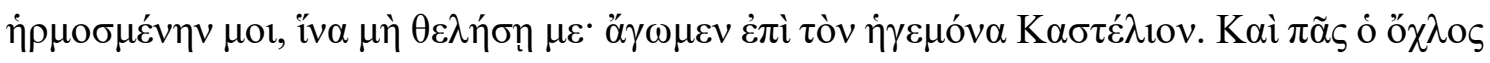

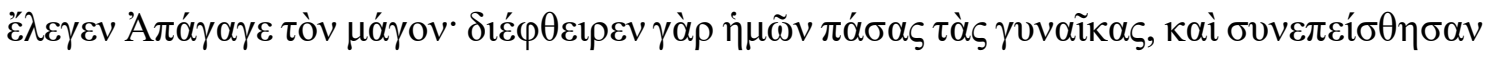

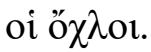

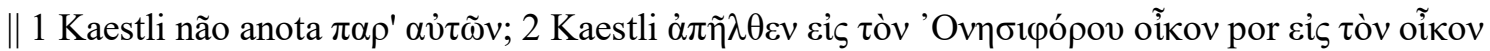

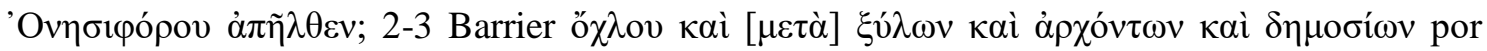

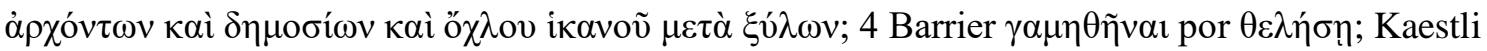

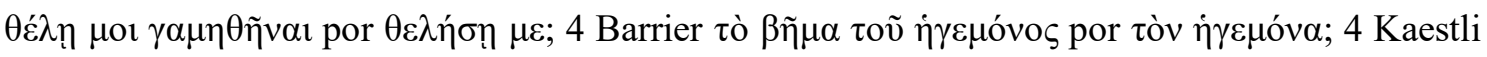

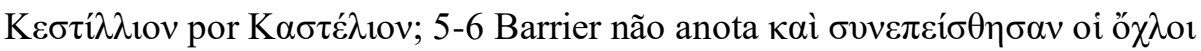

15. Depois de ouvir estas coisas da parte deles, Tamiris, tomado de ciúmes e de ira, levantando-se de madrugada, foi à casa de Onesíforo junto com os magistrados e servidores públicos e com muita gente com pedaços de pau, ${ }^{200}$ e disse a Paulo: "Você corrompeu a cidade dos Icônios e a minha noiva, para que não me queira mais. ${ }^{201}$ Vamos até o governador Castélio!" 202 E todo o povo dizia: "Prenda o feiticeiro, porque corrompeu todas as nossas mulheres e as multidões são persuadidas!"203

\footnotetext{
200 Comparar com Marcos 14:43.

${ }^{201}$ Barrier anota "para que não case mais comigo". Já Kaestli, "para que não queira casar comigo".

${ }^{202}$ Não há tribunal no texto de Lipsius, mas Barrier anota "vamos até o tribunal do governador Castélio"

${ }^{203}$ Barrier suprime "e as multidões são persuadidas".
} 


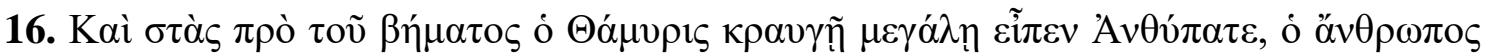

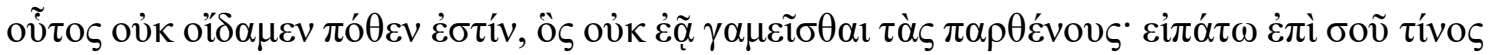

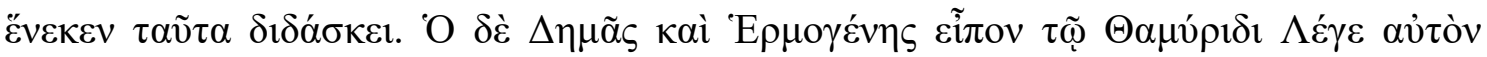

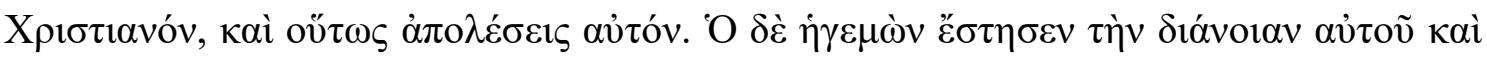

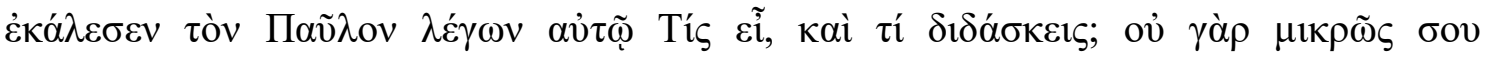

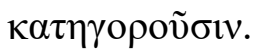

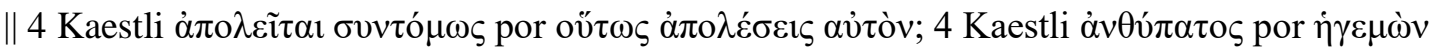

16. De pé, diante do tribunal, Tamiris disse bem alto: 204 "Procônsul, não sabemos de onde é esse homem, o qual não permite que as virgens se casem. Que ele diga em sua presença por que ele ensina essas coisas." Mas Demas e Hermógenes disseram a Tamiris: "Fale que ele é cristão ${ }^{205} \mathrm{e}$, assim, você acabará com ele!” Mas o governador manteve o pensamento dele e chamou Paulo, dizendo-lhe: "Quem você é e o que ensina? As acusações contra você não são pequenas."

\footnotetext{
${ }^{204} \mathrm{Ou}$, "gritou bem alto". Descrevendo os procedimentos de um tribunal romano, Bremmer (1996, p. 47) diz que a acusação deveria ser em alta voz, o que explicaria a atitude de Tamiris.

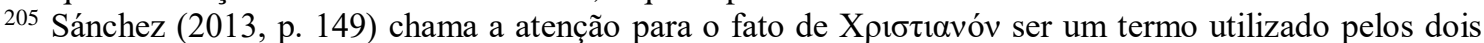
traidores de Paulo. No NT a palavra aparece apenas três vezes (Atos 11:26; 26:28 e 1 Pedro 4:16), sendo que nas duas primeiras passagens é proferida por pessoas de fora do círculo cristão.
} 


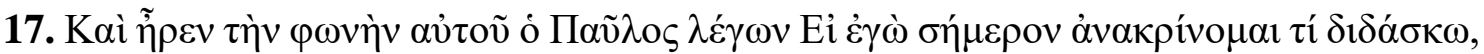

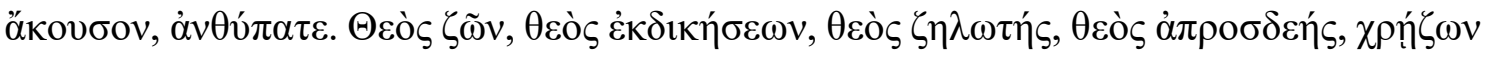

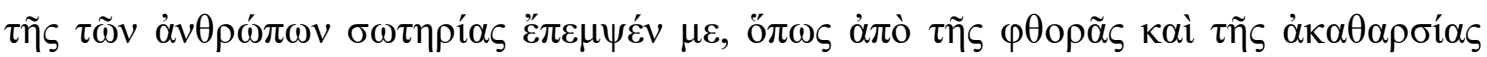

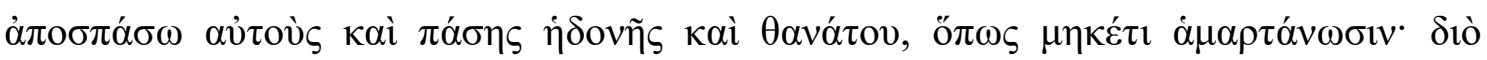

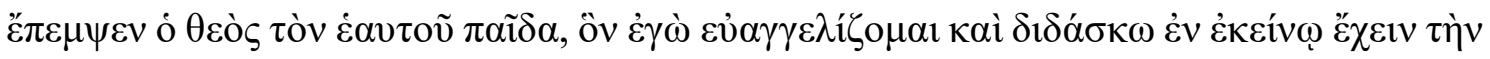

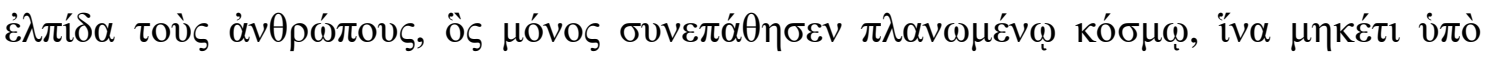

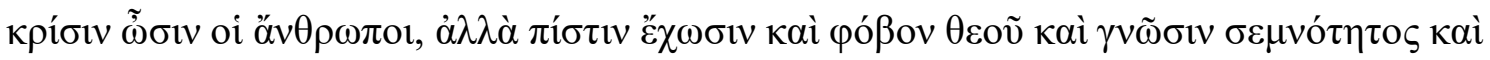

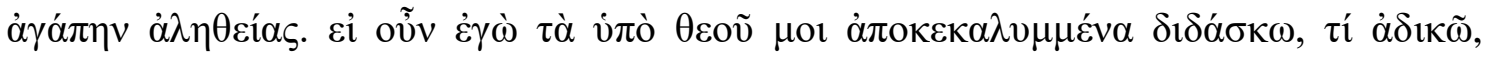

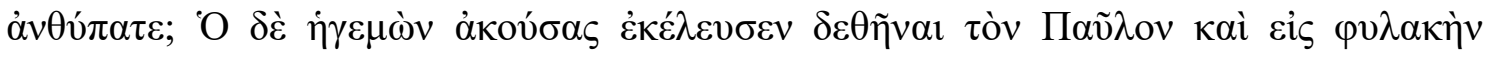

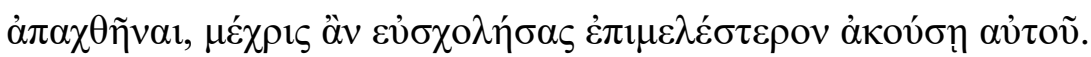

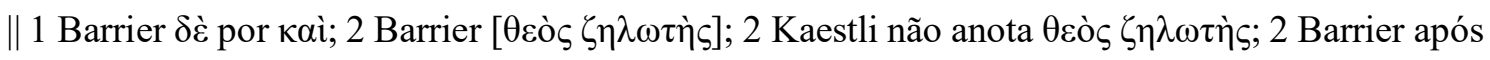

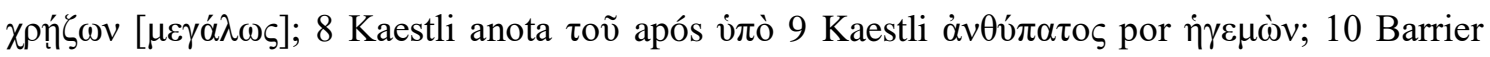
$\beta \lambda \eta \theta \tilde{\eta} v \alpha \iota$ por $\dot{\alpha} \pi \alpha \chi \theta \tilde{\eta} v \alpha l ; 10$ Barrier $\kappa \alpha \lambda \tilde{\omega} \varsigma$ por $\dot{\pi} \pi \mu \varepsilon \lambda \varepsilon \dot{\sigma} \sigma \varepsilon \rho \circ \nu$

17. Então, Paulo ergueu a sua voz dizendo: "Se hoje sou julgado por aquilo que ensino, ouça, Procônsul. O Deus vivo, Deus das vinganças, Deus zeloso, Deus que se basta, desejando a salvação dos homens, enviou-me, para que eu os arranque da ruína e da depravação e de todo prazer e da morte, a fim de que não pequem mais. Eis porque Deus enviou o seu próprio filho, o qual eu anuncio como boa nova e ensino os homens a terem esperança nele, o qual é o único que se compadece do mundo desviado, a fim de que os homens não mais estivessem sob juízo, mas tivessem fé e temor de Deus e conhecimento da dignidade ${ }^{206} \mathrm{e}$ amor da verdade ${ }^{207}$. Então, se eu ensino as coisas reveladas por Deus a mim, que injustiça cometo, ${ }^{208}$ procônsul?" Então, depois de ouvir, o governador ordenou que atassem Paulo e o levassem para a prisão até que tivesse tempo livre para ouvi-lo com mais cuidado. ${ }^{209}$

\footnotetext{
${ }^{206}$ Dignidade de Deus ou "do respeito a ele".

${ }^{207} \dot{\alpha} \gamma \alpha \dot{\alpha} \pi \eta v \dot{\alpha} \lambda \eta \theta \varepsilon i ́ \alpha \varsigma$. Talvez essa expressão seja uma tentativa de remeter à linguagem paulina que aparece em algumas cartas, conectando a salvação ao amor da verdade ou ao conhecimento dela como em 2 Tessalonissenses 2:10 (ARC): "porque [os que perecem] não receberam o amor da verdade ( $\dot{\alpha} \gamma \alpha \dot{\alpha} \pi \eta v \tau \tilde{\eta} \varsigma$ $\dot{\alpha} \lambda \eta \theta \varepsilon i ́ \alpha \varsigma)$ para se salvarem"; e em 1 Timóteo 2:4 (ARC): "Que quer que todos os homens se salvem, e venham ao conhecimento da verdade ( $\dot{\varepsilon} \pi \dot{\gamma} \gamma v \omega \sigma v v \dot{\alpha} \lambda \eta \theta \varepsilon \dot{\alpha} \alpha \varsigma)$ ".

${ }^{208}$ Pervo (2014, p. 122) compara a defesa de Paulo à de Sócrates. Ambos apelam à revelação divina como justificativa para a pregação de suas ideias.

${ }^{209}$ Não é difícil notar a semelhança entre essa passagem e Atos 24:25 em que Félix, governador romano

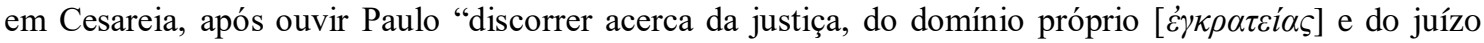
vindouro, teve medo e disse: 'Basta, por enquanto! Pode sair. Quando achar conveniente, mandarei chamálo de novo" ".
} 


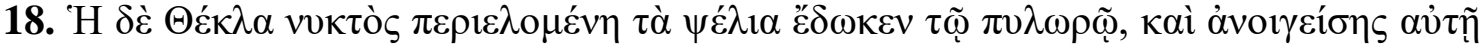

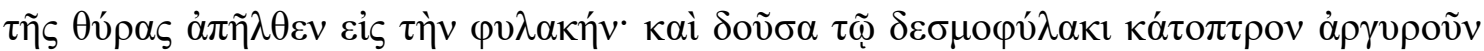

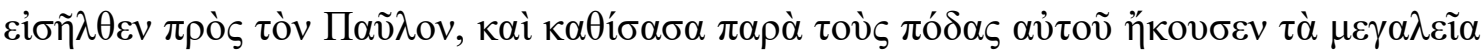

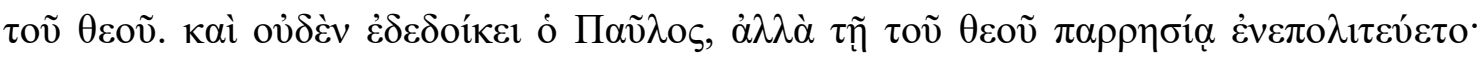

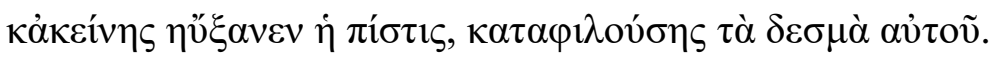

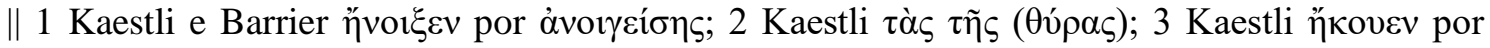

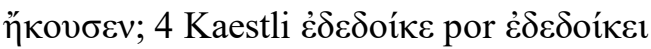

18. À noite, Tecla retirando de si os braceletes ${ }^{210}$ deu-os ao porteiro e, com a porta aberta para ela, foi à prisão. Depois de ter dado um espelho de prata ao carcereiro, foi até Paulo e, assentando-se a seus pés, ouviu as grandezas de Deus. E Paulo nada temia, mas, pela coragem vinda de Deus, agia como um cidadão livre. E sua fé crescia, enquanto beijava ternamente as algemas dele.

\footnotetext{
${ }^{210}$ Para Pervo (2014, p. 126) a renúncia ao mundo (na terceira bem-aventurança), é efetivada por Tecla ao se dispor do bracelete e dos espelhos, os quais eram símbolos de riqueza e feminilidade. Tal ato representaria a renúncia à posição social e ao gênero femino (sexualidade). Assim, "Tecla estaria "descartando a aparência de liberdade e riqueza pela realidade de autêntica liberdade e riqueza espiritual".
} 


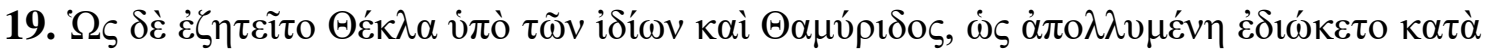

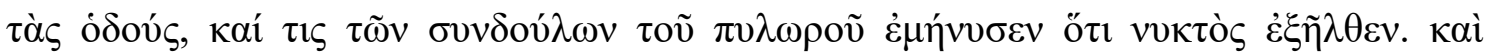

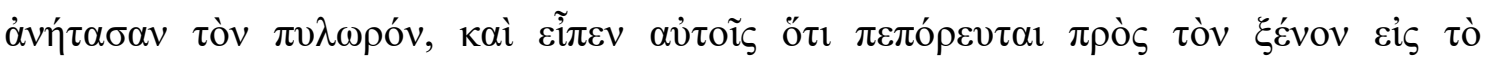

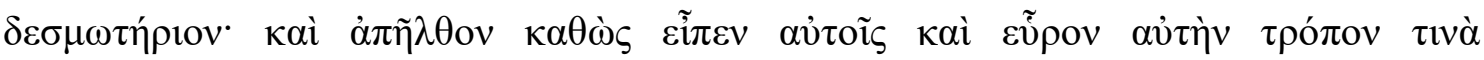

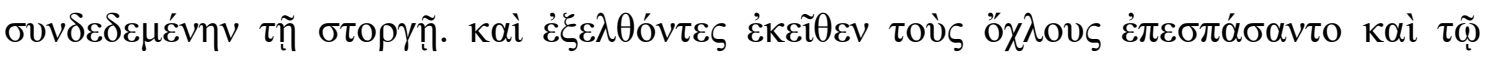

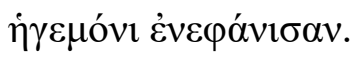

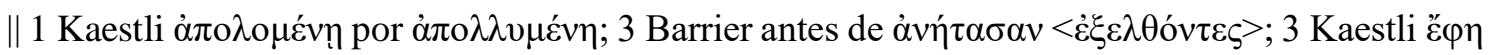

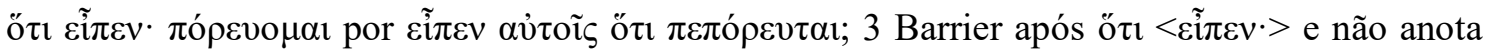

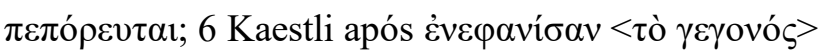

19. Ao mesmo tempo, Tecla estava sendo procurada pelos seus e por Tamiris, buscada pelas ruas como se estivesse perdida. E um dos escravos companheiros do porteiro, revelou que ela saíra durante a noite. Então, eles interrogaram o porteiro e ele lhes disse que ela ${ }^{211}$ havia ido à prisão para ver o estrangeiro. E partiram conforme ele lhes falou e a encontraram, de certo modo, aprisionada pelo afeto. Após partirem dali, incitaram a multidão, e contaram [tudo] ao governador.

${ }^{211}$ Kaestli anota "e disse que ela declarou: vou à prisão" e Barrier "disse-lhes que ela declarou: eu vou à prisão". Ambas as variações indicam uma atitude proativa de Tecla. 


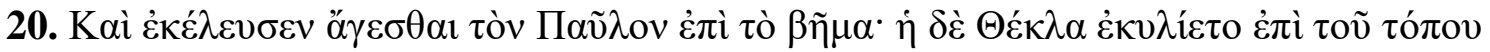

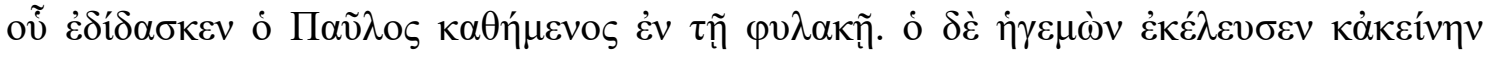

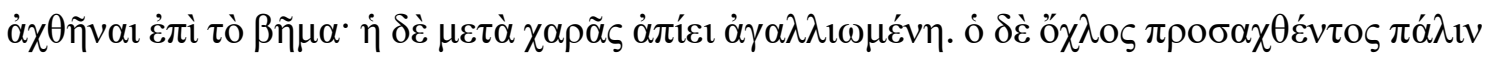

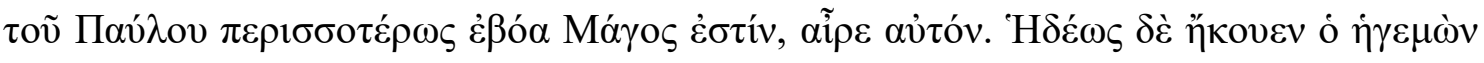

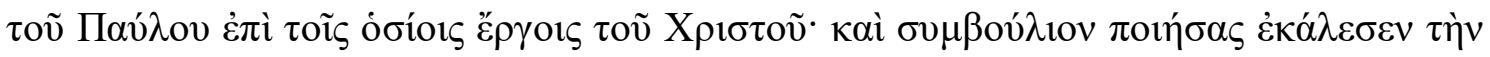

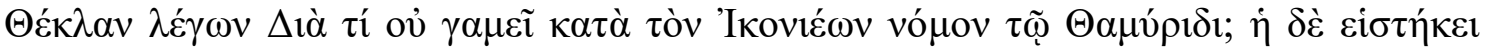

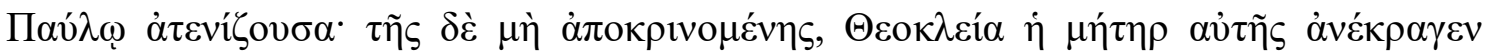

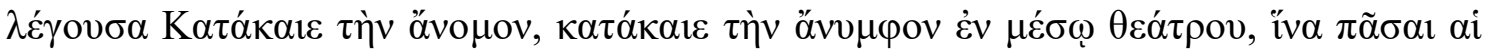

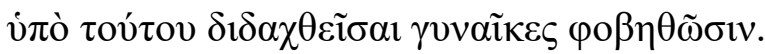

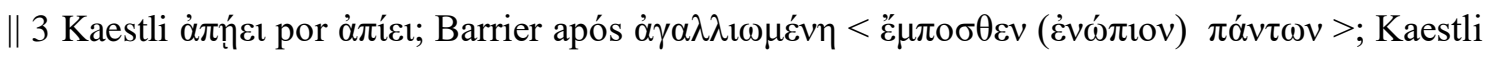

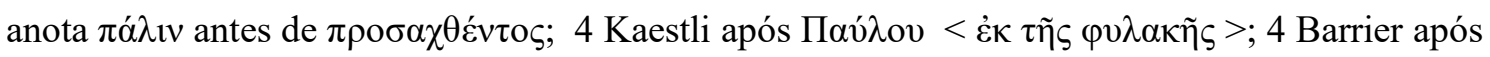

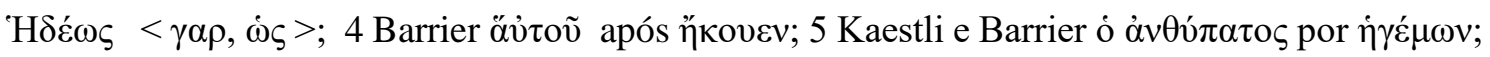

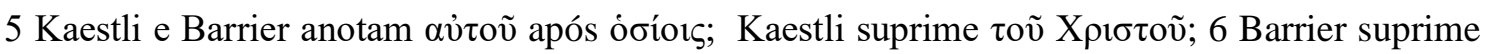

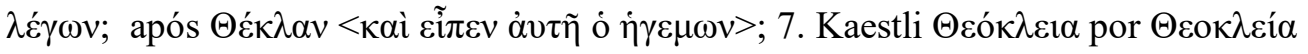

20. E ele ordenou que conduzissem Paulo ao tribunal. E Tecla rolava ${ }^{212}$ sobre o lugar na prisão onde Paulo, sentado, ensinara. E o governador ordenou que também fosse trazida ao tribunal. E ela, regozijando-se, partiu com alegria. E a multidão, depois que Paulo foi conduzido de novo, gritava ainda mais: "Ele é um feiticeiro! Fora com ele!" Com prazer, o governador ouvia Paulo acerca dos santos feitos de Cristo e, depois de reunir o conselho, chamou Tecla e disse: "Por que você não se casa com Tamiris, de acordo com a lei dos Icônios?" Ela levantou-se, com o olhar fixo em Paulo. Como não respondesse, Teóclia, a mãe dela, gritou, dizendo: "Queime a transgressora! Queime no meio do teatro a que se recusa a casar-se para que todas as mulheres que aprenderam com ele tenham medo.”

\footnotetext{
212 Segundo $D G P$, o verbo $\kappa v \lambda i ́ \omega$ na voz média significa rolar-se, girar sem cessar, ir e vir, agitar-se. A comparação com Marcos 9:20, onde o mesmo verbo descreve o ato do menino endemoninhado revolvendose no chão, ajuda a visualizar a ação de Tecla, que parece ter um ataque de nervos. Provavelmente o autor usou o vocábulo para expressar a intensa comoção da jovem.
} 


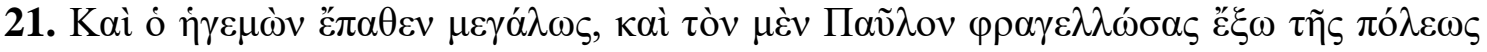

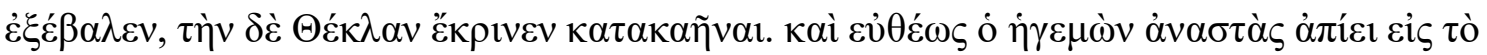

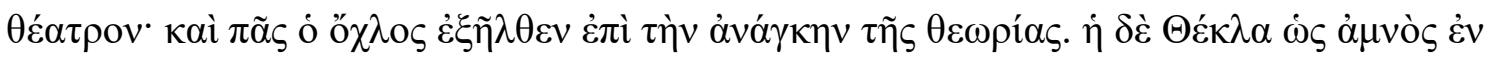

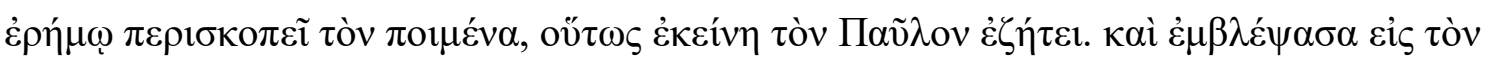

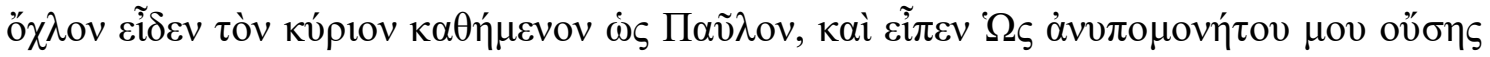

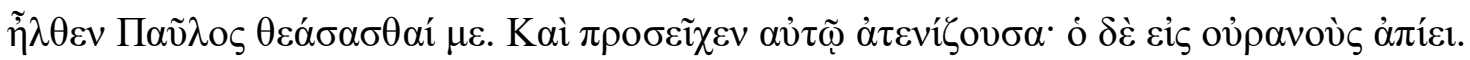

$\| 1$ Kaestli suprime $\mu \varepsilon \dot{v} v$; Barrier $\mu \alpha \sigma \tau$

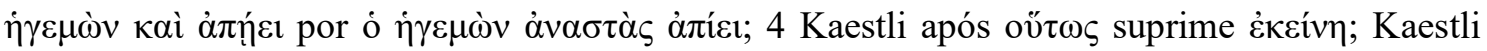

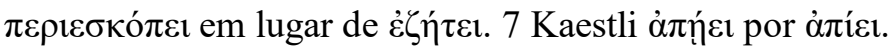

21. Mas o governador sofreu grandemente e, por um lado, após ter feito açoitar Paulo, expulsou-o da cidade, e por outro, sentenciou que Tecla deveria ser queimada. ${ }^{213}$ Imediatamente, o governador, tendo se levantado, partiu para o teatro e toda a multidão seguiu para o violento ${ }^{214}$ espetáculo. Mas Tecla, como a ovelha no deserto olha ao redor em busca do pastor, assim ela procurava Paulo. E, após olhar para a multidão, viu o Senhor ali sentado como Paulo, e disse: "Como se eu não fosse suportar, Paulo veio contemplar-me." E ficou atenta a ele, fixando o olhar, mas ele partiu para o céu.

\footnotetext{
213 Além do martírio de Tecla ser uma, digamos, necessidade da narrativa, para criar tensão, Bremmer (1996, p. 48) oferece uma explicação bastante plausível para sentenças tão desproporcionais. Paulo era um cidadão romano e isso lhe dava certa proteção. Tecla, sem esse privilégio, não teria como escapar da pena máxima.

${ }^{214}$ Outra opção seria "a obrigação do espetáculo”, como traduz Barrier.
} 


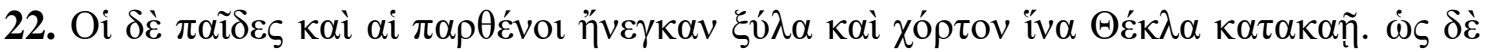

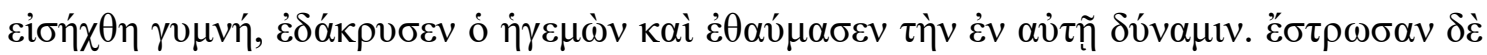

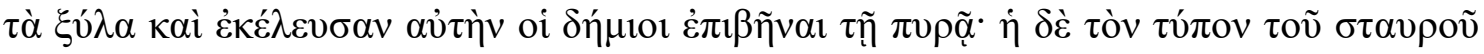

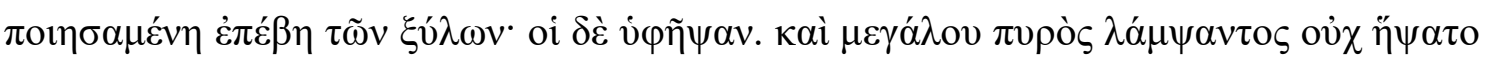

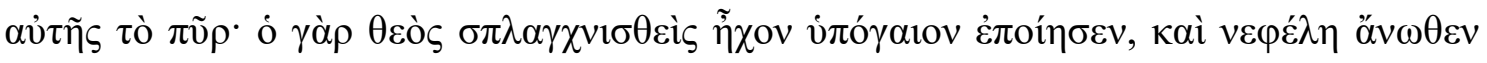

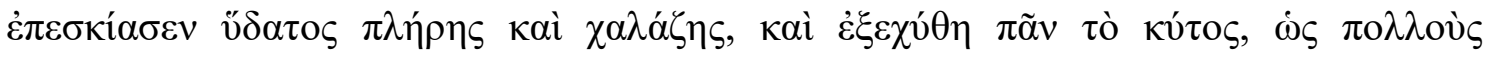

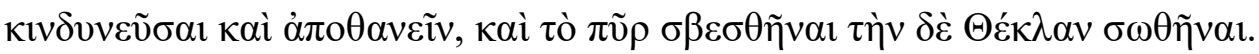

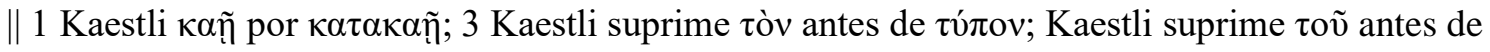

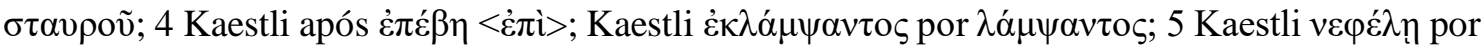

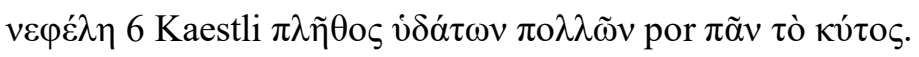

22. E os jovens e as virgens carregavam lenha e forragem para que Tecla fosse queimada. E quando ela foi conduzida nua ${ }^{215}$, o governador chorou e admirou-se da força que havia nela. Os carrascos arrumaram a lenha e mandaram que ela subisse na pira. E ela, após fazer o sinal ${ }^{216}$ da cruz, subiu sobre a lenha. E eles atearam fogo. Mas, mesmo com uma grande chama ardendo, o fogo não a tocava. Então, Deus, tendo se compadecido, provocou um estrondo subterrâneo e cobriu de sombra o alto com uma nuvem cheia de água e granizo, e todo o seu conteúdo foi derramado de tal maneira que muitos ficaram em perigo e morreram, o fogo foi apagado e Tecla foi salva.

215 Pervo (2014, p. 133) vê aqui uma distinção importante entre Tecla e as heroínas dos romances: assim como a jovem de Icônio, elas passam usualmente por ameaças de morte, "mas nunca são exibidas nuas no teatro".

${ }^{216}$ Cf. apêndice da seção 22. 


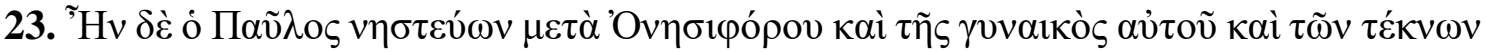

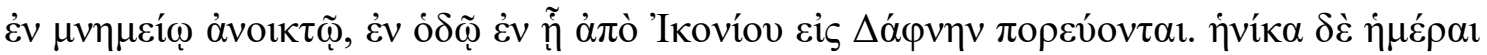

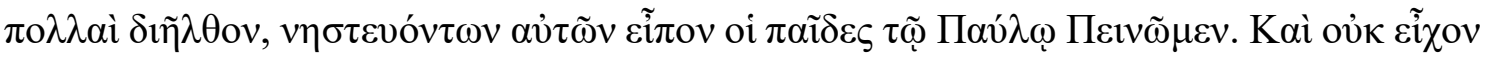

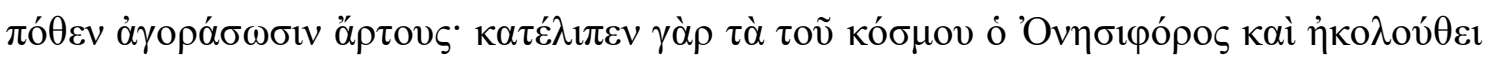

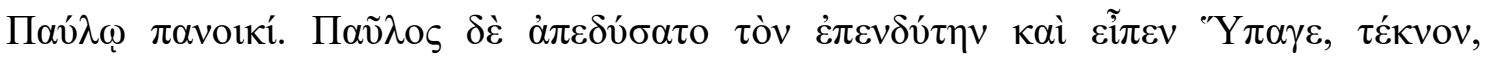

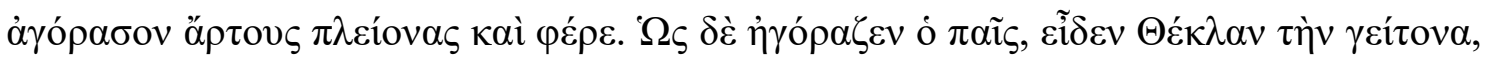

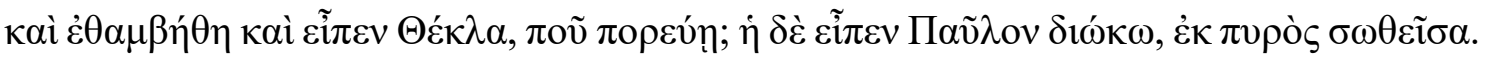

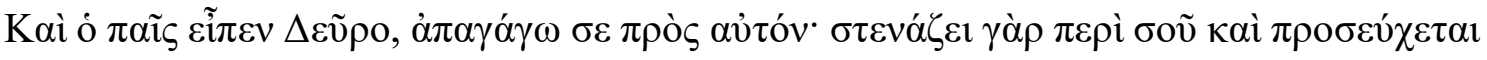

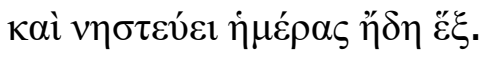

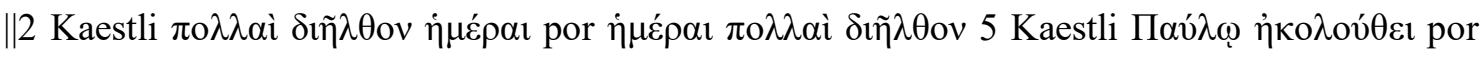

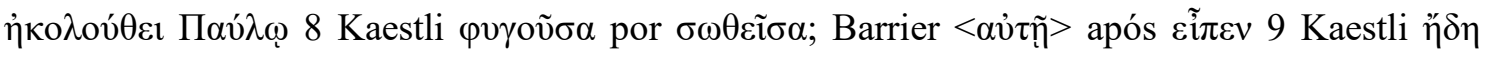

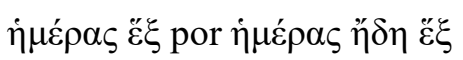

23. Paulo estava jejuando com Onesíforo, a esposa e os filhos dele em uma tumba aberta, no caminho que vai ${ }^{217}$ de Icônio a Dafne. Quando transcorreram muitos dias, como estavam jejuando, os meninos disseram a Paulo: “Estamos famintos!” E eles não tinham recursos para comprar pão, pois Onesíforo havia deixado as coisas do mundo e seguia a Paulo com toda a família. Então Paulo despojou-se do manto e disse: "Leve, menino, compre o máximo de pães possível e traga-os." Então, enquanto o menino comprava, viu Tecla, sua vizinha, e espantou-se e disse: “Tecla, onde você vai?" E ela disse: "Estou à procura de Paulo desde que fui salva da fogueira." E o menino disse: "Venha aqui, eu a levo até ele. Pois ele suspira por você e ora e jejua já há seis dias.”

${ }^{217}$ No grego "vão". É o caminho pelo qual as pessoas vão de Icônio a Dáfne. 


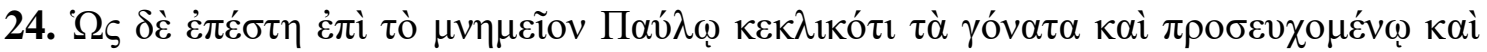

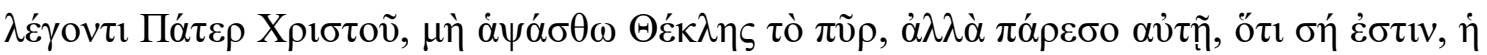

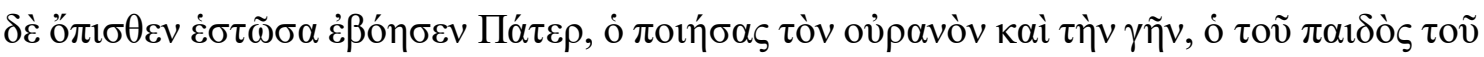

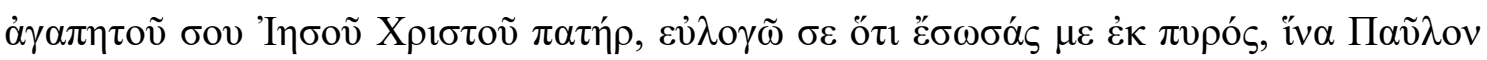

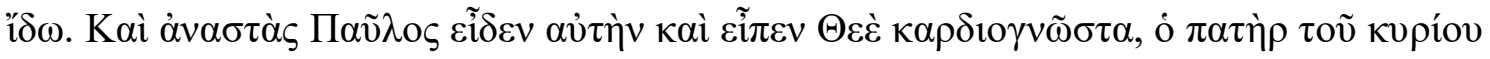

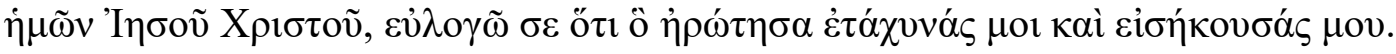

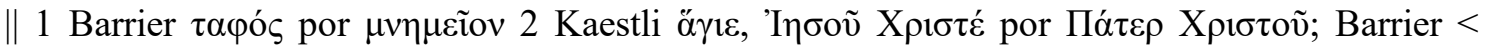

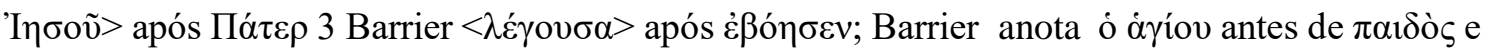

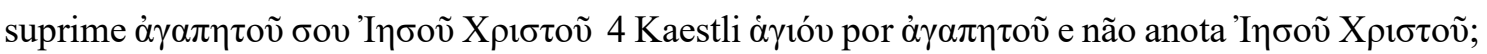

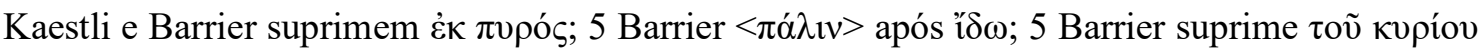

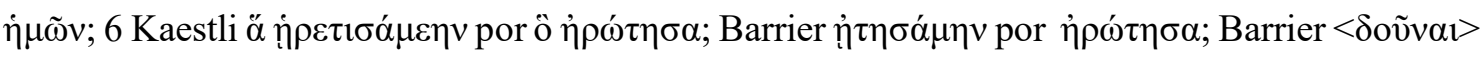

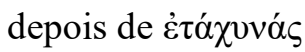

24. Assim, ela se colocou junto à tumba, ao lado de Paulo ${ }^{218}$ que estava de joelhos dobrados, orando e dizendo: "Pai de Cristo, que o fogo não atinja Tecla, mas esteja com ela, porque ela é sua". E ela, em pé atrás dele, clamou: “Ó pai, que criou o céu e a terra, o pai de seu filho amado, Jesus Cristo, eu o louvo porque salvou-me da fogueira, para que eu visse Paulo". Levantando-se, Paulo a viu e disse: "Deus, conhecedor dos corações, pai do nosso senhor Jesus Cristo, eu o louvo porque me ouviu e fez rapidamente ${ }^{219}$ o que eu pedi."

\footnotetext{
${ }^{218}$ A cena do reencontro do par de protagonistas, que se conclui em 25 , marca o final do primeiro ciclo de $A P T$.

${ }^{219}$ Aqui parece uma ironia, já que ele estava orando há seis dias...
} 


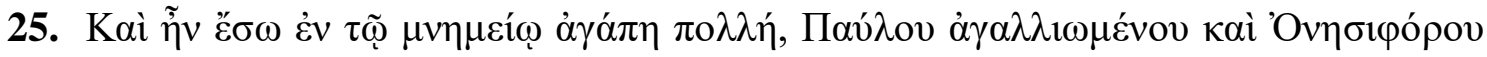

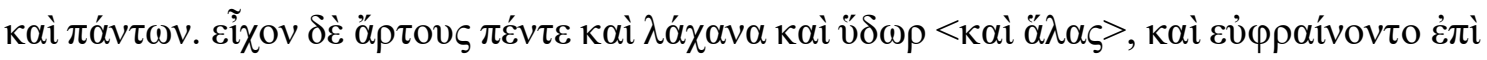

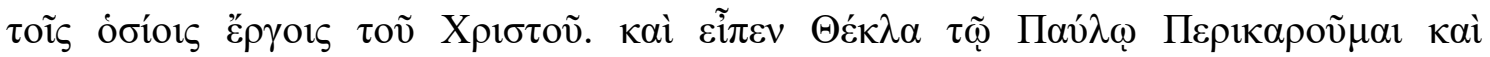

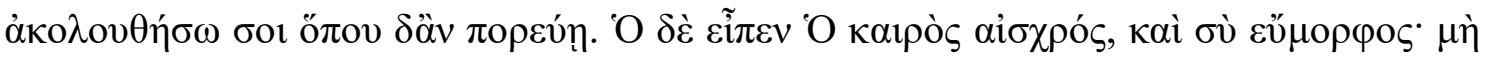

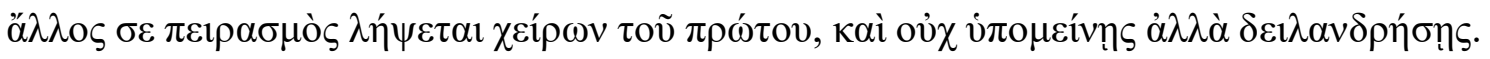

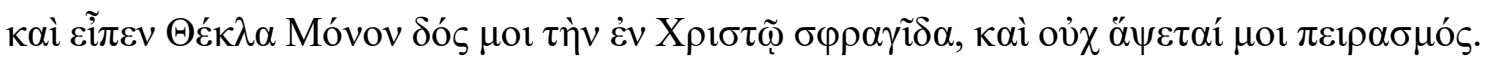

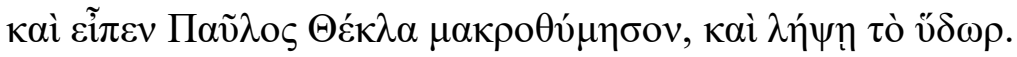

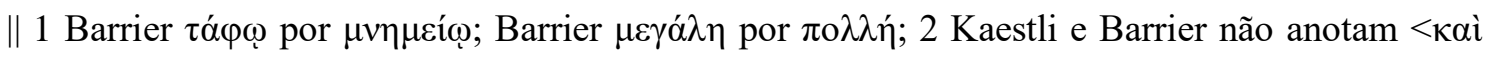

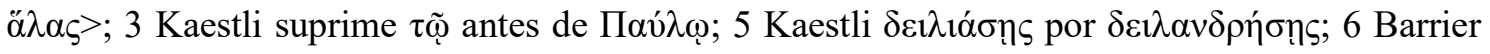

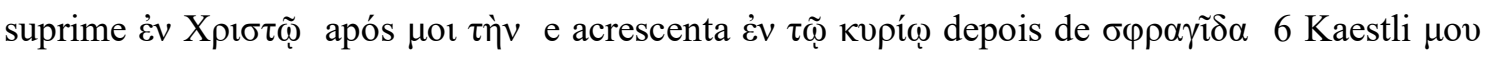

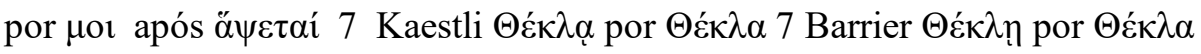

25. E houve muito amor ${ }^{220}$ no interior do túmulo. Paulo se regozijava, bem como Onesíforo e todos os demais. E eles tinham cinco pães, legumes e água ${ }^{221}<$ sal>, e alegraram-se com as santas obras de Cristo. E Tecla disse a Paulo: "Eu vou cortar o cabelo $^{222}$ e segui-lo por onde você andar." Mas ele disse: "O tempo é torpe ${ }^{223}$, e você é bonita. Não sobrevenha a você outra provação pior que a primeira, e você não resista, mas acovarde-se." Mas Tecla disse: "Dê-me apenas o selo de Cristo ${ }^{224}$, e a provação não me tocará.” E Paulo disse: “Tecla, seja perseverante e você receberá a água."225

\footnotetext{
${ }^{220}$ É indiscutível que aquela foi uma refeição festiva. Por isso DUNN (2006, p. 86) sugere que $\dot{\alpha} \gamma \alpha \dot{\pi} \pi \eta$ aqui se relaciona à tradicional festividade cristã que levava esse nome, caracterizada pela refeição tomada em comum. Barrier (2008, p. 214) também ventila essa possibilidade sem, no entanto, adotá-la em sua tradução. ${ }^{221}$ A refeição é bastante frugal, consistindo de alimentos simples. Note-se a ausência de carne e de vinho, o que pode ser explicado por uma restrição dietética ou pela falta de recursos para adquirir esses itens - um indício disso é que Paulo troca seu manto por pão. Em Romance de Esopo, texto da mesma época, Esopo, que é um escravo, divide com a sacerdotisa de Ísis, que se perdera no campo, sua refeição: pão, azeitonas, alface que colhe no mato e água do riacho (Esopo, 2017: 204). Isso sugere que essa fosse uma refeição usual para os pobres. Para uma discussão sobre o aquarianismo, cf. Dunn (2006, p. 86-87).

${ }^{222}$ Talvez para evitar que sua beleza atraia o desejo dos homens.

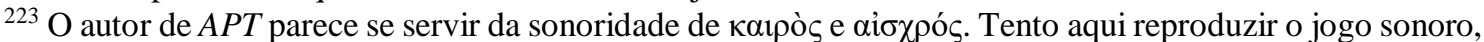

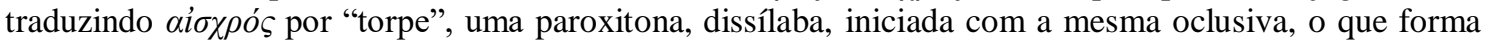
"tempo torpe". Procurei enfatizar também o aspecto sórdido e até perigoso da moralidade da época para o qual Paulo chama a atenção de Tecla, prevendo talvez o assédio que ocorrerá na seção 26. Já Pervo (2014, p. 138) investe no contraste "Os tempos são tão feios e você é tão bonita", uma opção bem interessante, que enfatiza o risco que uma mulher bonita correria tornando-se uma missionária itinerante, como o apóstolo. No NT em português, as diversas versões traduzem as ocorrências de aiøðৎós pricipalmente por "vergonhoso", "indecente", "torpe".

${ }^{224}$ Para a expressão "selo de Cristo", como um indício da época de composição do texto, cf. Apêndice da seção 25.

225 "A água", promessa do batismo.
} 


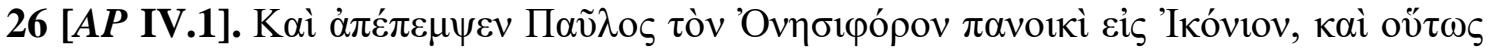

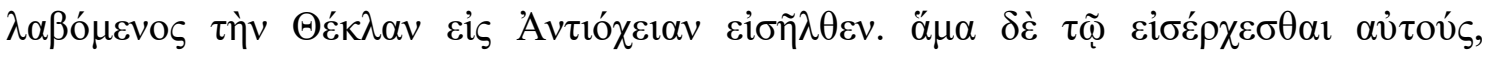

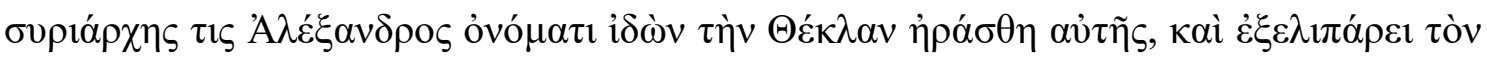

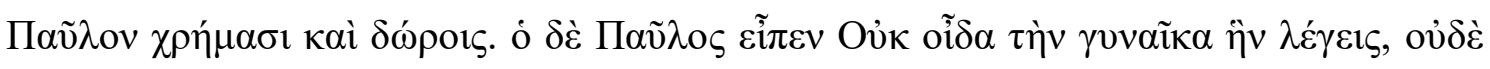

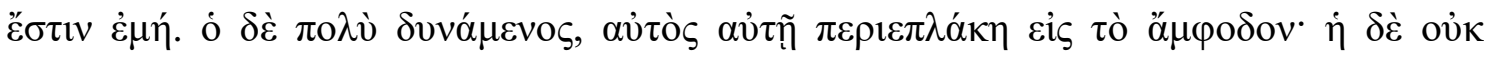

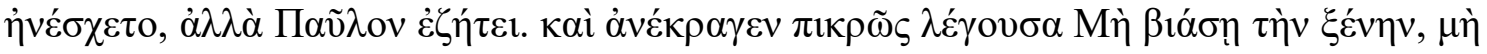

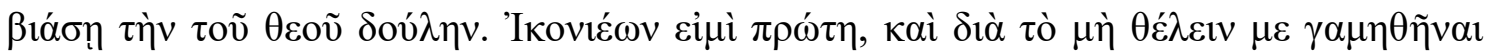

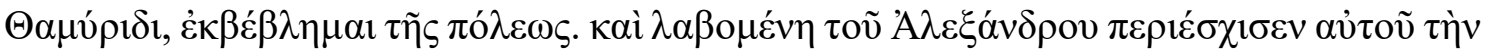

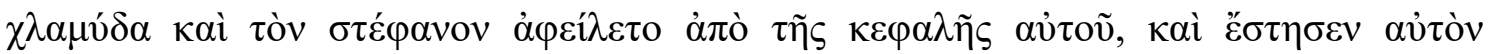
$\theta \rho i ́ \alpha \mu \beta o v$.

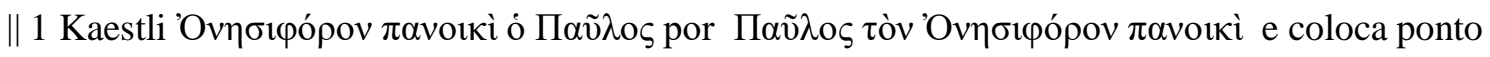

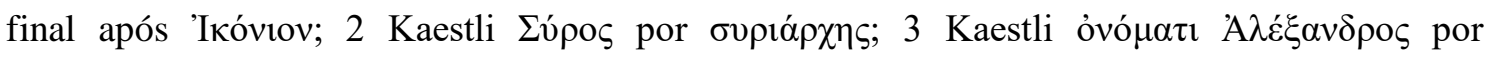

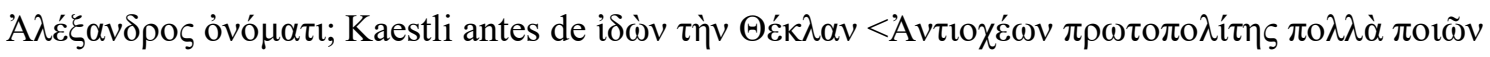

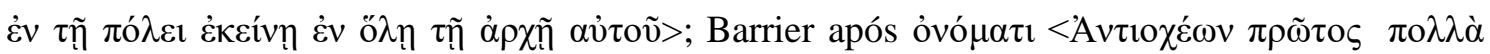

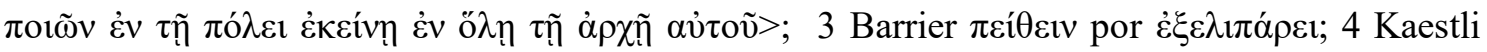

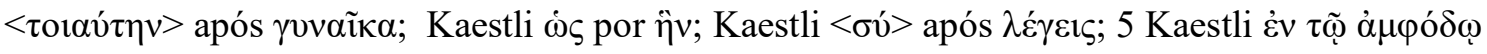

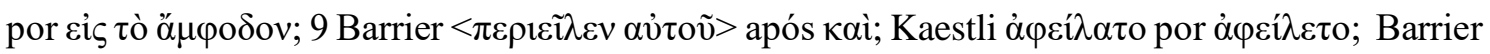

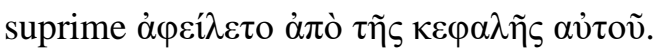

26. E Paulo enviou Onesíforo com toda a família de volta para Icônio, e, tomando Tecla, partiu para Antioquia. Mas, no momento em que entravam [na cidade], um siriarca ${ }^{226}$ chamado Alexandre, ${ }^{227}$ vendo Tecla, apaixonou-se por ela. E tentou convencer ${ }^{228}$ Paulo com dinheiro e presentes. Mas Paulo disse: "Não conheço a mulher da qual fala, ela não é minha." 229 E ele [Alexandre], tendo muito poder, ${ }^{230}$ agarrou-a na rua. E ela não aceitou, mas procurava Paulo. Ela gritava, falando amargamente: "Não agrida a estrangeira! Não agrida a serva de Deus! Eu sou uma principal ${ }^{231}$ de Icônio e, por não querer me casar com

\footnotetext{
${ }^{226}$ Cf. apêndice A, seção 26. Siriarca (p. 126).

${ }^{227}$ Após Alexandre, Kaestli acrescenta "cidadão de destaque em Antióquia, muito atuante naquela cidade pela sua liderança". Barrier acrescenta trecho praticamente idêntico e traduz prótos por "membro da liderança".

228 Verbo usado na seção 1, em relação a de Demas e Hermógenes. Uma opção válida também é “adulou”. Uma mulher andando na companhia de um homem pela cidade, trazia dúvidas sobre sua moral. É possível que Alexandre a tenha tomado por uma escrava. Por isso procura negociá-la com Paulo, presumindo que este fosse o proprietário dela.

${ }^{229}$ Para discussões o desaparecimento de Paulo e a defesa Tecla, cf. p. 35 e 36, 39 e 40.

${ }^{230}$ Dunamai parece se relaciona ao poder de Alexandre, devido a sua posição social, que à sua força física. 231 Tecla usa o mesmo termo, prótos, que Tamiris usou para referir-se a si mesmo como membro da elite da cidade e usado também para descrever Alexandre, na versão utilizada por Barrier. Cf. nota 221, p. 76.
} 
Tamiris, fui banida da cidade." E, agarrando o manto ${ }^{232}$ de Alexandre, rasgou-o e tirou a coroa $^{233}$ da cabeça dele, e ficou em pé, e triunfou ${ }^{234}$ sobre ele. ${ }^{235}$

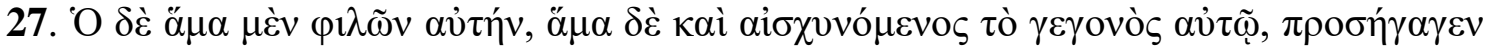

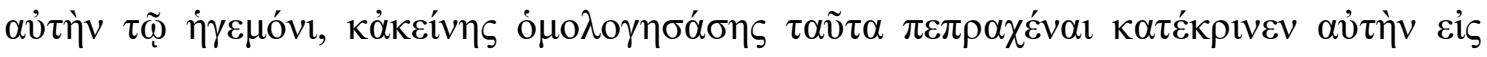

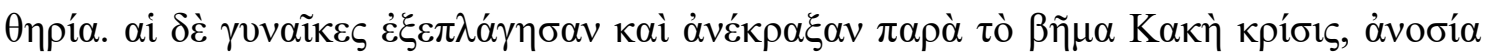

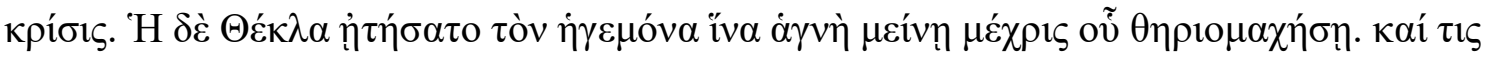

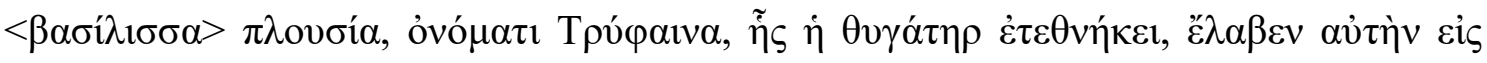

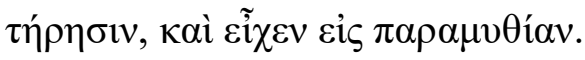

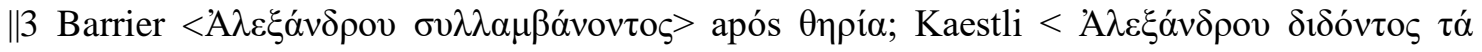

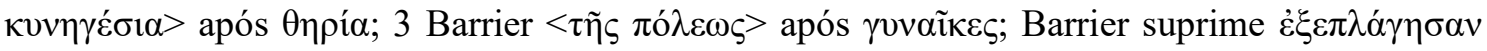

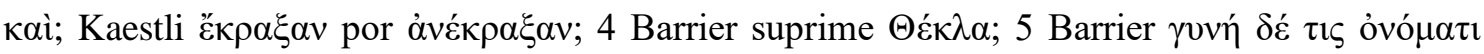

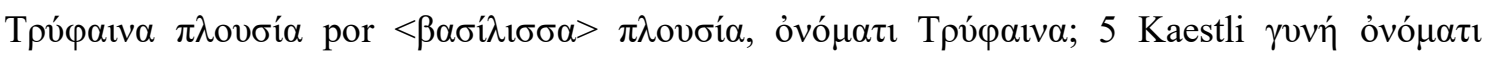

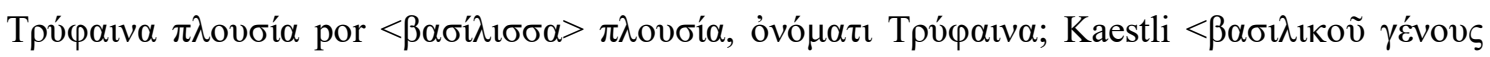

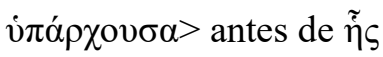

27. Ele, amando-a e, ao mesmo tempo, sentindo vergonha pelo que lhe acontecera, conduziu-a ao governador. Quando ela admitiu ter feito essas coisas, ele a sentenciou às feras. ${ }^{236}$ Mas as mulheres, ficaram perplexas e gritaram perto do tribunal: "Sentença má! Sentença ímpia!” E Tecla suplicou ao governador para que ela permanecesse casta até a luta contra as feras. E uma <rainha> rica chamada Trifena, ${ }^{237}$ cuja filha havia morrido, tomou-a sob sua guarda, e teve-a para seu consolo.

\footnotetext{
${ }^{232}$ Sobre a clâmide, cf. apêncice A, seção 26. Clâmide (p. 126).

${ }^{233}$ Sobre a coroa e a função pública de Alexandre, cf. apêncice A, seção 26. Coroa (p. 126).

${ }^{234}$ Talvez uma alusão a 2 Coríntios 2:14: "Mas, graças a Deus, que em Cristo sempre nos conduz em triunfo $[\theta \rho ı \mu \beta \varepsilon v ́ o v \tau \imath] "$.

${ }^{235}$ Outra tradução possível: "e o expôs à zombaria". A humilhação de Alexandre por Tecla é comparada à de um prisioneiro de guerra sujeito à derrisão pública. Ela o reduz à sua própria (aparente) condição. Agora é ele que parece um escravo, com as roupas rasgadas e sem coroa.

${ }^{236}$ Barrier acrescenta após feras "fornecidas por Alexandre". Kaestli diz a mesma coisa em outras palavras, também acrescidas após feras: "que Alexandre deu para a caçada". Em ambos os casos a afirmação é a mesma: por fornecer os animais, Alexandre se posiciona como o patrocinador dos jogos, arcando com as custas do castigo infligido a Tecla.

${ }^{237}$ Sobre Trifrena cf. apêncice A, seção 27. Trifena (p. 128).
} 


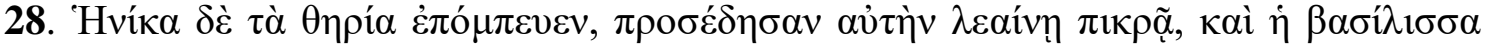

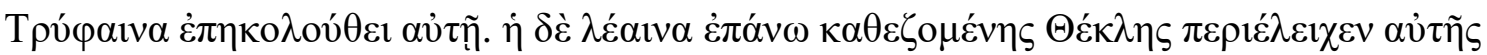

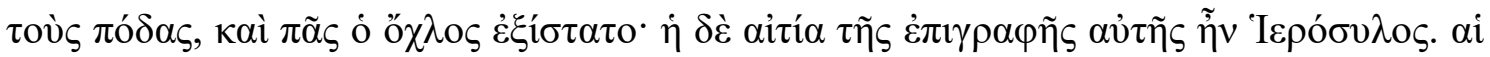

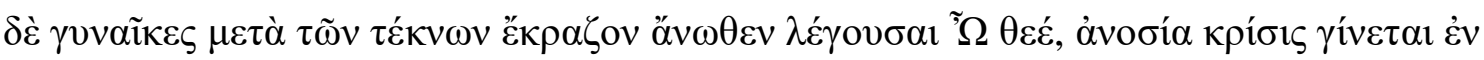

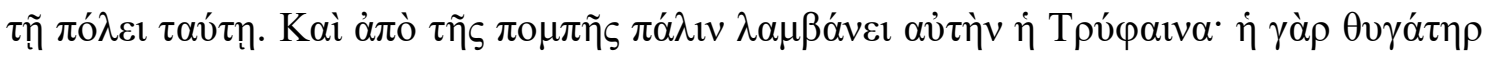

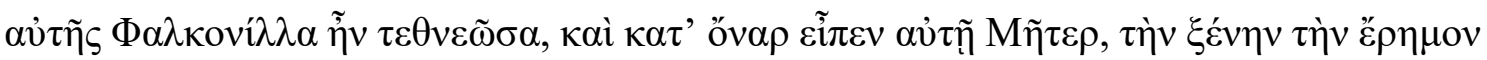

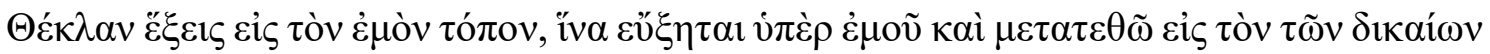

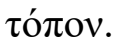

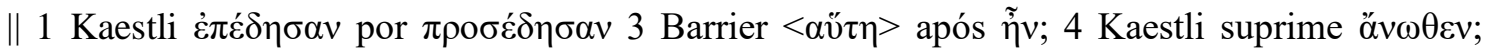

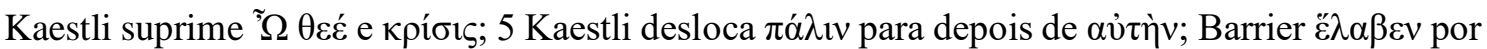

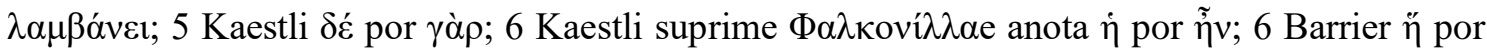

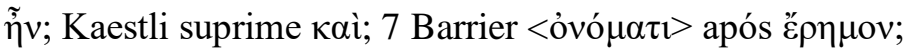

28. Enquanto as feras desfilavam, prenderam-na a uma leoa feroz, e a rainha Trifena a seguia de perto. Mas a leoa, acima da qual Tecla estava sentada, lambia-lhe os pés. ${ }^{238} \mathrm{E}$ toda a multidão ficou admirada. E a acusação contra ela, que constava na inscrição, ${ }^{239}$ era "Sacrílega". E as mulheres junto com os filhos gritavam de novo, dizendo: "Ó Deus, acontece um julgamento ímpio nesta cidade.” [E a Trifena tirou-a novamente do desfile, uma vez que Falconila, a filha dela que havia morrido, dissera-lhe em sonho: "Mãe, tenha Tecla, a estrangeira solitária, em meu lugar, para que ela ore por mim e eu seja transferida ao lugar dos justos.”] $]^{240}$

\footnotetext{
${ }^{238}$ Uma vesão latina, segundo Ramsay (1893, p. 400 e 401), diz que Tecla foi colocada em cima de uma jaula, dentro da qual ia a leoa e que esta lhe lambia os pés por entre as grades da jaula.

${ }^{239} \mathrm{O}$ motivo da condenação de Tecla possivelmente estava escrito em uma plaquinha, que ela portava durante o desfile.

${ }^{240}$ Pervo considera o trecho entre colchetes uma interpolação posterior, visível em traduções sírias e armênias (2014, p. 156).
} 


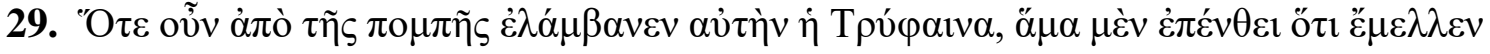

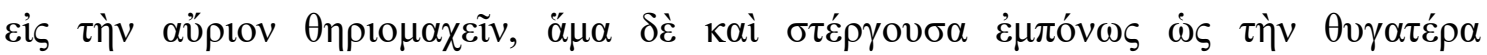

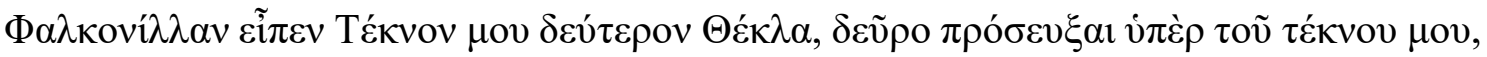

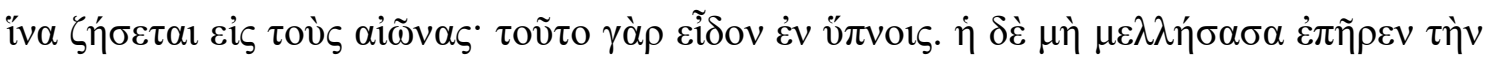

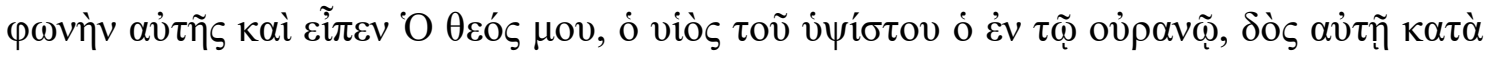

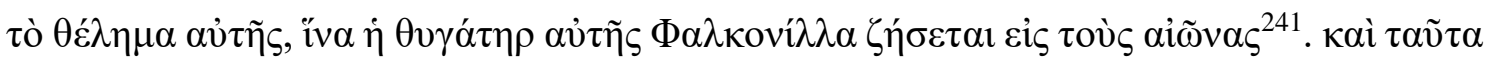

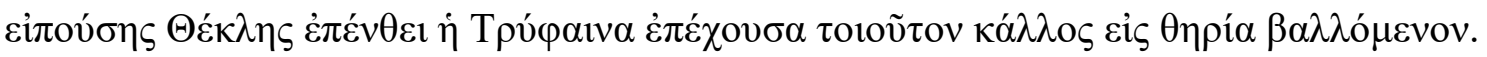

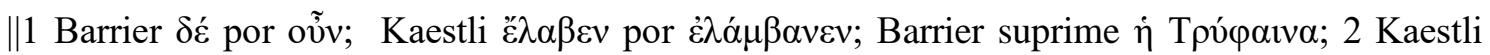

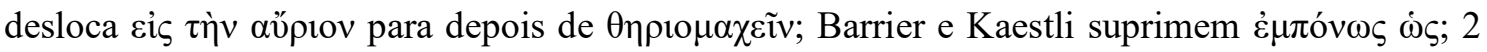

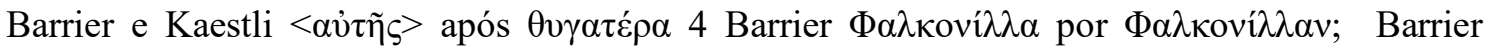

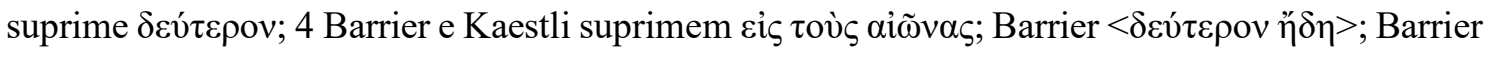

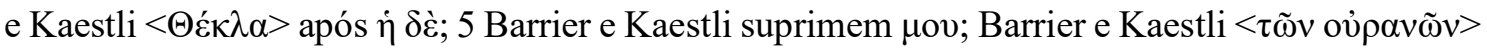

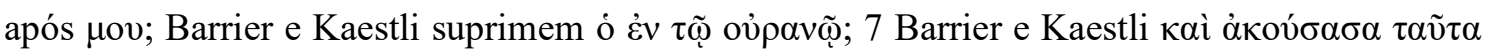

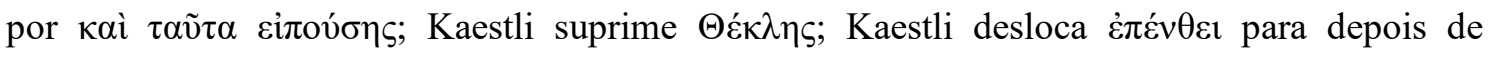

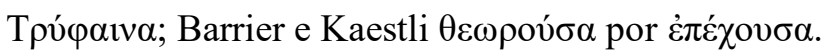

29. Quando Trifena retirou-a do desfile, chorava porque ela [Tecla] estava fadada a lutar com as feras na manhã seguinte e, ao mesmo tempo, sentindo intensa ${ }^{242}$ afeição ${ }^{243}$ como por sua filha Falconila, disse: "Minha segunda filha, Tecla, venha, ore por minha filha, para que ela viva pela eternidade. Pois eu vi isto em um sonho.” E ela, sem hesitar, ergueu a voz e disse: "Ó Deus meu, fillho do Altíssimo, que está no Céu, dá-lhe conforme o desejo dela, para que a filha dela, Falconila, viva para sempre."244 Depois que Tecla disse isso, Trifena continuou chorando por tal beleza ser lançada às feras.

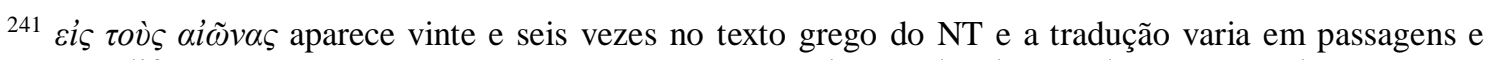
versões diferentes entre "eternamente", "para sempre", "pelos séculos dos séculos", "para todo o sempre".

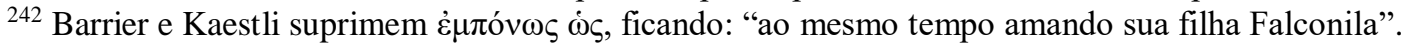

${ }^{243} \sigma \tau \varepsilon$ p $\gamma \omega$ também é amar. Portanto, outra opção aqui seria "amando-a intensamente" (o que permitiria usar um advérbio, como no texto grego). Eu usei afeição para ficar coerente com a tradução da seção 19 na qual, como aqui, procuro marcar a diferença de vocabulário no grego. Barrier (2008, p. 242), Sánchez (2013, p. 177) e Soares (2017, p. 65) traduzem por amor. Já Pervo (2014, p. 155), verte para "profunda afeição".

${ }^{244}$ Sánchez (2013, p.176), citando Patterson, entende que "este tipo de argumento que aparece em diferentes textos cristãos da época reflete a fusão entre as crenças judaico-cristãs da ressurreição e o conceito
} 


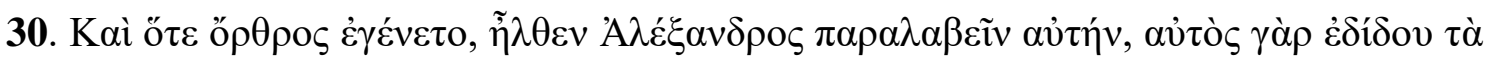

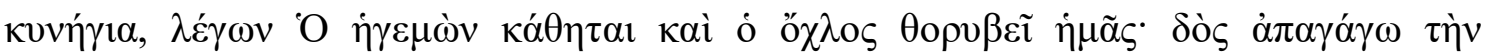

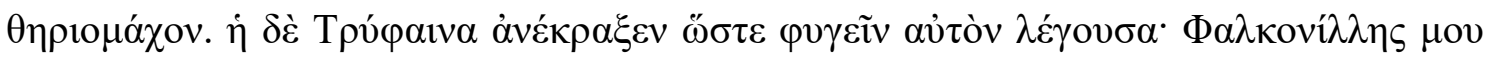

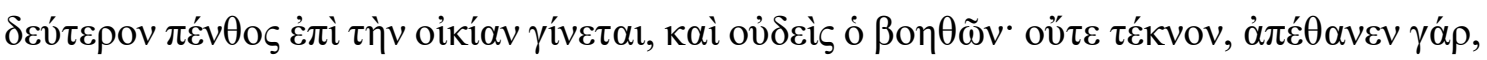

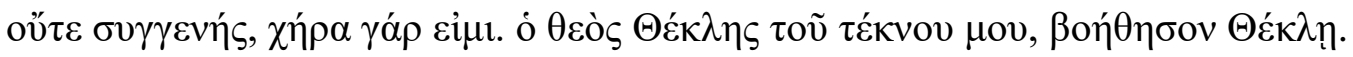

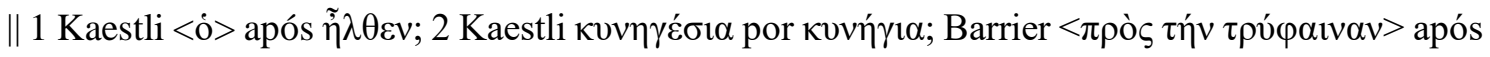

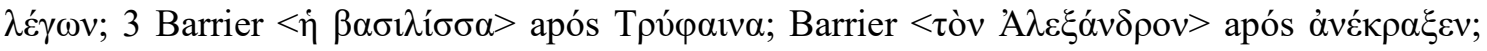

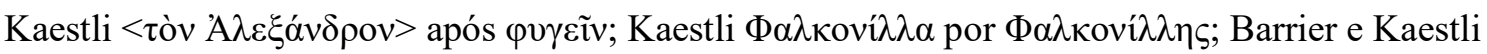

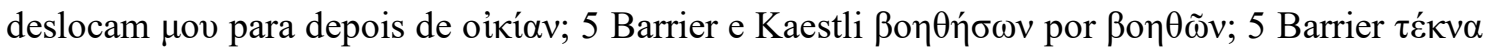

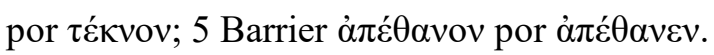

30. E quando a manhã chegou, Alexandre veio retomá-la, pois ele era o responsável pelos jogos com os animais, dizendo: “O governador está sentado e a multidão está alvoroçada por nós. Entregue [a moça] para que eu a conduza à batalha com as feras.” Mas Trifena gritou de modo a fazê-lo fugir, dizendo: "Um segundo luto por minha Falconila veio sobre a casa, e não há ninguém que ajude: nem filha, porque morreu, nem parente, pois sou viúva. Ó Deus de Tecla, minha filha, que Ele venha em socorro de Tecla!"

helenístico da imortalidade da alma que penetra fortemente o ideário cristão através do movimento neoplatônico". Bremmer (1996, p. 53) entende que esse trecho de APT, mostra a doutrina do purgatório em seus contornos iniciais. Para um resumo das ideias de Platão quanto à alma, cf. BURKET W. Religião grega na época clássica e arcaica. LOUREIRO M. J. S. (trad,). Lisboa: Fundação Calouste Gulbenkian, 1993. Para um estudo aprofundado sobre como o conceito de alma e vida após a morte no mundo grego, judaico e cristão mudaram sob a influência das ideias de Platão, cf. BREMMER, J. N. The rise and the fall of the afterlife. New Iork: Routledge, 2001. 


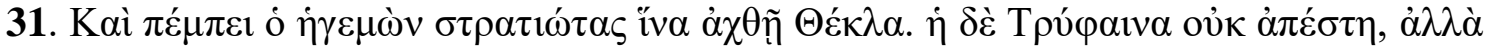

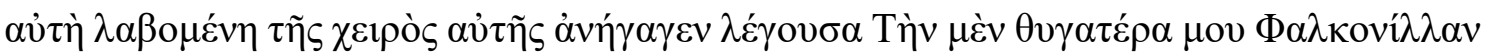

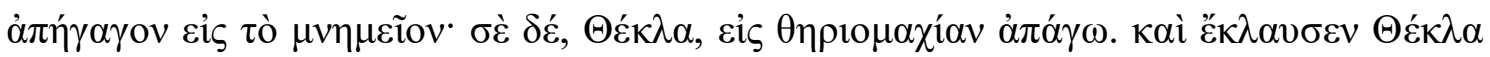

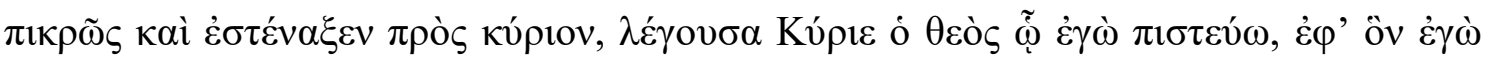

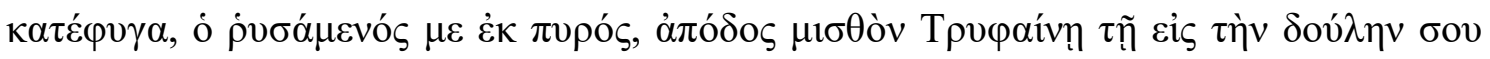

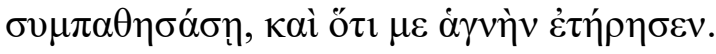

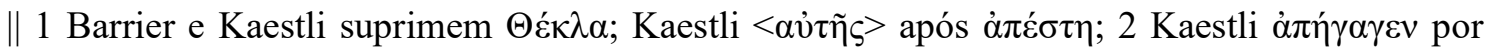

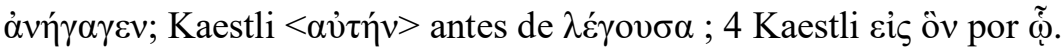

31. Mas o governador enviou soldados a fim de que Tecla fosse levada. E Trifena não se afastou, mas tomando-a pela mão, conduziu-a, dizendo: "Conduzi minha filha Falconila para a sepultura; e você, Tecla, conduzo para o combate com as feras." E Tecla chorou amargamente e lamentou para o Senhor, dizendo: "Senhor, Deus em quem eu creio, junto a quem eu me refugiei, aquele que me salvou do fogo, conceda uma recompensa para Trifena, que se compadeceu da sua serva e porque conservou-me casta."

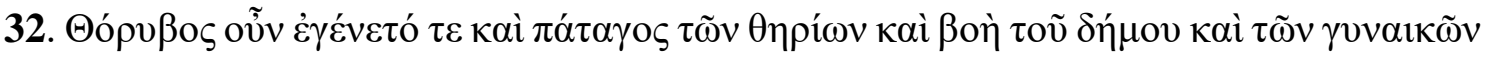

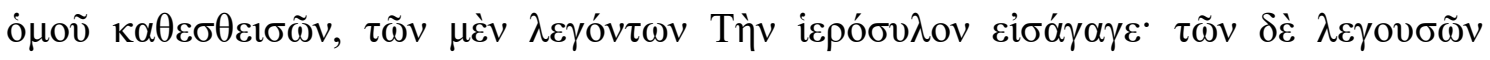

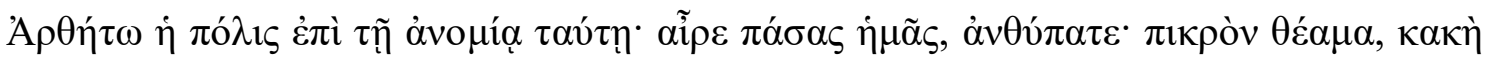
крíors.

32. Então, houve um alvoroço pelo bramido das feras e o grito do povo e das mulheres, que estavam sentadas juntas. Por um lado, os homens diziam: “Traga a sacrílega!”; por outro, as mulheres diziam: "Que a cidade sucumba por causa dessa violação da lei. Execute todas nós, Procônsul! Espetáculo amargo, sentença má!” 


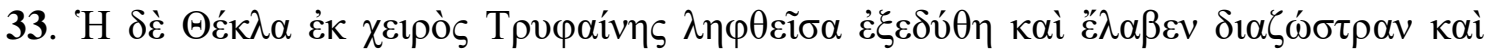

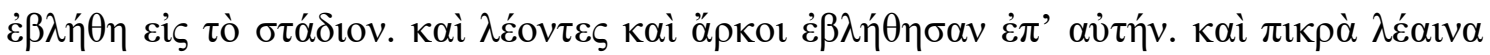

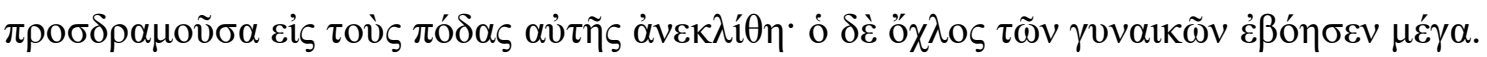

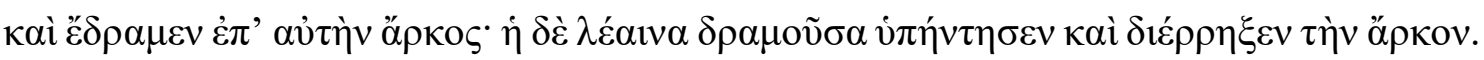

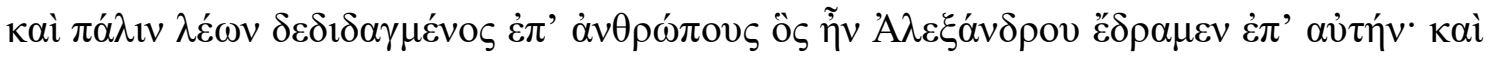

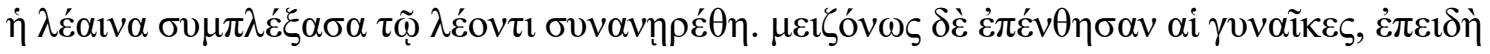

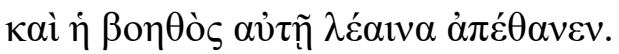

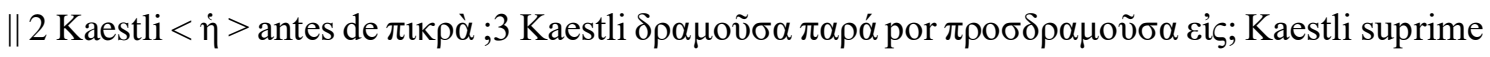

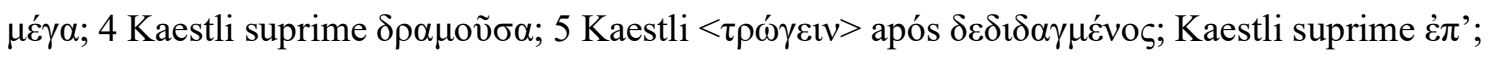

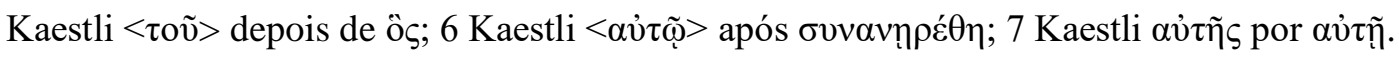

33. Após ser tomada da mão de Trifena, Tecla foi despida, recebeu um calção subligar ${ }^{245}$ e foi lançada no estádio. Então, leões e ursos foram lançados em direção a ela. Mas uma leoa feroz correu mais rápido e deitou-se a seus pés. E a multidão de mulheres deu grandes gritos. E uma ursa correu em direção a ela. Mas a leoa ${ }^{246}$, correndo, enfrentou e despedaçou a ursa. Por sua vez, um leão treinado para atacar homens, que pertencia a Alexandre, correu em direção a ela. Mas a leoa, bateu-se contra o leão e foi destruída junto com ele. As mulheres lamentaram muitíssimo, visto que a leoa, que era a defensora dela, também havia morrido.

\footnotetext{
${ }^{245}$ Barrier (2008, p. 256) traduz $\delta l \alpha \zeta \omega ́ \sigma \tau \rho \alpha v$ por "underpaints" (calção), Pervo (2014, p. 162), por "sash" (faixa)" e Sánchez (2013, p. 182) por "ceñidor" (cinta), assim como Soares (2017, p. 67). Segundo Aulete, subligar era uma faixa que, com certas amarrações e um cinto, se transformava numa espécie de calção e era usado, para ocultar os genitais dos lutadores (cf. em <http://www.aulete.com.br/subligar $>$, consultado em 30/08/2017). DGRA (p. 1076) explica que essa peça era usada pelos romanos também em sua prática de exercícios. Bremmer $(1996$, p. 53, 54) lembra que a nudez era uma forma usada pelos romanos para humilhar os criminosos condenados e adverte que, apesar de haver um componente sexual nesta cena, não se deve esquecer que os homens condenados também eram executados nus.

${ }^{246}$ A leoa que protege Tecla parece evocar o leão que ameaça Paulo no caminho a Damasco e é por ele batizado. Eles se reencontram na arena de feras em Éfeso e o animal se recusa a atacar o apóstolo após reconhecê-lo. Cf. AP, I e IX.
} 


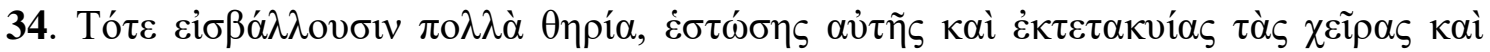

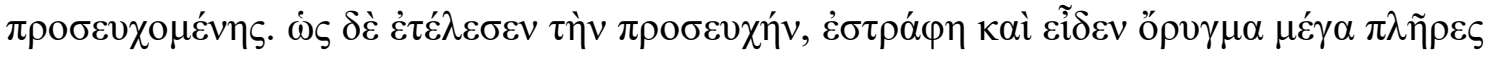

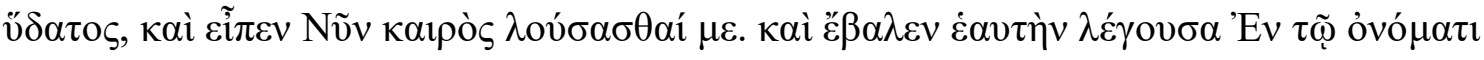

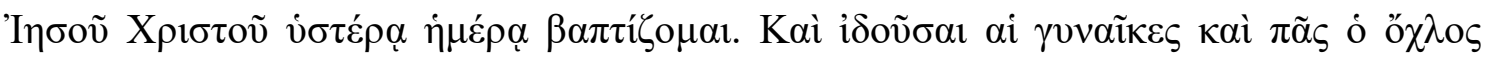

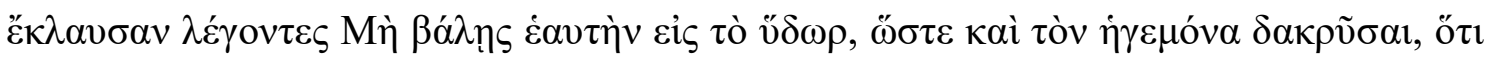

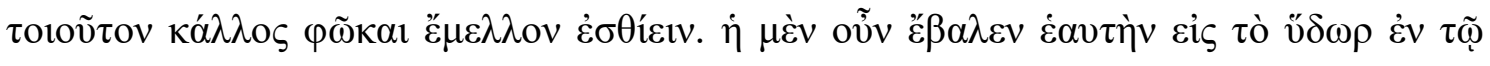

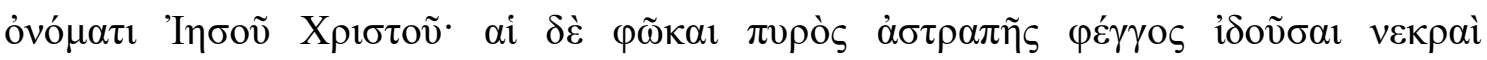

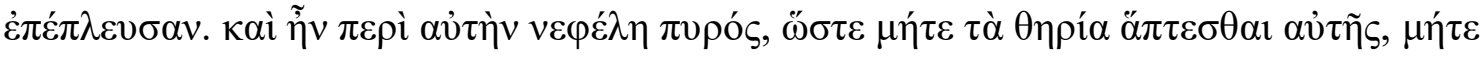

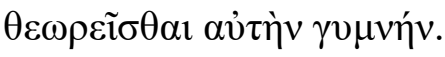

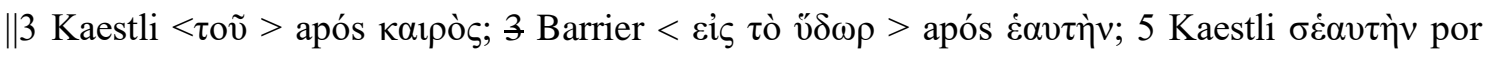

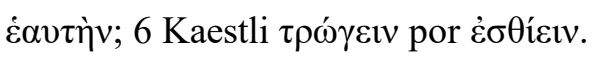

34. Então, introduziram muitas feras, enquanto ela permanecia em pé, com as mãos estendidas, orando. Quando terminou a oração, virou-se e viu um grande fosso cheio de água, e disse: "Agora é a oportunidade para eu me batizar." ${ }^{247}$ E lançou-se, dizendo: "Em nome de Jesus Cristo, eu me batizo em meu último dia!” Mas ao verem isso, as mulheres e toda a multidão, choraram, dizendo: "Não se lance na água!" De modo que até o governador verteu lágrimas, porque umas focas estavam prestes a devorar uma beleza tal. E ela, então, lançou-se na água em nome de Jesus Cristo, mas as focas, depois de ver o fulgor de um raio de fogo, boiaram mortas. E havia uma nuvem de fogo ao redor dela, de tal maneira que nem as feras podiam aproximar-se, nem sua nudez podia ser vista.

\footnotetext{
${ }^{247}$ No Novo Testamento $\lambda$ ov́ é batizar. Ao que parece, essa é a razão para Barrier traduzir o termo sempre por wash ou bath, mesmo que os léxicos indiquem o uso como batizar.
} 


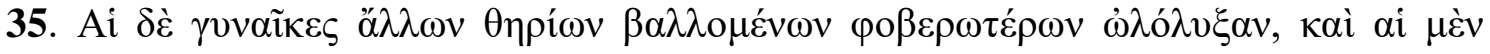

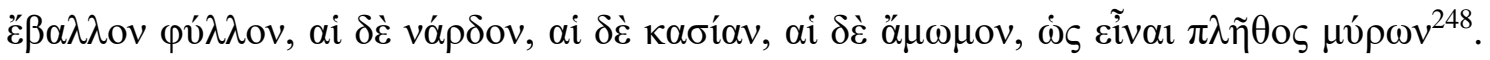

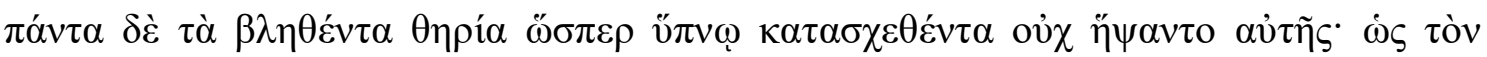

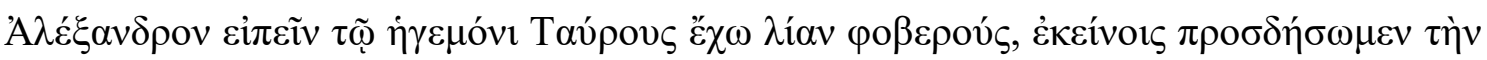

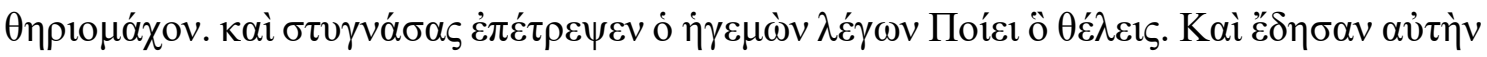

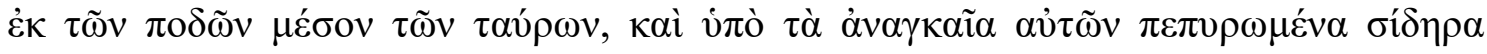

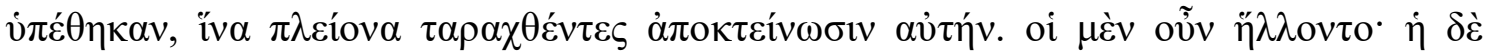
$\pi \varepsilon \rho 1 \kappa \alpha 10 \mu \varepsilon ́ v \eta \eta$

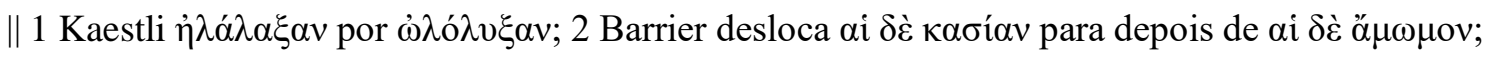

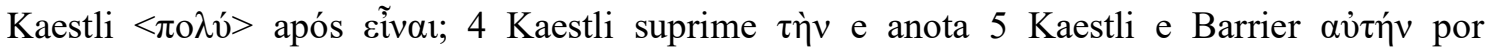

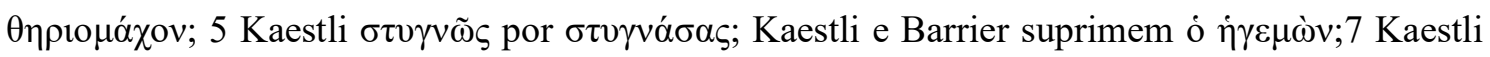

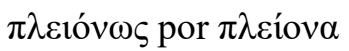

35. Mas, quando outras feras ainda mais apavorantes foram lançadas, as mulheres deram gritos agudos, e algumas lançaram pétalas, e outras, nardo, loureiro, ámono, para haver abundância de aromas. E todas as feras que haviam sido lançadas, como que tomadas pelo sono, não a tocaram, de sorte que Alexandre disse ao governador: "Eu tenho touros bem apavorantes, vamos prender a lutadora a eles." E, embora contrariado, o governador permitiu, dizendo: "Faça o que quiser." E prenderam-na pelos pés entre os touros. E colocaram ferros incandescentes sob os genitais deles, para que, agitando-se bem mais, eles a matassem. Então, eles saltaram. Mas a chama ardente consumiu as cordas e ela ficou como se [Tecla] não tivesse sido presa.

\footnotetext{
${ }^{248}$ Palavra de origem semítica traduzida no Novo Testamento por perfume, bálsamo, unguento.
} 


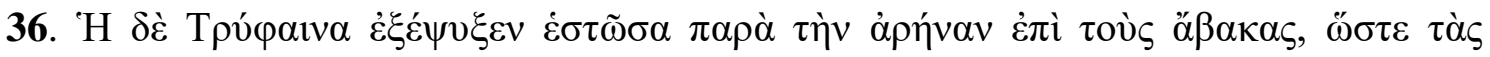

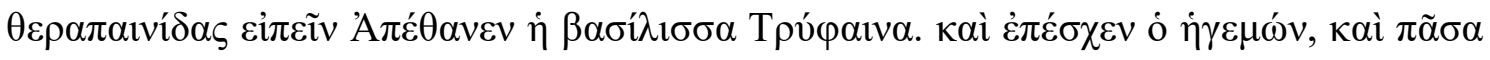

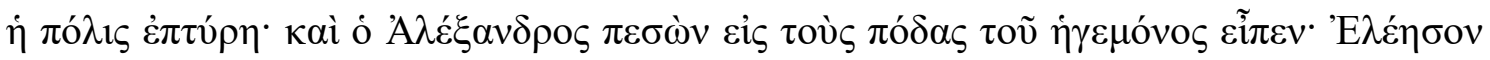

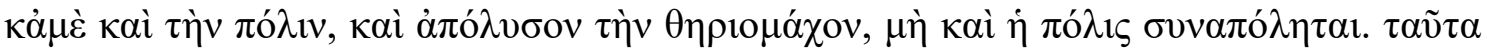

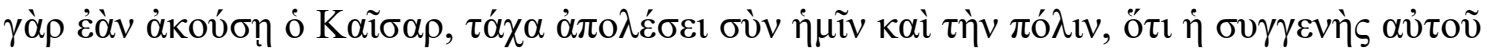

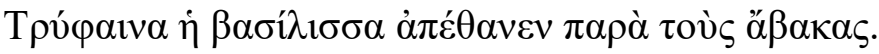

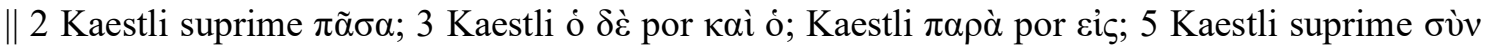

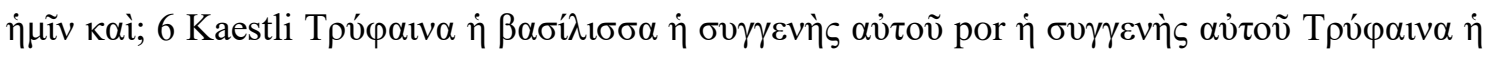
$\beta \alpha \sigma i ́ \lambda 1 \sigma \sigma \alpha$

36. E Trifena perdeu os sentidos estando em pé perto da arena, sobre a plataforma, ${ }^{249}$ de modo que as criadas disseram: “A rainha Trifena morreu!” E o governador imterrompeu [os jogos] e toda a cidade apavorou-se. Alexandre, lançando-se aos pés do governador, disse: "Tenha piedade de mim e da cidade. Liberte a lutadora ${ }^{250}$. Que a cidade não seja destruída junto com ela. Pois se o César ouvir estas coisas, prontamente nos destruirá junto com a cidade, porque a parente dele, a rainha Trifena, morreu junto à plataforma."

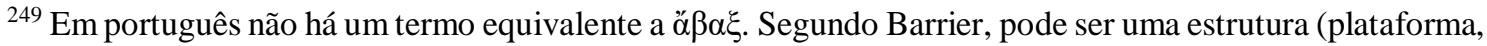
laje) de madeira ou mármore perto ou dentro do teatro, onde ficariam os lugares de honra da plateia. $\mathrm{O}$ $D G R A$, p. 2, 7, traz: "uma parte do teatro acima ou próximo do palco". Para entender a arquitetura e os usos de um anfiteatro romano cf. SMITH (1859, p. 82-90)

${ }^{250}$ Ao pé da letra: a que luta contra as feras. Sánchez (2013, p. 188) traduz por "a condenada"; Barrier (2008, p. 275) por "beastfighter"; Pervo por "condemned woman" e Soares (2017, p. 69) "liberte essa

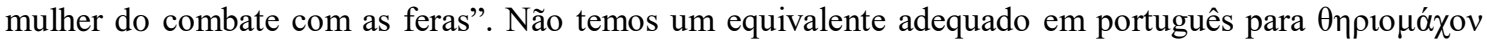
que, segundo $D G R A$, p. 202, refere-se a "pessoas que lutavam contra animais selvagens no circo. Eram pessoas que lutavam por dinheiro, e que tinham direito a usar armas, ou criminosos, que geralmente não recebiam permissão de ter meios de defesa contra os animais selvagens". Aqueles que lutavam com as feras por pagamento eram distintos dos gladiadores, os quais lutavam entre si.
} 


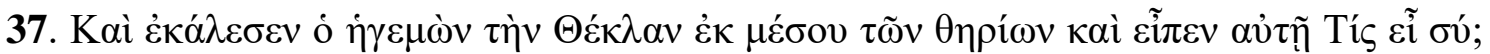

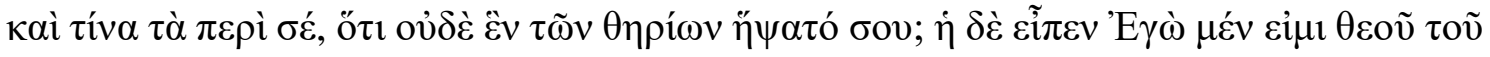

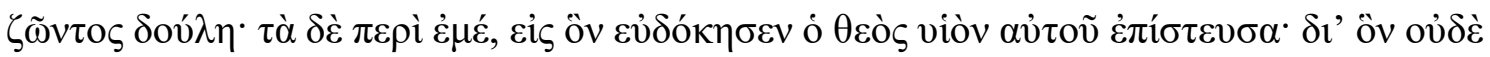

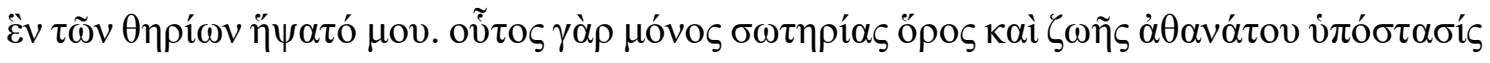

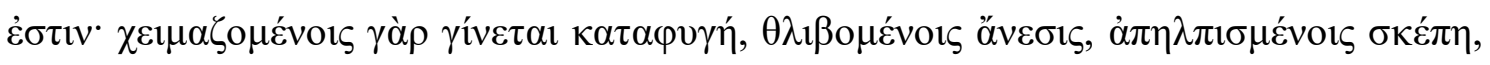

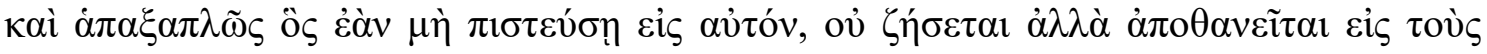
aĩ̃vas.

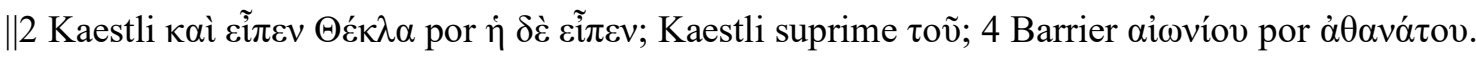

37. E o governador chamou Tecla de entre as feras e disse-lhe: "Quem é você? O que a cerca que nenhuma fera tocou em você?" E ela disse: "Eu sou uma serva do Deus vivo. Quanto ao que me cerca, eu cri naquele em quem Deus se agrada, o filho dele. Por isso nem uma das feras me tocou. Pois o mesmo é o único pilar de salvação e fundamento da vida imortal. É refúgio para quem está em meio à tempestade, um descanso para quem está sobrecarregado, proteção ao desesperado. Em resumo, quem não crer nele não viverá, mas morrerá para sempre”. 


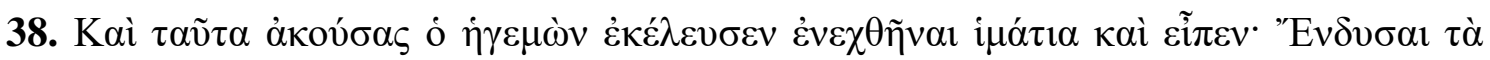

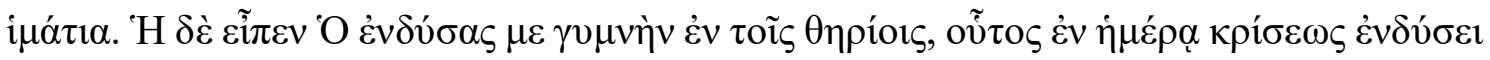

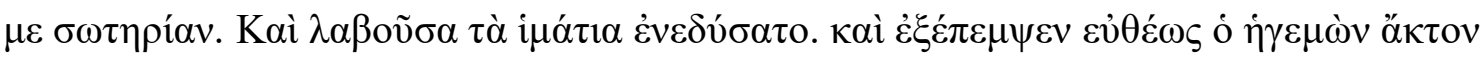

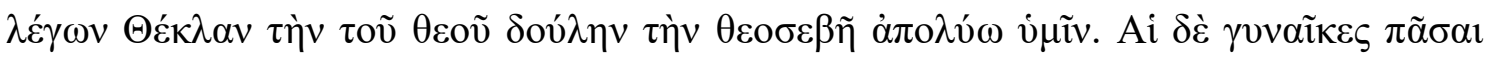

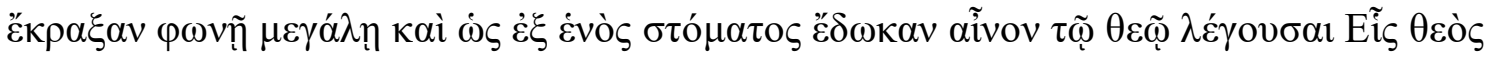

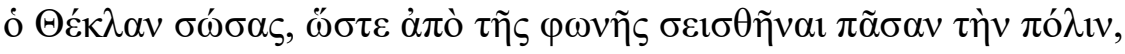

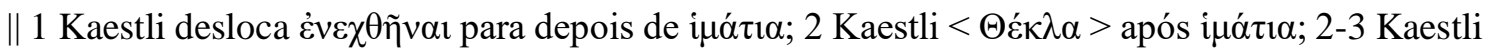

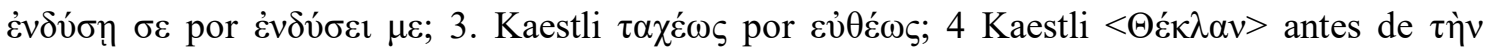

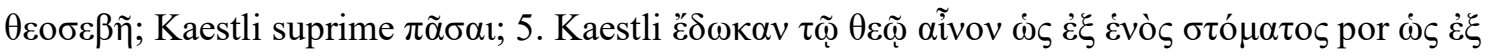

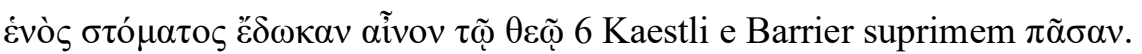

38. Depois de ouvir estas coisas, o governador ordenou que fossem trazidas vestimentas e disse: "Cubra-se com as vestimentas." E ela disse: “Aquele que me cobriu, estando nua entre as feras, esse me cobrirá com salvação no dia do julgamento.” E, pegando as vestimentas, cobriu-se. O governador imediatamente baixou uma resolução, ${ }^{251}$ dizendo: "Eu liberto Tecla, a piedosa serva de Deus, para vocês.” E todas as mulheres gritaram com grande voz e, como de uma única boca, deram louvor a Deus, dizendo: "Há um único ${ }^{252}$ Deus, o que salvou Tecla”, de tal forma que, por causa das vozes, toda a cidade foi sacudida.

\footnotetext{
${ }^{251}$ Barrier comenta que ǒktov vem do latim actio, algo como uma proposta política. Não há termo grego equivalente. As traduções de Barrier, Pervo e outros vão na mesma direção: o governador emitiu ou promulgou um decreto.

${ }^{252}$ Também: “O Deus que salvou Tecla é um”. Essa fala é uma declaração de fé em um único Deus.
} 


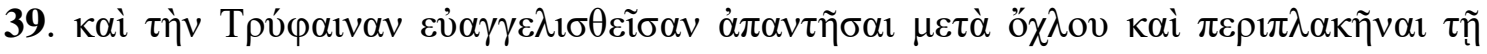

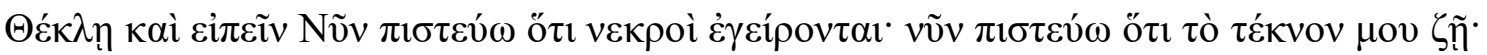

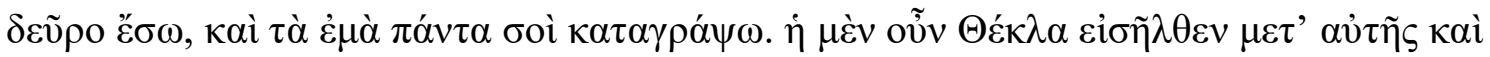

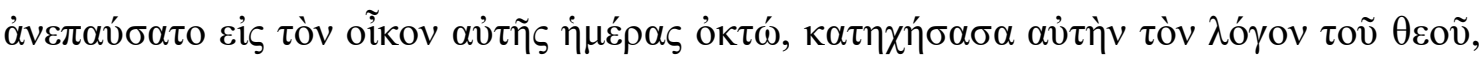

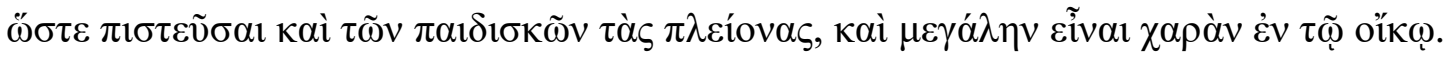

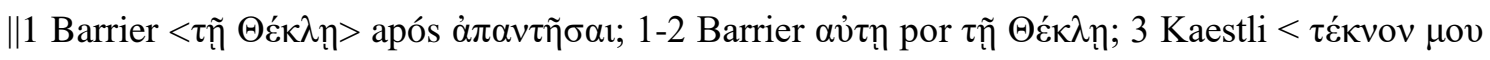

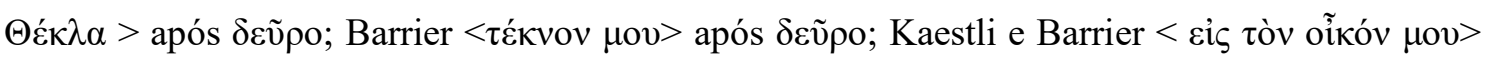

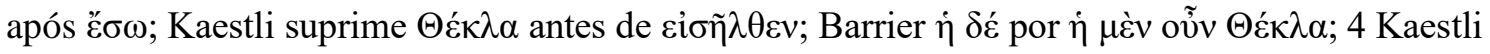

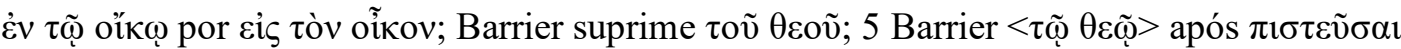

39. E Trifena, após receber a boa notícia, foi com a multidão ao encontro de Tecla e, abraçada por ela, disse: "Agora eu creio que os mortos ressuscitam. Agora eu creio que a minha filha vive. Venha aqui dentro, e eu vou transferir todos os meus bens para você." E então, Tecla entrou com ela e repousou em sua casa por oito dias, instruindo-a na palavra de Deus, de modo que também a maior parte das jovens escravas creu, e houve grande alegria na casa. 


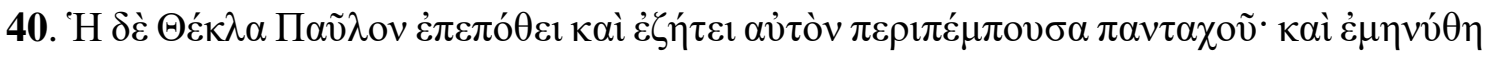

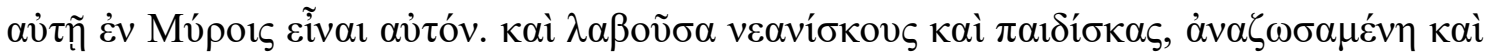

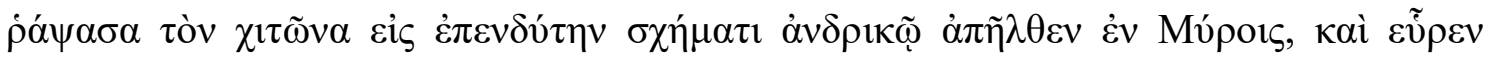

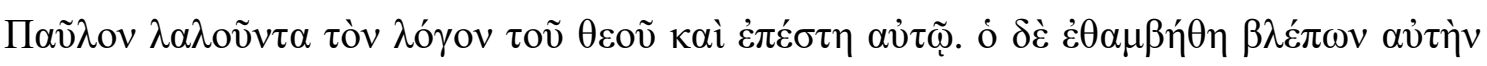

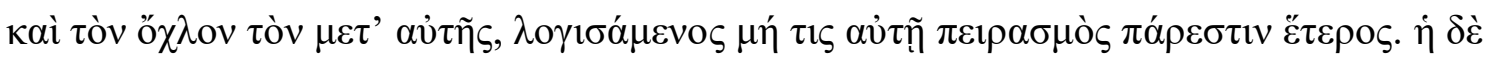

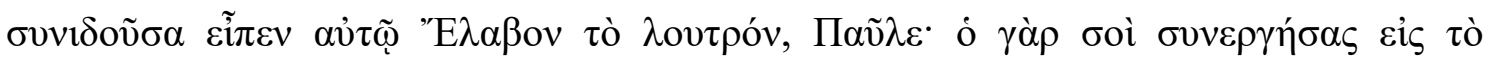

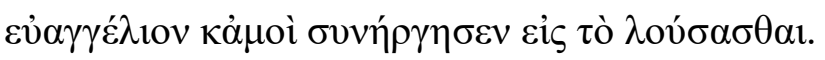

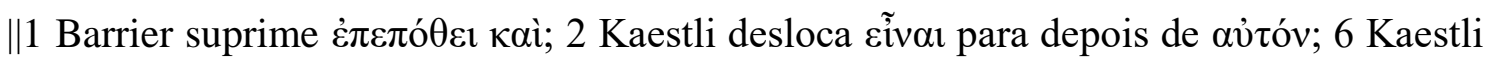
suprime $\alpha$ v่ $\tilde{\omega}$.

40. Mas Tecla sentia saudades de Paulo e o procurava enviando mensageiros por toda parte. E informaram-na que ele estava em Mira. E tendo tomado alguns servos e servas, após cingir-se de novo e ter costurado a túnica ao manto, ao feitio masculino, partiu para Mira e encontrou Paulo anunciando a Palavra de Deus. Então, ela apresentou-se diante dele. E ele espantou-se vendo-a e ao povo que estava com ela, cogitando se alguma outra provação estava sobrevindo a ela. Ela, compreendendo isto, disse-lhe: "Eu recebi o batismo, Paulo. Pois, quem coopera com você quanto ao evangelho também cooperou comigo quanto a ser batizada." 


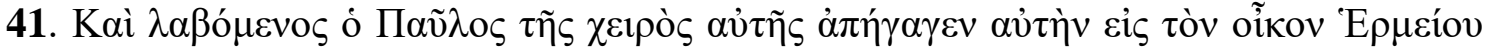

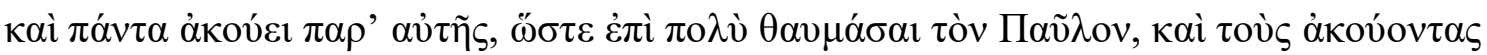

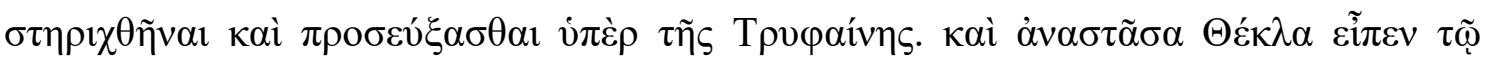

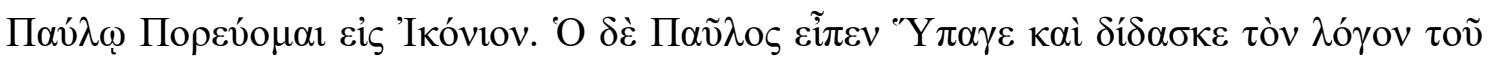

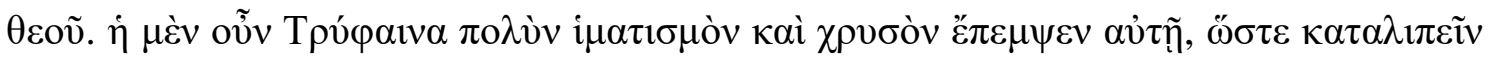

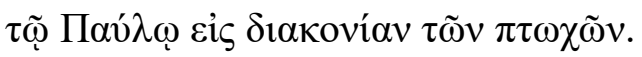

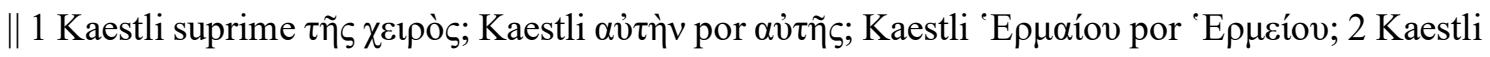

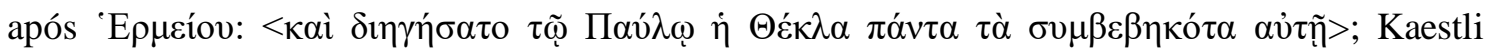

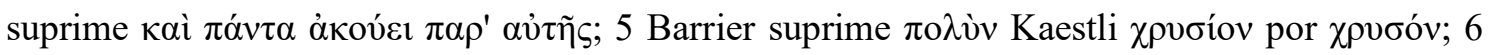

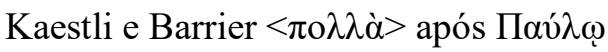

41. E Paulo, tendo tomado-a pela mão, conduziu-a para a casa de Hermeu e ouviu tudo dela, ao ponto de que Paulo ficou muito admirado, e os que ouviam foram fortalecidos e oraram por Trifena. E Tecla se levantou e disse a Paulo: "Eu vou para Icônio". E Paulo disse: "Vá e ensine a Palavra de Deus." E Trifena enviou com ela muitas vestes e riquezas, de sorte que as deixou a Paulo, para servir aos pobres.

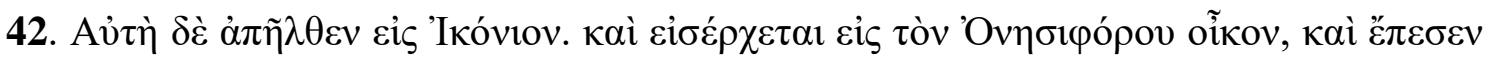

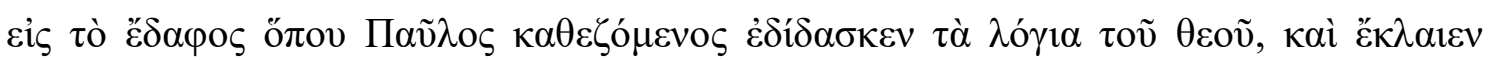

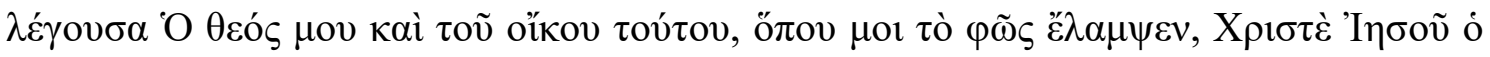

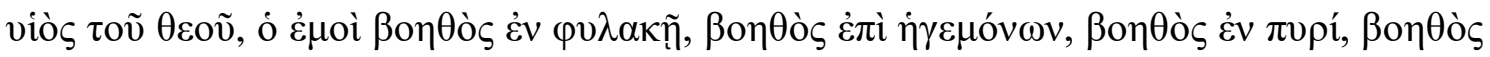

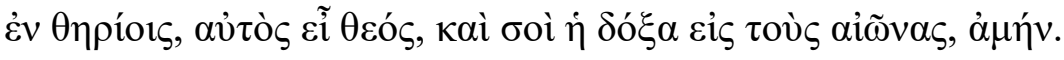

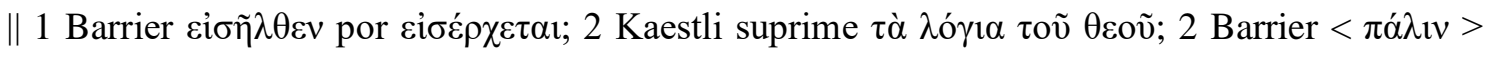

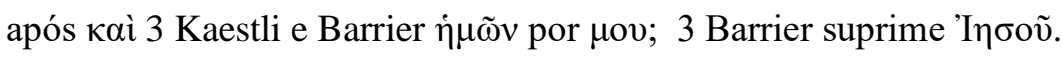

42. E ela partiu para Icônio. E entrou na casa de Onesíforo, e se lançou ao chão, no lugar onde Paulo, sentado, ensinava as palavras de Deus, e chorou, dizendo: “Ó Deus meu e também desta casa, onde a luz brilhou para mim, ó Jesus Cristo, o filho de Deus, o meu defensor na prisão, defensor diante dos governadores, defensor na fogueira, defensor diante das feras, tu mesmo és Deus, e a ti seja a glória para sempre, amém." 


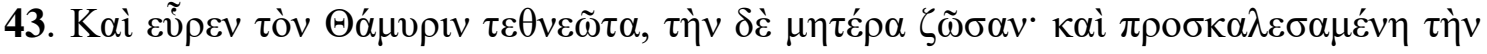

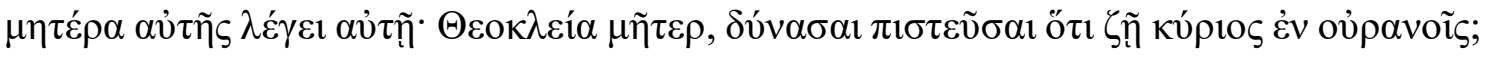

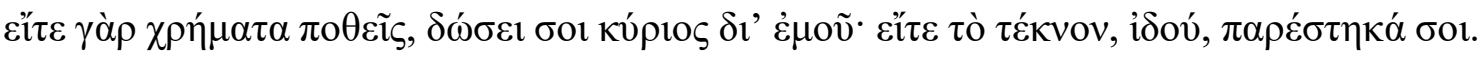

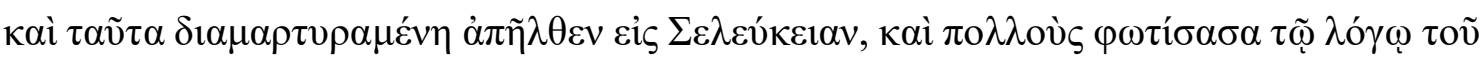

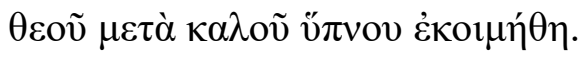

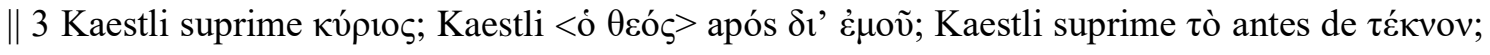
Kaestli suprime i $\delta o v ́$

43. E soube que Tamiris estava morto, mas a mãe dela estava viva. E, após convidar sua mãe, disse-lhe: “Teóclia, mãe, você pode acreditar que o Senhor vive no céu? Se deseja dinheiro, o Senhor lhe dará por meu intermédio; se a filha, veja, eu estou aqui a seu lado." ${ }^{253}$ Depois de dar testemunho disso, ela partiu para a Selêucia, e tendo iluminado a muitos com a Palavra de Deus, dormiu um belo sono.

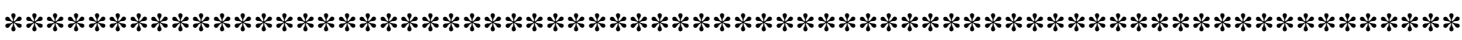

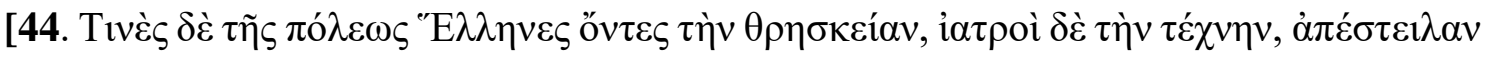

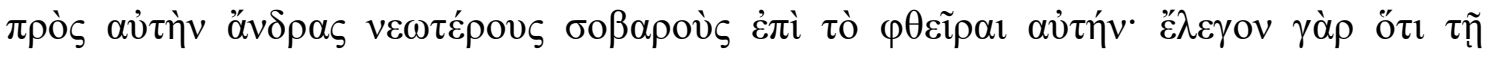

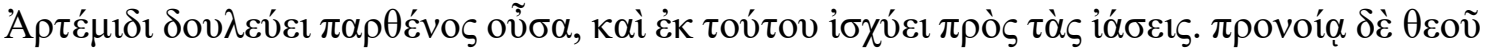

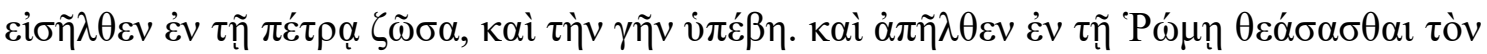

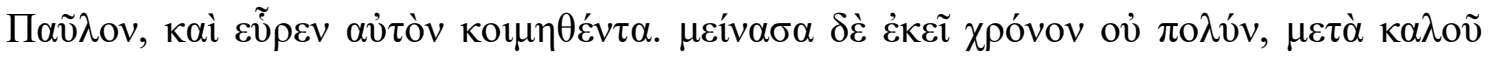

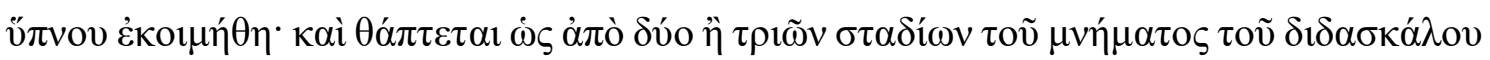

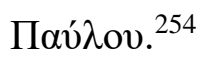

|| Kaestli não inclui 44; Barrier traz o texto grego, mas não traduz.

\footnotetext{
${ }^{253}$ Aqui, a fala respeitosa e amigável de Tecla contrasta bastante com o silêncio aparentemente rebelde dela em 7 e 8 e mostra que talvez ela tenha se calado, não para agradir, mas para evitar uma disputa verbal enquanto impunha sua vontade. Note-se que os papéis agora se invertem: Tecla fala e é sua mãe quem fica em silêncio.

${ }^{254}$ Parece haver um entendimento da parte dos editores que essas duas últimas seções do texto, 44 e 45 , devem-se a acréscimos bem posteriores ao restante, daí não estarem traduzidas por Barrier, nem incluídas na edição on progress de Kaestli. Lipsius as reproduz entre colchetes, ou seja, sugerindo a supressão. Também optei por não traduzir, mas reproduzo o texto grego de acordo com Lipsius. Sobre essas seções, cf. Soares (2017, p. 74).
} 


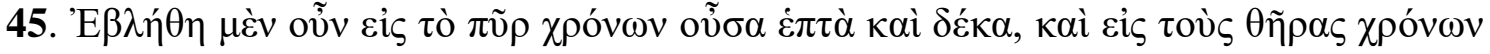

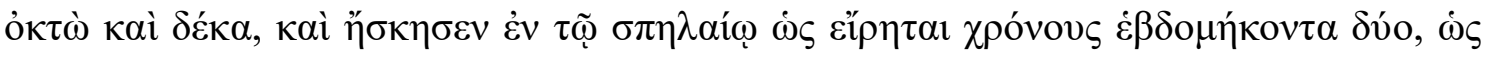

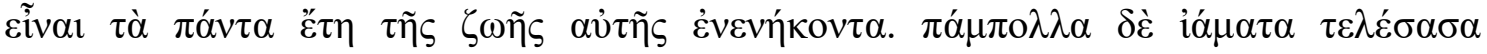

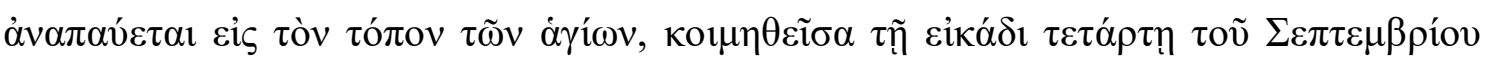

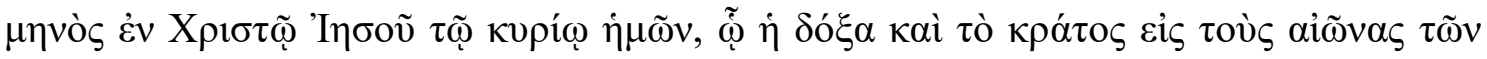

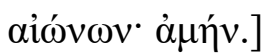

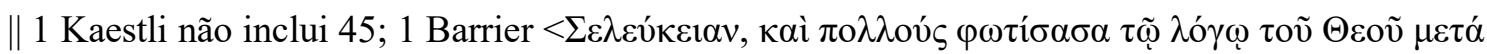

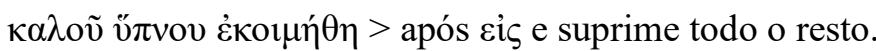




\section{REFERÊNCIAS BIBLIOGRÁFICAS}

\section{Texto fonte (edições e traduções):}

BARRIER, J. A critical introduction and commentary on the Acts of Paul and Thecla. Fort Worth, 2008. Disponível online em: <https://repository.tcu.edu/bitstream/handle/116099117/4041/barrier.pdf?sequen $\underline{\text { ce }=1 \& \text { isAllowed }=y}>$ Acesso em 11/01/2016.

KAESTLI, J.-D. (working in progress inédito, datado de 25/03/2016).

LIPSIUS, R. A. Acta Pauli e Theclae in Acta apostolorum apocrypha, v. 1. Leipzig: Mendelssohn, 1891, pp. 235-71. Disponível online em <https://archive.org/stream/actaapostolorvm01tiscgoog\#page/n354/mode/2up > e também em 〈http://www.patrologia-lib.ru/apocryph/novum/a_paul.htm>. Acesso em $11 / 01 / 2016$.

\section{Textos secundários:}

ARENDT, H. A vida do espírito. Rio de Janeiro: Relume dumará, 2000.

BAKHTIN, Mikhail. Questões de literatura e estética: a teoria do romance. São Paulo: Unesp, 1998.

BERGER, K. As formas literárias do Novo Testamento. São Paulo: Edições Loyola, 1998.

BÍBLIA. Português. Bíblia Sagrada. Tradução revista e corrigida de João Ferreira de Almeida. Barueri: Sociedade Bíblica do Brasil, 1969.

BÍBLIA. Português-inglês. Bíblia Sagrada. Nova Versão Internacional. São Paulo: Editora Vida, 2003.

BÍBLIA. Português. Bíblia Sagrada. Tradução Almeida Séculos 21.

BOWIE, E. Literary milieux. In Whitmarsh, T. (ed.) The Cambridge Companion to The Greek and Roman novel. Cambridge: Cambridge University Press, 2008, 17-38.

BRANDÃO, J. L. A invenção do Romance. Brasília: UNB, 2005. . Qual romance? (Entre antigos e modernos). in Eutomia. Revista de literatura e linguística, 12 (1), pp. 80-99, 2013. 
BREMMER, J. The apocryphal acts: authors, place, time and readership. in Bremmer, J. (ed.) The apocryphal acts of Thomas. Leuven: Peeters Publisher, 2001.

BREMMER, Jan N. Magic, Martyrdom and women's liberation in the Acts of Paul and Thecla. In: The apocryphal acts of Paul and Thecla. Studies on the Apocryphal Acts of the apostles 2, Kampen: Kok Pharos, 1996.

BRENER, Pedro Zanetta; MARTINS, Paulo. Novas luzes sobre a Segunda Sofística. CODEX -- Revista de Estudos Clássicos, [S.1.], v. 5, n. 2, p. 11-28, dez. 2017. Disponível em: $<$ https://revistas.ufrj.br/index.php/CODEX/article/view/12281/9856>. Acesso em: 11 Nov. 2018.

BURTON J.B. Byzantine readers. in Whitmarsh, T. (ed.) The Cambridge Companion to The Greek and Roman novel. Cambridge: Cambridge University Press, 2008, 272281.

CÁRITON. Quéreas e Calírroe. Tradução de Adriane S. Duarte. São Paulo: Editora 34, 2018 (no prelo).

DAVIS, S. J. The Cult of Saint Thecla: A Tradition of Women's Piety in Late Antiquity. New York: Oxford University Press, 2008.

DEL CERRO, G. (1992) “Cronología de los Hechos Apócrifos de los Apóstoles (AAA)”, AMal 15, 1-2, 85-96. In: AnMal eletrônica, número 10, 2001. <http://www.anmal.uma.es/numero10/cerro.htm > consultado em 05/08/2018).

DUARTE, A. S. Dez textos para conhecer o Romance Antigo. In: Faria, J. R. (ed.) Guia bibliográfico da FFLCH. São Paulo: 2016. Publicação online disponível em < https://www.fflch.usp.br/sites/fflch.usp.br/files/2017-11/Romance\%20antigo.pdf > (consultado em 06/01/2019).

DUNN, Peter W. The acts of Paul and the pauline legacy in the second century. 2006. 226 f. Dissertação (PHD) Universidade de Cambridge. Disponível online em < https://actapauli.files.wordpress.com/2009/01/pwdunn1996.pdf>. Acesso em $12 / 08 / 2018$.

EDSALL B. A. Hermogenes the Smith and Narrative Characterisation in The Acts of Paul: A Note on the Reception of 2 Timothy. In: New Testament Studies 64.1 (2018): 108-121.

ESOPO. Fábulas seguidas do Romance de Esopo. Tradução e apresentação por Malta, A. e Duarte, A. S. São Paulo: Editora 34, 2017. 
EUSÉBIO DE CESAREIA. História eclesiástica. Tradução de Wolfang Fisher. São Paulo: Editora Novo Século, 2002.

EURIPEDES. The Complete Greek Drama, edited by Whitney J. Oates and Eugene O'Neill, Jr. in two volumes. 2. Electra, translated by E. P. Coleridge. New York. Random House. 1938. Disponível online em < http://www.perseus.tufts.edu/hopper/text?doc=Perseus\%3Atext\%3A1999.01.009 6\%3Acard\%3D547> Acesso em 10/01/2019.

EYL, J. Why Thekla Does Not See Paul: Visual Perception and the Displacement of Erōs in the Acts of Paul and Thekla. In Perkins, J.; Pervo R.; Pinheiro M. P. F. (editores) The Ancient Novel and Early Christian and Jewish Narrative: Fictional Intersections. Groningen: Barkhuis Publishing \& Groningen University Library, 2012.

FUSILLO, M. Modernity and post-modernity. in Whitmarsh, T. (ed.) The Cambridge Companion to The Greek and Roman novel. Cambridge: Cambridge University Press, 2008, 331-339.

GOLDHILL, S. Genre. in Whitmarsh, T. (ed.) The Cambridge Companion to The Greek and Roman novel. Cambridge: Cambridge University Press, 2008, 185-200.

GOODSPEED, E. J. The Acts of Paul and Thecla. In: The Biblical World. V.17, p. 185190. University of Chicago Press: Chicado, 1901. Disponível em vários formatos em < https://archive.org/details/jstor-3136819 > consultado em 12/08/2018.

HÄGG, T. The new heroes: apostles, martyrs and saints: Paul and Thecla. in The novel in antiquity. Berkeley: University of California Press,1983, pp. 154-62.

HERÓDOTO. Histórias. GODLAY, A.D. (trad. Para o inglês). Cambridge: Harvard University, 1920. Disponível on line em 〈 http://www.perseus.tufts.edu $>$

HILHORST, A. Tertullian. In BREMMER, J. N. The Apocryphal Acts of Paul And Thecla. (2 ed.) Kampen: Kok Pharos Publishers, 1996.

HIRSCHBERGER, M. Marriages Spoiled: The Deconstruction of Novel Discourse in Early Christian Novel Narratives. In Perkins, J.; Pervo R.; Pinheiro M. P. F. (editores) The Ancient Novel and Early Christian and Jewish Narrative: Fictional Intersections. Groningen: Barkhuis Publishing \& Groningen University Library, 2012. 
HOCK, Ronald F.. The greek novel. In: AUNE, David E. (Ed.). Greco-Roman Literature and the New Testament: Selected Forms and Genres. Atlanta: Scholars Press, 1988. Cap. 7. p. 127-146. (21)..

HOLZBERG, Niklas. The Genre: Novels Proper and the Fringe. In: SCHMELING, G. (org.). The novel in the ancient world. Boston-Leiden: Brill Academic Publishers, 2003.

HOMERO. Ilíada. Trad. de Frederico Lourenço. São Paulo: Penguin Companhia das Letras, 2013.

IPIRANGA JR., P. A concepção de pathos em relatos híbridos na antiguidade: José e Aseneth e Os atos de Paulo e Tecla. In Classica, 26/2, 65-84, 2013 (online em http://revista.classica.org.br/classica/article/view/263/224).

. O romance antigo: teorização e crítica. in Eutomia. Revista de literatura e linguística, $14 \quad$ (1), pp. 60-91, 2014. Disponível em https://periodicos.ufpe.br/revistas/EUTOMIA/article/view/726/550

IRINEU. Adversus Haereses. Disponível em http://www.newadvent.org/fathers/0103128.htm> Acesso em 02 de novembro de 2016.

JACOBS, A. S. A Family Affair: Marriage, Class, and Ethics in the Apocryphal Acts of the Apostles. In: Journal of Early Christian Studies. Johns Hopkins University Press: Spring, 1999. Volume 7, Número 1, pp. 105-138. Disponível em < https://hcommons.org/deposits/item/hc:10743/ > consultado em 07/08/2018.

JOHNSON, Scott Fitzgerald. Christian Apocrypha. In: RICHTER, Daniel S. e JOHNSON, William. The Oxford Handbook to the Second Sophistic. Oxford. Oxford University Press: 2017. Disponível em < http://www.oxfordhandbooks.com> Acesso em 01/05/2018.

KRISTENSEN, T. (2016). Landscape, Space, and Presence in the Cult of Thekla at Meriamlik. Journal of Early Christian Studies, 24(2), 229-263.

LE BLANT, E. Les Actes des martyrs. Supplément aux Acta sincera de Dom Ruinart. In: Mémoires de l'Institut de France. Tomo 30, $2^{\mathrm{a}}$ parte, p. 57-347, 1883. Disponível em < https://www.persee.fr/doc/minf_0398-3609_1883_num_30_2_987 > Acesso em 30/01/2019.

LONGO. Dáfnis e Cloé. Denise Bottman (trad.). Campinas: Pontes, 1990. 
MORALES H. "Challenging some orthodoxies: the politics of genre and the ancient Greek novel”. In: KARLA, G., 2009, p.1-12

MORGAN, J. Intertextuality. The Cambridge Companion to The Greek and Roman novel. Cambridge: Cambridge University Press, 2008, 218-227.

MUSURILLO, H. The Acts of the Christian Martyrs. Oxford: At the Clarendon Press, 1972.

NOGUEIRA, P. A. de S. Atos Apostólicos Apócrifos e a religiosidade popular do Mediterrâneo. In: Revista de Interpretação Bíblica Latino-Americana (RIBLA), no 73, 2016. Disponível em < https://bit.ly/2NZq63t>, acesso em 31/07/18.

PAROSCHI, W. Origem e transmissão do texto do Novo Testamento. Barueri, SP: Sociedade Bíblica do Brasil, 2012.

PERKINS, J. (ed) Ancient fiction and early christian narrative. 1998

PERVO, R. The Acts of Paulo. A new translation and commentary. Eugene: Cascade Books, 2014.

The ancient novel becomes Christian. In Schmeling, G. (ed) The novel in the ancient world. Leiden: Brill, 1996, pp. 685-711.

"Introduction." In: The Ancient Novel and Early Christian and Jewish Narrative: Fictional Intersections, edited by Pinheiro Marília P. Futre, Perkins Judith, and Pervo Richard, XV-XX. Barkhuis, 2012. http://www.jstor.org/stable/j.ctt13wwxr7.5.

PORTER, S.E. Early apocryphal non-gospel literature and the new testament text. JGRChJ 8, p. 192-8, 2011-12.

RAMSAY, W.M. The Church in the Roman Empire Before A.D. 170. New York \& London, 1893, p. 390-391.

St. Paul: the Traveller and the Roman Citizen. New York: G. P. Putnam's Sons; Londres: Hodder \& Stoughton, 1898.

RANCE, Philip. "Win but not overwin" - The history of a proverb form the sententiae Menandri and a classical allusion in Sr. Paul1s epistle to the romans. In: Philologie, 152.2, 2008. Disponível online em < www.academia.edu $>$ Acesso em $13 / 01 / 2019$.

RORDORF, William. Tradition and Composition in the Acts of Thecla. The State of Question. Semeia 38, 43-52. Decartur, GA. Scholar Press, 1986.

RUIZ-MONTERO, Consuelo. The Rise of the Greek Novel. In: SCHMELING, G. (org.). The novel in the ancient world. Boston-Leiden: Brill Academic Publishers, 2003. 
SÁNCHEZ, Ángel Narro. Orígenes y desarrollo de la hagiografía griega a través de la figura de santa Tecla. Tese de doutorado. Valência, 2013.

SANO, L. História e ficção no romance grego e o caso de Siracusa em Quéreas e Calírroe, de Cáriton de Afrodísias. in Eutomia. Revista de literatura e linguística, 15 (1), 2015, pp. 60-91,

. Prazer e utilidade na leitura do romance grego. In de Brose, R. e outros (org.) Oralidade, escrita e performance na Antiguidade. Fortaleza: Expressão Gráfica Editora, 2013a, pp. 106-124.

SANTOS, Samuel Nunes dos. Identidade cristã no século II d.C: uma análise da I Apologia de Justino Mártir. Dissertação para obtenção do grau Mestre em História apresentada ao PPG em História da UFG. Disponível online em < pos.historia.ufg.br >. Acesso em 28/10/2018.

SEBASTIANI, B. B. Políbio. In: Maurício Parada. (org.). In Os historiadores: clássicos da história. Volume 1. 1ed. Rio de Janeiro: PUC-RJ, Vozes, 2012, p. 51- 67.

SCHENEEMELCHER, W. (ed.). New Testament Apocrypha. Lousville: Westminster John Knox Press, 2003.

SILVA, Maria de F. A fortuna de um autor chamado Menandro. In: Revista portuguesa de história do livro e da edição. Ano XII, nº 24 - 2009.

SMITH, W (ed.). A dictionary of greek and roman antiquities. Boston: Little, Brown, and Company, 1859.

SOARES, C. da C. Atos de Paulo e Tecla. A narrativa romanesca e o discurso sobre a imagem do apóstolo. São Paulo: Fonte editorial, 2017.

SOARES, M. T. M. Ekphasis e enargeia na historiografia de Tucídides e no pensamento filosófico de Paul Ricouer. Talia dixit, Extremadura, v. 6, p. 1-23, 2001.

STOWERS, Stanley K. The Diatribe. In: AUNE, David Edward (Editor). Greco-Roman Literature and the New Testament: selected forms and genres. SBL $\mathrm{n}^{\circ} 21$. Atlanta, Georgia: Scholars Press, 1988.

TÁCITO. The annals. CHURCH, Alfred John; BRODRIBB, William Jackson (trad.). Disponível em < http://www.perseus.tufts.edu $>$. Consultado em 12/11/18.

TERTUliAnO. De baptismo. XVII. In: THELWALL, S. (trad.). Ante-Nicene Christian Library. Edinburg: T. \& T. Clark, 1869. (Disponível on-line em <http://www.tertullian.org/anf/anf03/anf03-49.htm\#P11466_3245563>, acesso em 23/11/2018. 
Apologia. IX. VIDAL, J. F; PASQUOTTO, Luiz F. Karps (trads.). Disponível em < http://www.tertullian.org/brazilian/apologia.html $>$. Acesso em 23/11/2018.

De Oratio. XVII. In: EVANS, E. (ed.). Tertullian's Tract on the Prayer. 1953. em http://www.tertullian.org/articles/evans_orat/evans_orat_04english.htm $>$ Acesso em 30/01/2019.

TUCÍDIDES. História da Guerra do Peloponeso. Tradução de Raul M. Rosado Fernandes e M. Grabriela P. Branwehr: Funcação Caouste Gulbenkian, s.d.

VIELHAUER, Philipp. História da literatura cristã primitiva: Introdução ao Novo Testamento, aos Apócrifos e aos Pais Apostólicos. Santo André: Academia Cristã, 2005.

WHITMARSH, T. Introdução. The Cambridge Companion to The Greek and Roman novel. Cambridge: Cambridge University Press, 2008, 1-14.

WHITE, J. L. Ancient Greek letters. In: AUNE, David E. (ed.). Greco-Roman literature and the New Testament. Sources for biblical studies, $\mathrm{n}^{\circ} .21$. Atlanta: Scholars Press, 1987, p.

ZAMFIR, Korinna. The Acts of Paul and Thecla Ecclesial, Social and Political Context. In: Ephemerides Theologicae Lovanienses, 92/3, 2016, p. 355-380. Disponível online em < $\underline{\text { www.academia.edu }}>$. Acesso em 15/11/2018.

\section{Dicionários:}

GINGRICH, F. Wilbur. Léxico do Novo Testamento Grego/português. São Paulo: Edições Vida Nova, 1983.

LIDELL, H. G.; SCOTT, R.; STUART-JONES, H. The Online Liddell-Scott-Jones Greek-English Lexicon. 2019.2 Disponível em: <http://stephanus.tlg.uci.edu/lsj/\#eid=1\&context=lsj>. Acesso em: 31 jan. 2019.

LOUW, Johannes; NIDA, Eugene. Léxico Grego-Português do Novo Testamento: baseado em domínios semânticos. Barueri: Sociedade Bíblica do Brasil, 2013.

MALHADAS, Daisi; DEZZOTI, Maria Celeste Consolin; NEVES, Maria Helena de Moura (Org.). Dicionário grego-português. Cotia: Ateliê Editorial, 2006.

SMITH, William (Ed.). Dictionary of Greek and Roman Antiquities. 2. ed. Boston: Little, Brown, And Company, 1859. 


\section{Apêndice A}

\section{$\underline{\text { Seção } 1}$}

Estava subindo. Sigo a opção de Barrier para anabaínontos. Ele alega que em Atos essa palavra com eis é usada no sentido de entrar em algum lugar ou subir a algum lugar, como um templo ou uma cidade (At. $2.24 ; 10.4 ; 11.2$ ). Na época de Paulo existiam duas importantes cidades com o nome de Antioquia e que são mencionadas no livro de Atos. Antioquia da Síria era uma cidade costeira enquanto Antioquia da Psídia ficava no mesmo planalto de Icônio. Se o autor de $A P T$ está aludindo a Atos 13.14, 49-51, que menciona a fuga de Paulo e Barnabé de Antioquia da Psídia para Icônio, então podemos supor que ele se refere à cidade na fronteira com a Frígia e não à que ficava às margens do Orontes, na Síria. No entanto, se o verbo anabaínonto está usado corretamente, e se a informação de que Alexandre é um siriarca (seção 26) procede, a cidade da qual Paulo foge é Antioquia da Síria e é para ela que ele volta depois, acompanhado de Tecla. No entanto, há controvérsias. Sanchez (2013) entende que a menção dessas duas cidades identifica $A P T$ logo de início com o livro de Atos. ${ }^{255}$ Mas não demora a admitir que o texto não permite identificar a qual Antioquia ele se refere. Dunn (2006, p. 22) considera mais provável que $A P T$ esteja falando de Antioquia da Pisídia. Basílio de Selêucia (que escreveu uma história de Tecla no século V), citado por Ramsay (1893, p. 390), afirma que a cidade de onde Paulo vem é Antioquia da Síria. Pervo tende a concordar e se apoia no testemunho de Nicetas e de Atos de Tito, no entanto reconhece que os dados fornecidos por Nicetas “não se encaixam confortavelmente nos fragmentos sobreviventes” (2014, p. 83). Para Barrier há duas opções: ou o autor estava falando de Antioquia da Síria (o que justifica o uso de "subindo") ou ele não é "confiável em tais pequenos detalhes" (2008, p. 101). Já Schneemelcher ameniza: não se deve esperar muita precisão do autor, que parece estar mais interessado em edificar a comunidade cristã e propagar uma imagem de Paulo do que em oferecer informações históricas e geográficas precisas. E, como o teólogo alemão bem observa, "a questão de qual Antioquia se fala aqui não admite uma resposta definitiva" (2003, p. 220).

\footnotetext{
255 A meu ver, este procedimento não é gratuito, mas indica uma estratégia de aproximação, senão com a obra de Lucas, pelo menos com alguma tradição oral bastante conhecida.
} 


\section{Possíveis trajetos para as viagens de Paulo e de Tecla}

Como o autor dos APT não é preciso ao se referir a Antioquia, podemos conjecturar várias propostas de trajeto para o apóstolo e sua discípula.

\section{Opção 1}

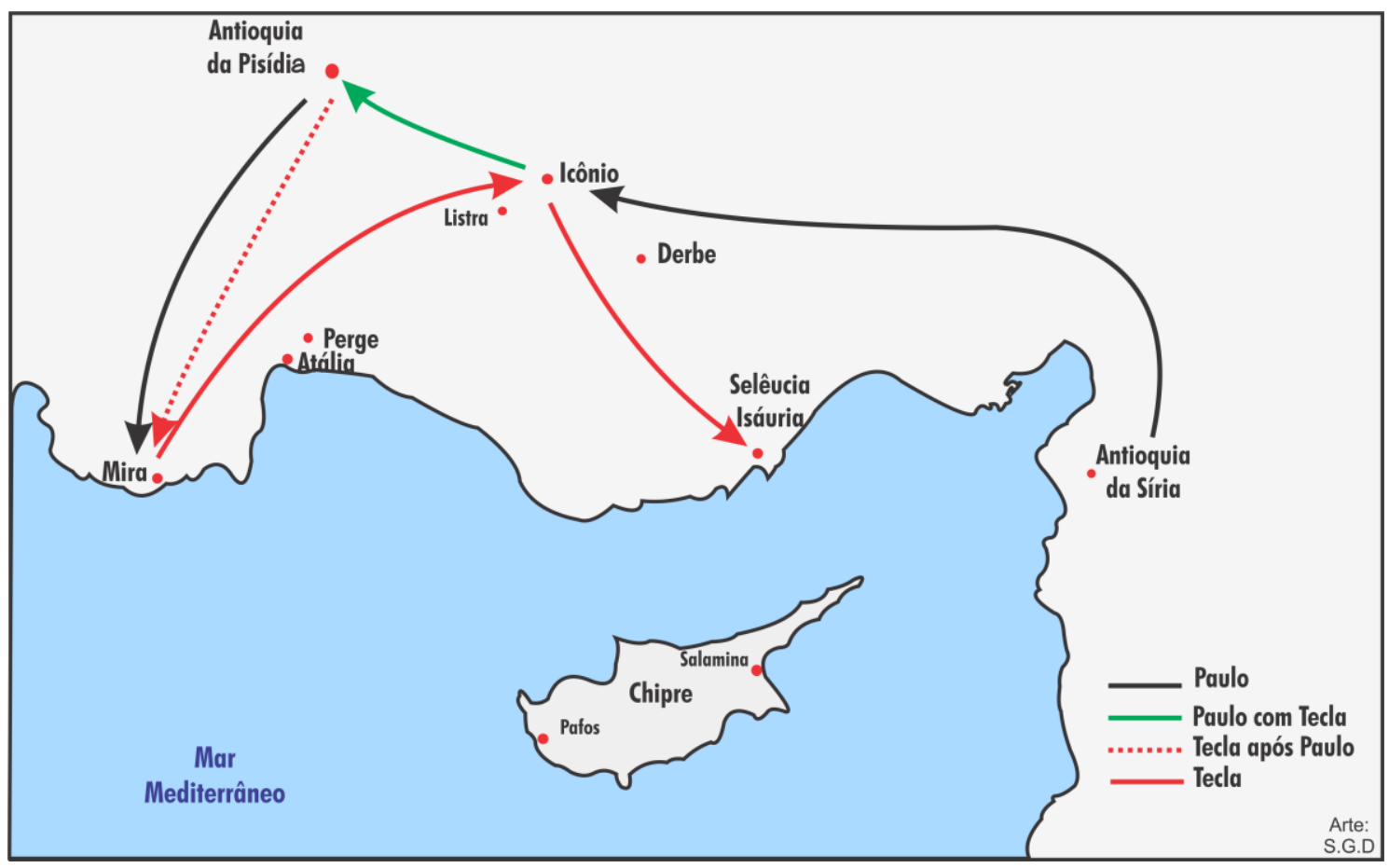

Paulo foge de Antioquia da Síria para Icônio. De lá parte para Antioquia da Pisídia, acompanhado de Tecla. Ele desaparece quando Alexandre assedia a jovem e é encontrado por ela, dias depois, em Mira, de onde ela se dirige a Icônio e, depois, a Selêucia.

Essa hipótese é coerente com o verbo que inicia o texto, anabaínonto já que Paulo parte de uma cidade costeira, a nível do mar, portanto, para uma cidade em maior altitude. Também se harmoniza com a designação de Alexandre como siriarca (caso ela esteja correta), uma posição elevada na sociedade se relacionaria a Antioquia da Síria e não à da Pisídia.

Contra ela está o fato de que a Estrada Real, citada na seção 3, ligava Icônio a Antioquia da Pisídia e não a Antioquia da Síria ${ }^{256}$.

256 "Não havia estrada real ligando Antioquia da Síria a Icônio nos primeiros dois séculos” (PERVO, 2013, p. 90) 


\section{Opção 2}

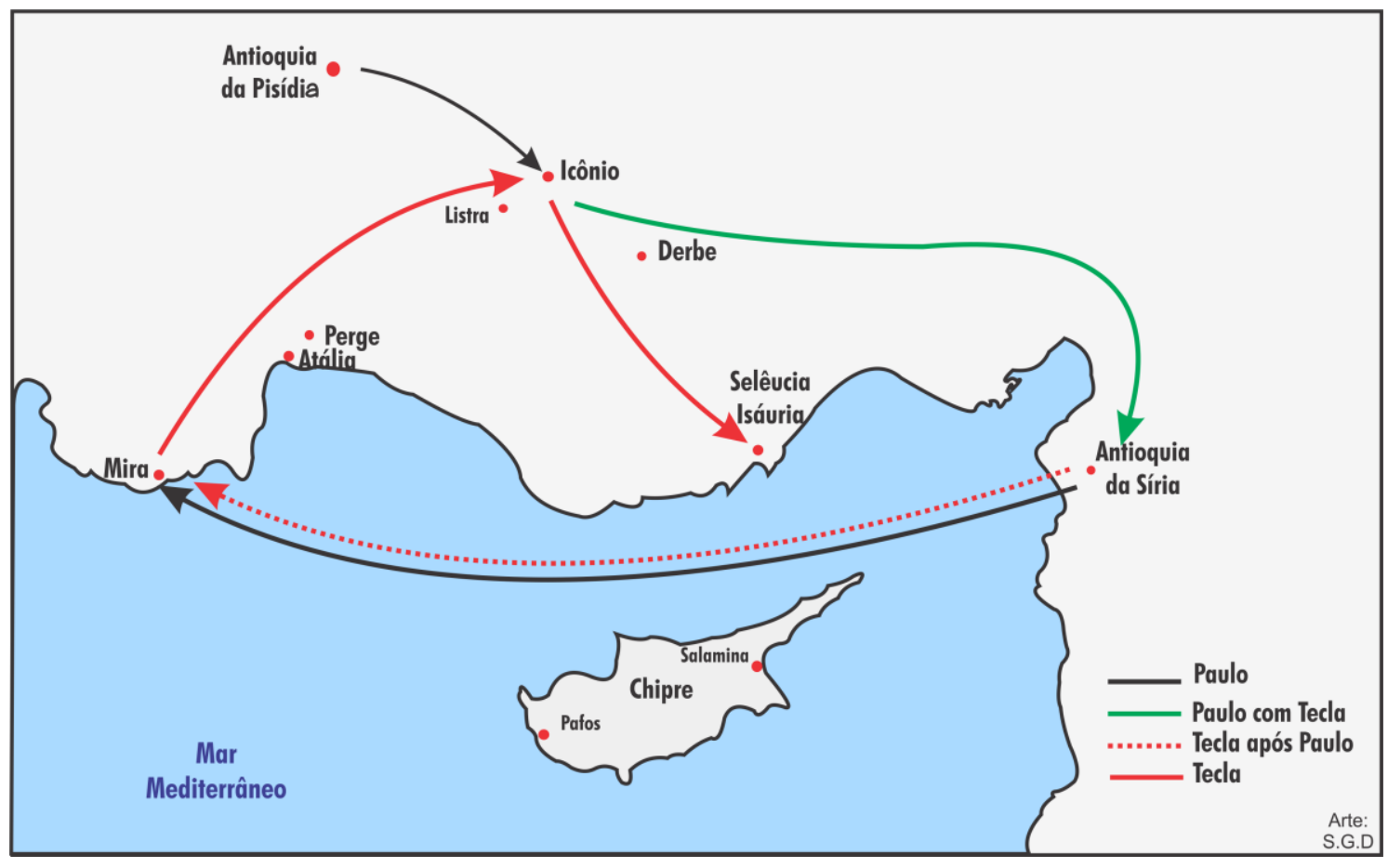

Paulo foge de Antioquia da Pisídia para Icônio e de lá se dirige a Antioquia da Síria, acompanhado de Tecla. Ele desaparece quando Alexandre assedia Tecla e é encontrado por ela, dias depois, em Mira, para onde ele teria ido por mar. De Mira, Tecla se dirige a Icônio e, depois, a Selêucia.

Favorece essa solução o fato de ser coerente com o título de Alexandre (siriarca) e com a menção à estrada real. Contrário a ela é o emprego do verbo inicial da narrativa, anabainonto, que sugere uma viagem que deixa um lugar mais baixo em direção a um mais elevado. Antioquia da Pisídia e Icônio estavam ambas em altitude semelhante. 


\section{Opção 3}

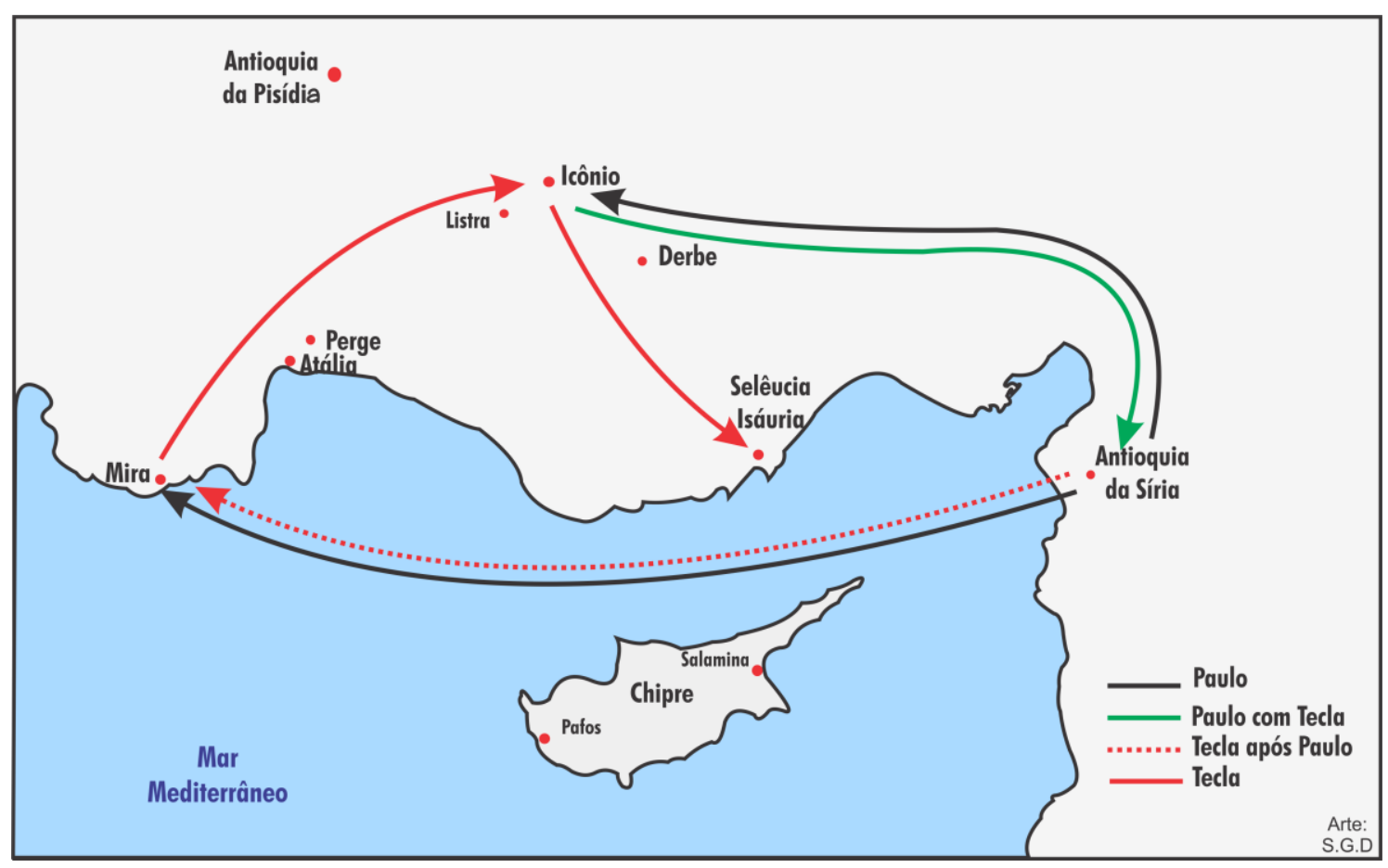

Paulo parte de Antioquia da Síria e volta a ela acompanhado de Tecla. Ele desaparece quando Alexandre assedia Tecla e é encontrado por ela, dias depois, em Mira, para onde ele teria ido por mar. De Mira, Tecla se dirige a Icônio e, depois, a Selêucia.

A favor, o fato de que é coerente com o verbo inicial da narrativa e com o título de Alexandre, o siriarca; porém não condiz com a menção à estrada real ligando as duas cidades. 
Atos de Paulo e Tecla e o relato das viagens de Paulo em Atos dos apóstolos

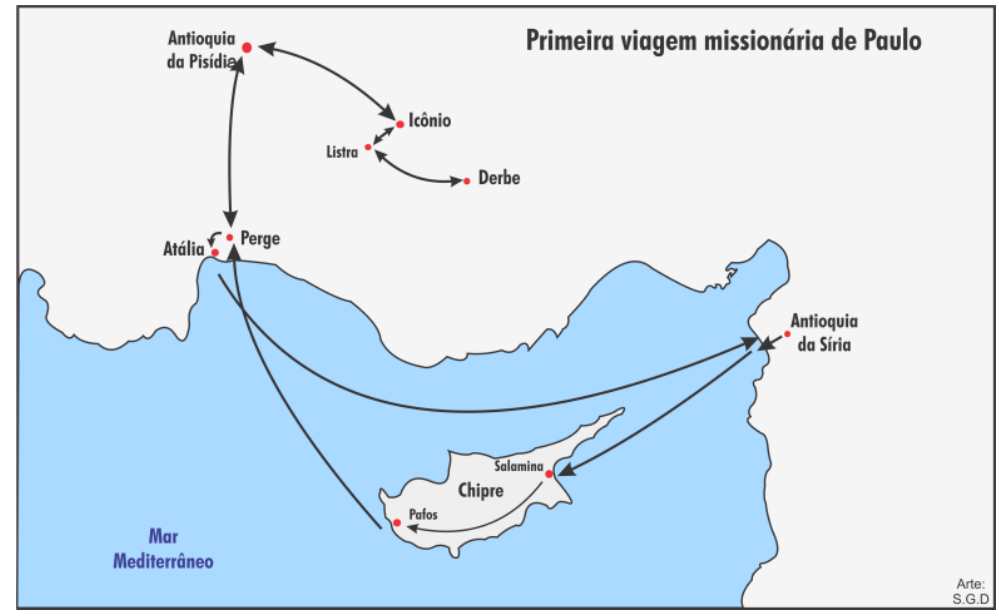

A rota indicada acima é coerente com Atos 13-14, que menciona Paulo fugindo de Antioquia da Pisídia em direção a Icônio. Em seu desfavor, além das incoerências já citadas do trajeto originado em Antioquia da Pisídia, há o de que os outros detalhes desta viagem são muito diferentes da descrição de Atos.
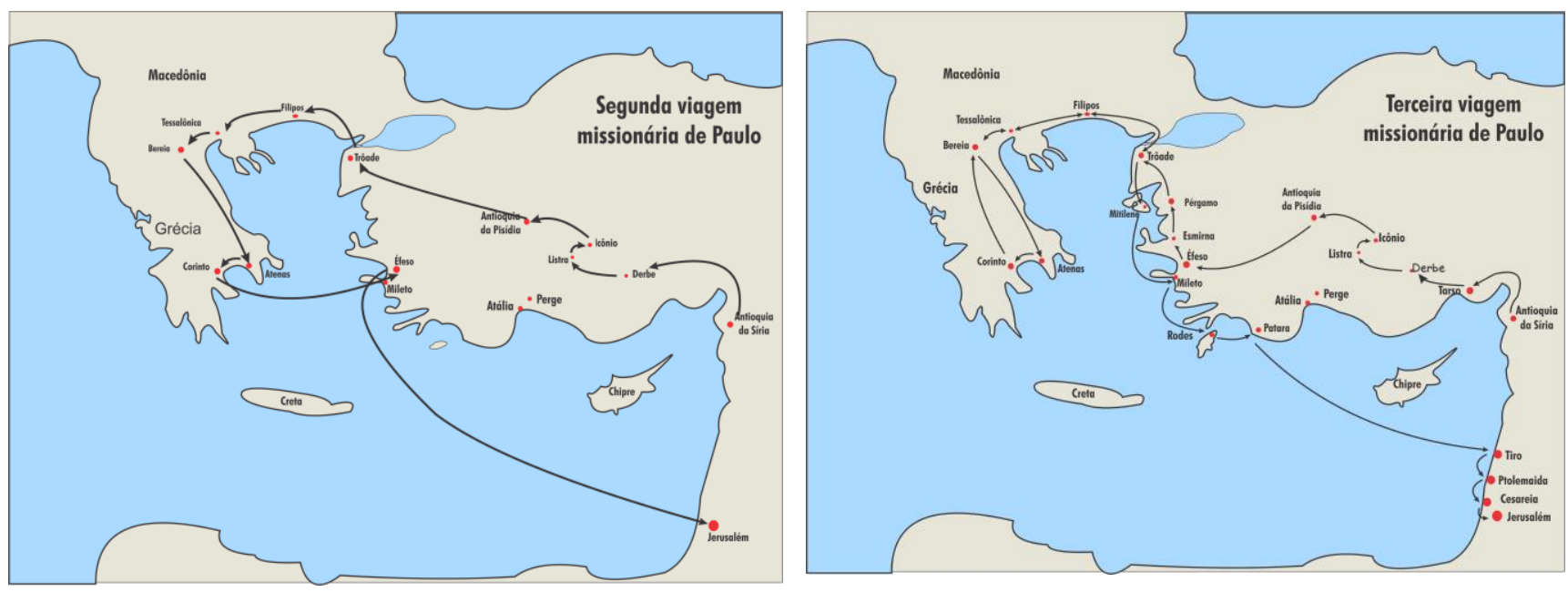

Nas próximas vezes que Atos relata Paulo passando novamente pela região de Icônio, ele está vindo de Antioquia da Síria, o que é coerente com o verbo que descreve Paulo subindo de Antioquia para Icônio. No entanto, nestas duas ocasições não há registro em Atos de perseguições em Icônio e Antioquia, muito menos de uma jovem convertida ao cristianismo chamada Tecla. Assim, o autor de $A P T$ pode ter aproveitado a brevidade do relato lucano para completar a lacuna com sua história. 
Perseguições de Paulo. Atos relata uma perseguição de Paulo em Antioquia da Pisídia e sua consequente fuga, juntamente com Barnabé, para Icônio e desta para Listra (onde foi apedrejado e dado como morto) e Derbe (Atos 13:50 e 51; 14:1-6). Possivelmente seja esse o episódio mencionado em 2 Timóteo 3:11 (ARC): "Perseguições e aflições tais quais me aconteceram em Antioquia, em Icônio, e em Listra; quantas perseguições sofri, e o Senhor de todas me livrou". Em Atos, apesar de tudo isso, partindo de Derbe, Paulo e Barnabé retornam a Listra, Icônio e Antioquia, fortalecendo os novos discípulos e

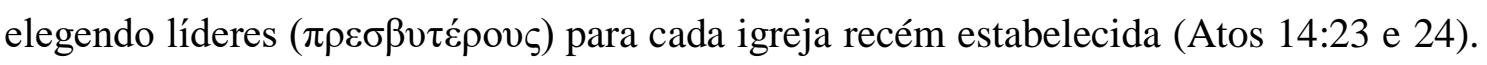
Tudo isso acontece na primeira viagem missionária de Paulo. Atos relata que o apóstolo passou por essa região novamente em sua segunda viagem missionária (Atos 15:40 e 41; 16:1-5) e é possível que tenha transitado por ali também em sua terceira viagem (18:23). Em nenhuma delas relata qualquer indício de perseguição. A ausência de detalhes nestas últimas oferece uma lacuna que pode ter sido aproveitada pelo autor de $A P T$ para a inserção de sua história. É o que defende Vilhauer (2005, p. 253) quando diz que os autores dos AAA "tomam situações conhecidas que são modificadas fundamentalmente (por assim dizer 'transformados em algo diferente')".

Demas e Hermógenes. Os dois companheiros desleais de Paulo possuem nomes ligados à tradição paulina e estão citados nas cartas pastorais. ${ }^{257}$ Pervo $(2014$, p. 89$)$ chama a atenção para a ganância de Demas em APT, o que combina com 2 Timóteo 4:10, que diz: "Demas me desamparou, amando o presente século". E a fama de Hermógenes não é melhor, já que é mencionado entre os que abandonaram o apóstolo (2 Timóteo 1:15). E para "incrementar" a imagem negativa do vilão (ou apenas por confusão), o autor de $A P T$ adiciona "o ferreiro" (ho khalkeús) ao nome dele. Como 2 Timóteo 4:14 se refere a um certo Alexandre, "o ferreiro", que causou muitos males a Paulo, o acréscimo deste ofício a Hermógenes, sinaliza que o autor pode ter se confundido ao tentar estabelecer um vínculo com as pastorais. No entanto, Edsall (2018), propõe que, por serem hábeis na

\footnotetext{
${ }^{257}$ Três cartas neotestamentárias, cujo autor se nomeia Paulo, são conhecidas hoje como pastorais porque apresentam conselhos e admoestações a dois líderes da igreja, para que saibam como exercer o trabalho de pastor. São elas 1 e 2 Timóteo e Tito. Há toda uma polêmica quanto à autoria das pastorais. Para os argumentos contra a autoria autêntica de Paulo, cf. Vielhauer (2005, p. 246 et seq); Hale (1983, p. 235 et seq.). Para aqueles que acreditam na pseudoepigrafia delas, em período posterior à morte de Paulo, surgem ainda outros problemas, devido à grande presença de material das pastorais em $A P$. Várias hipóteses são levantadas para tentar explicar essa relação. Macdonald (1983, p. 76 e 77), acredita que as pastorais, que enfatizam o valor da família e do casamento, "foram escritas para oporem-se à imagem de Paulo nas lendas populares [...] contadas por mulheres para justificar o ministério celibatário delas". Isso explicaria os contrastes doutrinários que, segundo ele, existem entre esses textos. Dunn (2006) discorda, propondo que, em última análise, $A P T$ é basicamente ortodoxo e não transgressor. Uma análise de todos esses pontos de vista mostra-se bastante enriquecedora.
} 
fabricação de ídolos, os artesãos que trabalhavam com metais eram vistos com desconfiança pela comunidade cristã. Após analisar as designações de outros personagens da trama, o pesquisador propõe que a adição de khalkeús tenha sido uma estratégia literária para ampliar a falsidade de Hermógenes (um possível idólatra disfarçado) para o leitor contemporâneo. De qualquer forma, considero que a presença em $A P T$ de nomes citados nas pastorais (cinco ao todo), mais que fonte para a recepção dessas cartas, é uma indicação de que o autor do texto apócrifo procurava estabelecer um vínculo com o universo paulino, em busca de credibilidade ou verossimilhança para sua obra.

O amassem. O autor de APT usou vários termos gregos para designar as afeições de seus personagens, os quais podem ser traduzidos em português por amar: $\alpha \gamma \alpha \pi \alpha ́ \omega$ (seção 1), $\alpha \gamma \alpha ́ \pi \eta$, (seções 17 e 25), $\varphi \imath \lambda \dot{\varepsilon} \omega$ (seções 10, 13 e 27) e, por fim, $\sigma \tau o \rho \gamma \eta \dot{~(s e c ̧ a ̃ o ~ 19) ~ e ~} \sigma \tau \varepsilon \dot{\varepsilon} \rho \gamma \omega$ (seção 29). Na seção 1, $\alpha \gamma \alpha \pi \alpha ́ \alpha \omega$ o tipo de sentimento que Demas e Hermógenes tentavam

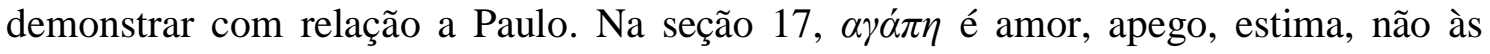
pessoas, mas a uma crença, no caso, “a verdade”. Já na seção 25 , o mesmo vocábulo refere-se ao relacionamento afetuoso que unia o pequeno grupo de cristãos (Paulo, Tecla, Onesíforo e família) e pode também aludir a uma tradicional refeição, compartilhada entre os cristãos, que era denominada pelo mesmo termo. O verbo $\varphi \imath \lambda \varepsilon ́ \omega$ aparece três vezes (seções 10, 13 e 27), todas para descrever os sentimentos dos pretendentes de Tecla para com ela, obviamente aludindo ao amor erótico, que atinge os enamorados, envolvendo atração física. Em contraste, o autor usa $\sigma \tau o \rho \gamma \eta \dot{~(s e c ̧ a ̃ o ~ 19), ~ p a r a ~ s e ~ r e f e r i r ~ a ̀ ~ a f e i c ̧ a ̃ o ~ d e ~}$ Tecla por Paulo. Essa palavra pode ser traduzida por amar, mas indica também uma relação afetiva de ordem distinta, não relacionada ao amor, digamos, erótico, como apresenta $L S J$ (p. 1650): “freq. amor mútuo entre pais e filhos". Embora as atitudes e gestos da jovem para com o apóstolo (alienação semelhante ao $\pi \dot{\alpha} \theta o \varsigma$ É $\rho \omega \tau \iota \kappa o ́ v ~ e n q u a n t o$ o escuta, fuga de casa para encontrá-lo, beijos nas algemas dele) sugiram paixão, parece que o autor quis desfazer a dúvida que ele mesmo criara, indicando através de $\sigma \tau o \rho \gamma \eta ́$ que a afeição de Tecla para com Paulo era diferente da que seus pretendentes sentiam por ela. E a acepção de que essa relação é de outra esfera, que não a da paixão, é reforçada quando

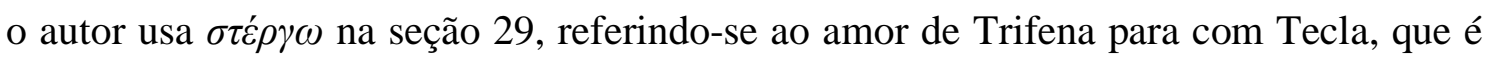
comparado com o da rainha para com sua filha Falconila.

\section{Seção 2}

Onesíforo. Esse personagem também está presente nas cartas pastorais nas quais ele é descrito como hospitaleiro, bondoso e prestativo, cuja família está incluída na passagem 
em que Paulo deseja que "o Senhor conceda misericórdia à casa de Onesíforo, porque, muitas vezes, me deu ânimo e nunca se envergonhou das minhas algemas; antes, tendo ele chegado a Roma, me procurou solicitamente até me encontrar " ( 2 Timóteo 1:16-17, ARA). No entanto, Paulo não menciona Onesíforo em Icônio, apenas em Éfeso: "E tu sabes, melhor do que eu, quantos serviços me prestou ele em Éfeso" (2 Tm 1:18, ARA.). Tanto Pervo (2014, p. 96) quanto Barrier (2008, p. 106, 107) comentam que Onesíforo se tornou um personagem clássico dos AAA, estando presente também nos Atos de Pedro e nos Atos de André.

Tito. Tito foi um importante líder no início da igreja primitiva, um dos companheiros de viagem de Paulo (Gálatas 2:1). Era grego (Gálatas 2:3) e talvez tenha sido convertido à fé cristã pela pregação do apóstolo (Tito 1:4). É também o destinatário de uma das cartas pastorais.

Seção 3.

Estrada Real. É a Via Sebaste, que ligava as colônias romanas, entre elas Antioquia da Pisídia e Icônio. Apesar de ser uma via que realmente existiu, a referência a ela em APT não soluciona as questões geográficas da obra. Para quem entende que Paulo chegou a Icônio vindo de Antioquia da Síria, ela apresenta uma séria dificuldade porque, segundo Pervo, entre as duas cidades não havia estrada real. Para ele, "ou o autor errou ou mesclou tradições incompatíveis" (2014, p. 90) e chama a atenção para o fato de que a tradução siríaca não usa o adjetivo "real", mas apenas o substantivo "estrada".

Aparência de Paulo. A descrição da fisionomia e dos traços corporais de Paulo em APT pode ter influenciado a iconografia do apóstolo nos períodos posteriores. Para uma discussão sobre o assunto, cf. capítulo 2 desta dissertação.

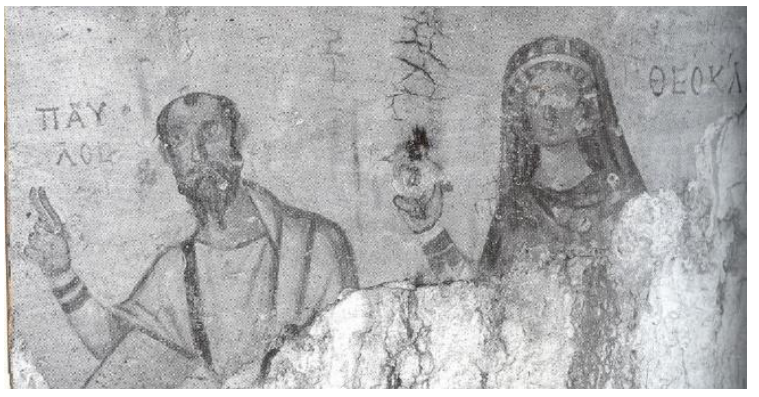

Parte de uma representação artística de $A P T$, provavelmente do século VI, em um sítio arqueológico próximo a Éfeso conhecido como "Grotto of Paul". Na imagem, aparecem Paulo e Teóclia (no afresco completo Tecla está à parte, olhando através de uma janela). Imagem em domínio público. Disponível em < https://commons.wikimedia.org/wiki/File:Paul and Thecla.jpg\#filelinks >

Encratismo. Irineu descreve as crenças encratistas em sua obra Contra Heresias (Adversus Haereses, ca. 180 d.C): “[...] aqueles que são chamados de Encratitas 
(autocontrolados) pregaram contra o casamento, deixando assim de lado a criação original de Deus, e indiretamente culpando Aquele que fez o macho e a fêmea para a propagação da raça humana. Alguns dos que foram contados entre eles também introduziram a abstinência de comida animal, provando-se assim ingratos a Deus, que formou todas as coisas" (IRINEU, Contra Heresias, Livro I, cap. XXVIII, 1). Eusébio de Cesareia (História Eclesiástica, IV.29.5) acrescenta ainda que os encratistas aceitavam partes da Bíblia hebraica e os evangelhos, mas rejeitavam Paulo e suas epístolas e os Atos do Apóstolos. Se essa afirmação for considerada, pode-se levantar a hipótese de que o autor de APT tenha obtido referências orais dos Atos dos Apóstolos, o que justificaria a falta de coerência com o texto canônico. No entanto, é no mínimo intrigante que o encratismo, que segundo Eusébio rejeitava Paulo, seja defendido em uma obra que foi escrita "por amor a Paulo", de acordo com Tertuliano.

Macarismos ou bem-aventuranças. Na literatura grega clássica mákar é um epíteto que assinala o contraste entre o estado dos deuses e o dos homens mortais. Diz Aquiles a Pátroclo a respeito dos mensageiros enviados por Agamênon: "E que sejam eles testemunhas perante os deuses bem-aventurados [theón makáron] e os homens mortais" (Ilíada 1. 338, 339). Apesar de ser uma condição divina, pode ser também conferida a privilegiados mortais, como menciona Príamo com relação a Agamênon: “Ó venturoso [mákar] Atrida, filho do destino, abençoado dos deuses!" (Ilíada 3.182). Ou, ainda, um estado a ser almejado pelos homens, como o que Hécuba desejava que seu neto morto pudesse ter desfrutado, após se tornar adulto, se tivesse se casado e tornado rei, desfrutando poder como os deuses. Então ele seria "venturoso" [makários] (EURÍPIDES, As troianas, v. 1170). A fórmula também está presente em trechos como o da carta XI, $\S$ 3, de Hipócrates (ed. Hereher, 291 apud BERGER, 1998, p. 177): "Felizes (gr. makárioi), porém, são os povos que encaram os homens bons como suas armas, e não as torres nem os muros, e sim as opiniões de homens sábios". No Novo Testamento a palavra grega mantém o sentido de feliz, venturoso. Porém, ocupa um lugar de destaque na elaboração do texto, de acordo com Klaus Berger (1998, p. 177-178), que afirma: "os macarismos tornaram-se instrumentos importantes para a formulação da esperança cristã”. O mesmo autor também especifica algumas das situações típicas em que os macarismos são utilizados: “a) superação de sofrimento e pobreza, b) encorajamento para manter os mais importantes princípios de conduta, c) proclamação da adesão ao cristianismo como valor e felicidade", além de proclamar "a felicidade dos recém-convertidos" [itálicos do autor]. 
Assim, não é difícil perceber a importância dos macarismos no discurso de Paulo, em $A P T$ : não só estabelecem um vínculo estilístico, como se tornam elementos de persuasão. Para um aprofundamento a respeito dos macarismos como forma literária, cf. BERGER, 1998, p. 173-177.

\section{Seção 7}

Tecla ouve o discurso de Paulo. Chama a atenção aqui o fato de o fascínio de Tecla ser provocado pela audição e não pela visão, ao contrário do que acontece com as heroínas dos romances gregos. Além do clássico encontro entre Quéreas e Calírroe, podemos citar o papel do olhar também em Dáfnis e Cloé, dado que a admiração da moça começa quando observa pela primeira vez Dáfnis tomando banho. Da segunda vez, "depois de têlo olhado, ela o tocou e se foi, ainda admirando-o, e sua admiração era um princípio de amor [...] já não tinha vontade de nada, seu coração, já não era dona de seus olhos, [...] não queria mais comer, à noite já não conciliava o sono" (LONGO, I, 13). Brandão (2005, p. 17) contrapondo a maneira grega e judaica de perceber a visão e a audição, comenta que "é proverbial, na Grécia, admitir que o olho pode mais que o ouvido e, por consequência, que o objeto de visão é mais poderoso que a palavra" enquanto que "no pensamento judaico, o que está por trás é o verbo divino, ou seja, o discuso é anterior e mais poderoso que o visível". E Arendt (2000, p. 91) lembra que os judeus adoravam um Deus invisível, que proibia sua representação em imagens, e conclui que a "invisibilidade da verdade é, na religião hebraica, tão axiomática quanto sua inefabilidade na filosofia grega". E acrescenta: "a verdade, entendida em termos de audição, exige obediência". Ora, Tecla ouve o discurso de Paulo, é cativada por ele e obedece-lhe firmemente, uma atitude que reflete as raízes judaicas do cristianismo e sua influência no cristianismo primitivo, quando a veneração de imagens ainda não era uma prática aceitável. Para Pervo (2014, p. 105), tal reversão das convenções do romance abre espaço para uma questão chave: o poder da palavra, a mensagem em maior relevância que o mensageiro. Essa pode ser a explicação para o fato de o páthos erothikón de Tecla ser causado pela audição do discurso de Paulo e não pela visão descrita na seção 3.

Teóclia. A mãe de Tecla entra em cena apresentando uma visão antagônica do ministério de Paulo e representando uma das cenas mais cruéis da obra, quando pede que a filha seja condenada à morte na fogueira. Deste momento em diante ela desaparece da narrativa até a última cena, na qual Tecla se dirige a ela de maneira terna e perdoadora. 


\section{Seção 8}

Tamiris. É um personagem típico dos AAA: um pagão de elevada posição social que se opõe à fé cristã devido, principalmente, ao dano pessoal sofrido pelo fato de sua amada adotar a castidade como estilo de vida, pela conversão à mensagem do apóstolo. Seu papel é necessário ao desenvolvimento da narrativa, já que é o responsável por denunciar Paulo perante as autoridades e iniciar a perseguição no episódio de Icônio. Sánchez (2013, p. 91) recorda que seu nome aparece na Ilíada (II, 591-600), na figura de um aedo trácio, filho do músico Filamon e da ninfa Argíope. Outra relação externa, também mencionada por Sánchez, é que esse nome também aparece em Oratio ad Graecos, 41, 1 e 41, 2), um texto de Taciano, contemporâneo da produção dos AAA e fundador do encratismo, dourina com o qual APT se relaciona.

\section{Seção 14}

Castelio. O governador romano (procônsul, na 16) tem algo de simpático. Ele não é facilmente persuadido por Tamiris que, por sua vez, é instigado por Demas e Hermógenes para acusar Paulo de cristão. Mostrando sua autonomia, Castélio dá oportunidade para que o apóstolo apresente sua defesa e, em seguida, ordena sua prisão, para que possa ouvilo melhor mais tarde. Na seção 21, o narrador relata que ele sofreu muito com o resultado do julgamento de Paulo e Tecla. Também derramou lágrimas quando viu a jovem enfrentar a morte corajosamente. Sánchez (2013) vê nessas passagens uma "humanização do poder romano" que poderia significar uma rápida e sutil sinalização às autoridades imperiais com intenções conciliatórias. Com as perseguições contra os cristãos acontecendo periodicamente (a de Marco Aurélio, de 161-180, sendo muito próxima ou simultânea à composição de $A P T)$, é muito provável que o pesquisador espanhol esteja correto.

Seção 22 .

Sinal da cruz. Ramsay (1893, p. 421) sugere que, tanto nesta passagem quanto na seção 34, Tecla tenha estendido as mãos em atitude de crucifixão e apoia-se em trechos de Tertuliano e Le Blant. O último, por sua vez, menciona Eusébio de Cesareia. Para conferir o argumento de Ramsay, transcrevemos a seguir as passagens dos autores citados. Tertuliano diz: "nós preferimos recomendar nossas orações a Deus adorando com moderação e humildade, sem sequer levantar as mãos muito ao alto, mas erguendo-as de forma suave e adequada" (Tertuliano. De Oratione, XVII). Para Ramsay, isso se devia ao 
desejo dos cristãos de marcarem a diferença entre suas orações e as dos pagãos, os quais as faziam, segundo ele, com as mãos estendidas para o céu. Eusébio, por sua vez, relata o martírio de um jovem que se assemelha bastante ao de Tecla, na seção 34: "Era para ficar atônito ante a intrépida constância daqueles santos em tais circunstâncias e ante a firme e inflexível resistência de seus corpos jovens. Ali pois, verias um jovem, da idade de vinte anos incompletos, de pé, sem correntes e com as mãos estendidas em forma de cruz, que com ânimo impassível e tranqüilo se entregava com a maior calma às orações de Deus, sem mover-se nem desviar-se o mínimo do lugar onde se achava, enquanto ursos e leopardos, respirando furor e morte, quase tocavam já sua carne; mas, não sei como, por uma força inefável e divina, a ponto já de fechar suas mandíbulas, novamente saíam correndo para trás. Assim era este homem” (Eusébio. História Eclesiástica. VIII, vii). Le Blant interpreta esta posição como uma "atitude habitual aos cristãos em oração e na qual eles viam uma imagem, uma lembrança da cruz do Salvador” (1883, p. 297). No NT

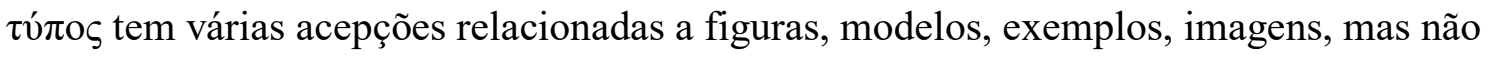
há menção a uma gesticulação em forma de cruz, o que dá a entender que este costume foi adotado posteriormente à era apostólica, como o próprio Ramsay sugere.

\section{Seção 25.}

Selo de Cristo. Ramsay (1893, p. 421) apresenta uma lista de características citadas por Lipsius que provam a antiguidade de $A P T$ e que podem ser divididas em dois grupos. $\mathrm{O}$ primeiro abrange as que pertencem ao século I: "a fórmula simples do batismo em nome de Jesus (seção 34), as formas simples de adoração (dobrar os joelhos, partir o pão, declarar a Palavra de Deus (seção 5) e as reuniões em casas particulares (seções 5 e 7)". O segundo grupo relaciona procedimentos que apontam para o segundo século ou, pelo menos, para formas mais desenvolvidas que as praticadas em meados do primeiro século: por exemplo, oração pelos mortos (seção 29), designação do batismo como 'o selo' (seção 25), a concepção do batismo como uma salvaguarda contra a tentação (seções 25 e 40). Para o arqueólogo escocês, portanto, a seção 25 tem duas características próprias de um estágio do cristianismo mais elaborado que no tempo do próprio apóstolo Paulo.

\section{Seção 26}




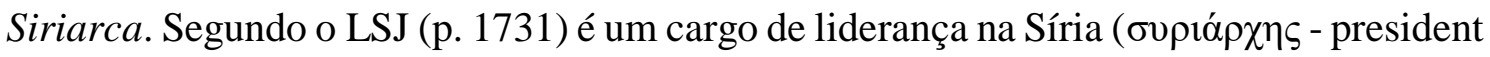
of the provincial council of Syria). Um título como esse, somado ao fato de Alexandre usar uma coroa, dá a entender que ele era um alto funcionário do império (um sacerdote imperial, segundo alguns autores) na cidade de Antioquia da Síria. Essa é a posição de Pervo (2014, p. 151), que designa como "importante" o único manuscrito grego a caracterizar Alexandre assim. Utilizado por Tischendorf e Lipsius (mas não por Kaestli), tal manuscrito, demoninado como $\mathrm{C}$, parece não ser tão importante assim para Schneemelcher (2003, p. 219) que chama a atenção para a superioridade numérica dos

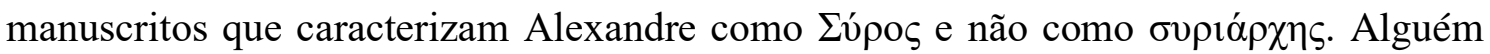
pode utilizar o gentílico como argumento para localizar a cena na Antioquia Síria, mas, como observa Barrier (2008, p. 222), o fato de ele ser sírio não indica necessariamente que esteja na Síria. Ao contrário de "siriarca", que envolve uma autoridade que não faz sentido em Antioquia da Pisídia. Ou seja, é preciso concordar que "a confusão entre as duas cidades é um fato que não podemos resolver a partir do texto" (SÁNCHEZ, 2013, p. 126).

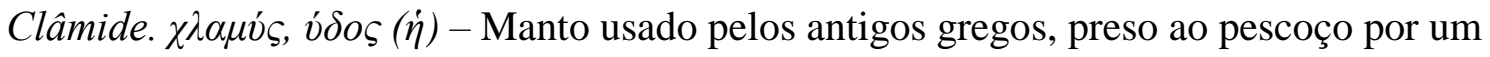
broche $(D G P)$; uma das acepções do Dicionário Grego-português é "capa de comandante, de rei, de nobre, de general". Assim, o manto indica que Alexandre pertence à camada elevada da sociedade. Cf. Department of Greek and Roman Art. "Ancient Greek Dress.” In Heilbrunn Timeline of Art History. New York: The Metropolitan Museum of Art, 2000. Disponível em <https://www.metmuseum.org/toah/hd/grdr/hd_grdr.htm> consultado em 20/12/2018. 


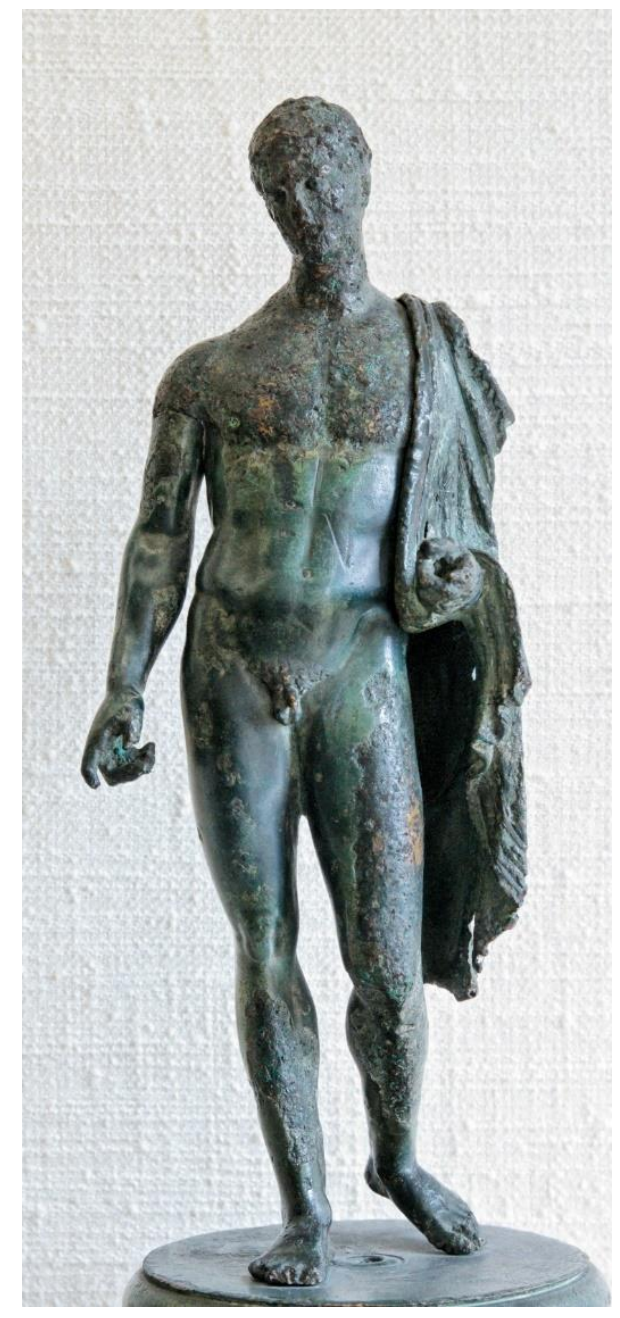

Jovem nu, talvez um Dióscuro ou Mercúrio. Bronze, obra de arte romana, século II d.C. Proveniente da descoberta arqueológica de Sous-Parsat (Auvergne, França), 1824.

Disponível em <

https://en.wikipedia.org/wiki/File:Bronz e youth chlamys Sous-

Parsat_CdM_Paris.jpg\#filehistory > Acesso em 30/01/2019.

Modelo do século XIX em uma recriação da clâmide

Fonte: Wikimedia Commons

Disponível em

https://upload.wikimedia.org/wikipedia/co mmons/4/48/Chlamys.JPG

Acesso em 30/01/2019.

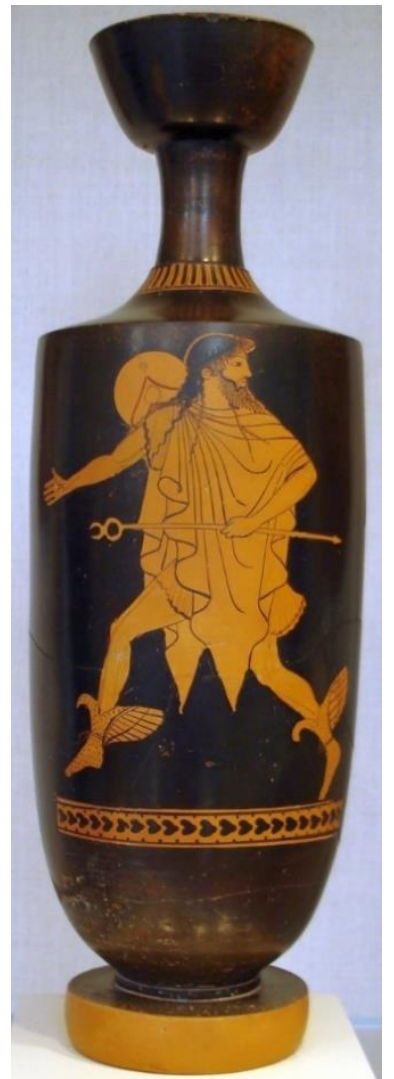

Hermes usando uma clâmide. Vaso grego de cerca de 480-470 a.C.

Fonte: Wiki Commons

Disponível em

https://commons.wikimedia.org/wiki/Fi le:Lekythos of Hermes.jpg. Acesso em 30/01/2019

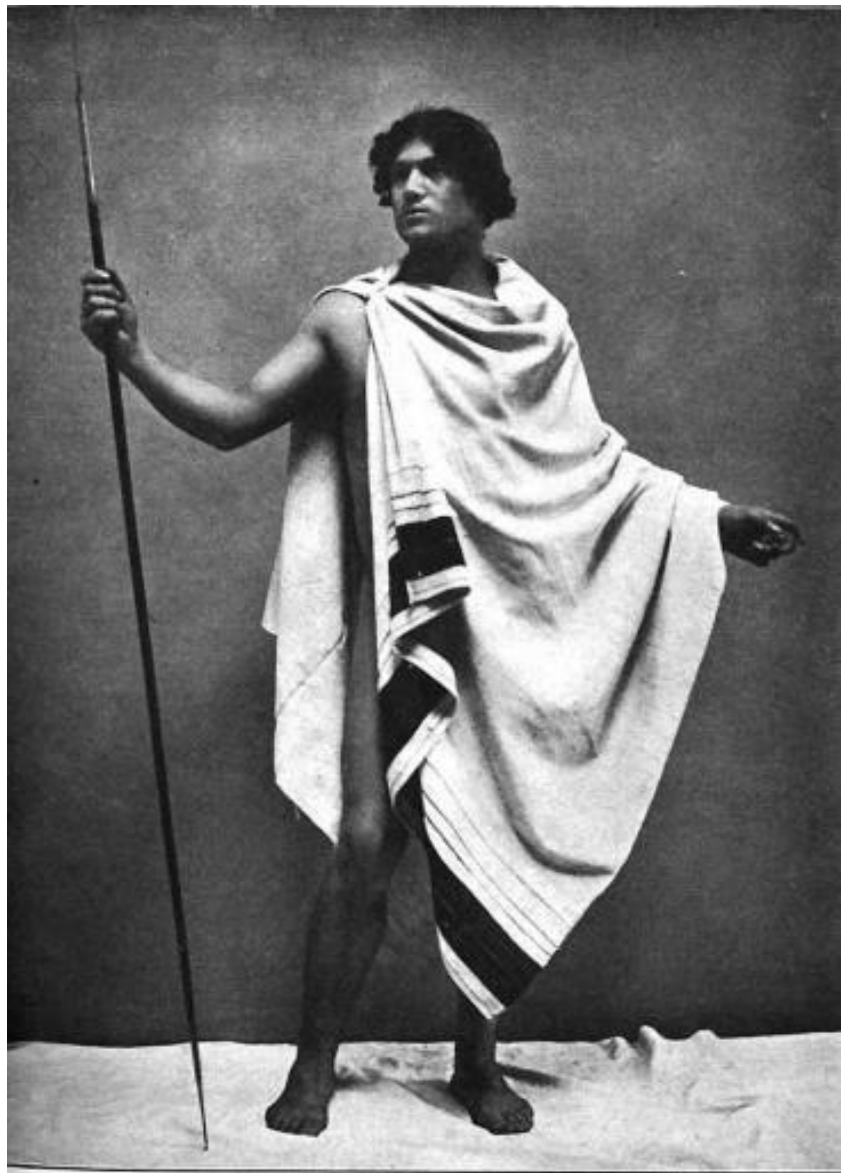

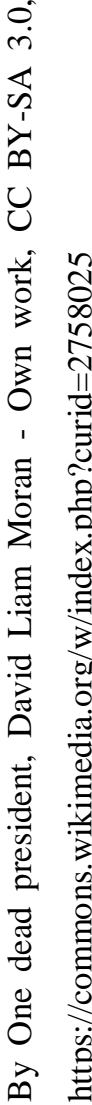

17ig. 64. - PosE DE 1A CHLAMYDE.

D'aprés le modèle vivant. 
Coroa. Segundo Bremmer (1996, p. 50 e 51), as versões siríaca e armênia adicionam que a coroa continha a face de César, indicando que pertencia a um sacerdote imperial, o responsável pela organização dos venatios (lutas com animais selvagens) durante os festivais conectados ao culto imperial. Tal posição sagrada é uma possível explicação para a acusação de "sacrílega", emitida contra Tecla. Para Ramsay (1893, p. 393), "Alexandre, o agonothetes ou presidente deste festival, deve ter sido uma pessoa de grande importância e uma figura de liderança na religião do Estado, a qual era o laço de união e lealdade no Império".

Não agrida a estrangeira. Tecla dá três razões para que Alexandre a deixe em paz. Ela é estrangeira e as convenções da hospitalidade devem ser respeitadas. Ela é uma serva de Deus e, por fim, é uma pessoa da elite que resolveu manter-se casta. Talvez seja uma referência às convenções da hospitalidade aos estrangeiros.

Seção 27

Rainha Trifena. Descobertas arqueológicas mostram que houve uma rainha Trifena, no Ponto. Esse nome também está presente em Romanos 16:12. 


\section{APÊNDICE B}

\section{Paulo, o apóstolo, na literatura neotestamentária}

Paulo, o protagonista de $A P T$, está relacionado com um dos personagens de destaque em Atos dos Apóstolos, a obra que narra as atividades dos discípulos de Jesus no intuito de cumprirem sua ordem de espalhar o evangelho por todo mundo. ${ }^{258}$ Em Atos 22:3 (NVI) somos informados de sua origem e educação: "Sou judeu, nascido em Tarso da Cilícia, mas criado nesta cidade [Jerusalém]. Fui instruído rigorosamente por Gamaliel na lei de nossos antepassados, sendo tão zeloso por Deus quanto qualquer de vocês hoje". Era um cidadão romano por ter nascido em uma província romana, mas seus pais eram judeus e o criaram na fé judaica, da qual era extremamente zeloso. ${ }^{259}$ Educado em Jerusalém, aos pés de Gamaliel, respeitado mestre da lei, Paulo conhecia profundamente todos os meandros da religião de seu povo. Por outro lado, no entanto, estava muito bem familiarizado com a cultura secular de seu tempo, conforme indicam as citações que faz de autores gregos. ${ }^{260} \mathrm{O}$ preparo intelectual de Paulo, não passou despercebido a Festo, que, apesar do tom debochado, reconheceu a erudição do apóstolo (Atos 26:24).

De início ele é Saulo e aparece rapidamente no final do capítulo 7, como responsável por segurar os mantos dos algozes de Estêvão, o primeiro mártir entre os seguidores de Jesus, cuja lapidação ele aprova. Depois, reaparece em Atos 9 como um grande e cruel perseguidor dos discípulos em Jerusalém, dirigindo-se a Damasco para trazer de lá, aprisionados, os membros da seita que conseguiram escapar de suas mãos. No caminho ele tem uma visão gloriosa de Jesus, que se identifica com seus seguidores ao dizer que Saulo o está perseguindo. A luz ofuscante da aparição o deixa cego e o impetuoso perseguidor precisa deixar-se conduzir pelas mãos dos companheiros até Damasco, onde fica por "três dias sem enxergar, sem comer, nem beber" (Atos 9:9 ALM21). Nesse ínterim, Jesus ordena a Ananias, que vá até Paulo e cure suas vistas pela imposição das mãos. Surpreso, o discípulo lembra ao Senhor o perigo que Saulo

\footnotetext{
${ }^{258}$ Cf. Mateus 28:19.

${ }^{259}$ Cf. Gálatas 1:14.

${ }^{260}$ Um exemplo disso é a célebre citação de Menandro (frag $218 \mathrm{~K}$ ), em 1 Coríntios 15:33 "Não se deixem enganar: 'as más companhias corrompem os bons costumes"'. Segundo SILVA (2009, P. 41 e 42), a citação que foi repetida por S. Jerônimo em Epístolas 22. 29, 130.18 e por Tertuliano em À esposa 2. 3. 3, também foi notada por Fócio nos finais do séc. IX nos Amphilochia, 151”. Para outras citações, cf. Rance (2008).
} 
representa e a resposta que recebe norteará o rumo da narrativa subsequente do experseguidor: "Vai, porque ele é para mim um instrumento escolhido para levar o meu nome perante os gentios, reis e israelitas" (Atos 9:15 - ALM21).

Recebida a cura, o Espírito Santo e o batismo, Saulo agora pertence ao grupo que antes odiava e passa a defender zelosamente a crença em Jesus como o Messias enviado por Deus para salvar o mundo do pecado. Não demora muito, os antigos companheiros se tornam cientes de sua mudança radical e da ameaça que, devido a seu caráter destemido e fervoroso, ele representa para a antiga ordem. Em consequência, as forças da perseguição se voltam contra ele e se tornam uma constante durante todo o seu ministério, um fato bem aproveitado em Atos de Paulo. A narrativa sobre o ex-fariseu em Atos é interrompida de 9:32 a 11:25 e de 12:1-25. A partir de 13, o apóstolo assume o papel central até o fim do livro (Atos 28:31). São três longas viagens missionárias, indo de cidade em cidade na Ásia Menor, Galácia, Macedônia e Acaia, implantando novas igrejas e/ou fortalecendo a fé dos irmãos, que a esta altura já eram chamados de cristãos (Atos 11:26). Conhecido mais por seu nome romano, Paulo descreve as vicissitudes e pressões de seu ministério: “Cinco vezes recebi dos judeus trinta e nove açoites. Três vezes fui golpeado com varas, uma vez apedrejado, três vezes sofri naufrágio, passei uma noite e um dia exposto à fúria do mar. Estive continuamente viajando de uma parte a outra, enfrentei perigos nos rios, perigos de assaltantes, perigos dos meus compatriotas, perigos dos gentios; perigos na cidade, perigos no deserto, perigos no mar, e perigos dos falsos irmãos. Trabalhei arduamente; muitas vezes fiquei sem dormir, passei fome e sede, e muitas vezes fiquei em jejum; suportei frio e nudez. Além disso, enfrento diariamente uma pressão interior, a saber, a minha preocupação com todas as igrejas" (2 Coríntios 11:24-28 - NVI).

Além do trabalho pessoal de cidade em cidade, Paulo também escreveu diversas cartas e o NT hoje contém 14 textos atribuídos a ele. Nelas ele mostra sua preocupação com a integridade espiritual dos crentes, enviando orientações, repreensões, conselhos e demonstrações de afeto: "Sentindo, assim, tanta afeição por vocês, decidimos dar-lhes não somente o evangelho de Deus, mas também a nossa própria vida, porque vocês se tornaram muito amados por nós. Irmãos, certamente vocês se lembram do nosso trabalho esgotante e da nossa fadiga; trabalhamos noite e dia para não sermos pesados a ninguém, enquanto lhes pregávamos o evangelho de Deus" (1 Tessalonicenses 2:8,9 - NVI). Tanto empenho resultou na disseminação dos ensinos de Cristo por uma enorme área do império romano e o tornou uma personalidade muito amado entre os cristãos. 
Os últimos capítulos de Atos narram a trajetória de sua viagem a Roma, levado como prisioneiro desde Jerusalém. Mas o livro termina sem encerrar a história de sua vida. As informações do final dela vêm de algumas de suas cartas, da tradição e da patrística. Ele teria sido preso e condenado à morte por Nero, deixando para a igreja cristã um legado que transcendeu seu tempo e encontra repercussão até os dias atuais.

Um dos textos mais conhecidos e celebrados de sua produção, um exemplo da grande capacidade expressiva de Paulo, é conhecido como o "Hino ao Amor" e toca em questões da essência do ser humano, despertando reflexões poderosas a respeito do que realmente é importante, qualquer que seja a visão de mundo de seu leitor. Creio que vale reproduzi-lo integralmente, embora seja longo (1 Coríntios 13:1-13 - NVI):

Ainda que eu fale as línguas dos homens e dos anjos, se não tiver amor, serei como o sino que ressoa ou como o prato que retine.

Ainda que eu tenha o dom de profecia e saiba todos os mistérios e todo o conhecimento, e tenha uma fé capaz de mover montanhas, mas não tiver amor, nada serei.

Ainda que eu dê aos pobres tudo o que possuo e entregue o meu corpo para ser queimado, mas não tiver amor, nada disso me valerá.

O amor é paciente, o amor é bondoso. Não inveja, não se vangloria, não se orgulha.

Não maltrata, não procura seus interesses, não se ira facilmente, não guarda rancor.

O amor não se alegra com a injustiça, mas se alegra com a verdade.

Tudo sofre, tudo crê, tudo espera, tudo suporta.

O amor nunca perece; mas as profecias desaparecerão, as línguas cessarão, o conhecimento passará.

Pois em parte conhecemos e em parte profetizamos;

quando, porém, vier o que é perfeito, o que é imperfeito desaparecerá.

Quando eu era menino, falava como menino, pensava como menino e raciocinava como menino. Quando me tornei homem, deixei para trás as coisas de menino.

Agora, pois, vemos apenas um reflexo obscuro, como em espelho; mas, então, veremos face a face. Agora conheço em parte; então, conhecerei plenamente, da mesma forma como sou plenamente conhecido.

Assim, permanecem agora estes três: a fé, a esperança e o amor. O maior deles, porém, é o amor. 